-VIVERSII. VI

LLINOIS I BRARY

UREAN HAMPAIGN

AGRILULTURE 

.630 .7

El 6 b

no. 768

c. 8
Corn Movements

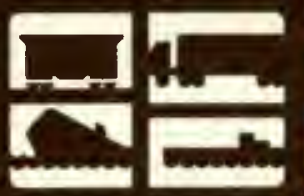

\section{in the United States}

Interregional Flow Patterns

and Transportation Requirements in 1977

Lowell D. Hill, Mack N. Leath, and Stephen W. Fuller

$+2$

\section{1}

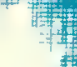

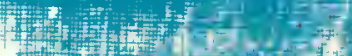

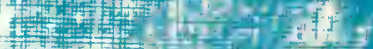

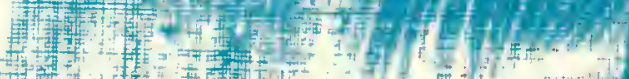
a $x_{0}$

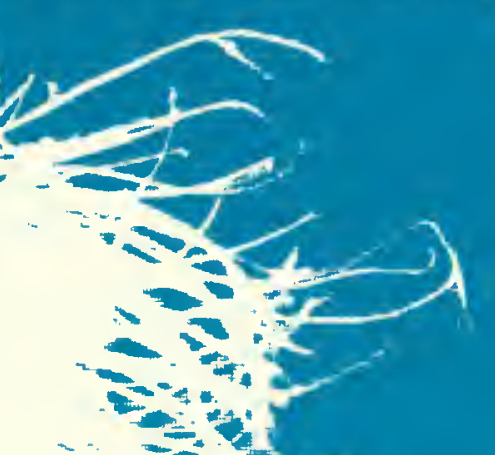

. 


\begin{abstract}
The marketing of corn in the U.S. involves complex interregional grain movements. Moving the crop from the area of concentrated production to points where it is used or exported requires a large transportation capacity. To provide a basis for policy and investment decisions, detailed information on corn movements during 1977 was collected from 3,500 grain merchandising, processing, and exporting firms in 41 states. Survey data on receipts and shipments for each state or substate area were expanded to represent total volumes for those areas and were verified by comparison with information from secondary sources. The data, which represent the most comprehensive and accurate information available on corn movements, are presented and summarized in this bulletin.
\end{abstract}

Keywords: Grain flows, grain shipping, grain transportation, interregional analysis, corn, corn marketing 


\section{Corn Movements}

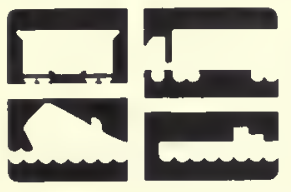

\section{in the United States \\ Interregional Flow Patterns and Transportation Requirements in 1977}

Lowell D. Hill, L. J. Norton Professor of Marketing, Department of Agricultural Economics, University of Illinois at Urbana-Champaign

Mack N. Leath, Agricultural Economist, Economics and Statistics Service, U. S. Department of Agriculture

Stephen W. Fuller, Associate Professor, Department of Agricultural Economics, Texas A\&M University

North Central Regional Research Bulletin 275

Southern Cooperative Series 253

Illinois Bulletin 768
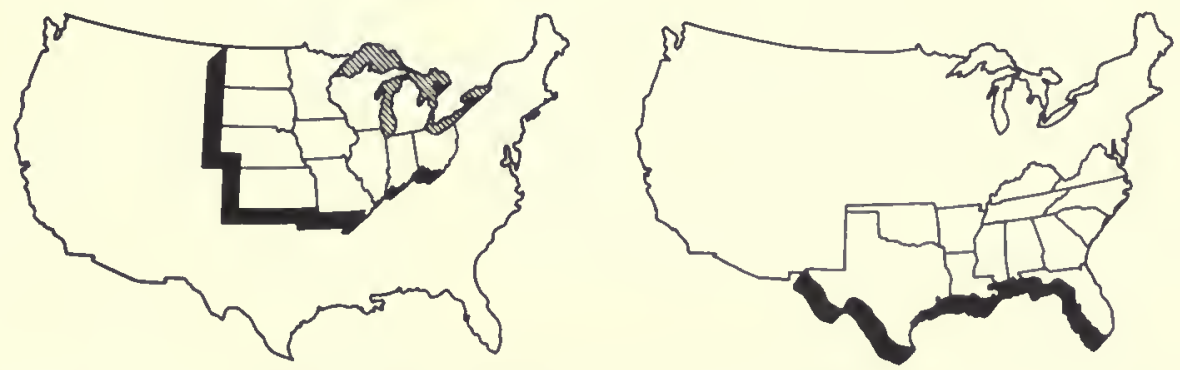

Agricultural Experiment Stations of Alabama, Arkansas, California, Georgia, Idaho, Illinois, Indiana, lowa, Kansas, Kentucky, Louisiana, Michigan, Minnesota, Mississippi, Missouri, Montana, Nebraska, North Dakota, Ohio, Oklahoma, Oregon, South Dakota, Tennessee, Texas, Wisconsin, and the United States Department of Agriculture cooperating.

The participating agricultural experiment stations and government agencies provide equal opportunities in programs and employment.

January 1981 
This publication is sponsored by the Agricultural Experiment Stations of the following states, by the Science and Education Administration - Cooperative Research (SEA-CR), U.S. Department of Agriculture (USDA), and by the Economics and Statistics Service (ESS), USDA.

\begin{tabular}{ll}
$\begin{array}{l}\text { Participating } \\
\text { state }\end{array}$ & \multicolumn{1}{c}{ Experiment station } \\
Alabama & G. A. Buchanan \\
Arkansas & L. O. Warren \\
California & J. B. Kendrick, Jr. \\
Georgia & W. P. Flatt \\
Idaho & R. J. Miller \\
Illinois & R. G. Cragle \\
Indiana & B. R. Baumgardt \\
Iowa & L. R. Kolmer \\
Kansas & F. W. Smith \\
Kentucky & C. E. Barnhart \\
Louisiana & D. Chambers \\
Michigan & S. H. Wittwer \\
Minnesota & R. J. Sauer \\
Mississippi & R. R. Foil \\
Missouri & A. M. Lennon \\
Montana & J. R. Welsh \\
Nebraska & R. G. Amold \\
North Dakota & H. R. Lund \\
Ohio & R. M. Kottman \\
Oklahoma & C. B. Browning \\
Oregon & J. R. Davis \\
South Dakota & R. A. Moore \\
Tennessee & D. M. Gossett \\
Texas & N. P. Clarke \\
Wisconsin & L. M. Walsh \\
&
\end{tabular}

This publication reports the results of research conducted by three regional technical committees: Southern Regional Committee S-115 on Alternative Structures for Increasing Efficiency in Intra- and Inter-regional Grain Marketing Systems; North Central Regional Committee NC-137 on Evaluation of Alternative Rural Freight Transportation, Storage, and Distribution Systems, and North Central Regional Committee NC-139 on Economic Analysis of the U.S. Grain Exporting System. The following state Agricultural Experiment Station representatives, Tennessee Valley Authority (TVA) staff members, and U.S. Department of Agriculture personnel comprised the technical committees.

\section{SOUTHERN REGIONAL COMMITTEE S-115}

\footnotetext{
Alabama - J. L. Stallings*

Arkansas - W. R. Morrison, E. J. Wailes*

Georgia - R. F. Anderson,* M. R. Holmes

Illinois - L. D. Hill*

Indiana - B. F. Jones

Kentucky - M. R. Reed, D. M. Shuffett*

Louisiana - N. C. Clark, H. D. Traylor

Mississippi - W. L. Bateman, ${ }^{*}$ T. D. Phillips

Ohio - E. D. Baldwin, J. W. Sharp*

Tennessee - C. B. Sappington*

TVA - W. J. Free, ${ }^{*}$ L. E. Stone

ESS, USDA - T. Q. Hutchinson,* M. N. Leath*
}

SEA - CR, USDA - L. C. Halvorson

Administrative Adviser - T. J. Whatley (Tennessee)

NORTH CENTRAL REGIONAL COMMITTEE NC-137

Illinois - L. D. Hill*

Indiana $-\mathrm{J}$. K. Binkley*

Iowa - C. P. Baumel*

Kansas - L. O. Sorenson*

Michigan - S. R. Thompson*

Minnesota - R. P. Dahl*

Missouri - R. K. Rudel*

Montana - W. W. Koo*

Nebraska - D. G. Anderson*

North Dakota - D. W. Cobia*

Ohio - D. W. Larson*

Oklahoma - M. A. Johnson, R. L. Oehrtman*

South Dakota - C. E. Lamberton*

Texas - S. W. Fuller*

Wisconsin - R. H. Vilstrup*

ESS, USDA - L. A. Hoffman,* L. D. Schnake, D. L. Watt SEA - CR, USDA - L. C. Halvorson

Administrative Adviser - D. E. Anderson (North Dakota)

NORTH CENTRAL REGIONAL COMMITTEE NC-139

California - A. F. McCalla*
Idaho-J. R. Jones*
Illinois - L. D. Hill*
Indiana - B. F. Jones*
Iowa - G. W. Ladd*
Kansas - L. W. Schruben*
Minnesota - R. P. Dahl*
Missouri - R. K. Rudel*
Montana - G. L. Cramer*
Nebraska - D. A. Linsenmeyer*
North Dakota - D. E. Anderson, W. W. Wilson*
Ohio- J. W. Sharp*
Oklahoma - R. L. Oehrtman*
Oregon - M. V. Martin*
South Dakota - A. C. Sogn
Texas - M. L. Cook*
ESS, USDA - A. R. Bunker, R. E. Friend, C. B. Han-
$\quad$ rahan,* B. H. Wright*

Federal Grain Inspection Service, USDA - F. F. Niernberger

SEA - CR, USDA - L. C. Halvorson

Administrative Adviser - H. J. Schweitzer (Illinois)

The following state Agricultural Experiment Station personnel also cooperated in the research:
Arizona - T. F. Archer
Colorado - W. T. Spencer
Connecticut - S. K. Seaver
Florida - J. K. Dow
Maine - D. D. Harlan
Maryland - J. L. Crothers
New York - M. E. Brunk
North Carolina - T. E.
Pennsylvania - S. K. Abshire
H. L. Moore
South Carolina - S. E. Miller
Utah $-\mathrm{R}$. H. Anderson
Vermont - N. T. Power
Virginia - D. E. Kenyon
Washington - K. L. Casavant
Wyoming - J. S. St. Clair Nichols

\footnotetext{
- Voting member and project leader for the participating organization.
} 


\section{Preface}

The research reported in this bulletin is the first effort ever made to survey grain shippers and receivers nationwide; it is the most comprehensive study of grain movements ever conducted. Members of the technical committees, including representatives of Agricultural Experiment Stations in 25 states, assisted in conducting an industry survey to collect flow data for wheat, corn, soybeans, sorghum, oats, barley, and rye. In addition, surveys were conducted in 16 other states through contracts with 15 universities located in those states. The industry surveys were coordinated by Lowell D. Hill, Department of Agricultural Economics, University of Illino is at Urbana-Champaign. The data were tabulated and summarized under the supervision of Mack N. Leath, Economics and Statistics Service, U.S. Department of Agriculture. The success of this research project is due to the cooperation of thousands of grain marketing firms and the efforts of researchers in the many participating states.

The research was funded in part through contract DACW 72-78-C-0005 with the Institute of Water Resources, U.S. Army Corps of Engineers. Supplemental support was provided by the Federal Railroad Administration of the U.S. Department of Transportation, the Maritime Administration of the U.S. Department of Commerce, and the St. Lawrence Seaway Development Corporation. Administration of grant funds was coordinated by Lowell D. Hill, University of Illinois at Urbana-Champaign.

\section{Contents}

Introduction $\ldots \ldots \ldots \ldots \ldots \ldots \ldots \ldots \ldots \ldots \ldots \ldots \ldots \ldots \ldots \ldots \ldots \ldots$

Purpose of Study $\ldots \ldots \ldots \ldots \ldots \ldots \ldots \ldots \ldots \ldots \ldots \ldots \ldots \ldots \ldots \ldots$

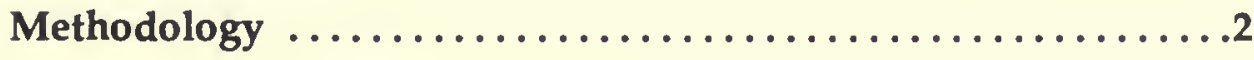

Verification of Data $\ldots \ldots \ldots \ldots \ldots \ldots \ldots \ldots \ldots \ldots \ldots \ldots$

Overview of Movements .......................

Receipts and Shipments by Area $\ldots \ldots \ldots \ldots \ldots \ldots \ldots \ldots$ 


\section{Tables}

1. Production, Farm Use, and Sales by State for the 1977 Corn Crop . . . . . . . . . . . . . 2

2. Corn Supply and Disappearance in the United States for Marketing Years

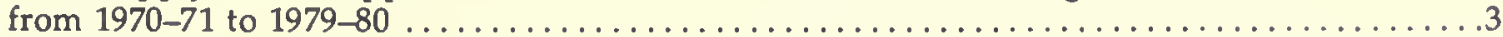

3. Export Regions, Port Areas, and the Ports Included in Each Area ................. 5

4. Comparison of 1977 Corn Receipts, Shipments, and Inspections for Export at Various

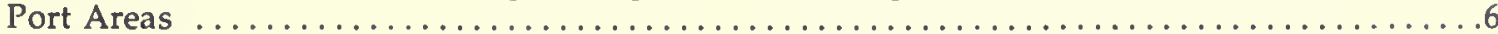

5. Comparison of 1977 Waterway Movements of Corn in the U.S. as Reported by Survey Respondents and the U.S. Army Corps of Engineers ..........................

6. Comparison of 1977 Rail Movements of Corn as Reported by Survey Respondents and as

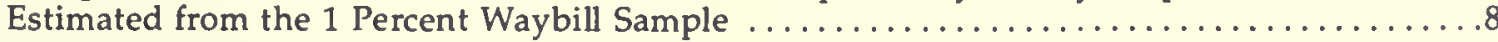

7. 1977 Intrastate Shipments of Corn for Each State and Mode of Transportation . . . . . . . . 11

8. 1977 Interstate Shipments of Corn for Each State and Mode of Transportation . . . . . . . . 12

9. 1977 Interstate Receipts of Corn for Each State and Mode of Transportation ............13

10. 1977 Movements of Corn to Points of Export from Each Originating State by Three

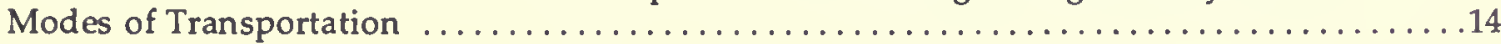

11. 1977 Receipts of Corn at Port Areas by Each Mode of Transportation ...............15

12. 1977 Exports of U.S. Corn from Canada and the United States by Coastal Area and Destination

13-

204. 1977 Corn Receipts (Shipments) by Substate Area . . . . . . . . . . . . . . . . . 20

205-

229. 1977 Corn Receipts (Shipments) by Port Areas

\section{Figures}

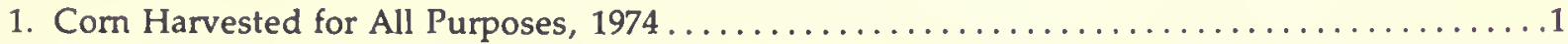

2. Location of Grain Flow Study Regions . . . . . . . . . . . . . . . . . . . . . . .4

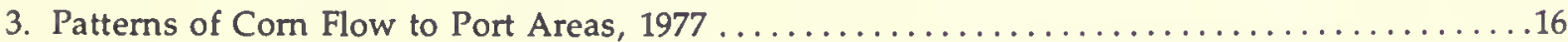

4. Proportion of 1977 Corn Movements to Export Regions from Each Originating State . . . . . . 17 



\section{Corn Movements In The United States}

\section{Interregional Flow Patterns and Transportation Requirements in 1977}

\section{INTRODUCTION}

Information about the origin and destination of grain produced in the United States and about the modes of transportation used to convey it is important for many policy and investment decisions. Although data on the quantities of grains shipped abroad for each port are available and statistics on the amount of grain shipped on inland waterways are published annually, little information has been available that could be used to match origins with destinations and to identify the mode of transportation used.

Through personal interviews with over 3,500 grain merchandisers, processors, and exporters through- out the United States, data on origins, destinations, and transport modes have now been assembled for corn, wheat, soybeans, sorghum, oats, barley, and rye. This publication summarizes the data for corn. Other publications in this series provide similar information for the other grains.

The large volume of corn that must be transported is the result of a highly concentrated production area and a large export demand channeled primarily through two major port areas. As shown in Figure 1 , the production of corn is concentrated in the eight states of Illinois, Indiana, Iowa, Ohio, Minnesota, Michigan, Nebraska, and Wisconsin. In 1977 these states accounted for 78 percent of the total U.S. corn production of over 6 billion bushels. Nearly 60 percent of that total entered commercial market

FIgure 1. Corn harvested for all purposes, 1974.

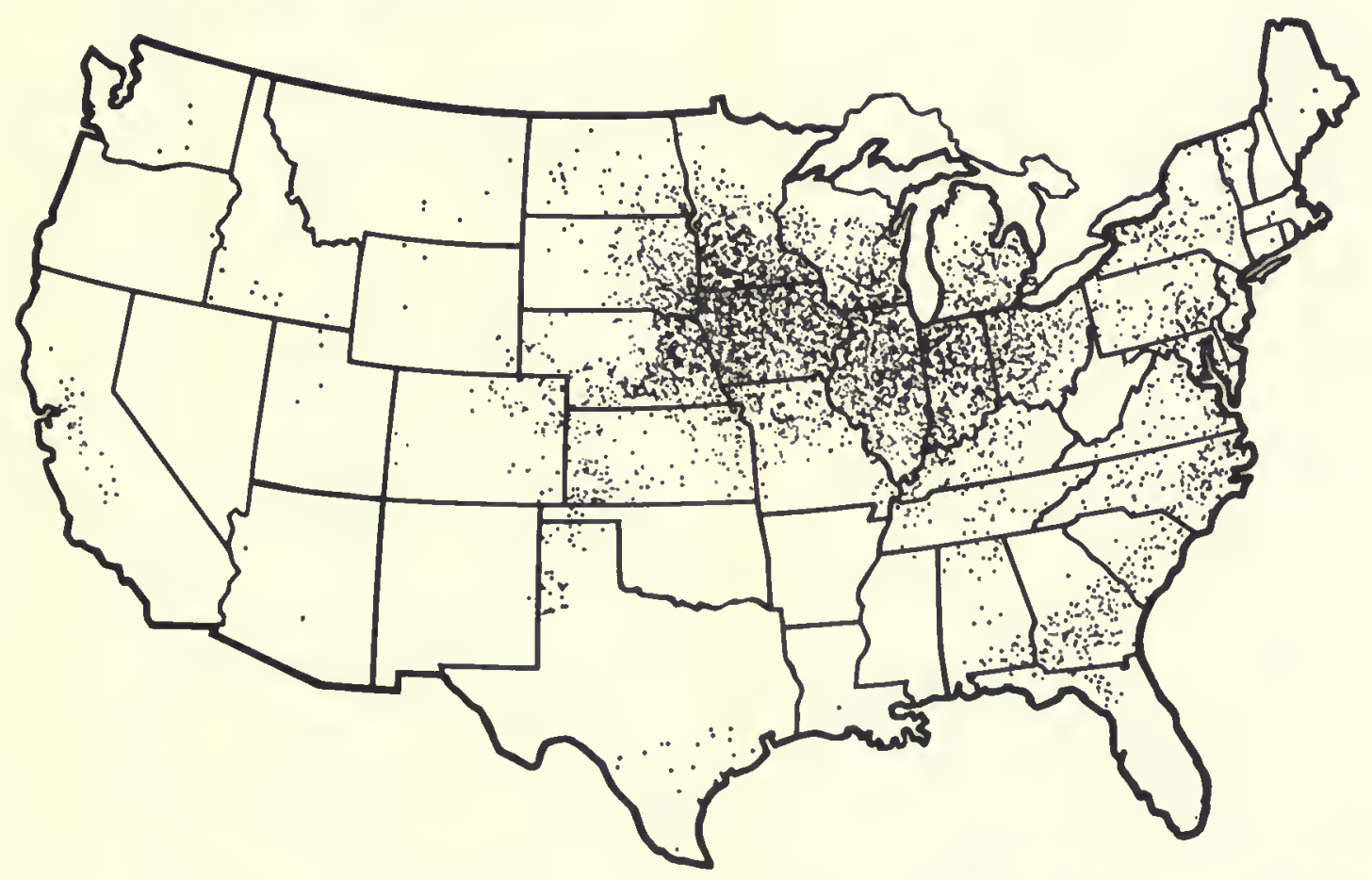


channels and required some form of transportation (Table 1).

Corn is widely used as an animal feed and, to a lesser extent, for human consumption, for industrial products such as starch and alcohol, and for seed (Table 2). The proportion of total production used for livestock feed has declined from 86 percent in $1970-71$ to 56 percent in 1979-80. This decline has been offset by a 364 percent increase in exports and a 55 percent (218-million-bushel) increase in food and industrial use. One effect of these changes, especially the increase in exports, has been an increased demand for transportation and marketing services. These changes in demand influence the destination and mode of transportation selected by the shippers.

\section{PURPOSE OF STUDY}

Analysis of grain flow patterns can reveal the geographical nature of grain markets and the types of transportation services required by the grain industry. This information is useful to grain firms in identifying additional marketing opportunities and in making decisions about where to locate new handling, storage, and processing facilities. Of equal importance is the value of this information to those who set federal and state transportation policies. The formulation of rational grain transportation policies depends upon knowledge of existing grain flows and associated transportation modes. In many situations, firms or public agencies make decisions affecting the production, storage, and transportation of grain without adequate information about grain distribution patterns and the demands that those decisions will place on the various transportation modes. The objectives of this study were:

1. To determine the volume of corn moving between various origins and destinations

2. To determine the extent to which the various transportation modes are employed in the movement of corn in the U.S.

\section{METHODOLOGY}

For the purpose of this study, the United States was divided into 132 numbered regions and 31 ports, as shown in Figure 2. Data for the 31 ports were aggregated into 13 port areas located in four major export regions. The specific ports included in each port area are listed with their identifying numbers in Table 3. Corn flow data were collected for the 1977 calendar year primarily through personal interviews with representatives of grain handling, storage, and processing firms in 41 states. The firms from which data were obtained included country elevators, inland terminal elevators, river terminal

Table 1. Production, Farm Use, and Sales by State for the 1977 Corn Crop

\begin{tabular}{|c|c|c|c|}
\hline State & $\begin{array}{c}\text { Corn } \\
\text { produced }\end{array}$ & $\begin{array}{l}\text { Amount used on } \\
\text { farms where } \\
\text { produced }\end{array}$ & $\begin{array}{l}\text { Amount } \\
\text { sold }\end{array}$ \\
\hline \multirow{6}{*}{$\begin{array}{l}\text { Alabama ......... } \\
\text { Arizona ......... } \\
\text { Arkansas ......... } \\
\text { California ........ } \\
\text { Colorado ........ }\end{array}$} & \multicolumn{3}{|c|}{ thousands of bushels } \\
\hline & 10,875 & 5,872 & 5,003 \\
\hline & 5,000 & 250 & 4,750 \\
\hline & 2,279 & 1,527 & 752 \\
\hline & 28,652 & & 26,646 \\
\hline & 80,620 & 13,705 & \\
\hline \multirow{4}{*}{$\begin{array}{l}\text { Delaware } \ldots \ldots \ldots \ldots \\
\text { Florida } . . . \ldots \ldots \ldots \\
\text { Georgia } \ldots \ldots \ldots \ldots \\
\text { Idaho } \ldots \ldots \ldots \ldots \ldots\end{array}$} & 10,3 & & 7,252 \\
\hline & 10,465 & 5,4 & 5,023 \\
\hline & 24,000 & & 12,720 \\
\hline & 2,408 & & 1,613 \\
\hline \multicolumn{2}{|c|}{ Illinois . . . . . . . . 1,163,400 } & 325,752 & 837,648 \\
\hline \multirow{5}{*}{ 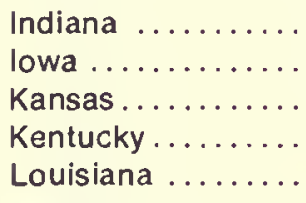 } & . 633,420 & & \\
\hline & $.1,092,200$ & 535,178 & 557,022 \\
\hline & & & 111,283 \\
\hline & 132 & & 057 \\
\hline & 3,380 & & 946 \\
\hline \multirow{5}{*}{$\begin{array}{l}\text { Maryland ......... } \\
\text { Michigan ......... } \\
\text { Minnesota ....... } \\
\text { Mississippi . . . . . } \\
\text { Missouri ........ }\end{array}$} & & & 080 \\
\hline & 197,200 & & 906 \\
\hline & 600,000 & & 324,000 \\
\hline & 5,760 & & 806 \\
\hline & 201,400 & 116,812 & 84,588 \\
\hline \multirow{5}{*}{$\begin{array}{l}\text { Montana ......... } \\
\text { Nebraska ........ } \\
\text { New Jersey ....... } \\
\text { New Mexico ....... } \\
\text { New York ........ }\end{array}$} & & & 165 \\
\hline & 648,450 & 233, & 415,008 \\
\hline & 6,650 & & 4,655 \\
\hline & & & 9,029 \\
\hline & & & 22,016 \\
\hline \multirow{5}{*}{ 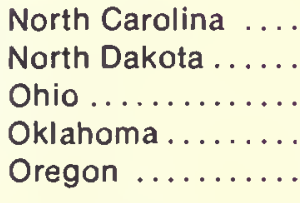 } & & & 794 \\
\hline & & & 073 \\
\hline & 380,10 & 136,8 & 243,264 \\
\hline & & & 4,986 \\
\hline & & & 627 \\
\hline \multirow{5}{*}{$\begin{array}{l}\text { Pennsylvania ...... } \\
\text { South Carolina .... } \\
\text { South Dakota .... } \\
\text { Tennessee ....... } \\
\text { Texas ........... }\end{array}$} & 106 & & 43,755 \\
\hline & & & 17,885 \\
\hline & 126,850 & 67,2 & 59,620 \\
\hline & & & 21,827 \\
\hline & 161,700 & 27,48 & 134,211 \\
\hline Utah ............ & & & 764 \\
\hline Virginia .......... & 30,800 & 16,324 & 14,476 \\
\hline \multirow{2}{*}{$\begin{array}{l}\text { Washington ....... } \\
\text { West Virginia ..... }\end{array}$} & 7,616 & & 6,474 \\
\hline & 3,996 & 3,357 & 639 \\
\hline Wisconsin ........ & 291,200 & 165,984 & 125,216 \\
\hline Wyoming ........ & 2,550 & 1,530 & 1,020 \\
\hline U.S. total ...... & 5,457 & $2,514,027$ & $3,911,430$ \\
\hline
\end{tabular}

Source: Field Crops: Production, Disposition, Value, 1977-1978, Economics and Statistics Service, U.S. Department of Agriculture, $\operatorname{CrPr} 1$ (79) (April 11, 1979), p. 6. 
Table 2. Corn Supply and Disappearance In the Unlted States for Marketing Years from 1970-71 to 1979-80

\begin{tabular}{|c|c|c|c|c|c|c|c|c|}
\hline \multirow[b]{2}{*}{$\begin{array}{l}\text { Marketing } \\
\text { year }\end{array}$} & \multicolumn{4}{|c|}{ Supply } & \multicolumn{4}{|c|}{ Disappearance } \\
\hline & $\begin{array}{l}\text { Beginning } \\
\text { stocks }\end{array}$ & $\begin{array}{l}\text { Produc- } \\
\text { tion }\end{array}$ & Imports & Total & $\begin{array}{l}\text { Food, } \\
\text { seed, and } \\
\text { alcohol }\end{array}$ & Feed & Exports & Total \\
\hline & \multicolumn{8}{|c|}{ millions of bushels } \\
\hline $1970-71 \ldots \ldots \ldots$ & 1,005 & 4,152 & 4 & 5,161 & 396 & 3,581 & 517 & 4,494 \\
\hline $1971-72 \ldots \ldots \ldots \ldots$ & 667 & 5,641 & 1 & 6,309 & 409 & 3,978 & 796 & 5,183 \\
\hline $1972-73 \ldots \ldots \ldots \ldots$ & 1,126 & 5,573 & 1 & 6,700 & 423 & 4,310 & 1,258 & 5,991 \\
\hline $1973-74 \ldots \ldots \ldots$ & 709 & 5,647 & 1 & 6,357 & 438 & 4,193 & 1,243 & 5,874 \\
\hline $1974-75 \ldots \ldots \ldots \ldots$ & 483 & 4,651 & 2 & 5,136 & 450 & 3,178 & 1,149 & 4,777 \\
\hline $1975-76 \ldots \ldots \ldots$. & 361 & 5,829 & 2 & 6,192 & 490 & 3,592 & 1,711 & 5,793 \\
\hline $1976-77 \ldots \ldots \ldots$ & 399 & 6,266 & 3 & 6,668 & 513 & 3,587 & 1,684 & 5,784 \\
\hline $1977-78 \ldots \ldots \ldots \ldots$ & 884 & 6,426 & 3 & 7,312 & 551 & 3,710 & 1,948 & 6,208 \\
\hline $1978-79 \ldots \ldots \ldots$ & 1,104 & 7,087 & 1 & 8,191 & 575 & 4,198 & 2,133 & 6,906 \\
\hline $1979-80^{b} \ldots \ldots \ldots$ & 1,286 & 7,764 & 1 & 9,051 & 614 & 4,350 & 2,400 & 7,364 \\
\hline
\end{tabular}

Beginning October 1.

- Preliminary data.

Source: Feed Situation, Economics and Statistics Service, U.S. Department of Agriculture (various issues).

elevators, feed manufacturers, export elevators, commercial feedlots, and processors. A representative from each state's Agricultural Experiment Station was responsible for drawing the sample and conducting the interviews.

The sampling of inland grain elevators in each state was carried out by listing the elevators in descending order of storage capacity. Starting with the largest, elevators were added to the sample until the total of their storage capacities was equal to at least 25 percent of the inland elevator storage capacity in that state. Not less than 10 percent of the remaining elevators were then selected at random. For river elevators the procedure was simpler: a minimum of 50 percent of the elevators were selected by random sampling.

Feed manufacturing firms in each state were arrayed on the basis of their production capacity. Starting with the largest, feed firms on the list were added to the sample until the total of their production capacities equalled or exceeded 10 percent of the total feed manufacturing capacity in the state. Ten percent or more of the remaining firms were then selected at random and included in the sample. All exporters and processors were included in the interviews.* Data based on random samples were expanded in proportion to the sampling rate to convert the data into estimates for the entire region or state.

The same types of information were gathered from all of the grain handlers and processors interviewed. Each firm was asked to identify the volume of grain that it received from each region and the volume that moved by each mode of transportation.
The firms were also asked to identify each region or port area for which their shipments were destined and the quantity shipped by each mode.

Experiment Station representatives verified the accuracy of the data collected, expanded the sample data to state totals, and delivered the summary data for each grain and for every substate region to the U.S. Department of Agriculture for processing. As receivers' and shippers' data were tabulated, the Experiment Station representative in each state checked any discrepancies to identify potential data errors and to arrive at a single number for each origin-destination pair. Insofar as possible, the state representative checked data to ascertain that they were consistent and logical.

\section{VERIFICATION OF DATA}

The accuracy of the data on the volume of corn shipped between the various origins and destinations by each mode of transportation was verified by several direct and indirect comparisons with data from other sources. One indirect check was made by adding receipts to the surplus or deficit ${ }^{+}$ to obtain the supply available for shipment from each state. Exact correspondence between the supply and reported shipments was not expected since

\footnotetext{
* Only one major processor did not provide data for the study. Data on receipts by that firm were estimated from information furnished by shippers.

t The surplus or deficit for each state was calculated by adding the 1977 production to the stocks in all positions as of January 1, 1977, then subtracting the amount used for livestock, processors, and seed and deducting the stocks in all positions as of January 1, 1978.
} 


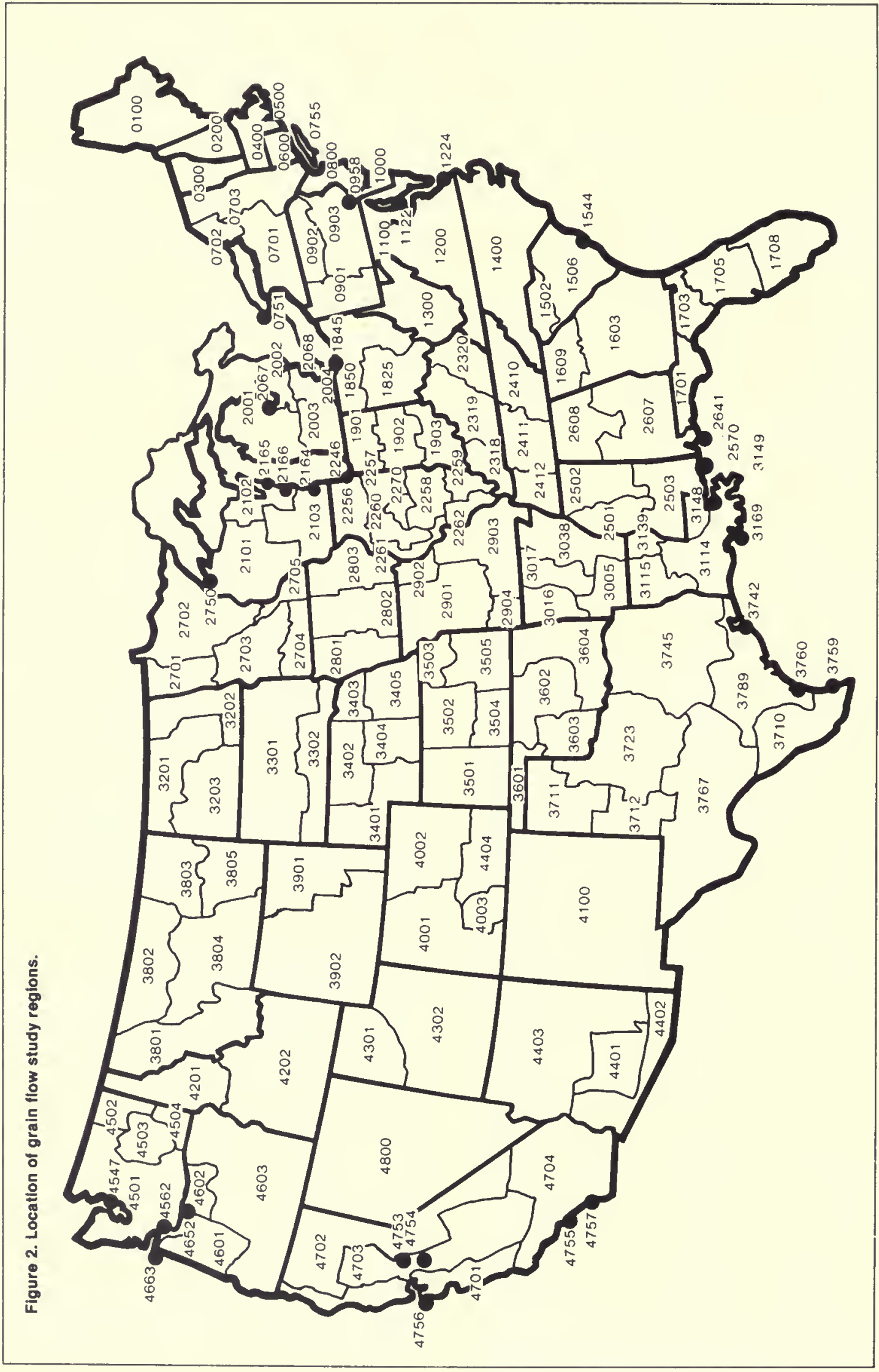


Table 3. Export Reglons, Port Areas, and the Ports Included in Each Area

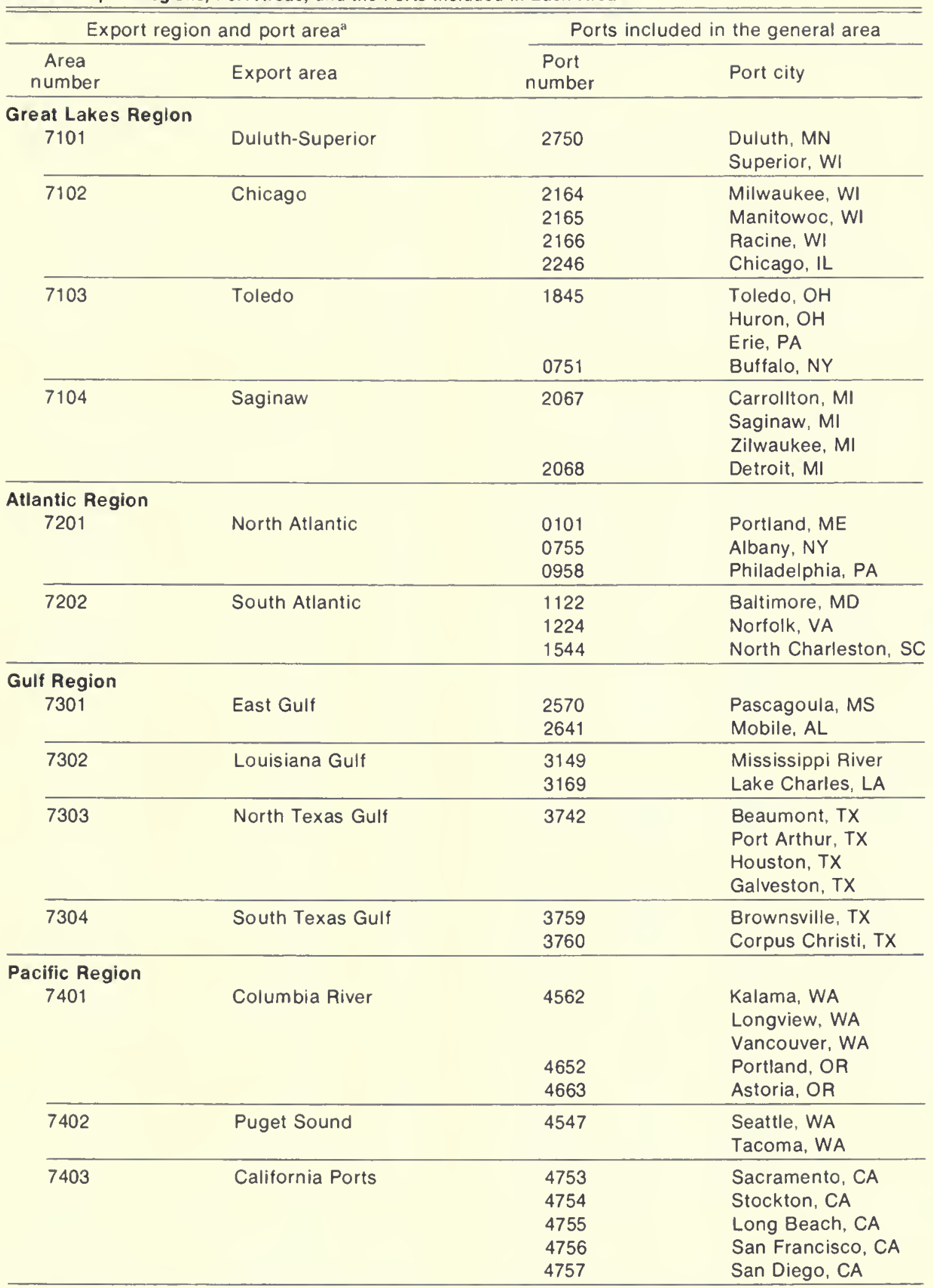

a These port areas will be used in this report to avoid disclosure of data from individual firms. 
the data on corn consumption by livestock and processors were based on estimates. Any major discrepancies, however, were investigated to verify that they did not indicate significant errors in the survey data.

A second check on total volume was made by comparing total receipts at each port with official data on inspections for export as published by the Market News Service of the U.S. Department of Agriculture (Table 4). Because there were few opportunities for either set of data to miss significant volumes, these numbers compared very closely. Discrepancies between receipts and exports at some of the port areas were explained by shipments to domestic destinations from export elevators, ship-

Table 4. Comparison of 1977 Corn Recelpts, Shipments, and Inspections for Export at Varlous Port Areas

\begin{tabular}{|c|c|c|c|}
\hline \multirow[t]{2}{*}{ Port area ${ }^{a}$} & \multicolumn{2}{|c|}{$\begin{array}{c}\text { Quantities determined } \\
\text { by survey }\end{array}$} & \multirow{2}{*}{$\begin{array}{l}\text { Quantities } \\
\text { based on } \\
\text { inspections } \\
\text { for export }\end{array}$} \\
\hline & Receipts $^{b}$ & Exports & \\
\hline
\end{tabular}
thousands of bushe/s

\section{Great Lakes Reglon}

\begin{tabular}{|c|c|c|c|}
\hline Duluth-Superior . . & 6,186 & 5,599 & 5,526 \\
\hline Chicago ....... & 118,851 & 52,083 & 48,403 \\
\hline Toledo.. & 84,793 & 84,933 & 84,933 \\
\hline Saginaw. & 3,595 & 3,576 & 3,576 \\
\hline Subtotal & 213,425 & 146,191 & 142,438 \\
\hline
\end{tabular}

\section{Atlantic Region}

\begin{tabular}{|c|c|c|c|}
\hline North Atlantic .... & 53,450 & 56,935 & 58,836 \\
\hline South Atlantic. & 329,350 & 273,802 & 299,087 \\
\hline ubtotal & 382,800 & 330.737 & 357.923 \\
\hline
\end{tabular}

Gulf Reglon

\begin{tabular}{|c|c|c|c|}
\hline East Gulf .... & 20,984 & 22,320 & 19,035 \\
\hline Louisiana Gulf & $1,004,562$ & 953,982 & 950,527 \\
\hline North Texas Gulf & 89,595 & 91,908 & 91,766 \\
\hline South Texas Gulf & 655 & 0 & 380 \\
\hline Subtotal ...... & $1,115,796$ & $1,068,210$ & $\overline{1,061,708}$ \\
\hline
\end{tabular}

Paclflc Region

\begin{tabular}{|c|c|c|c|}
\hline Columbia River... & 2,883 & 69 & 0 \\
\hline Puget Sound ..... & 8,477 & 18 & \\
\hline California ... & 16,055 & 13,947 & 14,755 \\
\hline Subtotal & 27,415 & 14,034 & 14,755 \\
\hline
\end{tabular}

Total ............ 1,739,436 1,559,172 $1,576,824$

- See Table 3 for identification of the port cities included in each port area.

beceipts exceeded exports in many ports because of domestic shipments, processing within the port area, and changes in inventory.

"Inspections for export conducted under the United States Grain Standards Act and reported in Grain Market News, Agricultural Marketing Service, U.S. Department of Agriculture, Vol. 26, No. 2 (January 13, 1978), p. 18. ments to processing plants located in the port area, and changes in inventory.

Supplemental information about grain shipments on inland waterways was provided by the U.S. Army Corps of Engineers. Since these data were based on the actual bill of lading for each shipment, they were, in principle, a complete census of all barge shipments. As Table 5 shows, the survey data and the Corps data on state-to-state shipments on inland waterways correspond closely. Differences between the two sets of data can be explained by (1) a significant number of shipments for which the origins and destinations are noted as "unknown" in the Corps data, (2) changes in the destination of a barge after it left the loading dock, (3) incomplete

Table 5. Comparison of 1977 Waterway Movements of Corn In the U.S. as Reported by Survey Respondents and the U.S. Army Corps of Englneers

\begin{tabular}{cccc}
\hline \hline $\begin{array}{c}\text { Originating } \\
\text { state }\end{array}$ & $\begin{array}{c}\text { Destination } \\
\text { state }^{\text {a }}\end{array}$ & $\begin{array}{c}\text { Survey } \\
\text { results }\end{array}$ & $\begin{array}{c}\text { Corps of } \\
\text { Engineers } \\
\text { data }\end{array}$ \\
\hline
\end{tabular}

thousands of bushe/s

\begin{tabular}{|c|c|c|c|}
\hline Alabama & $\begin{array}{l}\text { Ala., Miss., \& Tenn. } \\
\text { Subtotal }\end{array}$ & $\begin{array}{l}3,058 \\
3,058\end{array}$ & $\frac{2,380}{2,380}$ \\
\hline Illinois & \begin{tabular}{l} 
Ala., Miss., \& Tenn. \\
Arkansas \\
Florida \\
Illinois \\
lowa \\
Louisiana \\
Missouri \\
West Virginia \\
Unknown \\
\multicolumn{1}{c}{ Subtotal }
\end{tabular} & $\begin{array}{r}19,772 \\
0 \\
1,700 \\
4,196 \\
0 \\
504,766 \\
0 \\
0 \\
0 \\
530,434 \\
\end{array}$ & $\begin{array}{r}19,395 \\
45 \\
1,812 \\
2,324 \\
56 \\
477,484 \\
166 \\
46 \\
7,120 \\
508,484 \\
\end{array}$ \\
\hline Indiana & $\begin{array}{l}\text { Ala., Miss., \& Tenn. } \\
\text { Indiana } \\
\text { Louisiana } \\
\text { Unknown }\end{array}$ & $\begin{array}{r}9,424 \\
0 \\
15,790 \\
0 \\
\end{array}$ & $\begin{array}{r}558 \\
52 \\
28,004 \\
101 \\
\end{array}$ \\
\hline & Subtotal & 25,214 & 28,715 \\
\hline lowa & $\begin{array}{l}\text { Ala., Miss., \& Tenn. } \\
\text { Illinois } \\
\text { lowa } \\
\text { Louisiana } \\
\text { Unknown } \\
\quad \text { Subtotal } \\
\end{array}$ & $\begin{array}{r}442 \\
0 \\
0 \\
156,449 \\
0 \\
156,891 \\
\end{array}$ & $\begin{array}{r}2,607 \\
106 \\
53 \\
98,051 \\
1,827 \\
102,644 \\
\end{array}$ \\
\hline Kentucky & $\begin{array}{l}\text { Ala., Miss., \& Tenn. } \\
\text { Illinois } \\
\text { Louisiana } \\
\text { Unknown } \\
\quad \text { Subtotal }\end{array}$ & $\begin{array}{r}2,690 \\
0 \\
43,640 \\
0 \\
46,330\end{array}$ & $\begin{array}{r}1,263 \\
287 \\
32,624 \\
755 \\
34,929\end{array}$ \\
\hline Louisiana & $\begin{array}{l}\text { Ala., Miss., \& Tenn. } \\
\text { Florida }\end{array}$ & $\begin{array}{r}0 \\
50\end{array}$ & $\begin{array}{r}1,230 \\
0\end{array}$ \\
\hline
\end{tabular}


Teble 5-Continued

\begin{tabular}{cccc}
\hline $\begin{array}{c}\text { Originating } \\
\text { state }\end{array}$ & $\begin{array}{c}\text { Destination } \\
\text { state }^{\mathrm{a}}\end{array}$ & $\begin{array}{c}\text { Survey } \\
\text { results }\end{array}$ & $\begin{array}{c}\text { Corps of } \\
\text { Engineers } \\
\text { data }\end{array}$ \\
\hline
\end{tabular}

thousands of bushels

\begin{tabular}{|c|c|c|c|}
\hline Louisiana, & Illinois & 0 & 269 \\
\hline cont. & lowa & 0 & 160 \\
\hline & Louisiana & 0 & 1,239 \\
\hline & Missouri & 0 & 21 \\
\hline & N.J., N.Y., \& Penn. & 0 & 1 \\
\hline & Subtotal & 50 & 2,920 \\
\hline Minnesota & Ala., Miss., \& Tenn. & 1,175 & 1,073 \\
\hline & Arkansas & 0 & 46 \\
\hline & lowa & 0 & 95 \\
\hline & Louisiana & 75,398 & 69,069 \\
\hline & Unknown & 0 & 3,160 \\
\hline & Subtotal & 76,573 & 73,443 \\
\hline Missouri & Ala., Miss., \& Tenn. & 2,350 & 625 \\
\hline & Louisiana & 28,806 & 29,464 \\
\hline & Unknown & 0 & 841 \\
\hline & Subtotal & 31,156 & 30,930 \\
\hline
\end{tabular}

\begin{tabular}{|c|c|c|c|}
\hline $\begin{array}{l}\text { North } \\
\text { Carolina }\end{array}$ & $\begin{array}{l}\text { Delaware } \\
\text { Virginia } \\
\text { Subtotal }\end{array}$ & $\begin{array}{r}0 \\
2,348 \\
2,348\end{array}$ & $\begin{array}{r}43 \\
1,935 \\
1,978 \\
\end{array}$ \\
\hline Ohio & $\begin{array}{l}\text { Ala., Miss., \& Tenn. } \\
\text { Kentucky } \\
\text { Louisiana } \\
\text { Ohio } \\
\quad \text { Subtotal }\end{array}$ & $\begin{array}{r}2,574 \\
0 \\
28,230 \\
0 \\
30,804\end{array}$ & $\begin{array}{r}2,426 \\
45 \\
30,836 \\
58 \\
33,365\end{array}$ \\
\hline Tennessee & $\begin{array}{l}\text { Kentucky } \\
\text { Louisiana } \\
\text { Unknown } \\
\text { Subtotal }\end{array}$ & $\begin{array}{r}0 \\
2,231 \\
0 \\
2,231 \\
\end{array}$ & $\begin{array}{r}34 \\
2,353 \\
260 \\
2,647\end{array}$ \\
\hline Virginia & $\begin{array}{l}\text { Maryland \& Virginia } \\
\text { Unknown } \\
\text { Subtotal }\end{array}$ & $\begin{array}{r}2,088 \\
0 \\
2,088 \\
\end{array}$ & $\begin{array}{r}2,543 \\
24,297 \\
26,840 \\
\end{array}$ \\
\hline Wisconsin & $\begin{array}{l}\text { Ala., Miss., \& Tenn. } \\
\text { Louisiana } \\
\text { Subtotal }\end{array}$ & $\begin{array}{r}0 \\
3,350 \\
3,350\end{array}$ & $\begin{array}{r}265 \\
2,649 \\
2,914\end{array}$ \\
\hline
\end{tabular}

Other

\begin{tabular}{|c|c|c|c|}
\hline States $^{c}$ & All States & 3,320 & 3,658 \\
\hline \multicolumn{4}{|l|}{ Jther } \\
\hline States & Unknown & 0 & 5,322 \\
\hline Jnknown & Unknown & 0 & 904 \\
\hline & Subtotal & 3,320 & 9,884 \\
\hline & & 913,847 & 862,073 \\
\hline
\end{tabular}

- Data for some states were combined to avoid disclosure of volumes handled by individual firms.

"Corps of Engineers data tapes listed some origins and destinations as unknown. Much of the unknown data represented vessel loadings for export and insofar as possible were deleted from the "unknown" rows shown in this table.

"Data for all originating states with total barge shipments of less than 2 million bushels have been combined into the "other states" category. reporting of loadings to the Corps of Engineers, and (4) reporting errors by survey respondents. The Corps data underreport the survey results by 5.7 percent for the entire U.S. The greatest discrepancies are in the data for Iowa and Illinois, where all river elevators were included in the survey. Allocation of the "unknown" destinations and origins reduces this discrepancy.

The last method of validation provides important insight into data available from the U.S. Department of Transportation that are based on a 1 percent sample of all rail bills of lading. Shipment and receipt data were summarized into state totals and then compared with the rail shipments reported by survey respondents (Table 6). There are some similarities, but there are also many major differences. These discrepancies appear to be greatest for cases where unit trains account for a large share of the shipments between states, and they appear to be smallest where single-car shipments predominate. For example, the survey data on Illinois shipments to Louisiana exceeded the quantities determined from waybill statistics by a factor of 10, whereas the two sources of data on shipments to Pennsylvania, Wisconsin, and Arkansas corresponded quite closely. Additional analysis of both data sets led to the conclusion that there are serious sampling errors in the 1 percent waybill statistics and that those data should therefore be used with caution, especially where grain is known to move under unit train rates.

The comparisons between various data sources increase the confidence in the accuracy of estimates derived from sampling a less than perfectly identified population. The logic of each flow reported in these tables has been checked by the university person that organized the survey in each state. Where internal inconsistencies were found, the data and the sampling rates were adjusted with assistance from grain specialists and industry personnel in the state. The flow estimates presented in the following sections represent the best information available on the actual volume of corn transported between the regions of the United States.

\section{OVERVIEW OF MOVEMENTS}

This section summarizes selected data and presents an overview of com movement patterns. Detailed data on receipts and shipments for each area are presented in the last section of this bulletin.

\section{Shipments and Receipts by State}

In 1977, grain marketing firms in the United States reported shipping approximately 6.7 billion bushels 
Table 6. Comparison of 1977 Rall Movements of Corn as Reported by Survey Respondents and as Estimated from the 1 Percent Waybill Sample

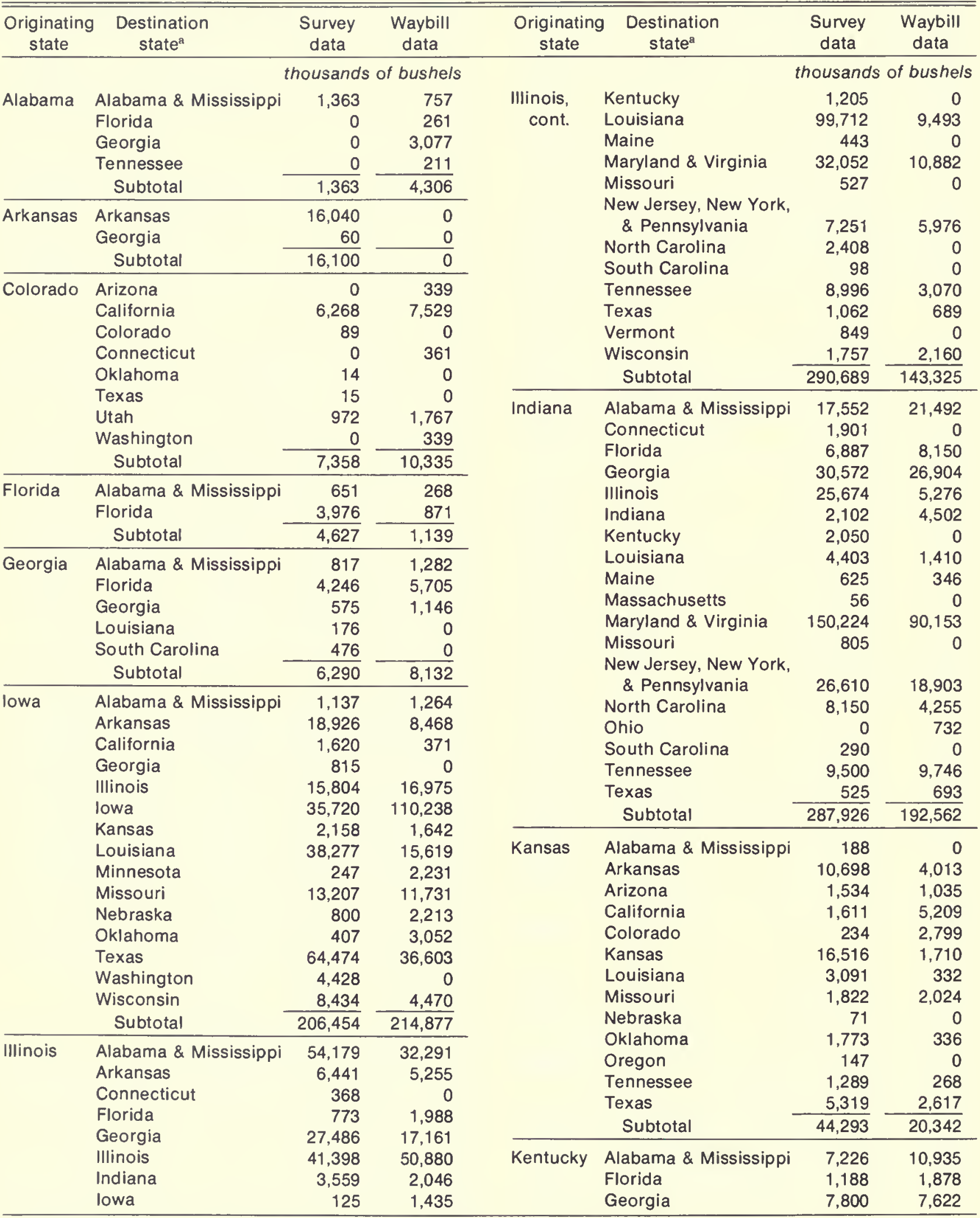

\footnotetext{
"Data for some states were combined to avoid possible disclosure of individual firms' data.
} 
Table 6 - Continued

\begin{tabular}{|c|c|c|c|c|c|c|c|}
\hline $\begin{array}{c}\text { Originating } \\
\text { state }\end{array}$ & $\begin{array}{c}\text { Destination } \\
\text { state }^{\mathrm{a}}\end{array}$ & $\begin{array}{c}\text { Survey } \\
\text { data }\end{array}$ & $\begin{array}{l}\text { Waybill } \\
\text { data }\end{array}$ & $\begin{array}{c}\text { Originating } \\
\text { state }\end{array}$ & $\begin{array}{c}\text { Destination } \\
\text { state }^{\mathrm{a}}\end{array}$ & $\begin{array}{c}\text { Survey } \\
\text { data }\end{array}$ & $\begin{array}{c}\text { Waybill } \\
\text { data }\end{array}$ \\
\hline \multicolumn{6}{|c|}{ thousands of bushels } & \multicolumn{2}{|c|}{ thousands of bushels } \\
\hline \multirow{8}{*}{$\begin{array}{l}\text { Kentucky, } \\
\text { cont. }\end{array}$} & Kentucky & 6,176 & 0 & North & Minnesota & 383 & 0 \\
\hline & Maryland \& Virginia & 45 & 1,599 & Dakota & Missouri & 527 & 0 \\
\hline & Missouri & 102 & 0 & & Oregon & 0 & 1,778 \\
\hline & North Carolina & 3,701 & 1,803 & & Utah & 500 & 0 \\
\hline & South Carolina & 140 & 1,014 & & Wisconsin & 4,867 & 211 \\
\hline & Tennessee & 7,098 & 3,731 & & Wyoming & 500 & 0 \\
\hline & West Virginia & 302 & 0 & & Subtotal & 6,777 & 1,989 \\
\hline & Subtotal & 33,778 & 28,581 & Nebraska & Alabama \& Mississippi & 3,638 & 0 \\
\hline \multirow[t]{8}{*}{ Michigan } & Connecticut & 4,003 & 1,057 & & Arkansas & 26,533 & 13,880 \\
\hline & Maine & 8,658 & 4,188 & & Arizona & 1,543 & 3,156 \\
\hline & Maryland \& Virginia & 14,122 & 9,882 & & California & 74,949 & 24,055 \\
\hline & Massachusetts & 302 & 4,088 & & Colorado & 35,619 & 29,645 \\
\hline & New Jersey, New York, & & & & lowa & 2,848 & 7,579 \\
\hline & \& Pennsylvania & 6,090 & 1,303 & & Kansas & 17,596 & 9,289 \\
\hline & Vermont & 1,920 & 2,028 & & Louisiana & 935 & 7,658 \\
\hline & Subtotal & 35,095 & 22,545 & & Minnesota & 206 & 0 \\
\hline \multirow{13}{*}{ Minnesota } & Alabama \& Mississippi & 25 & 0 & & Missouri & 9,142 & 23,937 \\
\hline & Illinois & 0 & 339 & & Nebraska & 55,647 & 18,361 \\
\hline & lowa & 231 & 671 & & Nevada & 162 & 357 \\
\hline & Louisiana & 23,484 & 1,135 & & Oklahoma & 725 & 3,124 \\
\hline & Michigan & 19 & 0 & & Oregon & 2,647 & 3,095 \\
\hline & Minnesota & 37,709 & 20,328 & & Tennessee & 3 & 0 \\
\hline & North Dakota & 1,496 & 0 & & Texas & 22,357 & 32,937 \\
\hline & Oregon & 3,971 & 343 & & Utah & 2,351 & 0 \\
\hline & South Dakota & 208 & 0 & & Washington & 9,235 & 6,276 \\
\hline & Texas & 3,256 & 1,235 & & Subtotal & 266,136 & 183,349 \\
\hline & Washington & 0 & 643 & New York & Connecticut & 0 & 211 \\
\hline & Wisconsin & 372 & 4,734 & & Maine & 1,666 & 339 \\
\hline & Subtotal & 70,771 & 29,428 & & Massachusetts & 82 & 0 \\
\hline \multirow[t]{14}{*}{ Missouri } & Alabama \& Mississippi & 2,621 & 0 & & $\begin{array}{l}\text { New Hampshire } \\
\text { New Jersey, New York }\end{array}$ & 86 & 361 \\
\hline & Arkansas & 16,713 & 11,206 & & \& Pennsylvania & 385 & 436 \\
\hline & California & 245 & 353 & & Vermont & 297 & 0 \\
\hline & Illinois & 43 & 0 & & Subtotal & 2,516 & 1,346 \\
\hline & $\begin{array}{l}\text { lowa } \\
\text { Kansas }\end{array}$ & $\begin{array}{r}98 \\
3,171\end{array}$ & $\begin{array}{r}0 \\
2,260\end{array}$ & Ohio & Alabama \& Mississippi & 11 & 0 \\
\hline & Kentucky & 438 & $\begin{array}{r}2, \angle 00 \\
0\end{array}$ & & Connecticut & 2,962 & 2,096 \\
\hline & Louisiana & 173 & 1,121 & & Georgia & 5,000 & 2,345 \\
\hline & Missouri & 12,767 & 6,937 & & Maine & 1,934 & 2,395 \\
\hline & Nebraska & 0 & 200 & & Maryland \& Virginia & 91,443 & 64,285 \\
\hline & New Mexico & 636 & 0 & & North Carolina & 12,147 & 11,292 \\
\hline & Oklahoma & 524 & 1,017 & & New Jersey, New York, & & \\
\hline & Tennessee & 372 & 0 & & \& Pennsylvania & 32,940 & 39,944 \\
\hline & Texas & 4,936 & 6,862 & & Ohio & 6,335 & 2,445 \\
\hline & Subtotal & 42,737 & 29,956 & & South Carolina & 14,828 & 5,551 \\
\hline \multirow{2}{*}{$\begin{array}{l}\text { Missis- } \\
\text { sippi }\end{array}$} & Mississippi & 1,775 & 1,085 & & Vermont & 1.022 & 1,353 \\
\hline & Subtotal & 1,775 & 1,085 & & West Virginia & 1,899 & 0 \\
\hline \multirow{6}{*}{$\begin{array}{l}\text { North } \\
\text { Caro- } \\
\text { lina }\end{array}$} & Florida & 709 & 2,078 & & Subtotal & 171,440 & 131,708 \\
\hline & Georgia & 0 & 182 & Pennsyl- & Connecticut & 0 & 618 \\
\hline & Maryland \& Virginia & 1,904 & 3,420 & vania & Maine & 28 & 0 \\
\hline & North Carolina & 4,067 & 7,697 & & New Hampshire & 78 & 0 \\
\hline & South Carolina & 4 & 0 & & New Jersey, New York, & & \\
\hline & Subtotal & 6,684 & 13,377 & & \& Pennsylvania & 97 & 1,971 \\
\hline
\end{tabular}


Table 6 - Continued

\begin{tabular}{|c|c|c|c|c|c|c|c|}
\hline $\begin{array}{c}\text { Originating } \\
\text { state }\end{array}$ & $\begin{array}{c}\text { Destination } \\
\text { state }^{\mathrm{a}}\end{array}$ & $\begin{array}{c}\text { Survey } \\
\text { data }\end{array}$ & $\begin{array}{c}\text { Waybill } \\
\text { data }\end{array}$ & $\begin{array}{c}\text { Originating } \\
\text { state }\end{array}$ & $\begin{array}{c}\text { Destination } \\
\text { state }^{\mathbf{a}}\end{array}$ & $\begin{array}{c}\text { Survey } \\
\text { data }\end{array}$ & $\begin{array}{c}\text { Waybill } \\
\text { data }\end{array}$ \\
\hline \multicolumn{6}{|c|}{ thousands of bushels } & \multicolumn{2}{|c|}{ thousands of bushels } \\
\hline \multirow{2}{*}{$\begin{array}{l}\text { Penn., } \\
\text { cont. }\end{array}$} & \multirow{2}{*}{$\begin{array}{l}\text { Vermont } \\
\text { Subtotal }\end{array}$} & 88 & 0 & \multirow{2}{*}{\multicolumn{2}{|c|}{$\begin{array}{r}\text { Tennessee } \\
\text { Subtotal }\end{array}$}} & 763 & 1,396 \\
\hline & & 291 & 2,588 & & & 3,747 & 10,257 \\
\hline \multirow{7}{*}{$\begin{array}{l}\text { South } \\
\text { Carolina }\end{array}$} & Florida & 540 & 3,659 & \multirow[t]{9}{*}{ Texas } & California & 10,656 & 3,848 \\
\hline & Georgia & 111 & 0 & & Kansas & 101 & 0 \\
\hline & Maryland \& Virginia & 805 & 1,521 & & Kentucky & 0 & 357 \\
\hline & North Carolina & 36 & 0 & & Mississippi & 68 & 0 \\
\hline & South Carolina & 1,230 & 0 & & Ohio & 0 & 353 \\
\hline & West Virginia & 80 & 0 & & Pennsylvania & 0 & 707 \\
\hline & Subtotal & 2,802 & 5,180 & & Texas & 28,599 & 27,068 \\
\hline South & lowa & 107 & 339 & & Washington & 0 & 625 \\
\hline \multirow{8}{*}{ Dakota } & Kansas & 40 & 221 & & Subtotal & 39,424 & 32,958 \\
\hline & Minnesota & 1,141 & 0 & \multirow{8}{*}{ Wisconsin } & Illinois & 2,081 & 1,428 \\
\hline & Nebraska & 92 & 571 & & Indiana & 500 & 0 \\
\hline & Oregon & 386 & 0 & & lowa & 17 & 0 \\
\hline & Texas & 383 & 557 & & Minnesota & 271 & 0 \\
\hline & Washington & 136 & 343 & & New York & 0 & 132 \\
\hline & Wisconsin & 0 & 350 & & Pennsylvania & 48 & 0 \\
\hline & Subtotal & 2,285 & 2,381 & & Wisconsin & 5,288 & 3,027 \\
\hline \multicolumn{2}{|c|}{ Tennessee Alabama } & 0 & 2,171 & & Subtotal & 8,205 & 4,587 \\
\hline & $\begin{array}{l}\text { Florida } \\
\text { Georaia }\end{array}$ & $\begin{array}{r}51 \\
1.200\end{array}$ & $\begin{array}{l}546 \\
557\end{array}$ & \multicolumn{2}{|l|}{ Other ${ }^{b}$} & 2,095 & 6,494 \\
\hline & Mississippi & 1,733 & 5,587 & \multicolumn{2}{|l|}{ U.S. total } & $1,545,558$ & $1,102,827$ \\
\hline
\end{tabular}

'States originating less than 1 million bushels by rail were combined into the "other" category.

of corn including exports. Much of this total amount is accounted for by the same grain being shipped in sequence by several firms. About 37 percent of the amount shipped moved to destinations within the state in which it originated. These intrastate shipments for each state and mode of transportation are summarized in Table 7 . Trucks were the predominant mode of transportation, accounting for 75 percent of the total intrastate shipment volume. Rail shipments accounted for 11.2 percent of the total, and 13.4 percent moved to local farmers. Less than 1 percent of the corn shipped within state boundaries was conveyed by barge. If only commercial shipments are considered (eliminating farm truck) the modal splits are: rail, $\mathbf{1 2 . 9}$ percent; truck, 66.4 percent; and barge, 4.3 percent. A sizeable portion of the intrastate movements consisted of shipments from country elevators to terminal elevators for storage and reshipment. Movements within the state of Illinois accounted for more than one-fourth of the total volume of intrastate shipments in the U.S. Sizeable movements also occurred in Iowa and Minnesota.

In contrast to intrastate movements, the predominant mode of transportation used for interstate shipments was the railroad, which carried 1.3 billion bushels or 49.0 percent of the total volume (Table 8). Over half of the rail shipments in the United States originated in Illinois, Indiana, and Nebraska. A large portion of the Indiana rail shipments moved to ports on the East Coast. The southeastern feed markets were a secondary destination. For Illinois, the Gulf ports were the principal destinations, but significant quantities went to the East Coast and to the southeastern feed markets. California was a principal recipient of Nebraska's rail shipments, although the Arkansas feed market and the Texas ports were also important destinations for those shipments.

Interstate truck shipments originating in Indiana and Iowa accounted for more than one-third of the total volume shipped across state lines by truck. Most of these shipments moved short distances to the neighboring states of Illinois, Minnesota, and Missouri, where some were delivered to feed processors and others were reshipped to export points. Truck shipments from Illinois to out-of-state destinations totalled only 41 million bushels. Rates for moving grain over long distances by truck are higher than those for shipping it by rail or barge.

Barges carried 34.7 percent of the com shipped across state lines; Illinois originated 58 percent of 
the total volume shipped in the U.S. by barge. Nearly all com shipped by water, regardless of the state in which it originated, was destined for export.

The volume of corn received in each state from other states is shown in Table 9. Port areas were the predominant destinations. About half of the corn received in those areas arrived by rail and half by barge. The large volume of rail and truck shipments received by Illinois firms indicates the state's importance as an assembly and reshipment point.

\section{Movements to Ports}

Table 10 shows the amount of corn that moved to port locations from each of the originating states by the various modes of transportation. The Gulf region received the largest volume of corn, accounting for over one-half of the total received by all ports. Most of this volume ( 77.6 percent) moved by water from midwestern origins. Twenty-two percent of the corn shipped to the Gulf ports went by rail. Illinois and Iowa were the states that shipped the greatest amount of grain for export, although

Table 7. 1977 Intrastate Shlpments of Corn for Each State and Mode of Transportation

\begin{tabular}{|c|c|c|c|c|c|}
\hline \multirow{2}{*}{$\begin{array}{c}\text { Originating } \\
\text { state }\end{array}$} & \multicolumn{4}{|c|}{ Mode of transportation } & \multirow{2}{*}{ Total } \\
\hline & Rail & Truck & Barge & Farm truck & \\
\hline & \multicolumn{5}{|c|}{ thousands of bushels } \\
\hline Alabama $\ldots \ldots \ldots \ldots \ldots \ldots$ & 1,318 & 12,946 & 3,008 & 3,595 & 20,867 \\
\hline Arizona $\ldots \ldots \ldots \ldots \ldots \ldots \ldots$ & 151 & 2,505 & 0 & 0 & 2,656 \\
\hline Arkansas $\ldots \ldots \ldots \ldots \ldots \ldots \ldots$ & . 16,040 & 5,083 & 0 & 86 & 21,209 \\
\hline California $\ldots \ldots \ldots \ldots \ldots \ldots \ldots$ & . 173 & 21,117 & 0 & 0 & 21,290 \\
\hline Colorado....................... & 89 & 7,532 & 0 & 0 & 7,621 \\
\hline 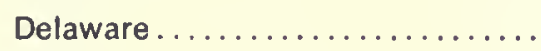 & 0 & 7,448 & 0 & 0 & 7,448 \\
\hline Florida...$\ldots \ldots \ldots \ldots \ldots \ldots \ldots$ & 3,976 & 2,204 & 0 & 120 & 6,300 \\
\hline Georgia...$\ldots \ldots \ldots \ldots \ldots \ldots$ & . $\quad 575$ & 25,569 & 0 & 11,210 & 37,354 \\
\hline Illinois ......... & . 41,398 & 573,365 & 4,196 & 20,730 & 639,689 \\
\hline Indiana ... & - 2,102 & 174,806 & 0 & 1,860 & 178,768 \\
\hline lowa ............ & . 35,720 & 258,777 & 0 & 205,135 & 499,632 \\
\hline Kansas......... & . 16,516 & 34,951 & 0 & 0 & 51,467 \\
\hline Kentucky.................. & . $\quad 6,176$ & 5,637 & 0 & 0 & 11,813 \\
\hline Louisiana ....... & 0 & 4,790 & 0 & 0 & 4,790 \\
\hline Maryland ........ & 0 & 14,568 & 71 & 0 & 14,639 \\
\hline Michigan $. . . \ldots \ldots \ldots \ldots \ldots . . .$. & . 0 & 17,445 & 0 & 0 & 17,445 \\
\hline Minnesota $\ldots \ldots \ldots \ldots \ldots \ldots \ldots$ & . 37,709 & 181,883 & 0 & 38,160 & 257,752 \\
\hline Mississippi $\ldots \ldots \ldots \ldots \ldots \ldots \ldots \ldots$ & . 1,775 & 2,003 & 0 & 497 & 4,275 \\
\hline Missouri $\ldots \ldots \ldots \ldots \ldots \ldots \ldots$ & . 12,767 & 36,431 & 0 & 0 & 49,198 \\
\hline Nebraska & . 55,647 & 141,071 & 0 & 41,579 & 238,297 \\
\hline New York ..... & 293 & 712 & 0 & 150 & 1,155 \\
\hline North Carolina $. . . \ldots \ldots \ldots \ldots . .$. & 4,067 & 48,841 & 0 & 0 & 52,908 \\
\hline Ohio $\ldots \ldots \ldots \ldots \ldots \ldots \ldots \ldots$ & 6,335 & 117,003 & 0 & 0 & 123,338 \\
\hline Pennsylvania $\ldots \ldots \ldots \ldots \ldots \ldots$ & 0 & 34,598 & 0 & 0 & 34,598 \\
\hline South Carolina ................ & 1,230 & 5,662 & 0 & 3,422 & 10,314 \\
\hline Tennessee $\ldots \ldots \ldots \ldots \ldots \ldots \ldots$ & . $\quad 763$ & 10,267 & 0 & 2,114 & 13,144 \\
\hline Texas $\ldots \ldots \ldots \ldots \ldots \ldots \ldots \ldots \ldots \ldots$ & . 28,599 & 104,514 & 0 & 0 & 133,113 \\
\hline Vermont $\ldots \ldots \ldots \ldots \ldots \ldots \ldots \ldots$ & . $\quad 0$ & 0 & 0 & 4 & 4 \\
\hline Virginia $\ldots \ldots \ldots \ldots \ldots \ldots \ldots \ldots$ & 95 & 283 & 1,970 & 2,268 & 4,616 \\
\hline Wisconsin ................ & 5,288 & 15,757 & 0 & 2,341 & 23,386 \\
\hline Wyoming $\ldots \ldots \ldots \ldots \ldots \ldots$ & 0 & 0 & 0 & 45 & 45 \\
\hline Total volume.............. & $.278,802$ & $1,867,768$ & 9,245 & 333,316 & $2,489,131$ \\
\hline Percentage of total volume........ & 11.2 & 75.0 & 0.4 & 13.4 & 100.0 \\
\hline
\end{tabular}

Note: These data include shipments to port cities within the state but not exports to destinations outside the United States.

" This column reports saies by elevators to farmers within the state. Not all states included farm sales in their survey responses, so these data are incomplete and underestimate total shipments to farmers. 
Minnesota and Nebraska also shipped significant amounts to the Gulf by rail. The amount of corn received by truck in the export regions is not a very significant factor in the total pattern, but truck transportation to ports is of importance for some local sources such as Alabama and Texas.

The Atlantic ports are supplied primarily by rail shipments from the eastern corn belt states of Indiana and Ohio. Over 88 percent of the corn received by Atlantic ports moved by rail; 82 percent of that amount originated in Indiana and Ohio. Trucks also play an important role in moving corn from states such as North and South Carolina to the Atlantic export region.

Ports along the Great Lakes are supplied primarily (75 percent) by truck shipments originating in states adjacent to the lakes. Receipts of rail shipments originating in Illinois are of equal importance with truck shipments; in Minnesota truck shipments predominate. The Pacific export region

Table 8. 1977 Interstate ShIpments of Corn for Each State and Mode of Transportation

\begin{tabular}{|c|c|c|c|c|c|}
\hline \multirow{2}{*}{$\begin{array}{c}\text { Originating } \\
\text { state }\end{array}$} & \multicolumn{4}{|c|}{ Mode of transportation } & \multirow{2}{*}{ Total } \\
\hline & Rail & Truck & Barge & Farm truck ${ }^{a}$ & \\
\hline & \multicolumn{5}{|c|}{ thousands of bushels } \\
\hline Alabama $. . . . . . . \ldots \ldots \ldots . . .$. & 45 & 1,186 & 50 & 0 & 1,281 \\
\hline Arkansas $\ldots \ldots \ldots \ldots \ldots \ldots$ & 60 & 0 & 0 & 0 & 60 \\
\hline Colorado.................. & 7,269 & 2,053 & 0 & 0 & 9,322 \\
\hline Delaware... & 0 & 4,885 & 1,307 & 0 & 6,192 \\
\hline Florida...$\ldots \ldots \ldots \ldots \ldots \ldots$ & 651 & 421 & 117 & 0 & 1,189 \\
\hline Georgia...$\ldots \ldots \ldots \ldots \ldots$ & 5,715 & 3,710 & 0 & 0 & 9,425 \\
\hline Illinois $\ldots \ldots \ldots \ldots \ldots \ldots \ldots$ & 249,291 & 41,095 & 526,238 & 0 & 816,624 \\
\hline Indiana .... & 285,824 & 76,648 & 25,214 & 217 & 387,903 \\
\hline 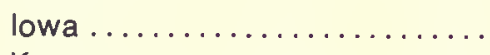 & 170,734 & 91,359 & 156,891 & 5,663 & 424,647 \\
\hline 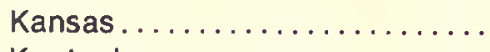 & 27,777 & 7,443 & 0 & 0 & 35,220 \\
\hline Kentucky.................. & 27,602 & 7,626 & 46,330 & 0 & 81,558 \\
\hline 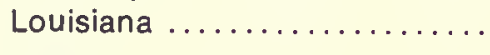 & 624 & 118 & 50 & 0 & 792 \\
\hline Maryland $\ldots \ldots \ldots \ldots \ldots \ldots \ldots$ & 161 & 7,173 & 0 & 0 & 7,334 \\
\hline Michigan ................. & 35,095 & 31,653 & 0 & 0 & 66,748 \\
\hline Minnesota . ................ & 33,062 & 16,514 & 76,573 & 380 & 126,529 \\
\hline Mississippi $\ldots \ldots \ldots \ldots \ldots \ldots$ & 0 & 1,788 & 0 & 0 & 1,788 \\
\hline Missouri $\ldots \ldots \ldots \ldots \ldots \ldots$ & 23,970 & 7,208 & 31,156 & 0 & 62,334 \\
\hline Nebraska $\ldots . . . . . \ldots \ldots \ldots . . .$. & 210,489 & 26,670 & 1,825 & 18,447 & 257,431 \\
\hline New Jersey ................. & 0 & 2,890 & 0 & 0 & 2,890 \\
\hline New Mexico ................ & 0 & 312 & 0 & 0 & 312 \\
\hline 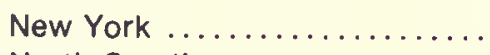 & 2,223 & 1,511 & 0 & 0 & 3,734 \\
\hline North Carolina.....$\ldots \ldots \ldots$ & 2,617 & 17,755 & 2,348 & 0 & 22,720 \\
\hline North Dakota ................ & 6,777 & 124 & 0 & 0 & 6,901 \\
\hline Ohio ........................ & 165,105 & 9,666 & 30,804 & 0 & 205,575 \\
\hline Oklahoma ................. & 92 & 785 & 0 & 0 & 877 \\
\hline Pennsylvania ................. & 291 & 3,810 & 0 & 0 & 4,101 \\
\hline South Carolina .............. & 1,572 & 1,011 & 0 & 44 & 2,627 \\
\hline South Dakota ............... & 2,285 & 4,337 & 0 & 0 & 6,622 \\
\hline Tennessee $\ldots \ldots \ldots \ldots \ldots \ldots$ & 2,984 & 1,903 & 2,231 & 0 & 7,118 \\
\hline Texas $\ldots \ldots \ldots \ldots \ldots \ldots \ldots \ldots$ & 10,825 & 776 & 0 & 0 & 11,601 \\
\hline Virginia $\ldots \ldots \ldots \ldots \ldots \ldots \ldots$ & 1,423 & 1,542 & 118 & 0 & 3,083 \\
\hline Wisconsin $\ldots \ldots \ldots \ldots \ldots \ldots$ & 2,917 & $\underline{24,738}$ & 3,350 & 51 & 31,056 \\
\hline Total volume $\ldots \ldots \ldots \ldots$ & $1,277,480$ & 398,710 & 904,602 & 24,802 & $2,605,591$ \\
\hline Percentage of total volume..... & 49.0 & 15.3 & 34.7 & 1.0 & 100.0 \\
\hline
\end{tabular}

Note: These data include shipments to port cities but not exports to destinations outside the United States. Exports by states are shown in Table 10.

a This column reports sales by elevators to farmers in other states. Not all states included farm sales in their survey responses, so these data are incomplete and underestimate total shipments to farmers. 
Table 9. 1977 Interstate Recelpta of Corn for Each State and Mode of Transportation

\begin{tabular}{|c|c|c|c|c|c|}
\hline \multirow{2}{*}{$\begin{array}{l}\text { Destination } \\
\text { state }\end{array}$} & \multicolumn{4}{|c|}{ Mode of transportation } & \multirow{2}{*}{ Total } \\
\hline & Rail & Truck & Barge & Farm truck ${ }^{a}$ & \\
\hline & \multicolumn{5}{|c|}{ thousands of bushels } \\
\hline Alabama $\ldots . . . \ldots \ldots \ldots \ldots$ & 52,692 & 8,112 & 32,210 & 0 & 93,014 \\
\hline Arizona $\ldots \ldots \ldots \ldots \ldots \ldots$ & 3,077 & 751 & 0 & 0 & 3,828 \\
\hline 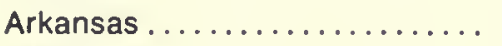 & 73,311 & 7,061 & 0 & 0 & 80,372 \\
\hline California $\ldots \ldots \ldots \ldots \ldots \ldots$ & 95,349 & 541 & 0 & 0 & 95,890 \\
\hline Colorado.................... & 35,853 & 2,851 & 0 & 0 & 38,704 \\
\hline Connecticut ............... & 9,395 & 0 & 0 & 0 & 9,395 \\
\hline Delaware.................. & 0 & 7,180 & 0 & 2,874 & 10,054 \\
\hline Florida...$\ldots \ldots \ldots \ldots \ldots$ & 14,394 & 2,245 & 1,750 & 0 & 18,389 \\
\hline Georgia ................. & 73,044 & 2,043 & 0 & 806 & 75,893 \\
\hline Illinois ..................... & 43,602 & 95,051 & 0 & 9,577 & 148,230 \\
\hline Indiana $\ldots \ldots \ldots \ldots \ldots \ldots \ldots$ & 4,059 & 14,614 & 0 & 22,183 & 40,856 \\
\hline lowa $\ldots \ldots \ldots \ldots \ldots \ldots \ldots \ldots$ & 3,426 & 14,105 & 0 & 69 & 17,600 \\
\hline Kansas $\ldots \ldots \ldots \ldots \ldots \ldots \ldots$ & 23,066 & 18,298 & 0 & 3,402 & 44,766 \\
\hline Kentucky ................. & 3,693 & 5,667 & 0 & 14,000 & 23,360 \\
\hline Louisiana .................... & 170,251 & 2,890 & 860,485 & 0 & $1,033,626$ \\
\hline Maine...$\ldots \ldots \ldots \ldots \ldots \ldots$ & 13,354 & 0 & 0 & 0 & 13,354 \\
\hline Maryland ......... & 132,487 & 8,231 & 212 & 2,307 & 143,237 \\
\hline Massachiusetts $\ldots \ldots \ldots \ldots \ldots$ & 440 & 0 & 0 & 0 & 440 \\
\hline Michigan $\ldots \ldots \ldots \ldots \ldots \ldots \ldots$ & 19 & 156 & 0 & 0 & 175 \\
\hline Minnesota $\ldots \ldots \ldots \ldots \ldots . . . .$. & 2,248 & 18,913 & 0 & 6,096 & 27,257 \\
\hline Mississippi .................. & 37,823 & 11,846 & 5,547 & 0 & 55,216 \\
\hline Missouri $\ldots \ldots \ldots \ldots \ldots \ldots$ & 26,132 & 18,858 & 0 & 0 & 44,990 \\
\hline Nebraska ................. & 963 & 7,601 & 0 & 3,081 & 11,645 \\
\hline Nevada $\ldots \ldots \ldots \ldots \ldots \ldots$ & 162 & 0 & 0 & 0 & 162 \\
\hline New Hampshire $\ldots \ldots \ldots \ldots$. & 164 & 30 & 0 & 0 & 194 \\
\hline New Jersey................. & 377 & 367 & 0 & 0 & 744 \\
\hline New Mexico ................ & 636 & 0 & 0 & 0 & 636 \\
\hline 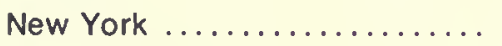 & 26,655 & 377 & 0 & 0 & 27,032 \\
\hline North Carolina $\ldots . . . \ldots \ldots \ldots$ & 27,865 & 2,198 & 0 & 0 & 30,063 \\
\hline North Dakota............... & 1,496 & 1,100 & 0 & 0 & 2,596 \\
\hline Ohio $\ldots \ldots \ldots \ldots \ldots \ldots \ldots$ & 0 & 47,282 & 0 & 22,110 & 69,392 \\
\hline Oklahoma ................... & 3,443 & 3,631 & 0 & 0 & 7,074 \\
\hline Oregon $\ldots \ldots \ldots \ldots \ldots \ldots$ & 7,151 & 77 & 0 & 0 & 7,228 \\
\hline Pennsylvania $\ldots \ldots \ldots \ldots \ldots \ldots$ & 46,096 & 10,599 & 0 & 2,862 & 59,557 \\
\hline South Carolina .............. & 15,836 & 1,604 & 0 & 91 & 17,531 \\
\hline South Dakota ............... & 208 & 4,702 & 0 & 0 & 4,910 \\
\hline Tennessee ................. & 28,177 & 13,666 & 837 & 639 & 43,319 \\
\hline Texas ..................... & 102,419 & 12,824 & 0 & 0 & 115,243 \\
\hline 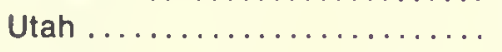 & 3,823 & 399 & 0 & 0 & 4,222 \\
\hline Vermont $\ldots \ldots \ldots \ldots \ldots \ldots . . . .$. & 4,176 & 236 & 0 & 166 & 4,578 \\
\hline Virginia $\ldots . . . \ldots \ldots \ldots \ldots \ldots$ & 158,108 & 16,878 & 3,561 & 3,476 & 182,023 \\
\hline Washington $\ldots \ldots \ldots \ldots \ldots$ & 13,799 & 0 & 0 & 0 & 13,799 \\
\hline West Virginia ................ & 2,281 & 20 & 0 & 0 & 2,301 \\
\hline 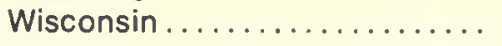 & 15,430 & 35,578 & 0 & 1,360 & 52,368 \\
\hline Wyoming $\ldots \ldots \ldots \ldots \ldots \ldots \ldots$. & 500 & 128 & $\underline{0}$ & 0 & 628 \\
\hline U.S. total ................. & $1,277,480$ & 398,710 & 904,602 & 95,099 & $2,675,891$ \\
\hline Percentage of total receipts .... & 47.7 & 14.9 & 33.8 & 3.6 & 100.0 \\
\hline
\end{tabular}

Note: Receipts at port cities are included in the data for the respective states.

- This column shows elevator receipts in each state from farmers located in all other states as reported by elevators in the receiving states. 
Table 10. 1977 Movements of Corn to Points of Export from Each Originating State by Three Modes of Traneportation.

\begin{tabular}{|c|c|c|c|c|c|c|}
\hline \multirow[b]{2}{*}{$\begin{array}{l}\text { Originating } \\
\text { state }\end{array}$} & \multirow[b]{2}{*}{$\begin{array}{l}\text { Export } \\
\text { region }\end{array}$} & \multicolumn{4}{|c|}{ Mode of transportation } & \multirow[b]{2}{*}{ Total } \\
\hline & & Rail & Truck & Barge & $\begin{array}{l}\text { Farm } \\
\text { truck }\end{array}$ & \\
\hline & & \multicolumn{5}{|c|}{ thousands of bushels } \\
\hline Alabama ......... & Gulf ............. & 0 & 1,061 & 2,381 & 100 & 3,542 \\
\hline California ......... & West Coast ........ & 0 & 429 & 0 & 5,275 & 5,704 \\
\hline Delaware ........ & Atlantic ........... & 0 & 90 & 1,307 & 0 & 1,397 \\
\hline Florida... & $\ldots \ldots \ldots \ldots$ & 651 & 421 & 117 & 0 & 1,189 \\
\hline Georgia . & $\ldots \ldots \ldots \ldots$ & 0 & 215 & 0 & 0 & 215 \\
\hline \multirow[t]{3}{*}{ Illinois... } & Atlantic & 35,805 & 15 & 0 & 0 & 35,820 \\
\hline & $\ldots \ldots \ldots \ldots$ & 2,645 & 23,668 & 3,665 & 95 & 30,073 \\
\hline & Gulf $\ldots \ldots \ldots \ldots \ldots$ & 85,113 & 403 & 500,711 & 0 & 586,227 \\
\hline \multirow[t]{3}{*}{ Indiana } & Atlantic $\ldots \ldots \ldots \ldots$ & 162,325 & 1,039 & 0 & 0 & 163,364 \\
\hline & Lake ............. & 0 & 28,335 & 0 & 628 & 28,963 \\
\hline & Gulf.............. & 4,658 & 0 & 15,790 & 0 & 20,448 \\
\hline \multirow[t]{3}{*}{ lowa } & Lake ............. & 19,074 & 13,754 & 0 & 0 & 32,828 \\
\hline & Gulf ............. & 97,474 & 0 & 156,449 & 0 & 253,923 \\
\hline & West Coast ........ & 4,388 & 0 & 0 & 0 & 4,388 \\
\hline \multirow[t]{2}{*}{ Kansas } & Gulf ............. & 5,663 & 0 & 0 & 0 & 5,663 \\
\hline & West Coast ........ & 92 & 0 & 0 & 0 & 92 \\
\hline Kentucky & Gulf ............. & 2,503 & 0 & 44,266 & 0 & 46,769 \\
\hline Louisiana . & Gulf ............. & 0 & 180 & 0 & 0 & 180 \\
\hline Maryland . & Atlantic .......... & 0 & 6,605 & 71 & 1,949 & 8,625 \\
\hline \multirow[t]{2}{*}{ Michigan } & Atlantic $\ldots \ldots \ldots$ & 19,835 & 0 & 0 & 0 & 19,835 \\
\hline & Lake ............. & 0 & 29,243 & 0 & 5,015 & 34,258 \\
\hline \multirow[t]{2}{*}{ Minnesota } & Lake ............. & 4,504 & 621 & 0 & 0 & 5,125 \\
\hline & Gulf............. & 25,508 & 0 & 75,594 & 0 & 101,102 \\
\hline Mississippi . & Gulf ............. & 0 & 216 & 0 & 0 & 216 \\
\hline Missouri ... & Gulf ............. & 2,099 & 0 & 28,450 & 0 & 30,549 \\
\hline \multirow[t]{2}{*}{ Nebraska } & Gulf ............. & 17,910 & 0 & 1,825 & 0 & 19,735 \\
\hline & West Coast ........ & 16,773 & 0 & 0 & 0 & 16,773 \\
\hline New Jersey & Atlantic .......... & 0 & 2,159 & 0 & 0 & 2,159 \\
\hline New York ....... & Atlantic $\ldots \ldots \ldots \ldots$ & 0 & 1,092 & 0 & 0 & 1,092 \\
\hline North Carolina .. & Atlantic & 1,904 & 16,034 & 2,348 & 0 & 20,286 \\
\hline North Dakota.. & Lake ............. & 208 & 40 & 0 & 0 & 248 \\
\hline \multirow[t]{3}{*}{ Ohio........ } & Atlantic $\ldots . . . \ldots$. & 114,147 & 963 & 0 & 0 & 115,110 \\
\hline & Lake ............. & 185 & 45,434 & 0 & 3,510 & 49,129 \\
\hline & Gulf............. & 0 & 0 & 28,230 & 0 & 28,230 \\
\hline Oklahoma.... & Gulf............. & 92 & 5 & 0 & 0 & 97 \\
\hline Pennsylvania...... & Atlantic $\ldots \ldots \ldots$ & 0 & 2,367 & 0 & 0 & 2,367 \\
\hline South Carolina .... & Atlantic ........... & 1,129 & 3,225 & 0 & 645 & 4,999 \\
\hline \multirow[t]{3}{*}{ South Dakota . } & Lake .............. & 654 & 73 & 0 & 0 & 727 \\
\hline & Gulf ............. & 383 & 221 & 0 & 0 & 604 \\
\hline & West Coast .......... & 458 & 0 & 0 & 0 & 458 \\
\hline Tennessee & Gulf $\ldots \ldots \ldots \ldots \ldots$ & 0 & 0 & 2,231 & 0 & 2,231 \\
\hline Texas ........... & Gulf ............. & 1,594 & 1,837 & 0 & 0 & 3,431 \\
\hline Virginia ......... & Atlantic .......... & 0 & 0 & 1,611 & 3,623 & 5,234 \\
\hline \multirow[t]{2}{*}{ Wisconsin .... } & Lake ............. & 4,515 & 14,706 & 0 & 8,461 & 27,682 \\
\hline & Gulf ............. & 0 & 0 & 3,350 & 0 & 3,350 \\
\hline \multirow[t]{3}{*}{ Great Lakes Ports . } & Lake .............. & 3,259 & 602 & 531 & 0 & 4,392 \\
\hline & Atlantic ........... & 2,202 & 0 & 0 & 0 & 2,202 \\
\hline & Gulf ............. & 1,496 & 0 & 6,814 & 0 & 8,310 \\
\hline Atlantic Ports ... & Atlantic $\ldots . . . \ldots$. & 0 & 95 & 0 & 0 & 95 \\
\hline Total receipts & 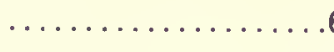 & 639,246 & 195,148 & 875,741 & 29,301 & $1,739,436$ \\
\hline Percentage of total & $\ldots \ldots \ldots \ldots$ & 36.7 & 11.2 & 50.3 & 1.7 & 100.0 \\
\hline
\end{tabular}

Note: Shipments between firms within a port area are excluded from these data. Shipments between port areas are shown separately from data for individual states of origin. 
received only 22.1 million bushels of corn in 1977 (excluding farm truck deliveries). All but 429,000 bushels of that amount moved by rail. Nebraska originated 76 percent of the total amount of corn that moved to the Pacific region. The pattern of port receipts is illustrated in Figure 3. Each state's share of receipts at all ports combined is shown in Figure 4. These data permit allocation of total exports to the states that originate shipments to port elevators. Export shipments originate from a relatively small number of states. The concentration is much greater than previous estimates have shown. For example, five states originate 84.5 percent of the total corn received at all U.S. port regions. Illinois is the source of 38.2 percent of corn received at all ports and 52.5 percent of the corn moving to the Gulf ports. Iowa ranks second, with 16.8 percent of the receipts at all ports and 22.8 percent of those at Gulf ports. Indiana, which ranks third as a source of receipts at all ports (12.3 percent), accounts for 42.7 percent of the receipts at Atlantic ports, fol- lowed by Ohio with 30.1 percent. Minnesota is also important in supplying the Gulf ports (9.1 percent) and accounted for 6.1 percent of corn received at U.S. ports in 1977. The estimated amount of corn received at all port areas in 1977 totalled 1.7 billion bushels, compared to 1.6 billion bushels that were inspected for export (Table 11). The remainder of the receipts were processed or reshipped to U.S. destinations. In general, barges were the predominant mode of transportation; they carried more than three-fourths of the corn received at the ports in the Gulf region. However, rail transportation at unit train rates also played a significant role in the movement of corn to the ports, especially to East Coast and West Coast ports.

\section{Destinations for U.S. Exports}

Corn shipped from the various origins to a specific port elevator is blended and stored on a commingled basis. Thus it is not possible to trace the movement

Table 11. 1977 Receipts of Com at Port Areas by Each Mode of Transportation

\begin{tabular}{|c|c|c|c|c|c|c|}
\hline \multirow{2}{*}{$\begin{array}{c}\text { Export region } \\
\text { and } \\
\text { port area }\end{array}$} & \multicolumn{4}{|c|}{ Mode of transportation } & \multirow[b]{2}{*}{ Total } & \multirow{2}{*}{$\begin{array}{l}\text { Inspections } \\
\text { for } \\
\text { export }^{\mathrm{b}}\end{array}$} \\
\hline & Rail & Truck & Barge & $\begin{array}{l}\text { Farm } \\
\text { truck }^{\mathrm{a}}\end{array}$ & & \\
\hline
\end{tabular}

thousands of bushels

\section{Great Lakes Region}

Duluth-Superior ............. 5,428

Chicago ................... 29,412

Toledo .................... 185

Saginaw ................... 19

Subtotal .................. $\overline{35,044}$

Atlantic Reglon

North Atlantic . . . . . . . . . . . 47,990

South Atlantic . . . . . . . . . . . . 289,357

Subtotal. . . . ............ . 337,347

\section{Gulf Reglon}

East Gulf . . . . . . . . . . . . . . . . 11,704

Louisiana Gulf . . . . . . . . . . . . . . . . 145,253

North Texas Gulf . . . . . . . . . . . 8 87,657

South Texas Gulf .............. . 530

Subtotal................... $\overline{245,144}$

Paclitic Region

Columbia River ................ 2, 2,83

Puget Sound .................. 8,477

California ................. 10,351

Subtotal ................. $\overline{21,711}$

Total receipts.

$.639,246$

$\begin{array}{r}758 \\ 76,687 \\ 75,455 \\ 3,576 \\ \hline 156,476\end{array}$

$\begin{array}{r}0 \\ 4,196 \\ 0 \\ 0 \\ \hline 4,196\end{array}$

$\begin{array}{r}0 \\ 8,556 \\ 9,153 \\ 0 \\ \hline 17,709\end{array}$

5,460

$\frac{28,439}{33,899}$

$\begin{array}{r}0 \\ 5,337 \\ \hline 5,337\end{array}$

$\begin{array}{r}0 \\ 6,217 \\ \hline 6,217\end{array}$

\section{2,101}

180

1,938

125

$\begin{array}{r}7,079 \\ 859,129 \\ 0 \\ 0 \\ \hline 866,208\end{array}$

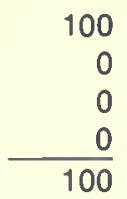

$\begin{array}{r}6,186 \\ 118,851 \\ 84,793 \\ 3,595 \\ \hline 213,425\end{array}$

$\begin{array}{r}5,526 \\ 48,403 \\ 84,933 \\ 3,576 \\ \hline 142,438\end{array}$

4,344
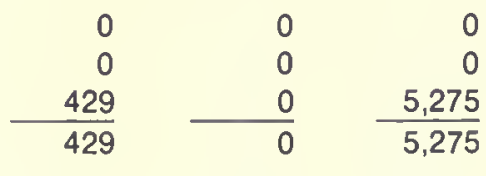

195,148

875,741

29,301

11.2

50.3

1.7

$\begin{array}{r}20,984 \\ 1,004,562 \\ 89,595 \\ 655 \\ \hline 1,115,796\end{array}$

\begin{tabular}{rr}
53,450 & 58,836 \\
329,350 & 299,087 \\
\hline 382,800 & 357,923 \\
& \\
20,984 & 19,035 \\
$1,004,562$ & 950,527 \\
89,595 & 91,766 \\
655 & 380 \\
\hline $1,115,796$ & $1,061,708$ \\
& 0 \\
2,883 & 0 \\
8,477 & 14,755 \\
16,055 & 14,755 \\
\hline 27,415 & $1,576,824$
\end{tabular}

100.0

Note: Shipments between firms within a port area are excluded from these data.

- This column reports receipts at elevators in each port area delivered directly from farmers.

' Inspections for export conducted under the United States Grain Standards Act and reported in Grain Market News, Agricultural Marketing Service, U.S. Department of Agriculture, Vol. 26, No. 2 (January 13, 1978), p. 18. 
Figure 3. Patterns of corn flow to port areas, 1977.

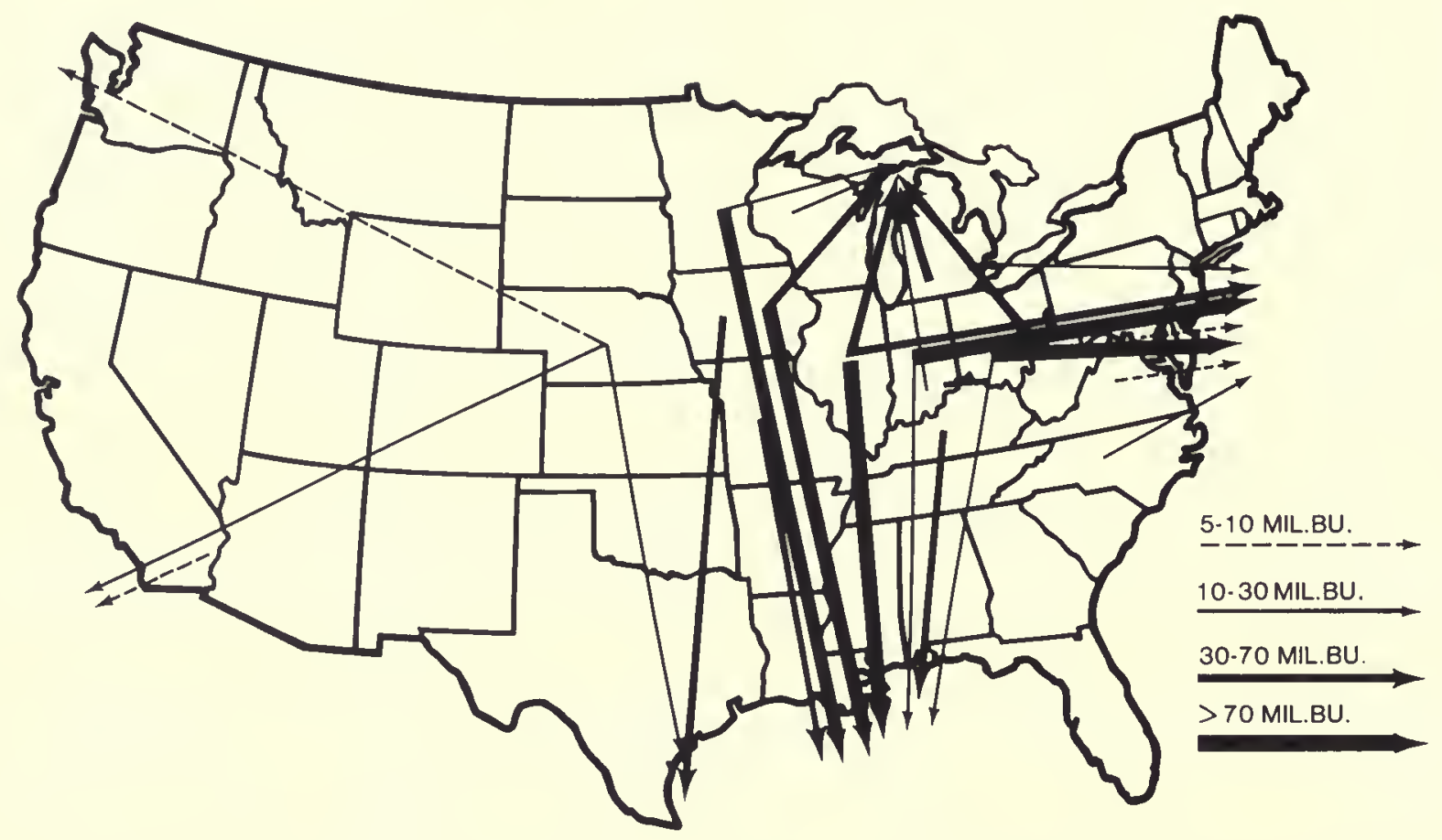

of corn from a particular state through the port system to its final destination, and therefore no attempt was made to determine whether a particular ocean vessel was loaded with, for example, Illinois corn or lowa corn. It is of interest, however, to examine one more link in the market chain that connects U.S. farmers with foreign feeders and processors. The destination countries for corn exported from the four export regions of the United States are shown in Table 12.

In 1977 the primary destination for corn exported through the Great Lakes was the United Kingdom. Most of the exports from the Atlantic port region went to Western Europe, primarily to Belgium, Spain, Portugal, and the United Kingdom. Corn exported from the Gulf port region went to the Netherlands and Japan. Japan received by far the largest amount of the U.S. corn shipped from the Gulf region, and it received more U.S. corn exports than any other nation. As indicated previously, almost no corn was exported from the Pacific region because of ocean back hauls to the Gulf, high ocean freight rates, and high rail rates for transporting corn to the Pacific region. Japan and Korea are the only nations that received com shipped from the Pacific export region.

\section{RECEIPTS AND SHIPMENTS BY AREA}

Estimates of the flow of corn by each mode of transportation and for every study area are presented in Tables 13-229. These estimates represent the most comprehensive and best data available on the volume of corn transported between each of the regions of the United States.

A detailed study of the flows will likely lead some readers to the conclusion that there are inefficiencies in the shipment of grain among states. Shipping corn in both directions between two states is one example of an apparent inefficiency in the marketing pattern. However, most of the shipments reported in this study reflect sellers' attempts to take advantage of profitable marketing opportunities that occur at a particular moment. It is not possible to provide a rationale for all of the movements without complete knowledge of daily price and transportation relationships. Local supply and demand vary throughout the marketing year, and buyers constantly seek the most economical supply source. Changes in supplies, demands, and transportation costs result in frequent changes in the most profitable shipping pattern. 
Figure 4. Proportion of 1977 corn movements to export regions from each originating state.

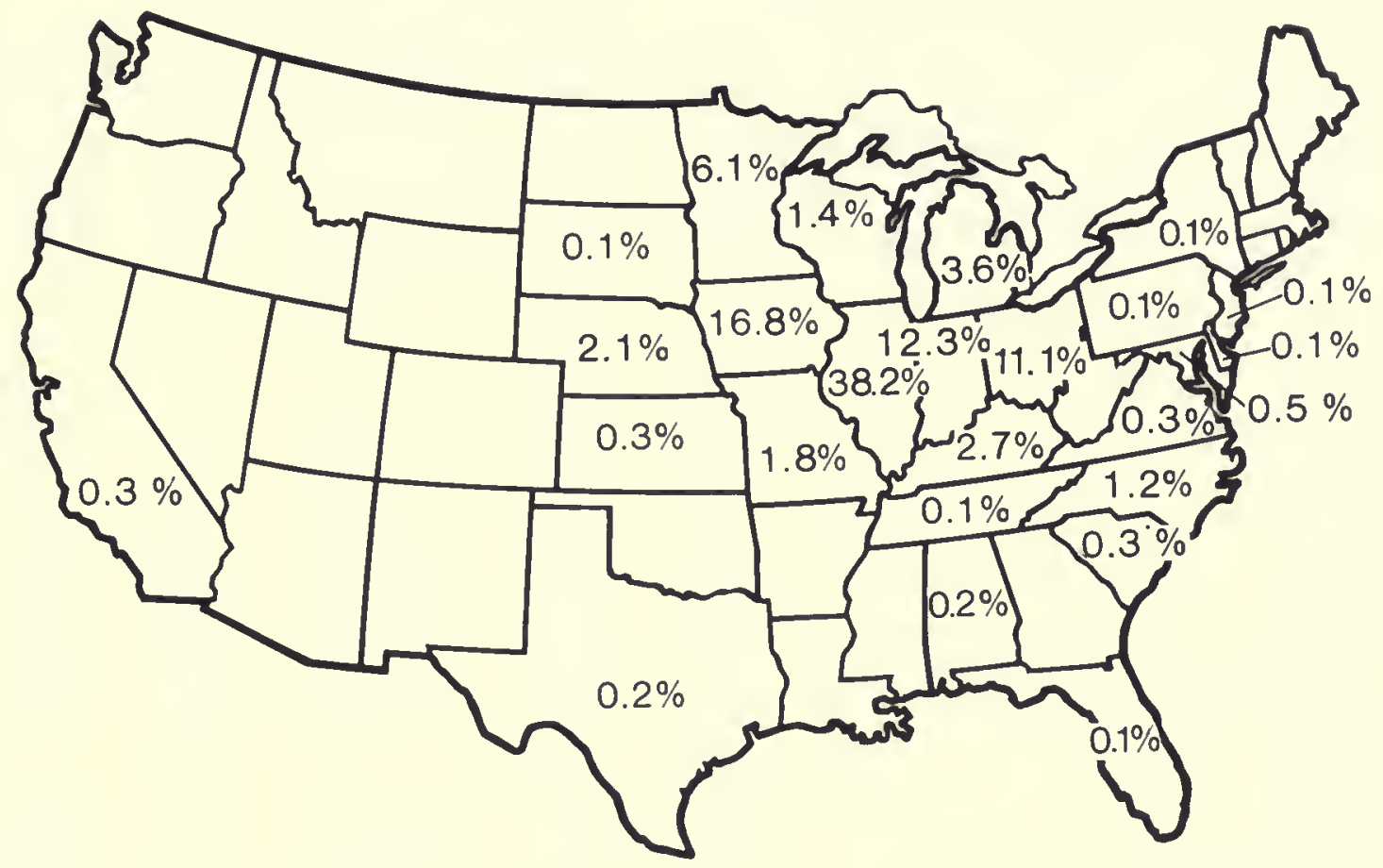

Table 12. 1977 Exports of U.S. Corn from Canada and the United States by Coastal Area and Dastination

\begin{tabular}{|c|c|c|c|c|c|c|}
\hline \multirow[b]{2}{*}{ Destination } & \multicolumn{5}{|c|}{ Export region } & \multirow[b]{2}{*}{ Total } \\
\hline & Canada & $\begin{array}{l}\text { Great } \\
\text { Lakes }\end{array}$ & Atlantic & Gulf & Pacific & \\
\hline & \multicolumn{6}{|c|}{ thousands of bushe/s } \\
\hline Algeria.... & 40 & 524 & 1,157 & 1,533 & 0 & 3,254 \\
\hline Azores ....... & 0 & 0 & 1,361 & 0 & 0 & 1,361 \\
\hline Barbados............ & 0 & 0 & 0 & 236 & 0 & 236 \\
\hline Belgium $\ldots \ldots \ldots \ldots \ldots$ & 539 & 2,117 & 37,102 & 42,147 & 0 & 81,905 \\
\hline Canada $\ldots . . \ldots \ldots \ldots \ldots$ & 0 & 11,266 & 0 & 0 & 0 & 11,266 \\
\hline Canary Islands ........... & 0 & 1,691 & 1,137 & 0 & 0 & 2,828 \\
\hline China, Rep. of (Taiwan) .... & 0 & 0 & 5,783 & 39,252 & 0 & 45,035 \\
\hline Colombia .............. & 0 & 0 & 0 & 4,044 & 0 & 4,044 \\
\hline Costa Rica .............. & 0 & 0 & 0 & 218 & 0 & 218 \\
\hline Cyprus ................. & 0 & 0 & 0 & 258 & 0 & 258 \\
\hline Czechoslovakia........... & 0 & 0 & 0 & 2,352 & 0 & 2,352 \\
\hline Dominican Rep. .......... & 0 & 0 & 232 & 3,492 & 0 & 3,724 \\
\hline Ecuador $\ldots \ldots \ldots \ldots \ldots$ & 0 & 0 & 0 & 413 & 0 & 413 \\
\hline Egypt $\ldots \ldots \ldots \ldots \ldots \ldots$ & 0 & 0 & 0 & 20,778 & 0 & 20,778 \\
\hline EI Salvador $\ldots . . . \ldots \ldots$. & 0 & 0 & 0 & 2,808 & 0 & 2,808 \\
\hline \multirow{2}{*}{ 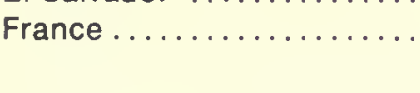 } & 751 & 2,575 & 6,151 & 2,227 & 0 & 11,704 \\
\hline & & & & & & Continued \\
\hline
\end{tabular}




\begin{tabular}{|c|c|c|c|c|c|c|}
\hline \multirow[b]{2}{*}{ Destination } & \multicolumn{5}{|c|}{ Export region } & \multirow[b]{2}{*}{ Total } \\
\hline & Canada & $\begin{array}{l}\text { Great } \\
\text { Lakes }\end{array}$ & Atlantic & Gulf & Pacific & \\
\hline & \multicolumn{6}{|c|}{ thousands of bushels } \\
\hline German Dem. Rep. (E) ..... & 3,764 & 0 & 0 & 2,738 & 0 & 6,502 \\
\hline Germany, Fed. Rep. of (W) . . & 2,810 & 3,779 & 13,425 & 92,550 & 0 & 112,564 \\
\hline Ghana $\ldots \ldots \ldots \ldots \ldots \ldots$ & 0 & 0 & 0 & 2,657 & 0 & 2,657 \\
\hline Greece................. & 286 & 660 & 22,581 & 14,113 & 0 & 37,640 \\
\hline Guatemala $\ldots \ldots \ldots \ldots \ldots$ & 0 & 0 & 0 & 1,066 & 0 & 1,066 \\
\hline Guyana $\ldots . \ldots \ldots \ldots \ldots$ & 0 & 0 & 0 & 104 & 0 & 104 \\
\hline Haiti $\ldots \ldots \ldots \ldots \ldots \ldots$ & 0 & 0 & 0 & 441 & 0 & 441 \\
\hline Honduras ... & 0 & 0 & 0 & 757 & 0 & 757 \\
\hline Iceland .. & 0 & 0 & 677 & 0 & 0 & 677 \\
\hline $\operatorname{Iran} \ldots \ldots \ldots \ldots \ldots \ldots$ & 0 & 0 & 2,399 & 1,083 & 0 & 3,482 \\
\hline Iraq $\ldots \ldots \ldots \ldots \ldots \ldots \ldots$ & 0 & 0 & 0 & 433 & 0 & 433 \\
\hline Ireland $\ldots \ldots \ldots \ldots \ldots \ldots$ & 0 & 0 & 820 & 34 & 0 & 854 \\
\hline Israel $\ldots \ldots \ldots \ldots \ldots \ldots$ & 0 & 0 & 2,399 & 11,628 & 0 & 14,027 \\
\hline Italy $\ldots \ldots \ldots \ldots \ldots \ldots$ & 1,907 & 0 & 16,017 & 60,016 & 0 & 77,940 \\
\hline Jamaica ................. & 0 & 0 & 106 & 6,772 & 0 & 6,878 \\
\hline Japan ................. & 98 & 553 & 15,233 & 272,193 & 12,389 & 300,466 \\
\hline Korea, Rep. of ........... & 2,219 & 0 & 14,581 & 33,692 & 2,366 & 52,858 \\
\hline Lebanon $\ldots \ldots \ldots \ldots \ldots \ldots$ & 0 & 600 & 330 & 0 & 0 & 930 \\
\hline Liberia .................. & 0 & 0 & 0 & 40 & 0 & 40 \\
\hline Malta $\ldots \ldots \ldots \ldots \ldots \ldots$ & 0 & 956 & 0 & 0 & 0 & 956 \\
\hline Mexico $\ldots \ldots \ldots \ldots \ldots \ldots$ & 0 & 0 & 0 & 63,631 & 0 & 63,631 \\
\hline Netherlands ............. & 1,420 & 4,501 & 7,373 & 167,811 & 0 & 181,105 \\
\hline Netherland Antilles ....... & 0 & 0 & 0 & 153 & 0 & 153 \\
\hline Nicaragua...$\ldots \ldots \ldots \ldots$ & 0 & 0 & 0 & 1,054 & 0 & 1,054 \\
\hline Nigeria .................. & 1,068 & 40 & 0 & 2,281 & 0 & 3,389 \\
\hline Norway $\ldots \ldots \ldots \ldots \ldots$. & 0 & 0 & 880 & 1,288 & 0 & 2,168 \\
\hline Panama...$\ldots \ldots \ldots \ldots$ & 0 & 0 & 0 & 112 & 0 & 112 \\
\hline Peru $\ldots \ldots \ldots \ldots \ldots \ldots \ldots$ & 0 & 0 & 0 & 6,735 & 0 & 6,735 \\
\hline Philippines ............. & 0 & 0 & 420 & 5,026 & 0 & 5,446 \\
\hline Poland...$\ldots \ldots \ldots \ldots$ & 316 & 618 & 16,024 & 39,522 & 0 & 56,480 \\
\hline Portugal ................ & 0 & 0 & 48,810 & 18,075 & 0 & 66,885 \\
\hline Rhodesia ............. & 0 & 0 & 0 & 152 & 0 & 152 \\
\hline Romania $\ldots \ldots \ldots \ldots \ldots$ & 0 & 0 & 6,492 & 4,871 & 0 & 11,363 \\
\hline Saudi Arabia $\ldots . . \ldots \ldots \ldots$ & 0 & 0 & 0 & 243 & 0 & 243 \\
\hline Sierra Leone ............. & 0 & 0 & 0 & 10 & 0 & 10 \\
\hline Singapore $\ldots \ldots \ldots \ldots \ldots$ & 0 & 0 & 0 & 671 & 0 & 671 \\
\hline Spain ................... & 39,962 & 1,621 & 37,441 & 9,391 & 0 & 88,415 \\
\hline Surinam $\ldots \ldots \ldots \ldots \ldots$ & 0 & 0 & 0 & 907 & 0 & 907 \\
\hline Syria................... & 0 & 0 & 538 & 0 & 0 & 538 \\
\hline Tanzania ............... & 0 & 0 & 0 & 1,314 & 0 & 1,314 \\
\hline Thailand $\ldots \ldots \ldots \ldots \ldots \ldots$ & 0 & 0 & 0 & 217 & 0 & 217 \\
\hline Trinidad $\ldots \ldots \ldots \ldots \ldots$ & 0 & 0 & 191 & 2,149 & 0 & 2,340 \\
\hline Tunisia ................ & 866 & 0 & 0 & 1,651 & 0 & 2,517 \\
\hline United Kingdom ........... & 6,380 & 38,757 & 46,950 & 22,304 & 0 & 114,391 \\
\hline U.S.S.R............... & 3,457 & 6,297 & 51,313 & 87,210 & 0 & 148,277 \\
\hline Venezuela............... & 0 & 0 & 0 & 4,855 & 0 & 4,855 \\
\hline Total $\ldots \ldots \ldots \ldots \ldots \ldots$ & 65,883 & 76,555 & 357,923 & $1,061,708$ & 14,755 & $1,576,824$ \\
\hline
\end{tabular}

Source: Grain Market News, Agricultural Marketing Service, U.S. Department of Agriculture, Vol. 26, No. 5 (February 3, 1978). 
The availability of storage space at harvest time is also an important factor in determining corn shipments. If local storage facilities are filled with wheat when corn moves from the farms, country elevators may be forced to ship corn to various terminal or processing locations for storage. Later in the year supplies in the local region may be exhausted, and feed mills and livestock feeders in that area will begin purchasing com from outside sources, reversing the earlier outbound flow. Many other factors, such as the availability of transportation, have a substantial impact on corn movements. Restrictions on rail shipments during periods of peak movement may force corn to flow to destinations that would not otherwise be the most economical. A detailed analysis of the influence of these factors is beyond the scope of this publication. Readers interested in more detailed information about corn movements, the types of firms involved, and the seasonality of these movements should contact Agricultural Experiment Station representatives in the participating states. 


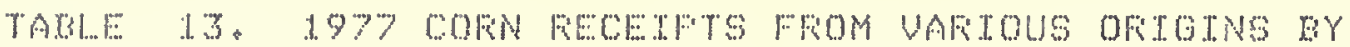

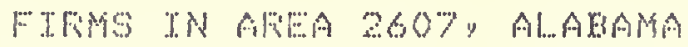

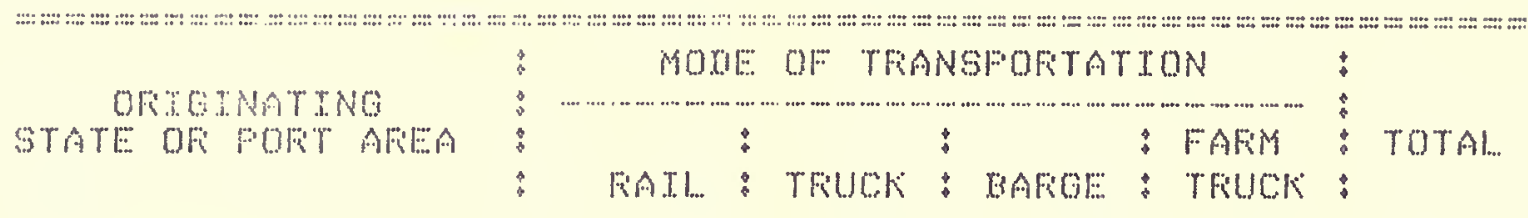

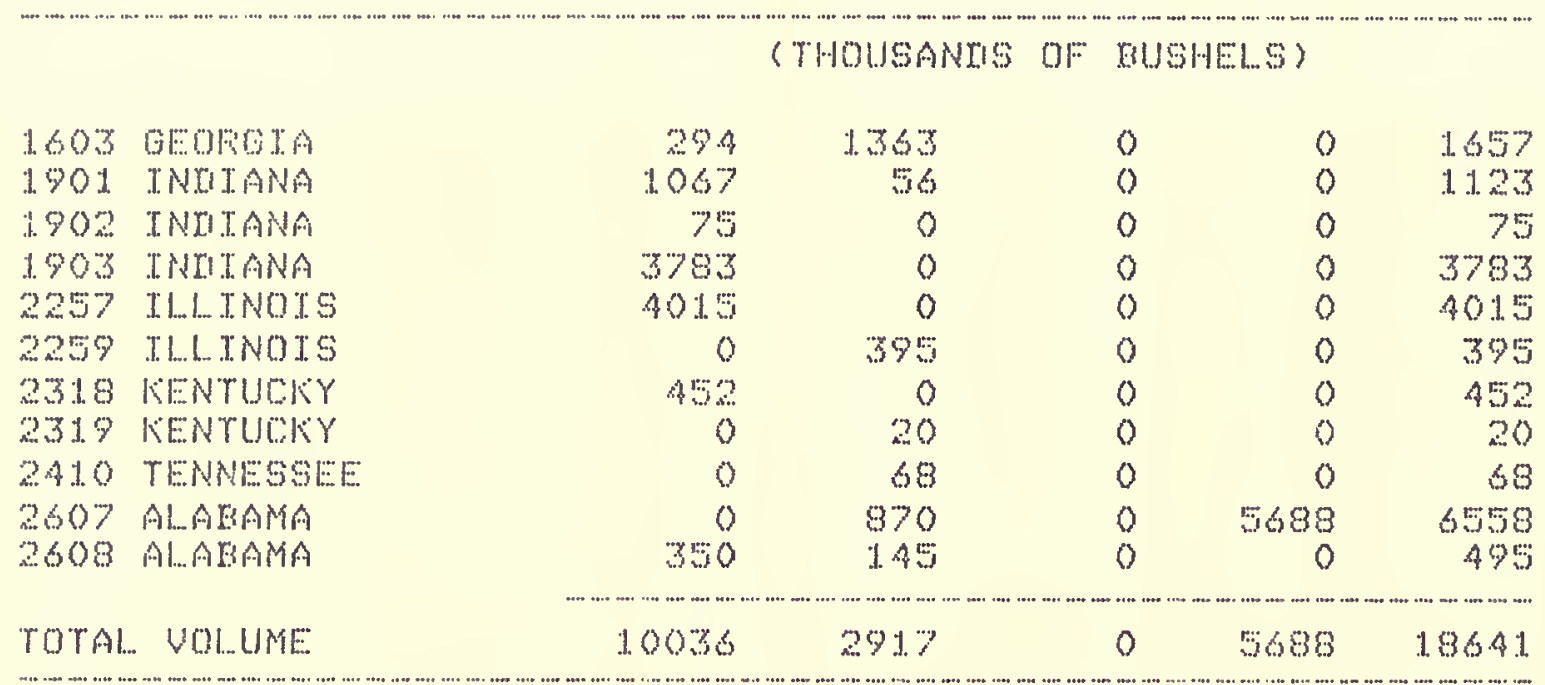

TAELE 14. $197 \%$ COFW SHFMENT TO UAFTOUS TESTTNATTONS BY FTKMS IN ANEA 2607 , ALABAMA

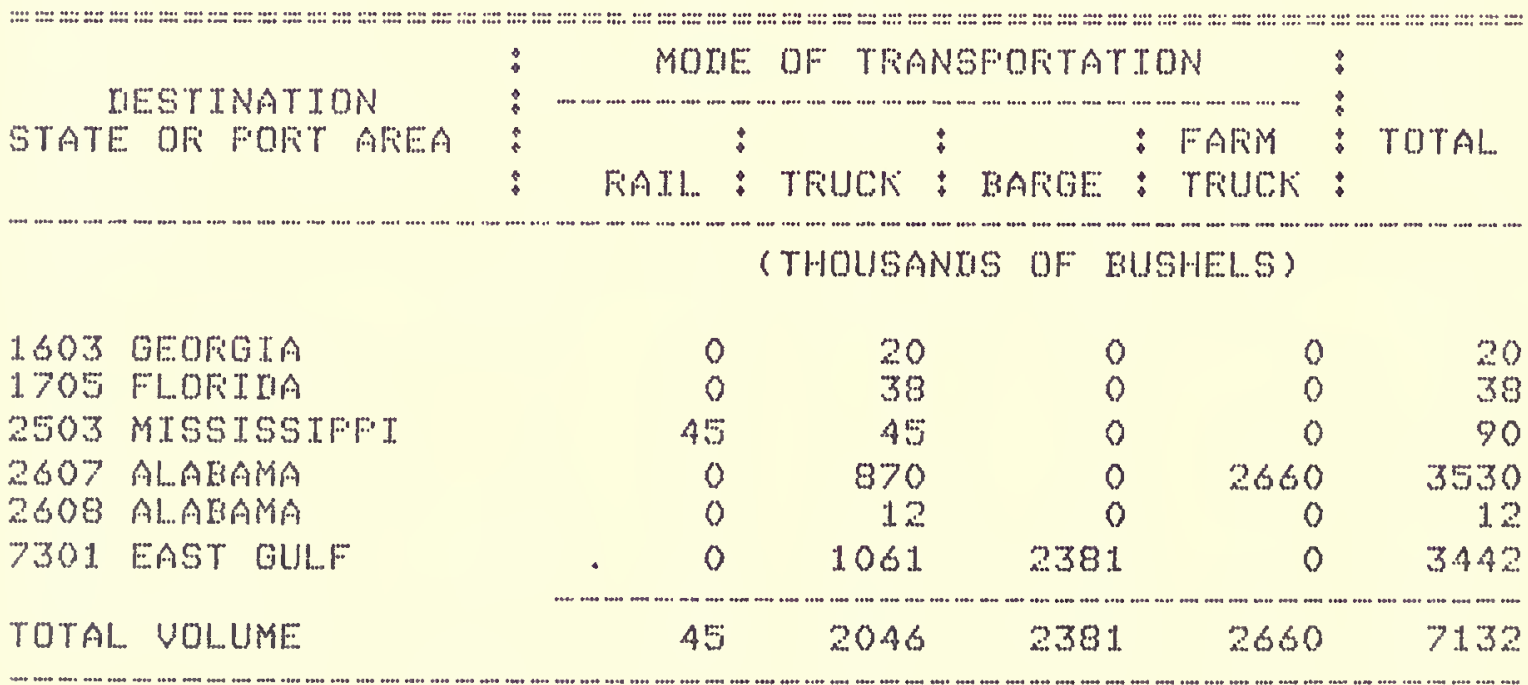


TABLE 15.1977 COFIN FECEIFTS FFOM UAFIOUS OFIOTNS IBY FIFMS IN AFEA 2603, ALADAMA

\begin{tabular}{|c|c|c|c|c|c|c|}
\hline \multirow{3}{*}{$\begin{array}{c}\text { OFIGINATTNG } \\
\text { STATE OF FOFT AFEA }\end{array}$} & MORIE OF & E OF TFAN & \multicolumn{2}{|c|}{ TFANSFOFTATTON } & \multirow{3}{*}{$\vdots$} & \multirow{3}{*}{$\operatorname{Tot} A$ L.. } \\
\hline & $:$ & $:$ & : & : FAFM & & \\
\hline & FiAIL. & : TFUCK & : EARGE & : TRUCK & & \\
\hline & & (THOUSAT & Nris of kis & (USWE1..5) & & \\
\hline 1609 GEOFGTA & 145 & 1.33 & 0 & 0 & & 278 \\
\hline 18200410 & 0 & 0 & 2678 & 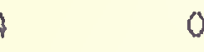 & ) & 2574 \\
\hline 1901 INIIANA & 6956 & $48 \%$ & 0 & 0 & ) & 7438 \\
\hline 1902 INIIANA & 267 & 0 & 0 & ) & 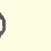 & 267 \\
\hline TNIIIANA & 2076 & 43 & 9424 & 0 & ) & 11743 \\
\hline IIII INOIS & 2433 & 0 & 4701 & 0 & ) & 7.1 .34 \\
\hline 2257 TLLLINOIS & 12499 & 0 & 0 & ) & 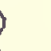 & 1.2499 \\
\hline 2258 IILLINOTS & 23.4 & 0 & 0 & 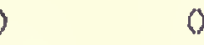 & 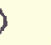 & 2.34 \\
\hline 2259 TII. TNOIS & $116 \%$ & 3220 & 2000 & 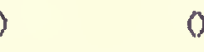 & ) & 6381 \\
\hline 2260 TILLINOTS & 0 & 0 & 2299 & 8 & ) & 2299 \\
\hline 2261 IILINOTS & 0 & 0 & 3162 & 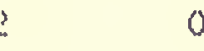 & ) & 3162 \\
\hline 2062 TILL TNOIS & 836 & 0 & 0 & 0 & ) & 836 \\
\hline 2270 TLIIINOIS & 2000 & 0 & 0 & ) & ) & 2000 \\
\hline 2318 KENTUCKY & 2775 & 1.03 & 2064 & 4 & 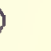 & 4942 \\
\hline 2319 KEENTUCKY & 62 & 381 & 0 & ) & ) & 4.43 \\
\hline 2410 TENNESSEE & 0 & 376 & 0 & 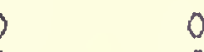 & 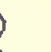 & 376 \\
\hline 2A11 TENNI:-SSI::E & 0 & $8 \%$ & 0 & b & 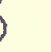 & 87 \\
\hline 2412 TENNESSEE & 0 & 332 & 0 & 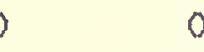 & 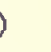 & 332 \\
\hline 2502 MISSISSIFFI & 0 & 40 & 0 & 0 & & 40 \\
\hline 2607 ALABAMA & 0 & i. 2 & 0 & 82 & & 94 \\
\hline 2608 ALABAMA & 968 & $108: 88$ & 62\% & 1505 & & 1.3958 \\
\hline 2700 MINNESOTA & 0 & 0 & 430 & 0 & 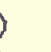 & 430 \\
\hline 2801 IOWA & 1.2 & 0 & 0 & 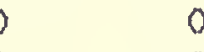 & 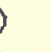 & 12 \\
\hline 2803 IOWA & 0 & 0 & 354 & 7 & 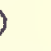 & 354 \\
\hline 2900 MTSS0UFI & 0 & 0 & 1350 & 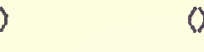 & ) & 1.350 \\
\hline TOTAL VOLUME & $\times 2624$ & 16067 & 28985 & 1.587 & & 79263 \\
\hline
\end{tabular}


TAILE 16. 1977 COKN SHTFPENTS TO VARTOUS TIESTINATIONS RY FIFMS IN AFEA 2608, ALABAMA

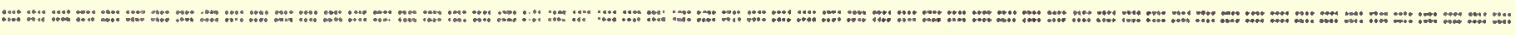

DEETTNATION

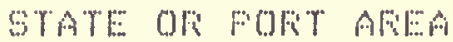

MODE OF TEANSFOFTATION

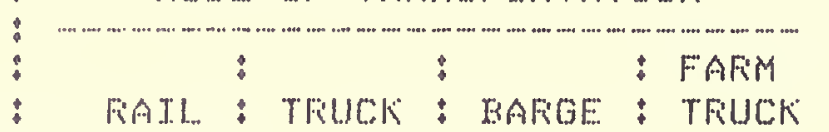

(THOUSANLS OF" BUSHEISS)
1.603 GEORGTA

2A10 TENNESSEE

2411 TENNESSI:E

2503 MISSTSSIFHT

2607 AL...ABAMA

2608 ALABAMA

TOTAL.. VOLUME:
$0 \quad 1012001012$ COMATNEX TO AVOII IISCLOSUFE 50

\begin{tabular}{rrrrr}
0 & 29 & 0 & 0 & 29 \\
350 & 145 & 0 & 0 & 495 \\
968 & 10858 & 627 & 935 & 13388 \\
\hline 1310 & 12086 & 677 & 935 & 15016
\end{tabular}

TAELE 17. 1977 COFN RECETFTS FFOM VAFTOUS OFTGTNS RY FTMS TN AFEA 4400 , AFIZZONA

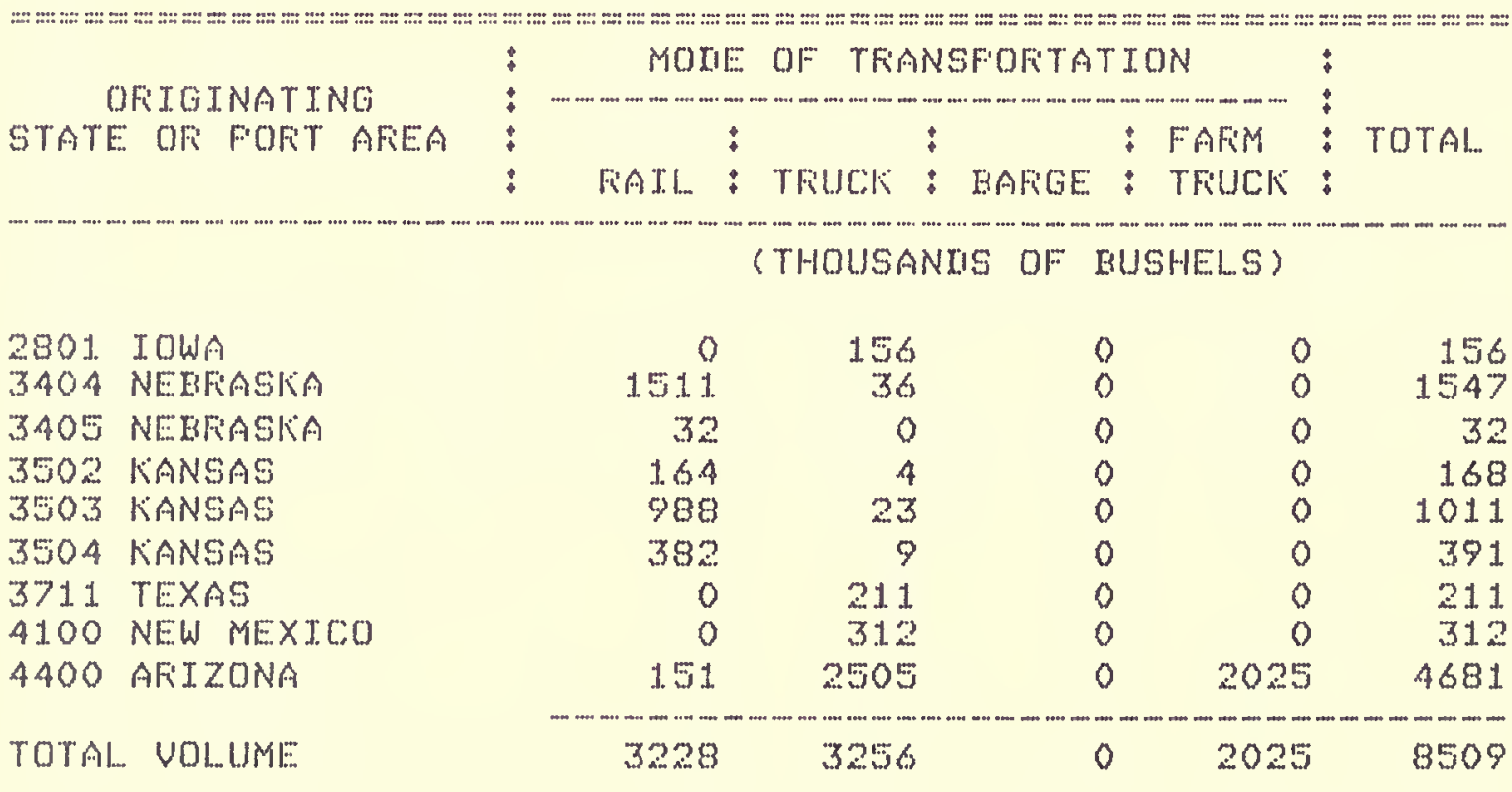


TAELE 18. 1977 COFN SHIFMENTS TO VARTOUS DESTINATTONS BY FIFMS IN AFEEA AAOOY AFIZONA

:

DIESTINATION

STATE: OF PORT AFIEA
MOIE OF THANSFORTATION

: FAFIM

RATL: TFUCK： BAFEE: : TFUUKK:

rotal...

(THOUSANIS OF BUSHELS)

4400 AFIZONA

TOTAL. VOI... UME:

$\begin{array}{ccccc}151 & 2505 & 0 & 0 & 2656 \\ 151 & 2505 & 0 & 0 & 2656\end{array}$

TABHE 19. 1977 COFN RECETFTS FFOM UAFTOUS OFIGINS BY FTLMS TN AFEEA 3005 Y AFK ANSAS

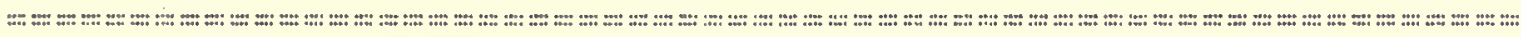

OFIGINATTNG

STATE OF FOFT AFEA
MOIE: OF TFANSFOFTATION

$\vdots$

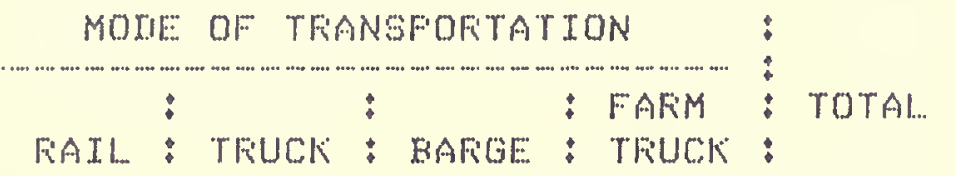

(THOUSANIS OF BUSHELS)

$\begin{array}{lrrrrrr}2258 & \text { ILLINOIS } & 342 & 0 & 0 & 0 & 342 \\ 2801 & \text { IOWA } & 904 & 0 & 0 & 0 & 804 \\ 3016 \text { AFKANSAS } & 15124 & 3782 & 0 & 0 & 19906 \\ 3405 \text { NEFFASKA } & 117 & 0 & 0 & 0 & 117 \\ 3503 \text { KIANSAS } & 1547 & 0 & 0 & 0 & 1547 \\ 3505 \text { KKANSAS } & 66 & 0 & 0 & 0 & 66 \\ \text { TOTAL WOLUME } & 18000 & 3782 & 0 & 0 & 21782\end{array}$

TAFLE 20, 1977 COFN FECETFTS FFOM UAFIOUS DFIGINS BY FIFIMS IN AFIEA 3016 Y AFIKANSAS

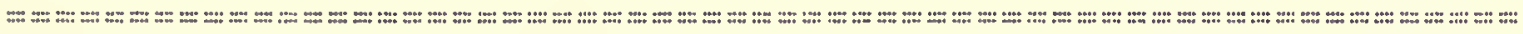

OFIGINATING

STATE DF FDFT AFEA

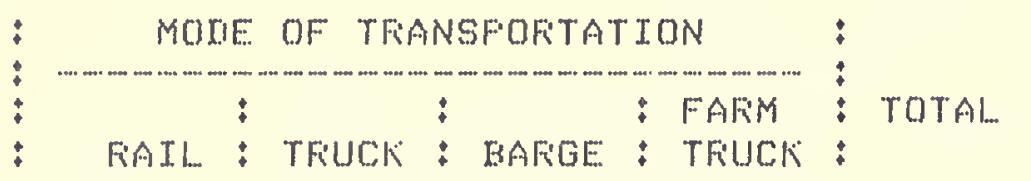

(THOUSANIS OF BUSHEI.S)

2258 ILLINOIS
2801 IOWA
2802 IOWA
2801 MISSOUFI
3404 NEBFIASKIA
3405 NEEFASKIA
3503 KIANSAS
3505 KIANSAS

TOTAL VOLUME

$\begin{array}{rrrrr}0 & 183 & 0 & 0 & 183 \\ 9061 & 4567 & 0 & 0 & 13628 \\ 3774 & 0 & 0 & 0 & 3774 \\ 6110 & 0 & 0 & 0 & 6110 \\ 7740 & 0 & 0 & 0 & 7740 \\ 18490 & 1477 & 0 & 0 & 19967 \\ 7970 & 0 & 0 & 0 & 7970 \\ 620 & 0 & 0 & 0 & 620\end{array}$

183

3774

6110

7740

7970

620 
TABLE 21. 1977 COFN SHIFMENTS TO UAFIOUS IIESTINATIONS BY FIRMS IN AFEA 3016, ARKAANSAS

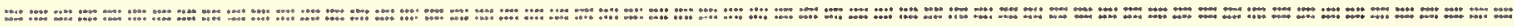

IIESTTNATTON

STATE OF FORT AREA
MOLE OF TFANGFOFTATION

$\vdots$

RATL: TFUCK: : BAFEE: FAFU : TFUKK:

TOTAL

\begin{tabular}{|c|c|c|c|c|c|}
\hline $\begin{array}{l}3005 \text { AFKANSAS } \\
3038 \text { ARKANSAS }\end{array}$ & $\begin{array}{r}15124 \\
916\end{array}$ & $\begin{array}{r}3782 \\
916\end{array}$ & $\begin{array}{l}0 \\
0\end{array}$ & 0 & $\begin{array}{r}18906 \\
1832\end{array}$ \\
\hline OTAL VOLUME & 16040 & 4698 & 0 & 0 & 20738 \\
\hline
\end{tabular}

TARIIE 22. $197 \%$ COFN FECFIPTS FFOM UAFIOUS OFIGINS BY FTFMS IN AFEA 3017 y AFK゙ANSAS

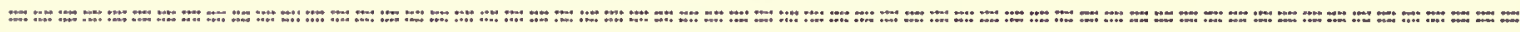

ORYTENAT TNE:

STATE OK FOFT AFEA

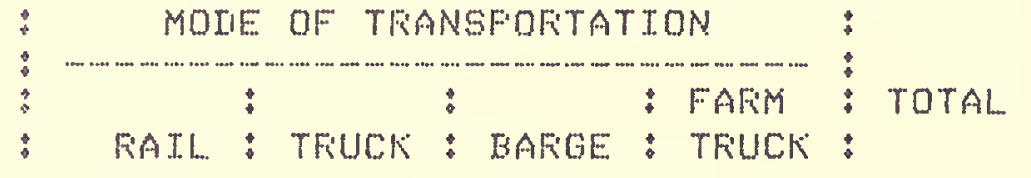

(THOUSANIIS OF EUSHELS)

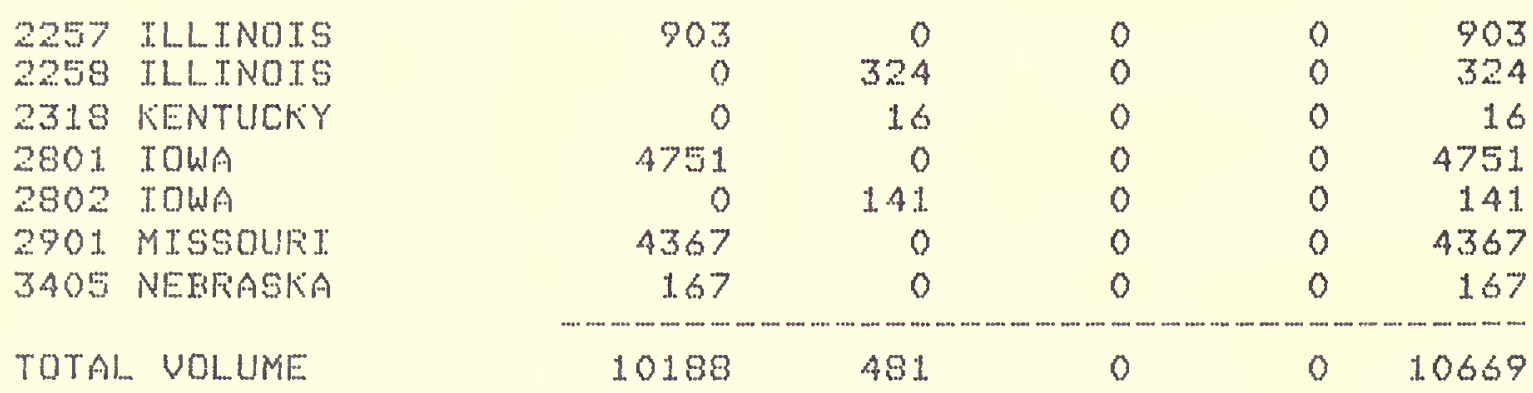

TABLEF 23. 1977 CORN SHIFMENTS TO UAFTOUS IIESTTNATTONS BY FIFMS IN AFEA 3017\% AFKANGAS

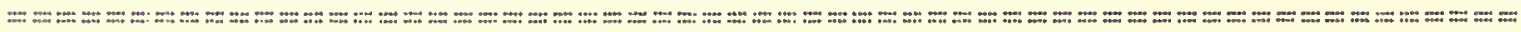

DESTINATION STATE OF FOFT AFEA
MOLE OF TFANSFOFTATION

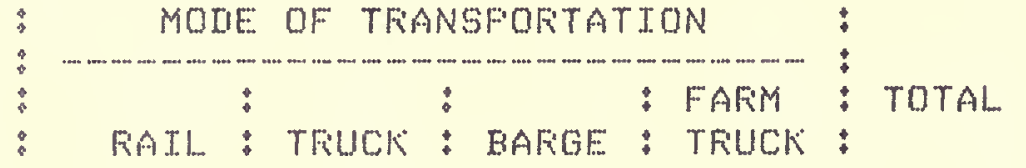

(THOUSANIS OF EUSHELS)
3038 AFKANSAS

TOTAL VOLUME

\begin{tabular}{ccccc}
0 & 385 & 0 & 0 & 385 \\
\hline 0 & 385 & 0 & 0 & 385
\end{tabular}


TARLE 24. 1979 COFN FECETETS FFOM UAFIOUS OFIGTNS BY FIFMS IN AFEA 3038 y AFKIANSAS

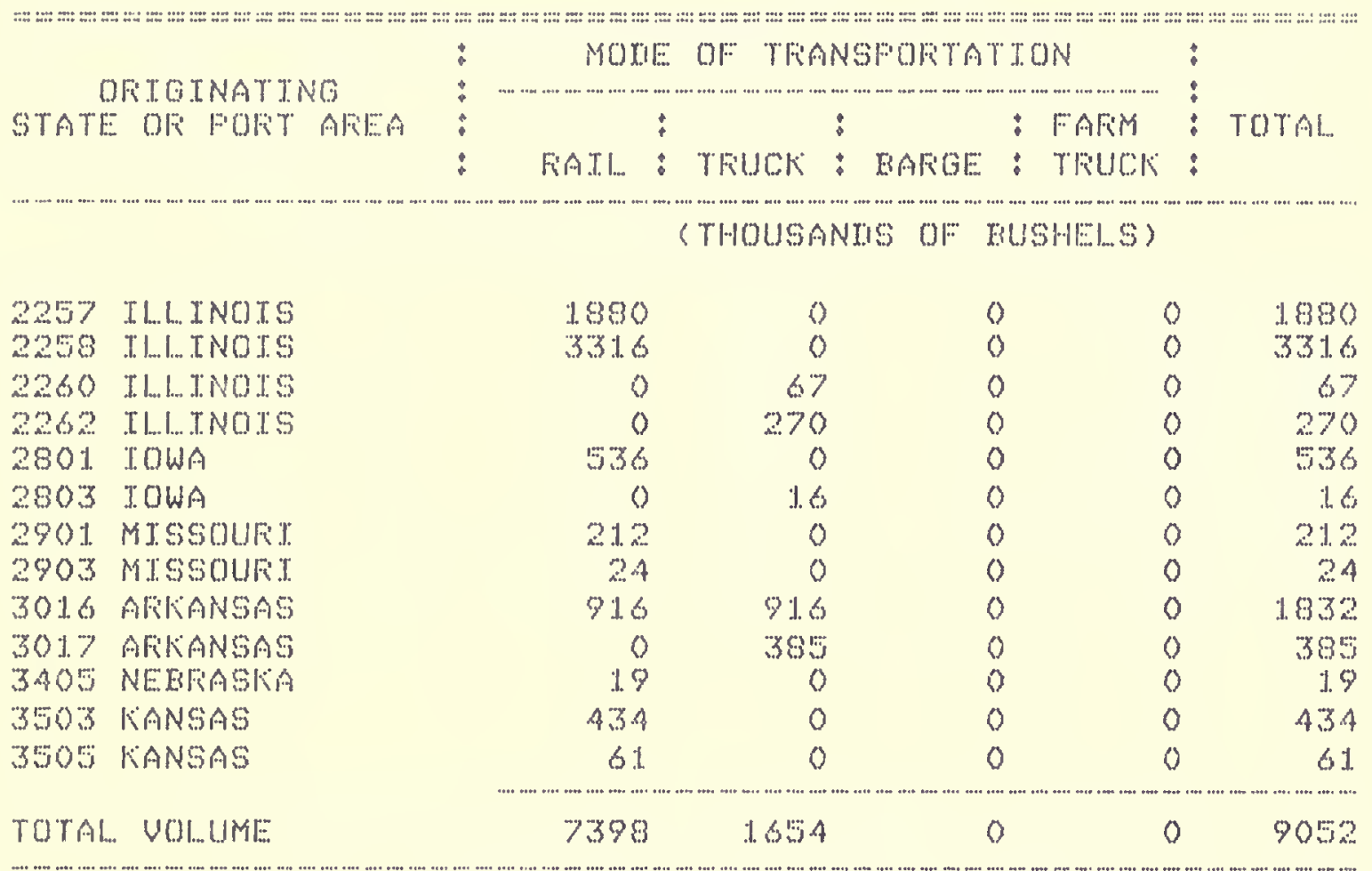

TABLE 2E. 1977 COFN SHTFENTS TO VAROUS IESTINATTONG RY FIFMS IN AFEA 3039 Y AFKANSAS

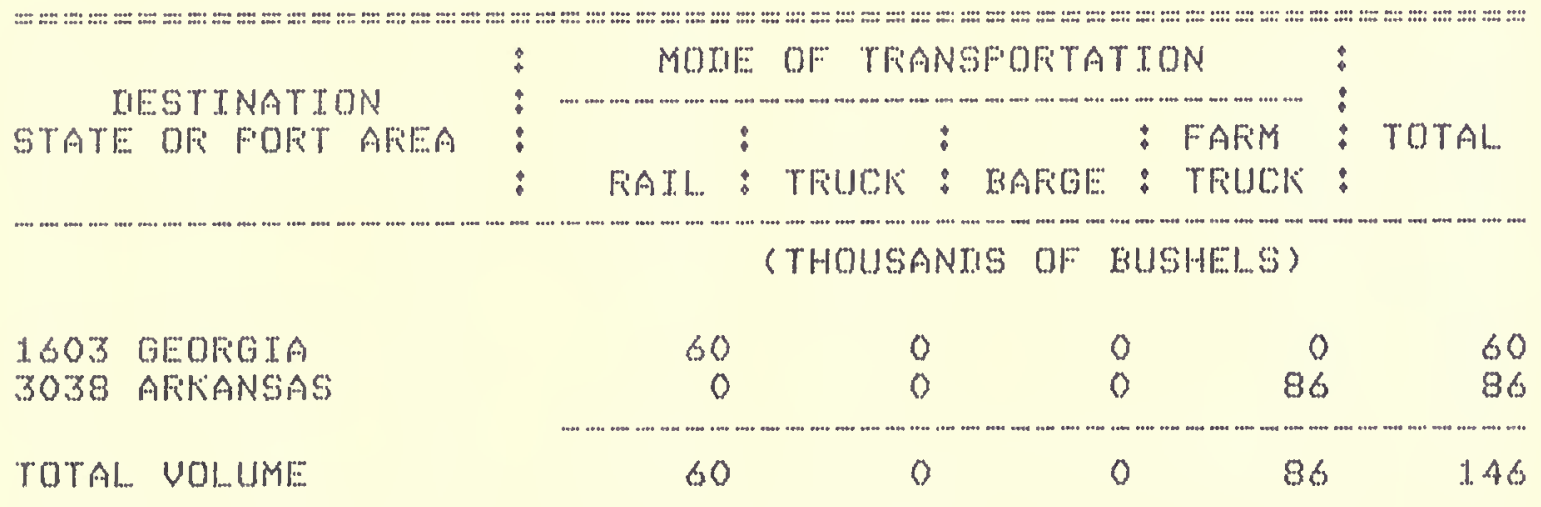


TAELE 26. 1977 COFN RECETWTS FFOM UARTOUS OFICINS BY FIRMS TN AFEA A7OJ, CALIFOFNTA

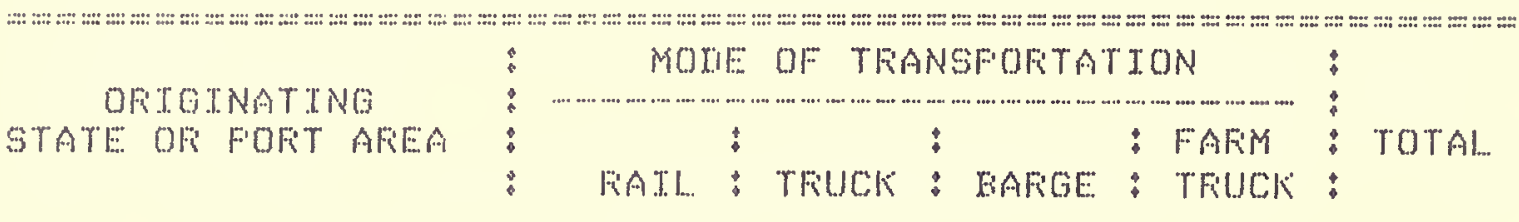

(THOUSANDS OF EUSHELS)

\begin{tabular}{|c|c|c|c|c|c|c|}
\hline $\begin{array}{l}3401 \\
3404\end{array}$ & $\begin{array}{l}\text { NEEEASK゙A } \\
\text { NEBRASK゙A }\end{array}$ & $\begin{array}{r}700 \\
1.3422\end{array}$ & $\begin{array}{l}0 \\
0\end{array}$ & 0 & $?$ & $\begin{array}{r}750 \\
1.3442\end{array}$ \\
\hline 3002 & KAANSAS & 73 & 0 & 0 & 0 & 73 \\
\hline 371.2 & TEXAS & 3161 & 0 & 0 & 0 & 3161 \\
\hline 4000 & COLOFAXO & 6208 & 0 & 0 & 0 & 6208 \\
\hline 4703 & CAILIFOFNTA & 0 & 1905 & 0 & 2024 & 3929 \\
\hline OTAL & UOI..LME & 23634 & 1905 & 0 & 2024 & 27563 \\
\hline
\end{tabular}

TABLE 27. $197 \%$ CORN FECETHS FFOM VARTOUS OFTGTNS BY FIFMS IN AFEA 4703 , CALITFOFNTA

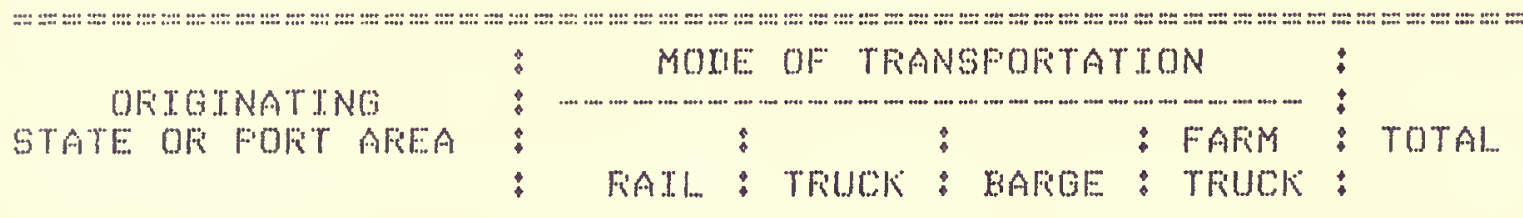

(THOUSANDS OF EUSHELS?

3401 NEBFASKA

340A NEBFSASKIA

3405 NEEFIASIIA

302 KANSAS

3504 KANSAS

371.1 TEXAS

3712 TEXAS

$376 \%$ TEXAS

4000 COLOFALO

4703 CAL TFOFIIA

TOTAL VOLUME:
1.71 .5

34891

$117 \%$

69

24

2193

404

213

60

$\begin{array}{ccccc}0 & 18649 & 0 & 40840 & 59489 \\ 40734 & 19190 & 0 & 40840 & 100764\end{array}$


TAELE 28. 1977 CORN SHJFMENTS TO UARTOUS IESTINATTONS BY FTFMS IN AFEA 9703 Y CALJFOFNTA

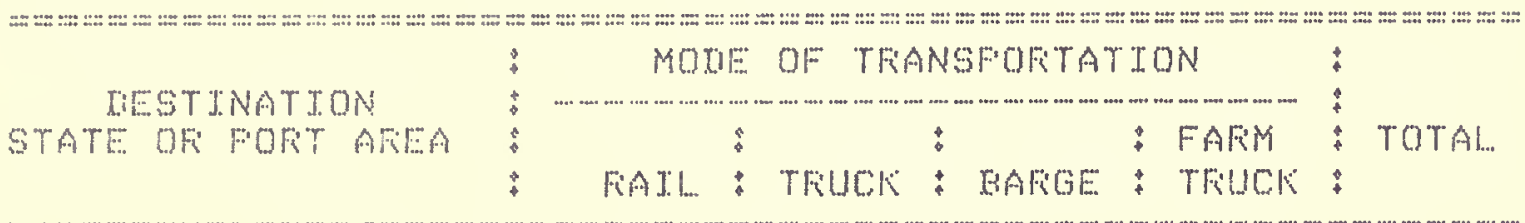
(THOUSANMS OF MUSHEISS)

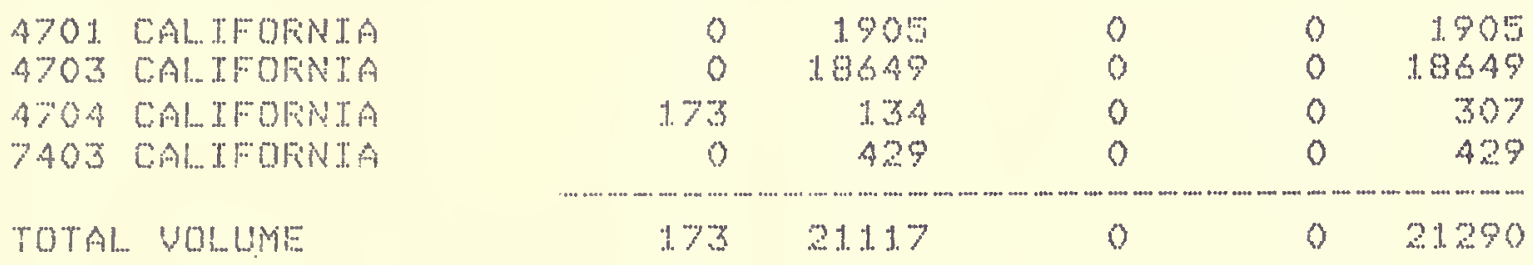

TABHE 29. $797 \%$ CORN REOETHS FROM UARTOU ORTOINS BY FTRY IN AREA A7OA, CALIFOFNTA

OFTGINATTNG
STATE OF FOFT AFEA




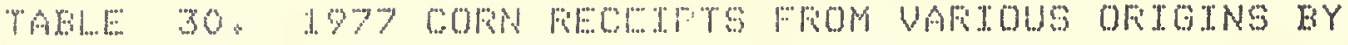

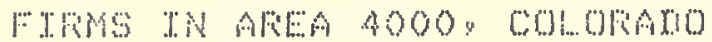

\begin{tabular}{|c|c|c|c|c|c|c|}
\hline & : & MOII:: & Tirí & NGOKOA & TON & $\ddagger$ \\
\hline ondolmardis & $\stackrel{i}{i}$ & $(\cdots+\ldots \ldots+\ldots+\cdots \cdots+\cdots$ & (............................ & (........................... & $\ldots \ldots \ldots \ldots \ldots \ldots, \cdots \cdots$ & $:$ \\
\hline 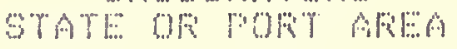 & : & \& & & 3 & FAMM & '0YAL... \\
\hline & $:$ & WAsti... & TFUKK & \& $\mathrm{Am}$ & : YFUCA & : \\
\hline
\end{tabular}

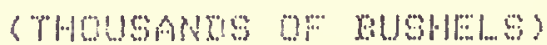

3401 NEDFARA

3402 NEERASKA

3403 NEBFAGKA

3.404 NEEFASKA

$340 \%$ NEERASKA

$3 \%$ KO KANSAS

4000 COHORTOL

TOTAL VOI.. UME

$\begin{array}{rrrrr}0139 & 1471 & 0 & 0 & 9610 \\ 198 & 0 & 0 & 0 & 198 \\ 12 & 0 & 0 & 0 & 12 \\ 26002 & 0 & 0 & 0 & 26002 \\ 1268 & 472 & 0 & 0 & 1740 \\ 234 & 908 & 0 & 0 & 1142 \\ 89 & 7932 & 0 & 0 & 7621 \\ 36992 & 10383 & 0 & 0 & 46326\end{array}$

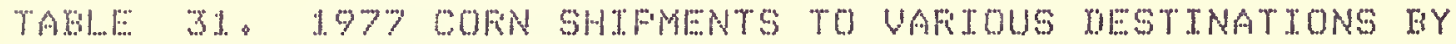
FIFG IN AREA 4000 \% COLORMLO

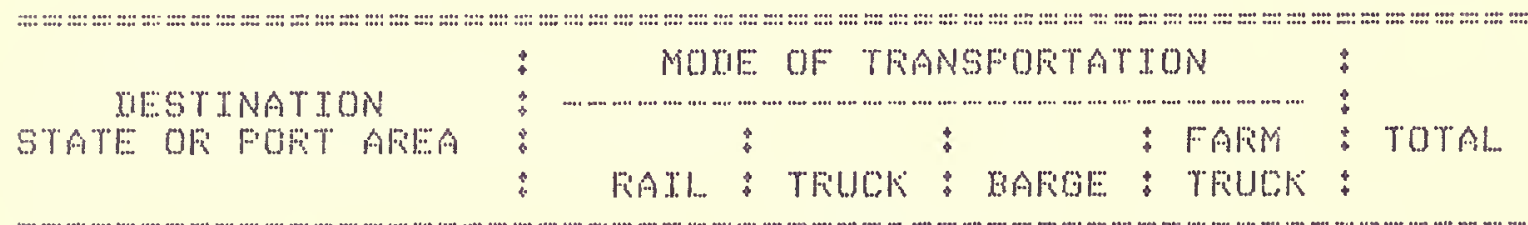

\section{(THOUSANMS OF RUSHEIS)}

\begin{tabular}{|c|c|c|c|c|c|c|}
\hline $360 ?$ & OKILANOMA & 1.4 & 1.96 & 0 & 0 & 210 \\
\hline 3711 & TEXAS & $1: 5$ & 1458 & 0 & 0 & 1473 \\
\hline 4000 & COI..OFADO & $8 \%$ & 7532 & 0 & 0 & 7621 \\
\hline $\begin{array}{l}4300 \\
4701\end{array}$ & $\begin{array}{l}\text { UTAH } \\
\text { CAL THOFNIA }\end{array}$ & $\begin{array}{r}972 \\
6208\end{array}$ & $\begin{array}{r}399 \\
0\end{array}$ & 0 & 0 & $\begin{array}{l}1.371 \\
6208\end{array}$ \\
\hline $4 \% 03$ & CALIFOKNIA & 60 & 0 & 0 & 0 & 60 \\
\hline orml. & VOLLUME & 7368 & 9585 & 0 & 0 & 16943 \\
\hline
\end{tabular}




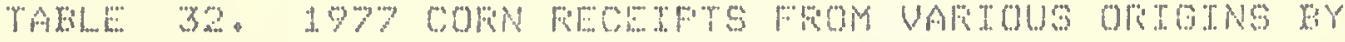
FTFMS TN AFEA GOO Y CONNECTCUT

.

OFTCTNATING

GTAYE OF FOFY AFEA
MOLE OF TRANSFORPATUR

:

FAII...

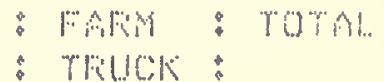

(THOUSANDS OF" BUSHEIS)

1. 1.00 MAFIYLANTI

1850 OHIO

1801 INXIANA

2000 MICHIGAN

7102 CHICAGO AFVEA

TUTAL. VOL...UME

161
2962
1901
1003

$\begin{array}{ll}0 & 0 \\ 0 & 0 \\ 0 & 0 \\ 0 & 0\end{array}$

$\begin{array}{ll}0 & 0 \\ 0 & 0 \\ 0 & 0 \\ 0 & 0\end{array}$

$0 \quad 1.61$

9395

0

0

$73 \%$

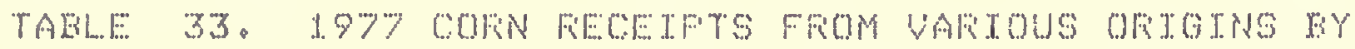
FTFMS IN AREA 1000 y MEILAWARE

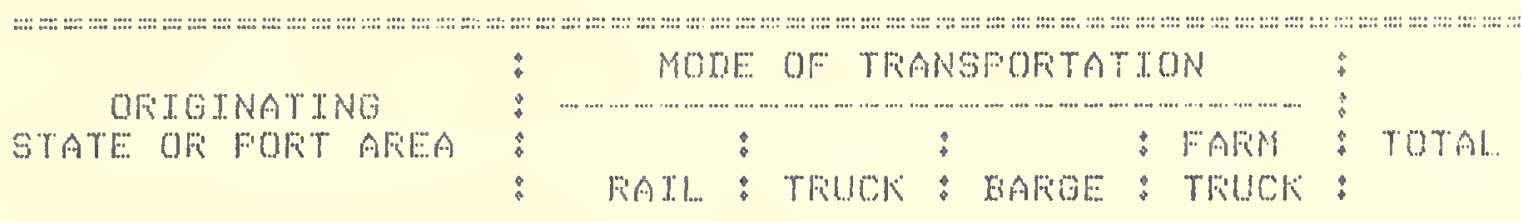

\begin{tabular}{|c|c|c|c|c|c|}
\hline & \multicolumn{4}{|c|}{ (THOUSANRS OF RUSHELS) } & \\
\hline $\begin{array}{l}800 \text { NEW JEFISEY } \\
903 \text { FENNSYI..VANIA A }\end{array}$ & 0 & $\begin{array}{l}250 \\
2100\end{array}$ & 0 & $\begin{array}{l}78 \\
78\end{array}$ & $\begin{array}{l}328 \\
325\end{array}$ \\
\hline 1000 RELAWAFE & 0 & 7448 & 0 & 7190 & 14638 \\
\hline 1100 MAFYLANI & 0 & $657 \%$ & 0 & 2721 & 9296 \\
\hline 1825 ONIO & 0 & 100 & 0 & 0 & 105 \\
\hline TOTAL.. VOLUME & 0 & 1.4628 & 0 & 10064 & 24692 \\
\hline
\end{tabular}

TAKLE 3A. 1977 COFN SHTFMENTS TO VAFTOUS IESTTNATTONS RY FIFIMS IN AFEA 1.000, CUI:LAWAFE:

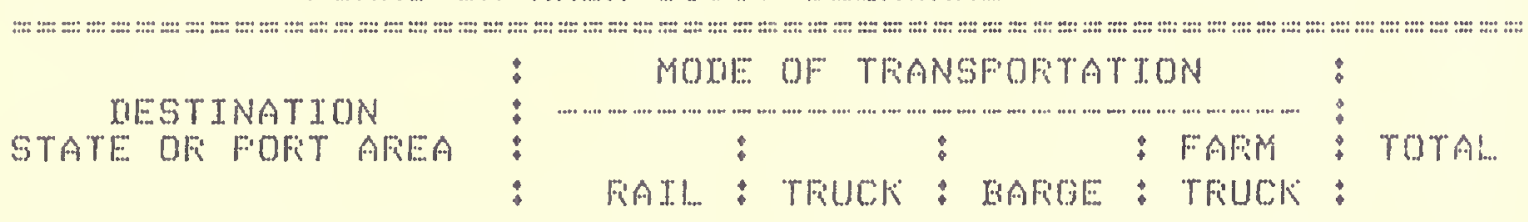

(THOLSANTS OF BUSHELS)

$\begin{array}{llcccc}900 \text { NEW JEFSEY } & 0 & 235 & 0 & 0 & 235 \\ 903 \text { FENNSYLUANTA } & 0 & 500 & 0 & 0 & 500 \\ 1000 \text { MELAWAFE } & 0 & 7448 & 0 & 0 & 7448 \\ 1100 \text { MAFYLANC } & 0 & 4060 & 0 & 0 & 4060 \\ 7202 \text { SOUTH ATLANTIC } & 0 & 90 & 1307 & 0 & 1397 \\ \text { TOTAL VOLUME } & 0 & 12333 & 1307 & 0 & 13640\end{array}$




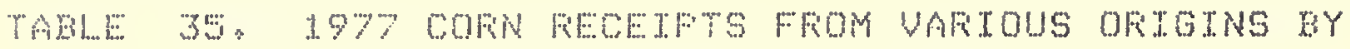
FIFMS IN AFEA 1701 . FLOFITIA

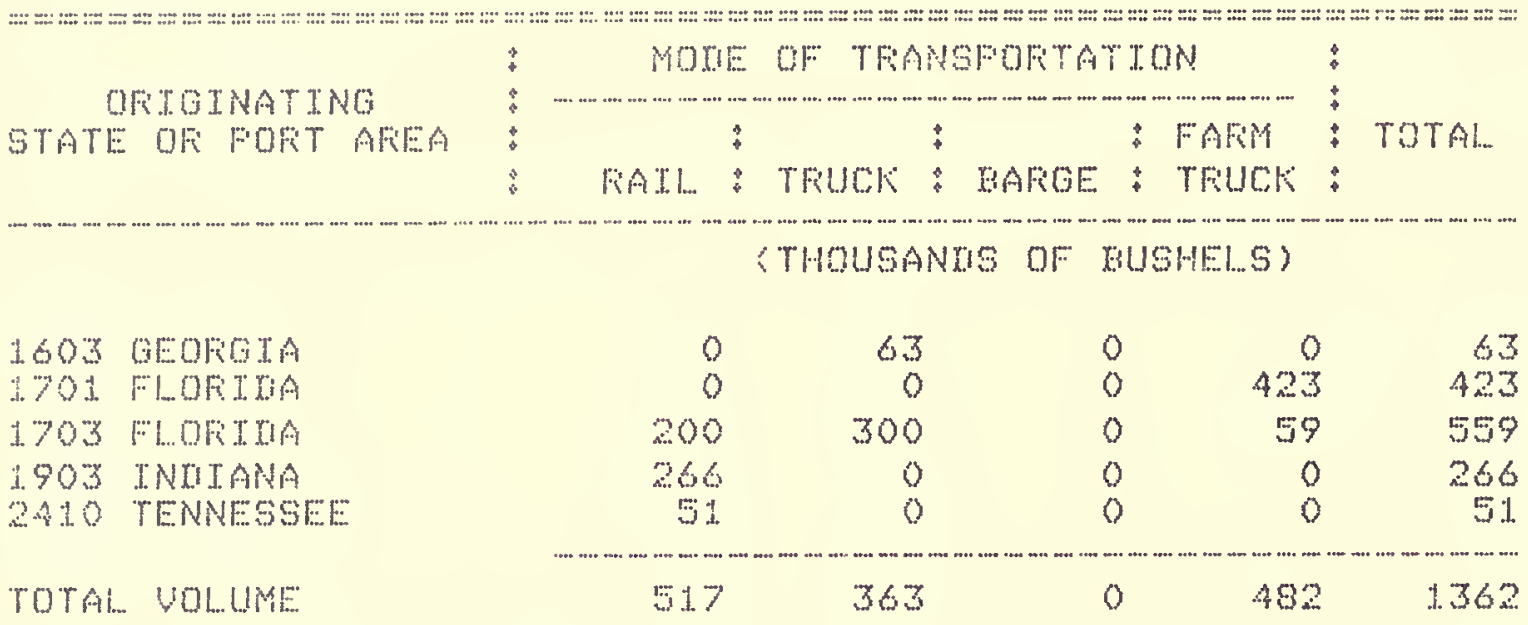

TABHE. 36: 1977 CONN SHTFMENTS TO UAFTOUS DESTINATIONS BY FIFMS IN AREA 1701 * FIOLIMA

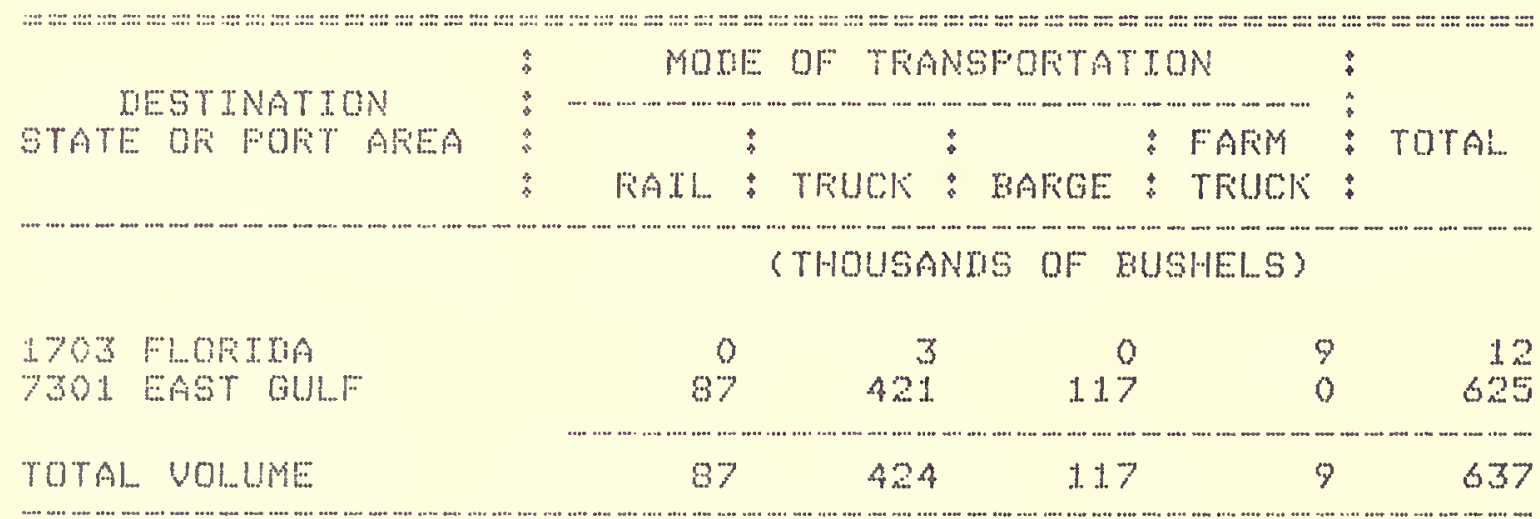


TAELE 37.977 COFEN FECELFTS FFOM UAFIOUS OFITINS EY FIFMS TN AREA 1703 y FIOFITIA

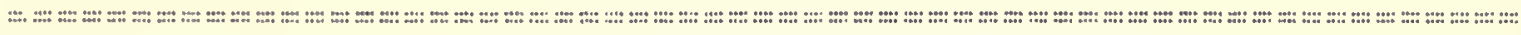

OFIOTNATINE

GTATE OF FORT AFEA
MOLE OF TFANSFOFTATTON

FATI: : TFUCK: : HAFGE: FAFIM: TFUCK:

(THOUSANLS OF" IUSHI:

ISOO SOUTH CAAROL INA

L.603 DEOFGTA

1701 F"LOWIIIA

1703 FILOFI IIA

1705 FI...TIIIA

1901 TNTTANA

1903 INITANA

2268 TLLTNOTS

2ESG ILLTNOTS

2262 ILLINOIS

TOTAL. VOLLUME

540
2059
0

1876

45

1427

1929

21.

100

112

8149

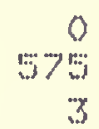

339

1.00

0

0

0

0

0

1017
0

0

0

0

0

0

0

0

0

0

0

0
$5-40$

2634

213

2215

1. 495

1427

1928

2.].

100

152

TAELE 38. 1977 COFN SHIFMENTS TO VAFIOUS IIESTINATIONS BY

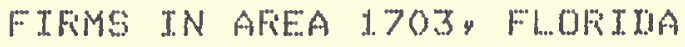

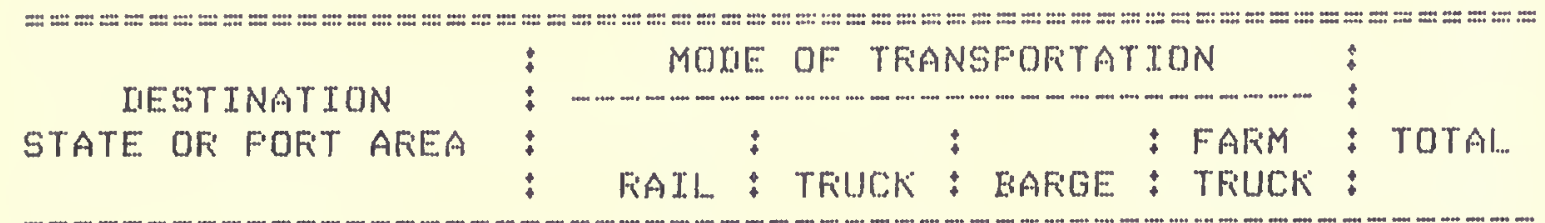

(THOUSANIS OF BUSHELS)

$\begin{array}{lrcrrr}1701 \text { FLOFIIIA } & 200 & 300 & 0 & 0 & 500 \\ 1703 \text { FLOFIIIA } & 1876 & 339 & 0 & 88 & 2303 \\ 1705 \text { FLOFIIIA } & 500 & 263 & 0 & 23 & 786 \\ 7301 \text { EAST GULF } & 564 & 0 & 0 & 0 & 564 \\ \text { TOTAL UOLUME } & 3140 & 902 & 0 & 111 & 4153\end{array}$


TABLE 39. 3977 COFN RECETFYS FFOM UAFTOUS ORTGINS EY FIFMS ITN AFEA 170 Y FI...ORTIIA

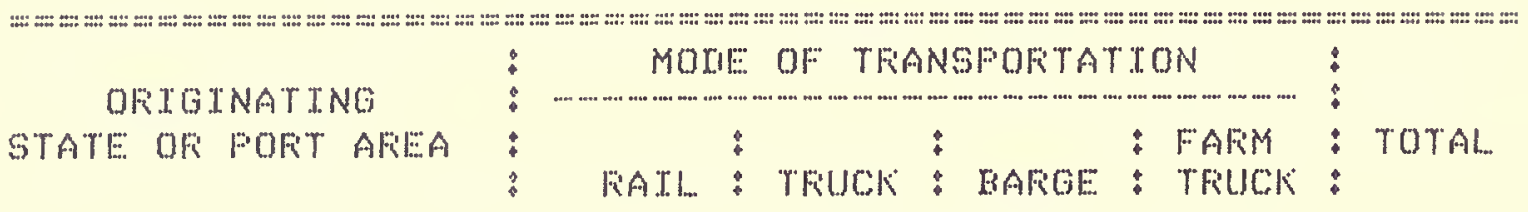

(THOUSANLIS OF BUSHELS)

\begin{tabular}{|c|c|c|c|c|c|}
\hline 1400 NOFTTH CAFOL INA & 709 & 352 & 0 & 0 & 1061 \\
\hline 1603 GEOFOIA & 2187 & 1. $21 \%$ & 0 & 0 & 3404 \\
\hline 1703 FLOFIIA & 500 & 263 & 0 & 1.39 & 902 \\
\hline 1705 FLOFTIIA & 512 & 228 & 0 & $41 \%$ & 1.159 \\
\hline 1902 TNIIANA & 134 & 0 & 0 & 0 & 1.34 \\
\hline INIIANA & 3131 & 0 & 0 & 0 & 3131 \\
\hline TLLI.TNOTS & 500 & 0 & 0 & 0 & 500 \\
\hline IL.L.TNOTS & 0 & 0 & 1.700 & 0 & 1700 \\
\hline KEENTUCKYY & ग. 1.88 & 0 & 0 & 0 & 1. 188 \\
\hline 2607 ALAABMA & 0 & 38 & 0 & 0 & 38 \\
\hline 7302 LOUTSTANA GUI..F & 0 & 0 & 10 & 0 & 50 \\
\hline OTAL VOI..UME & $886 \%$ & 2098 & 1750 & 558 & 13267 \\
\hline
\end{tabular}

TABLE 40.4977 COFN SHIFMENTS TO UARTOUS IIESTINATTONS EY FTRMS IN AFEA J.705, FLOFIDA

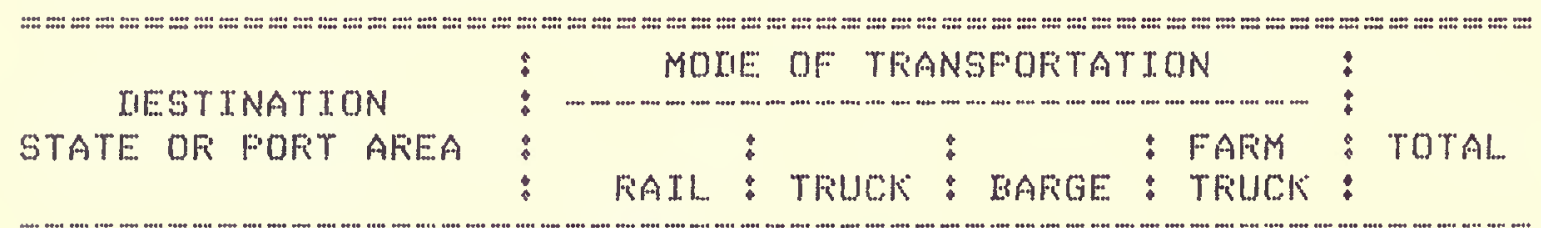

(THOUSANDIS OF RUSHELS)

\begin{tabular}{|c|c|c|c|c|c|}
\hline 1703 FLOFTIIA & 45 & 100 & 0 & 0 & 145 \\
\hline 1705 FLOFIIIA & 12 & 228 & 0 & 0 & 740 \\
\hline 1708 FLOFTIIA & 843 & 971 & 0 & 0 & 1814 \\
\hline OTAL. VOL..U & 1.400 & 1299 & 0 & 0 & 2699 \\
\hline
\end{tabular}


TABLE 41. 1977 COFN FIECEIFTS FFOM UAFIIOUS OFIGINS BY FIFIMS IN AFEA 1708 , FI..OFIIIA

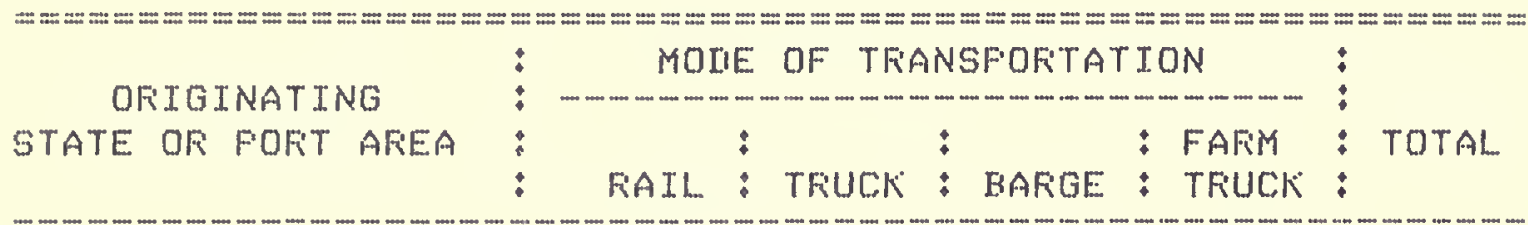

(THOUSANIS OF FUSHELS)

1705 FLOFIXIA

\begin{tabular}{ccccr}
843 & 971 & 0 & 0 & 1814 \\
\hline 843 & 971 & 0 & 0 & 1814
\end{tabular}

TOTAL VOLUME

$-$ 1814

TABLE 42. 1977 COFIN FECEIFTS FFOM UAFIOUS ORIGINS BY FIFMS TN AFEA 1.603, GEOFGIA

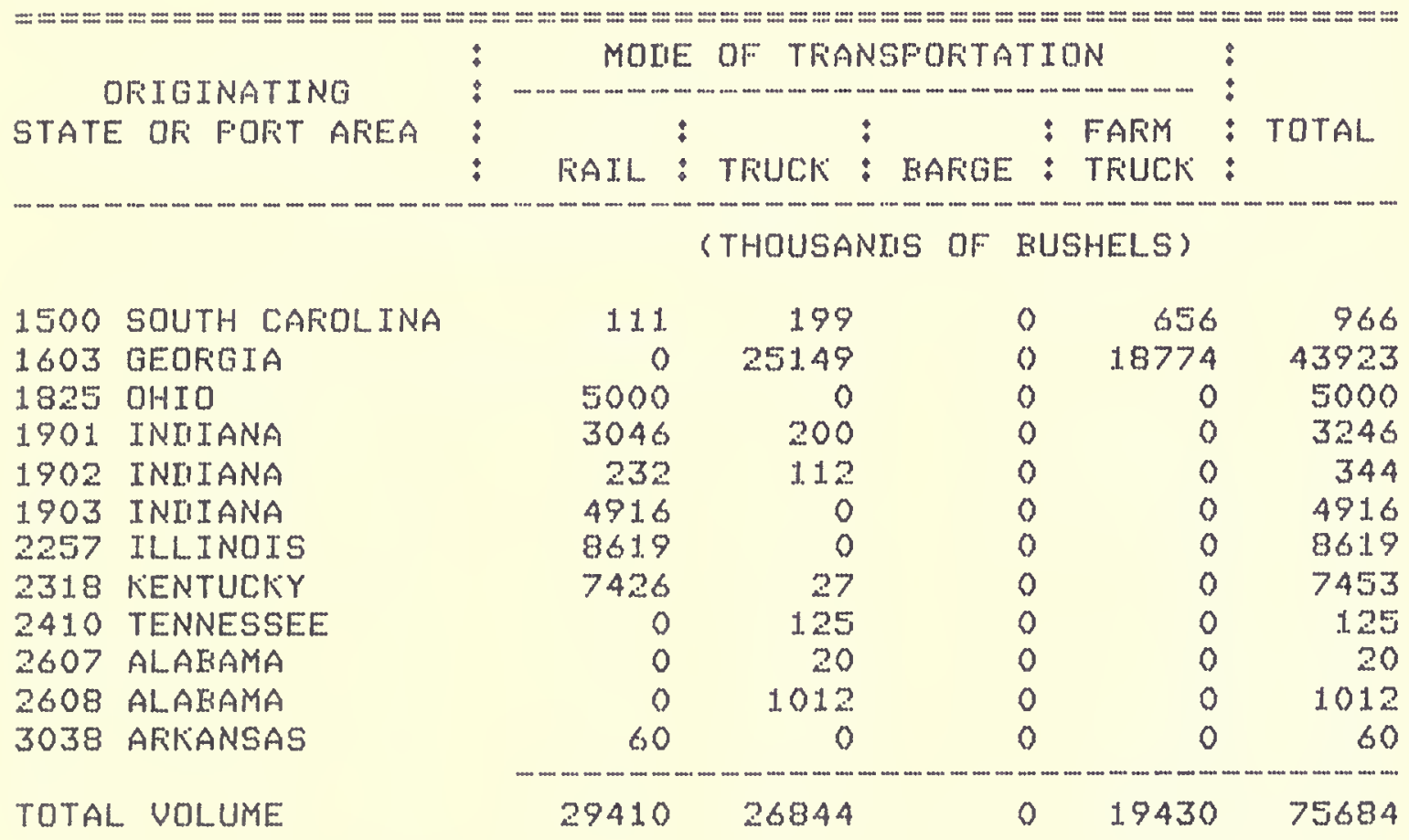


TABLE 43. 1977 COFN SHIFMENTS TO VAFIOUS IESTINATIONS EY FIFMS IN AFEEA 1603 , GEOFGIA

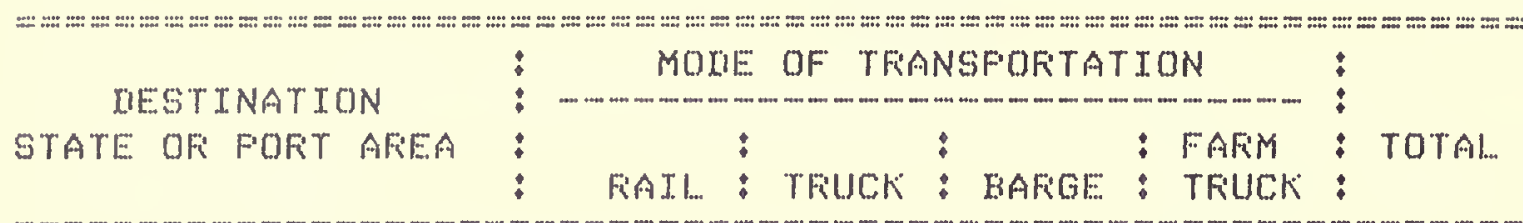

(THOUSANUS OF EUSHELIS)

$\begin{array}{llrrrrr}1500 & \text { SOUTH CAFOLINA } & 476 & 0 & 0 & 0 & 476 \\ 1.603 & \text { GEOFGIA } & 0 & 251.49 & 0 & 9452 & 34601 \\ 1609 \text { GEOFGIA } & 334 & 345 & 0 & 0 & 679 \\ 1701 \text { FLOFIIA } & 0 & 63 & 0 & 0 & 63 \\ 1703 \text { FLOFIDA } & 2059 & 575 & 0 & 0 & 2634 \\ 1705 \text { FLOFIIA } & 2187 & 1217 & 0 & 0 & 3404 \\ 2412 & \text { TENNESSEE } & 0 & 141 & 0 & 0 & 141 \\ 2503 \text { MISSISSIFI } & 378 & 394 & 1363 & 0 & 0 & 1657 \\ 2607 \text { ALABAMA } & 176 & 0 & 0 & 0 & 176 \\ 3100 \text { LOUISIANA } & 0 & 215 & 0 & 0 & 215 \\ 7202 \text { SOUTH ATLANTIC } & 5904 & 29071 & 0 & 9452 & 44427\end{array}$

TABI..E 44. 1977 CORN FECEIFTS FFOM UAFIOUS OFIGINS BY FIFIMS TN AFEA 1609, CEFORGTA

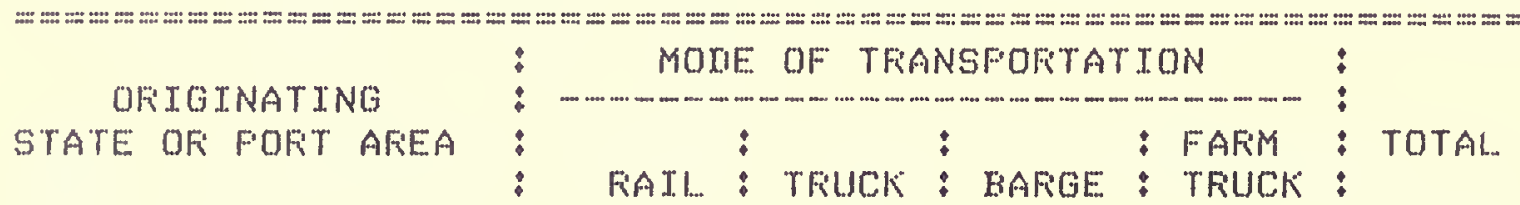

\begin{tabular}{|c|c|c|c|c|c|c|}
\hline \multirow{2}{*}{\multicolumn{2}{|c|}{1400 NOFITH CAFOLINA }} & \multicolumn{3}{|c|}{ (THOUSANDS OF } & EUSSHELS) & \multirow[b]{2}{*}{184} \\
\hline & & 0 & 194 & 0 & 0 & \\
\hline 1603 & GEOFGIA & 334 & 345 & 0 & 345 & 1024 \\
\hline 1609 & GEOFGIA & 241 & 75 & 0 & 0 & 316 \\
\hline 1901 & INIIANA & 693 & 0 & 0 & 0 & 693 \\
\hline 1902 & INIIANA & 5853 & 0 & 0 & 0 & 5853 \\
\hline 1903 & INIIANA & 1.5832 & 0 & 0 & 0 & 15832 \\
\hline 2257 & ILLINOTS & 12477 & 0 & 0 & 0 & 12477 \\
\hline 2258 & ILLINOTS & 43 & 0 & 0 & 0 & 43 \\
\hline 2259 & TLLTNOIS & 881 & 0 & 0 & 0 & 881 \\
\hline 2262 & ILLINOTS & 466 & 58 & 0 & 0 & 524 \\
\hline 2270 & ILLINOIS & 5000 & 0 & 0 & 0 & 5000 \\
\hline 2319 & KEENTUCK゙Y & 374 & 0 & 0 & 0 & 374 \\
\hline 2410 & TENNESSEE & 0 & 0 & 0 & 150 & 150 \\
\hline 2411 & TENNESSEE & 210 & 96 & 0 & 0 & 306 \\
\hline 2412 & TENNESSEE & 990 & 0 & 0 & 0 & 990 \\
\hline 2803 & IOWA & 815 & 0 & 0 & 0 & 815 \\
\hline TOTA & VOLUME & 44208 & 768 & 0 & 495 & 45472 \\
\hline
\end{tabular}


TAELE 45. 1977 COFN SHIFMENTS TO UAFIIOUS IESTINATIONS BY FIFIMS IN AREA 1609, CEOFGIA

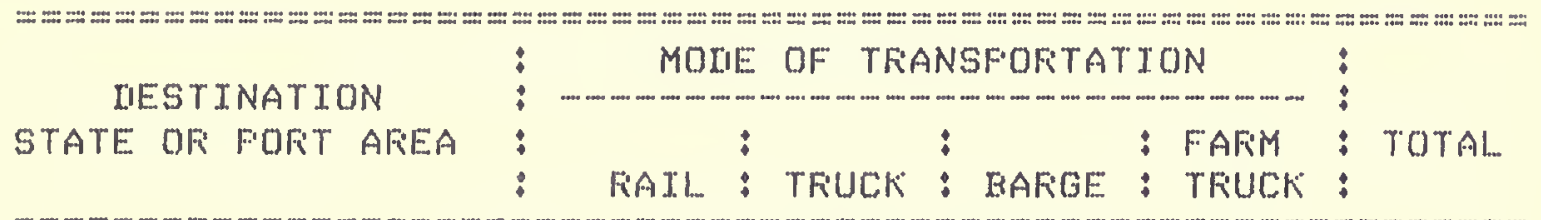

$\begin{array}{lcccrr} & & & \\ 1609 \text { GEOFGIA } & 241 & 75 & 0 & 1758 & 2074 \\ 2608 \text { ALABAMA } & 145 & 1.33 & 0 & 0 & 278 \\ \text { TOTAL VOLUME } & 386 & 208 & 0 & 1758 & 2352\end{array}$

TAELE 46. 1977 COFN FECEIFTS FFOM UAFIOUS OFIGINS BY FIFIS IN AFEA 22E6 Y ILLINOIS

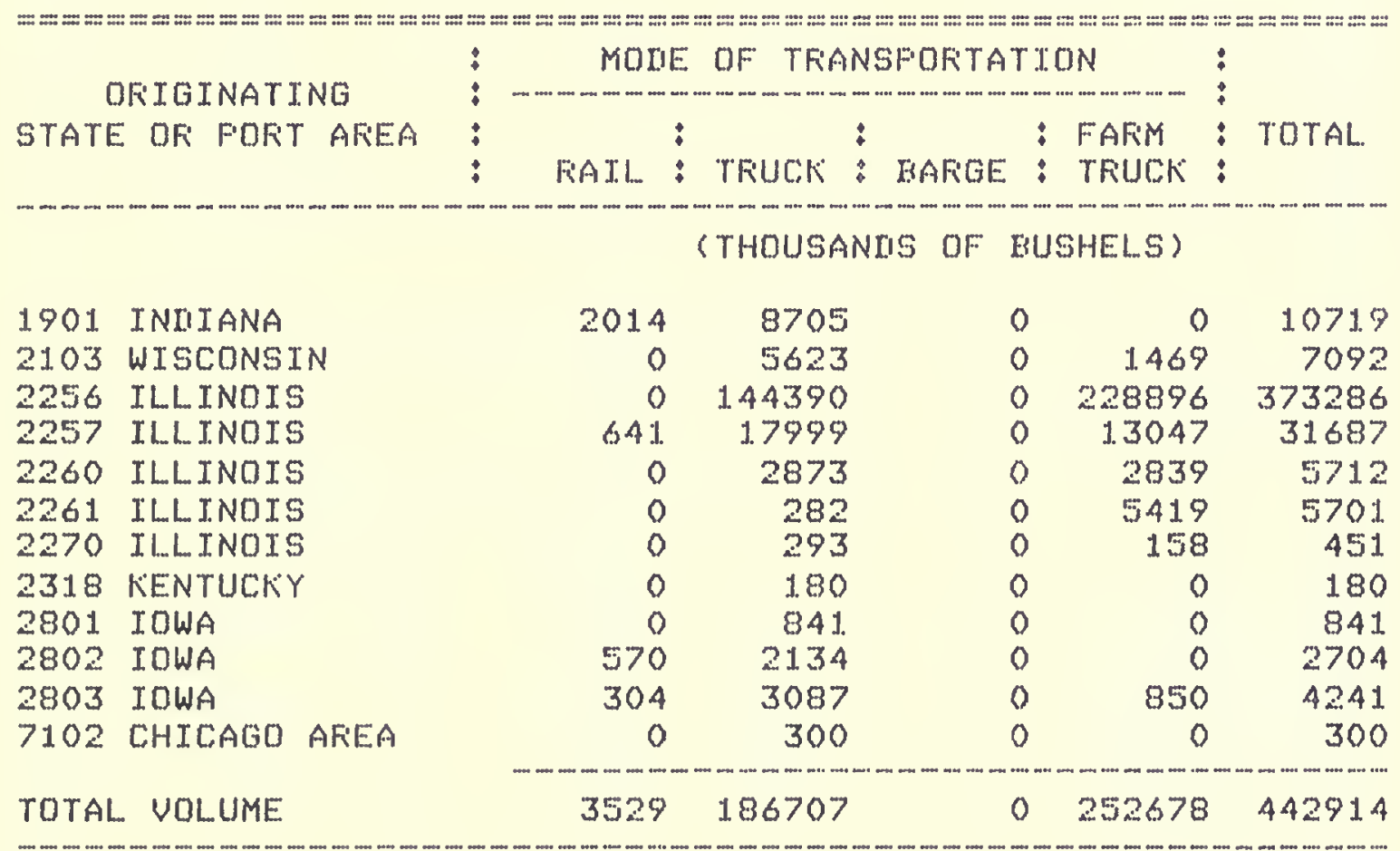


TARLE 47. 1977 CORN SHIFMENTS TO VAFIOUS DESTINATIONS EY FIFMS IN AFEA 2256, ILLINOIS

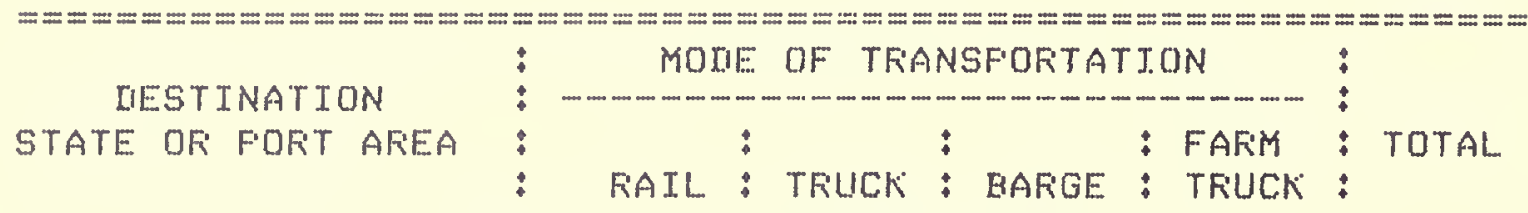

(THOUSANIIS OF EUSHELS)

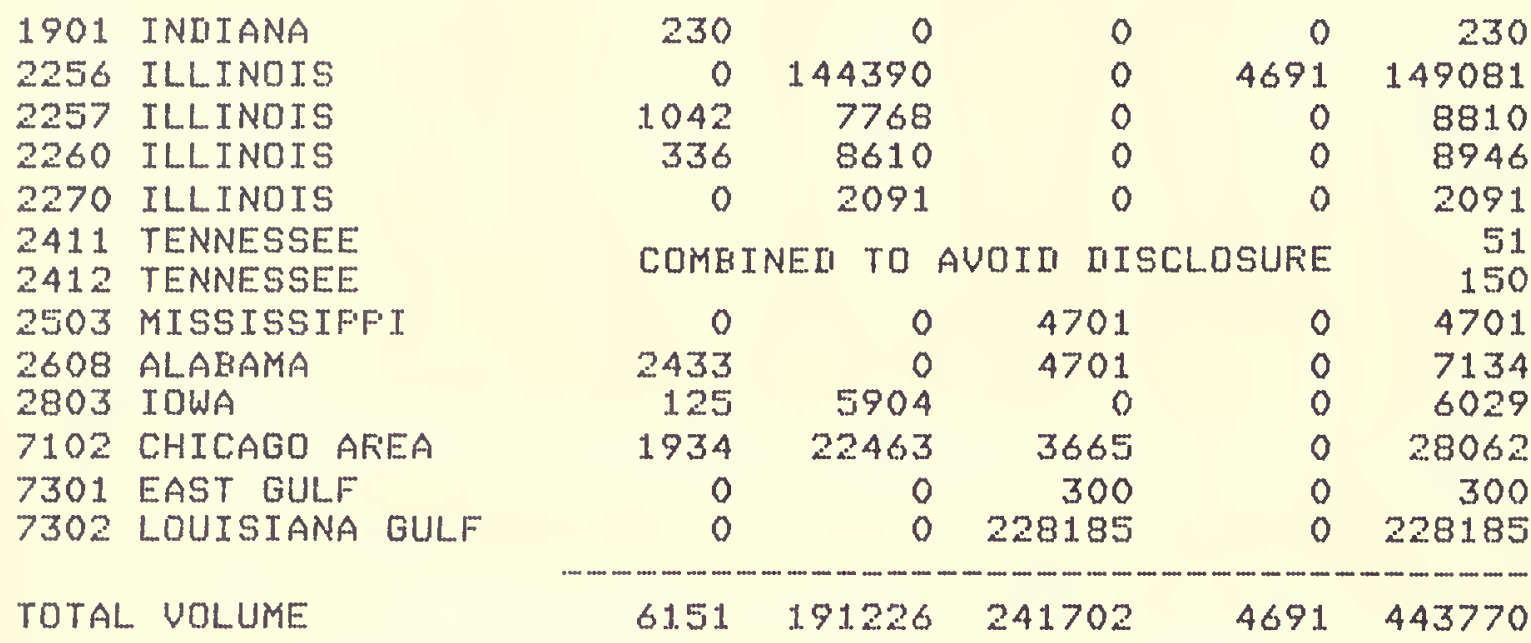

TAELE 48. 1977 COFN FECEIFTS FFOM UAFIOUS OFIGINS EY FIFMS IN AFEA 2257, ILLINOIS

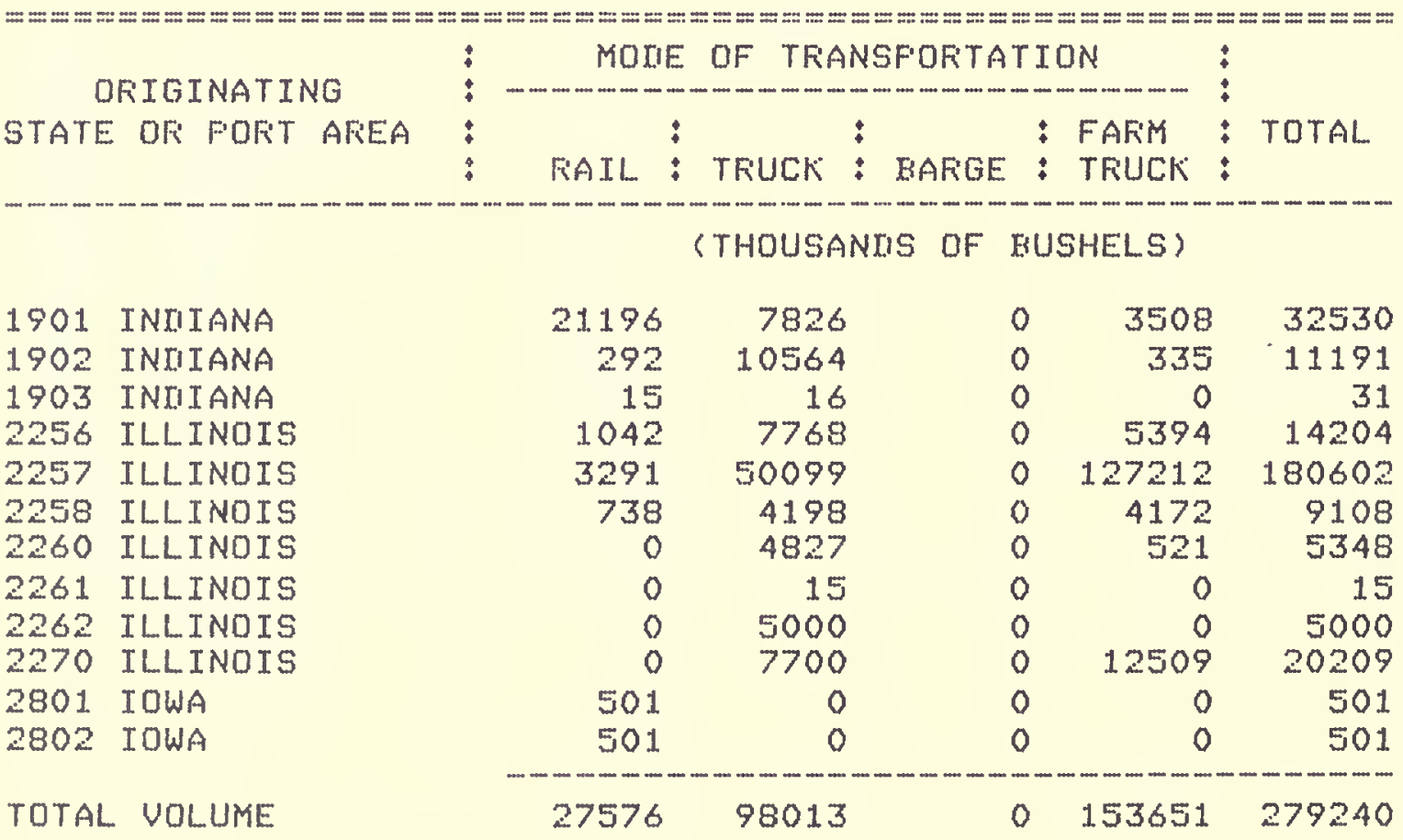


TABLE 49. 1977 COFN SHIFMENTS TO UAFIOUS IIESTINATIONS BY FIFMS IN AFEA 2257, TLLINOIS

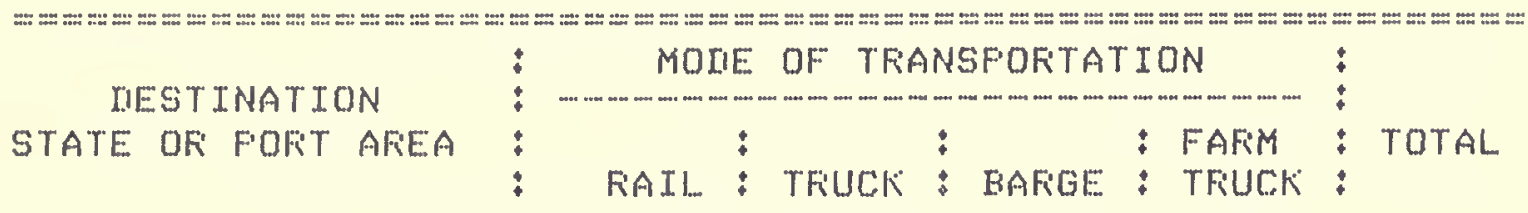

\section{(THOUSANIS OF BUSHELS)}

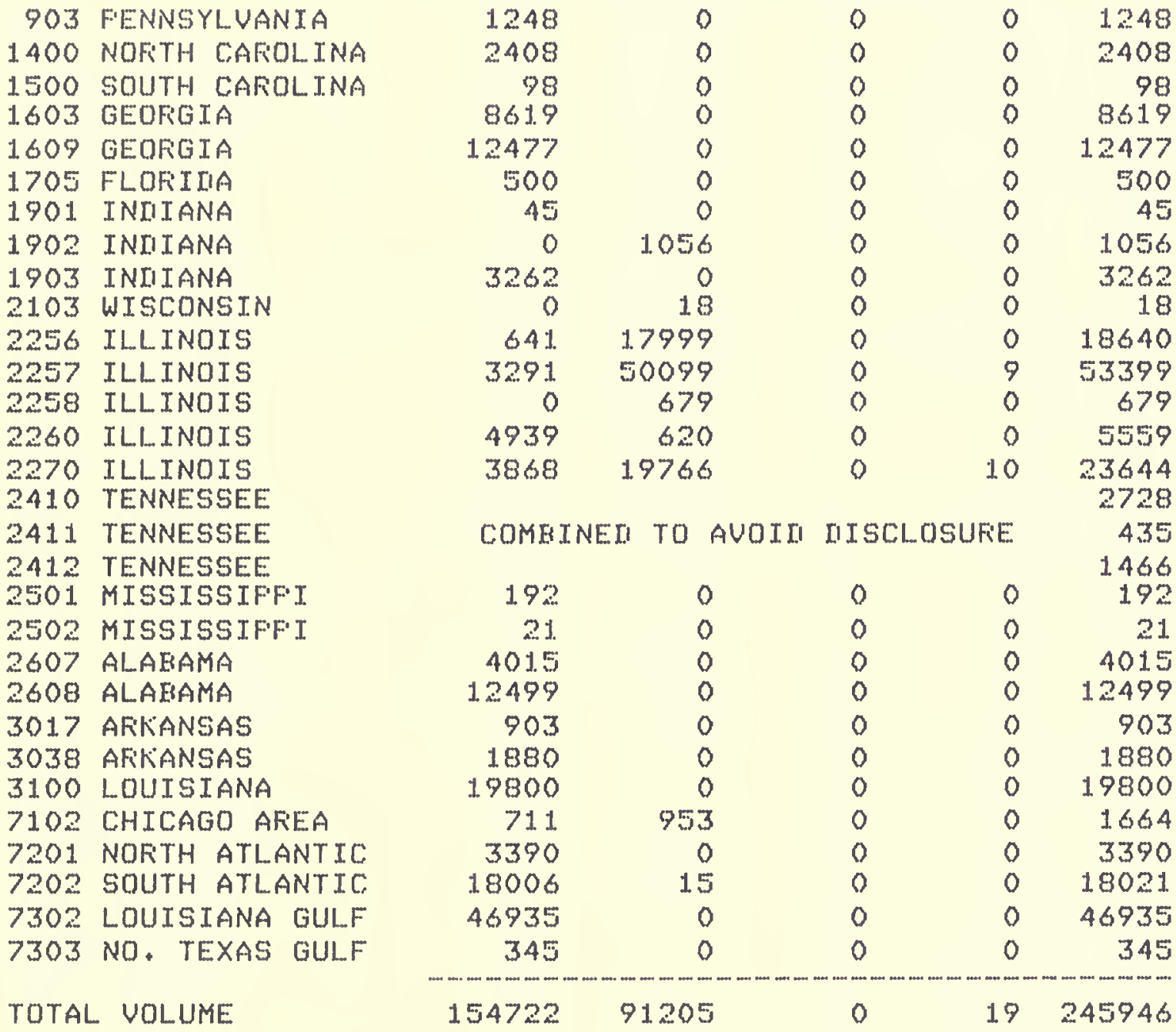


TABLE 50. 1977 COFN FECFTFTS FROM UAFIOUS OFIGINS BY FIFUS IN AFEEA 2258 Y ILLINOIS

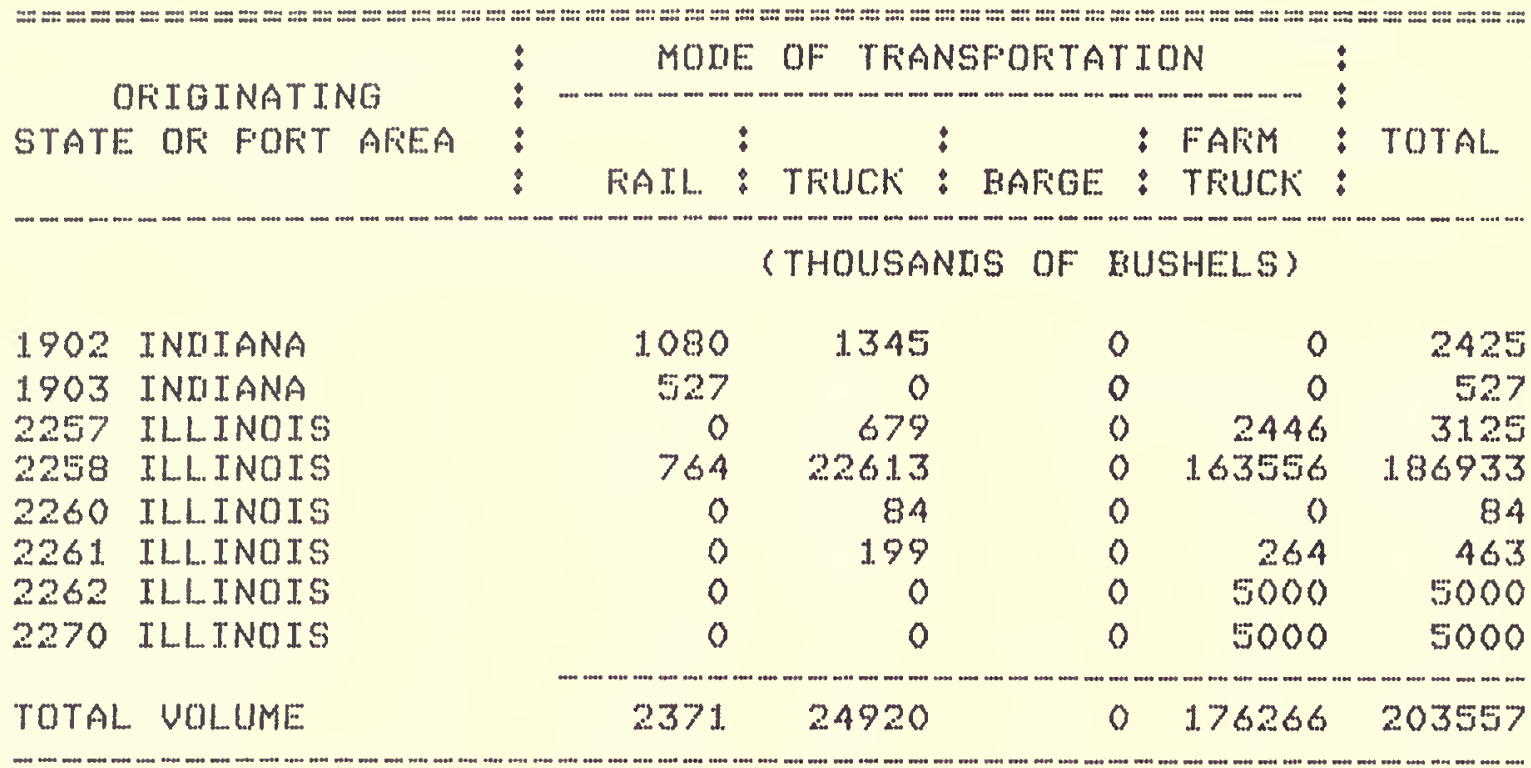


TABLE 51. 1977 COFN SHIFMENTS TO VARIOUS IIESTINATIONS BY FIFMS IN AREA 2258, ILLINOIS

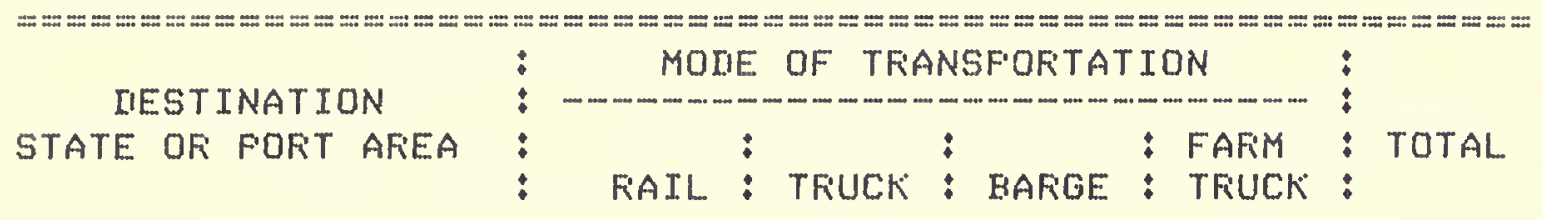

(THOUSANIIS OF EUSHELS)

\begin{tabular}{|c|c|c|c|c|c|c|}
\hline 901 & FENNSYLUANIA & 0 & 864 & 0 & 0 & 864 \\
\hline 903 & FENNSYLUANIA & 0 & 414 & 0 & 0 & 414 \\
\hline 1100 & MAFIYLAND & 0 & 183 & 0 & 0 & 183 \\
\hline 1400 & NOFTH CAFOLINA & 0 & 183 & 0 & 0 & 183 \\
\hline 1609 & GEOFIGIA & 43 & 0 & 0 & 0 & 43 \\
\hline 1703 & FLOFIIIA & 21 & 0 & 0 & 0 & 21 \\
\hline 1825 & OHIO & 0 & 183 & 0 & 0 & $1 . \overline{8}$ \\
\hline 1903 & INIIANA & 22 & 1.880 & 0 & 0 & 1.902 \\
\hline 2256 & ILL INOIS & $\begin{array}{r}0 \\
770\end{array}$ & $\begin{array}{r}0 \\
1+00\end{array}$ & 0 & 35 & $10 \times 6$ \\
\hline 2257 & ILLINOIS & 738 & 4198 & 0 & 0 & 4936 \\
\hline 2258 & ILLINOIS & 764 & 22613 & 0 & 5413 & 28790 \\
\hline 2259 & ILLINOIS & 0 & 11805 & 0 & 0 & 11805 \\
\hline 2260 & ILLINOIS & 1572 & 18853 & 0 & 0 & 20425 \\
\hline 2261 & ILLINOIS & 0 & 359 & 0 & 0 & 359 \\
\hline 2262 & ILLINOIS & 517 & 7813 & 0 & 0 & 8330 \\
\hline 2270 & ILLINOIS & 15079 & 17200 & 0 & 0 & 32279 \\
\hline 2318 & KEENTUCKYY & 181 & 0 & 0 & 0 & 181 \\
\hline 2319 & KEENTUCKYY & 1.024 & 0 & 0 & 0 & 1024 \\
\hline 2411 & TENNESSEE & 89 & 4563 & 0 & 0 & 4652 \\
\hline 2412 & TENNESSEE & 0 & 1.521 & 0 & 0 & 1521 \\
\hline $\begin{array}{l}2501 \\
2502\end{array}$ & $\begin{array}{l}\text { MISSISSIFFI } \\
\text { MISSISSIFFI }\end{array}$ & $\begin{array}{r}0 \\
576\end{array}$ & $\begin{array}{r}54 \\
189\end{array}$ & $\begin{array}{l}0 \\
0\end{array}$ & $\begin{array}{l}0 \\
0\end{array}$ & $\begin{array}{r}54 \\
765\end{array}$ \\
\hline 2503 & MISSISSIFFI & 51.60 & 2787 & 0 & 0 & 7947 \\
\hline 2608 & ALABAMA & 234 & 0 & 0 & 0 & 234 \\
\hline 2903 & MISSOUFI & 352 & 6320 & 0 & 0 & 6672 \\
\hline 3005 & AFKKANSAS & 342 & 0 & 0 & 0 & 342 \\
\hline 3016 & ARKIANSAS & 0 & 183 & 0 & 0 & 183 \\
\hline 3017 & AFIKIANSAS & 0 & 324 & 0 & 0 & 324 \\
\hline 3038 & AFIKANSAS & 3316 & 0 & 0 & 0 & 3316 \\
\hline 3100 & LOUISIANA & 228 & 0 & 0 & 0 & 228 \\
\hline 3503 & K゙ANSAS & 0 & 183 & 0 & 0 & 183 \\
\hline 3745 & TEXAS & 497 & 791 & 0 & 0 & 1288 \\
\hline 3789 & TEXAS & 24 & 0 & 0 & 0 & 24 \\
\hline 7102 & CHICAGO AFEA & 0 & 252 & 0 & 0 & 252 \\
\hline 7201 & NOFTH ATLANTIC & 1865 & 0 & 0 & 0 & 1865 \\
\hline 7202 & SOUTH ATLANTIC & 12544 & 0 & 0 & 0 & 12544 \\
\hline 7301 & EAST GULF & 7650 & 0 & 0 & 0 & 7650 \\
\hline 7302 & LOUISIANA GULF & 23867 & 0 & 0 & 0 & 23867 \\
\hline 9000 & EXFOFIT & 0 & 1278 & 0 & 0 & 1278 \\
\hline TOTAL & VOLUME & 76705 & 104993 & 0 & 5448 & 187146 \\
\hline
\end{tabular}


TAELE 52. 1.977 CORN FIECEIFTS FFOM UAFIOUS OFIGINS EY FIRMS IN AREA 22S9, ILIINOIS

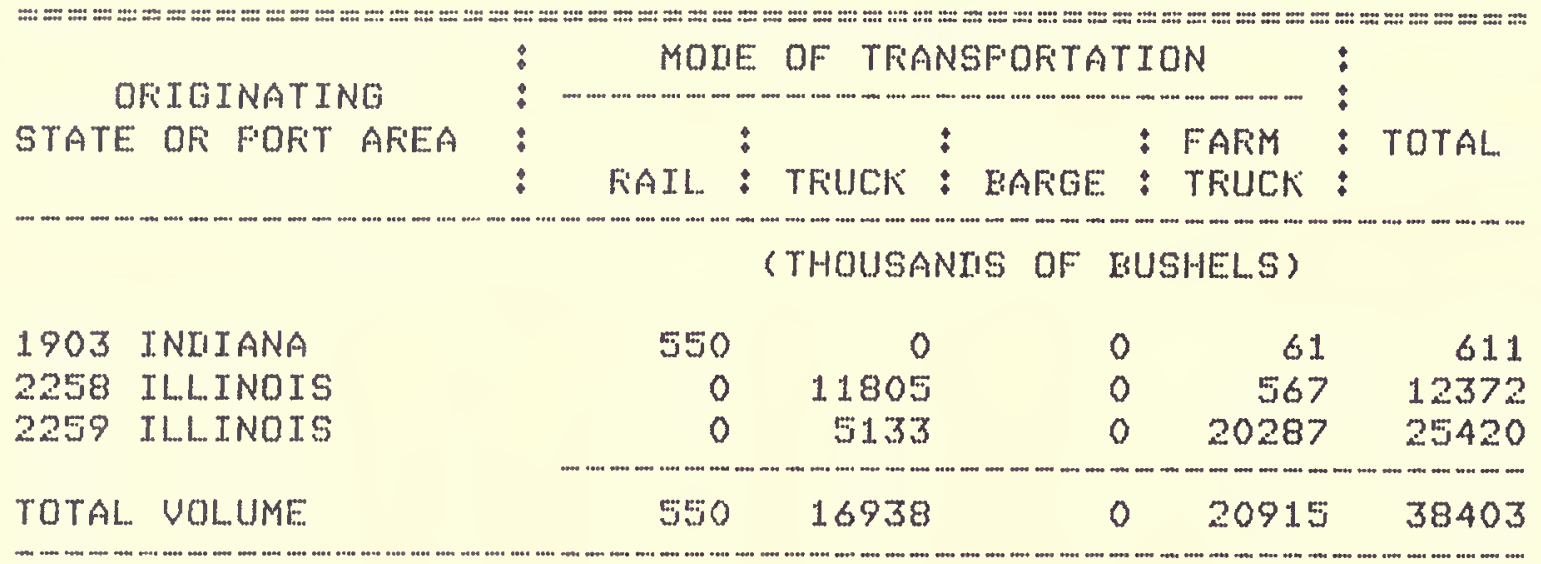

TABLE 53.1977 CORN SHIFMENTS TO UAFIDUS DESTINATIONG EY FIFIMS IN AFIEA 2259, ILLINOIS

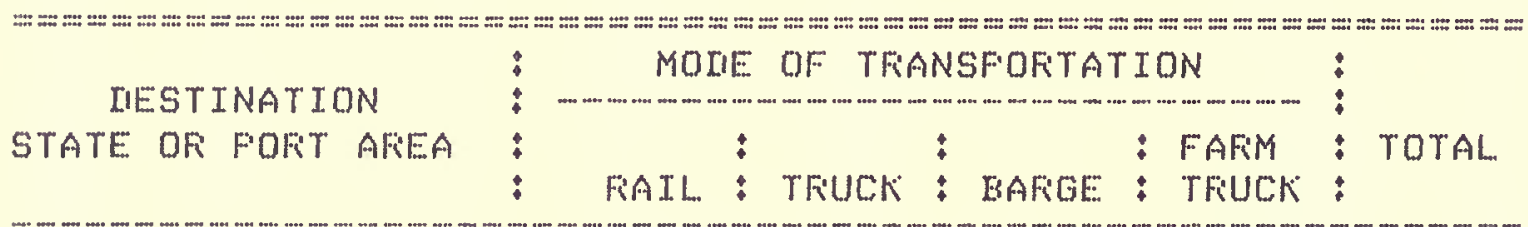

(THOUSANIS OF BUSHELS)

\begin{tabular}{|c|c|c|c|c|c|c|}
\hline 1609 & GEOFGIA & 881. & 0 & 0 & 0 & 881 \\
\hline 1703 & FLOFIIIIA & 100 & 0 & 0 & 0 & 100 \\
\hline 1903 & INUIANA & 0 & 4551 & 0 & 0 & 4551 \\
\hline 2259 & ILLINOIS & 0 & 5133 & 0 & 0 & 5133 \\
\hline 2411 & TENNESSEE & 61 & 0 & 0 & 0 & 61 \\
\hline 2503 & MISSISSIFFI. & 7479 & 0 & 0 & 0 & 7479 \\
\hline 2607 & AL..ABAMA & 0 & 395 & 0 & 0 & 395 \\
\hline 2608 & ALAEAMA & $11.6 \%$ & 3220 & 2000 & 0 & 6381 \\
\hline 7302 & LOUISIANA GULF & 0 & 0 & 7391 & 0 & 7391 \\
\hline OTAL & VOL & 9682 & 13299 & 9391 & 0 & 3237 \\
\hline
\end{tabular}

TQTAL UOLUME


TABLE 54. 1977 COFN FECEIFTS FFOM UAFIOUS OFIGINS BY FIFIS IN AFEA 2260, ILLINOIS

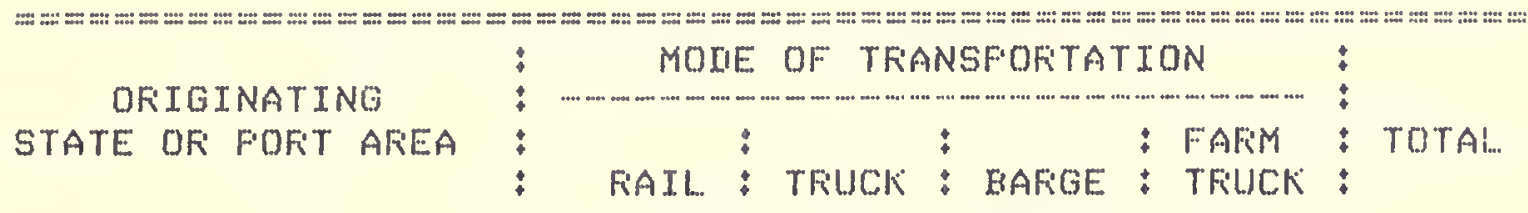

(THOUSANAS OF RUSHELS)

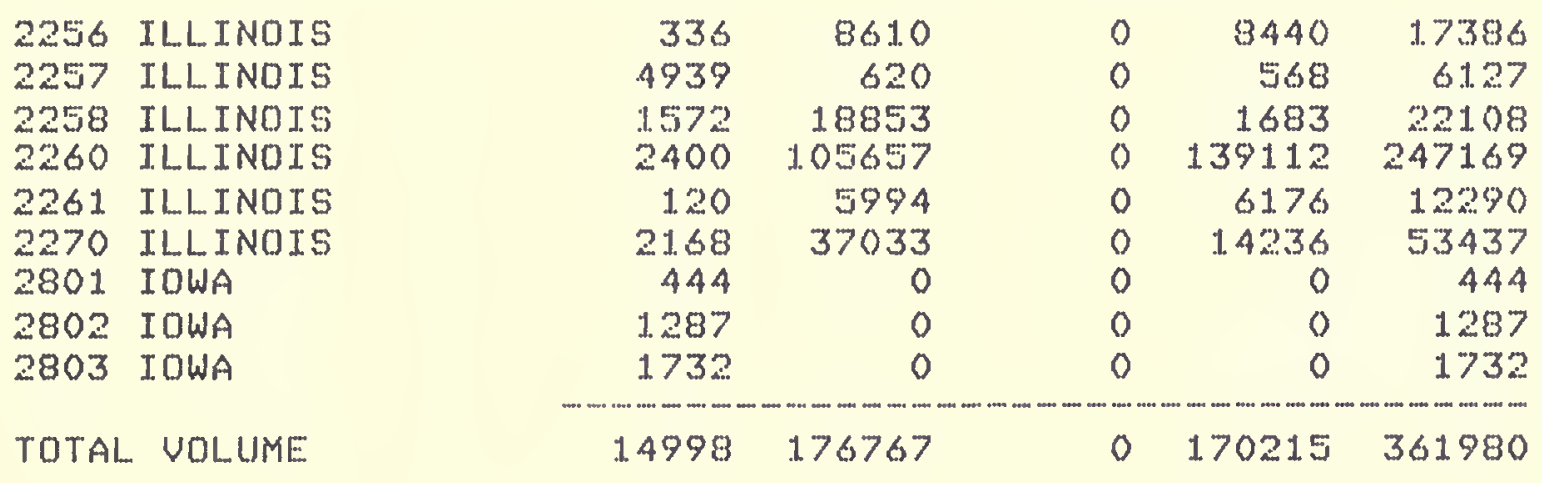

TAELE 55, 1977 COFN SHIFMENTS TO VAFIOUS DESTINATIONS EY FIFMS IN AFEA 2260, ILLINOIS

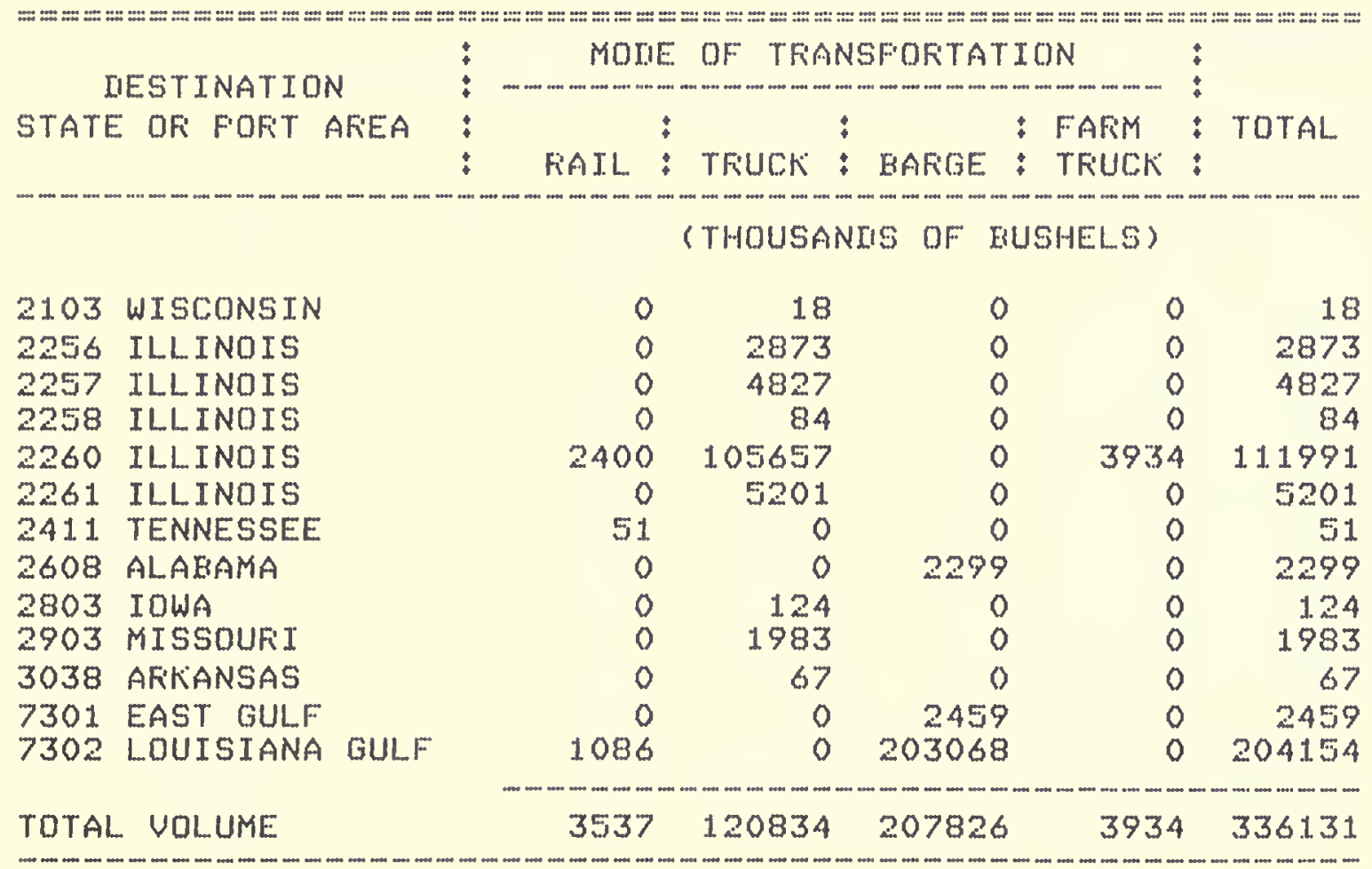


TABLE 56. 1977 COFN FECEIFTS FFOM UAFIOUS OFIGINS BY FIFMS IN AFEA 2261, ILLINOIS

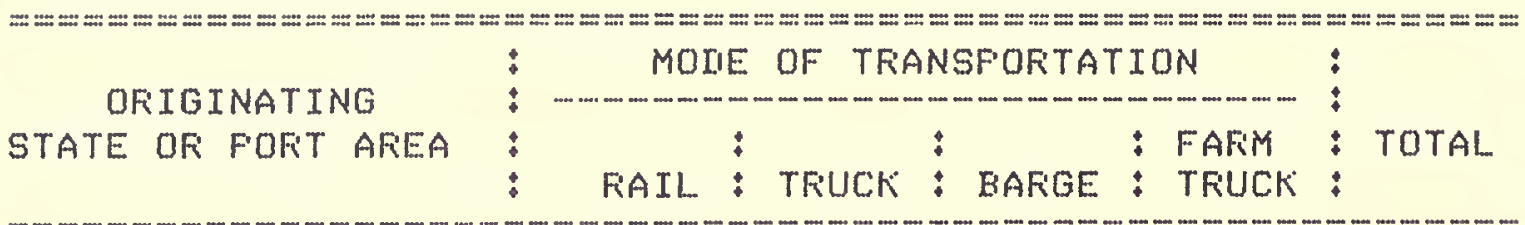

(THOUSANIS OF BUSHELS)

\begin{tabular}{|c|c|c|c|c|c|c|}
\hline 2258 & ILLINOIS & 0 & 359 & 0 & 536 & 895 \\
\hline 2260 & J.LLINOIS & 0 & 5201 & 0 & 4086 & 9287 \\
\hline 2261 & ILLINOIS & 0 & 17975 & 0 & 42259 & 60234 \\
\hline 2262 & ILLINOIS & 0 & 0 & 0 & 525 & 525 \\
\hline 2802 & IOWA & 0 & 202 & 0 & 0 & 202 \\
\hline 2803 & IOWA & 0 & 8399 & 0 & 40 & 8439 \\
\hline 2901 & MISSOUFII & 0 & 1810 & 0 & 1656 & 3566 \\
\hline 2902 & MISSOURI & 0 & 1002 & 0 & 730 & 1732 \\
\hline 2903 & MISSOUFI & 0 & 0 & 0 & 298 & 298 \\
\hline TOTAL & VOL.UME & 0 & 35048 & 0 & 50130 & 85178 \\
\hline
\end{tabular}

TABLE 57. 1977 COFN SHIFMENTS TO VAFIOUS IIESTINATIONS EY FIFMS IN AREA 2261 y ILLINOJS

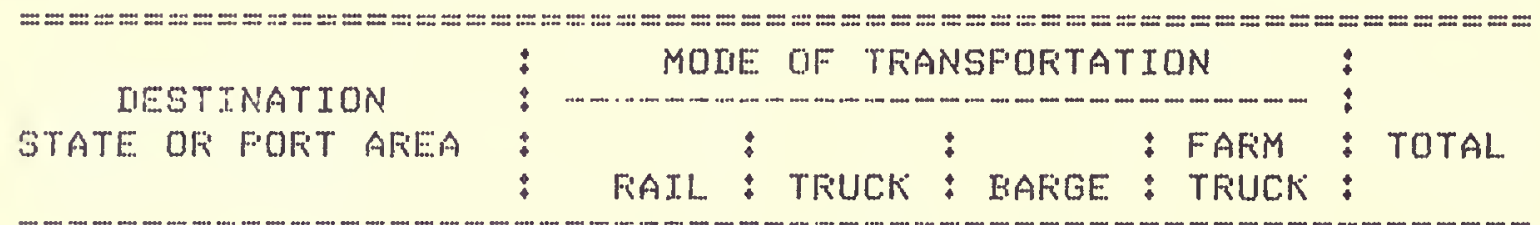

(THOUSANISS OF BUSHELS)

\begin{tabular}{|c|c|c|c|c|c|c|c|}
\hline 1705 & FLOFITIIA & & 0 & 0 & 1700 & 0 & 1700 \\
\hline 2256 & ILLINOIS & & 0 & 282 & 0 & 0 & 282 \\
\hline 2257 & ILLINOIS & & 0 & 15 & 0 & 0 & 15 \\
\hline 2258 & ILLINOIS & & 0 & 199 & 0 & 0 & 199 \\
\hline 2260 & ILLINOTS & & 120 & 5994 & 0 & 0 & 6114 \\
\hline 2261 & TLLINOIS & & 0 & 17975 & 0 & 5036 & 23011 \\
\hline 2262 & ILLINOIS & & 105 & 1605 & 0 & 0 & 1710 \\
\hline 2608 & ALABAMA & & 0 & 0 & 3162 & 0 & 3162 \\
\hline 2803 & TOWA & & 0 & 58 & 0 & 0 & 58 \\
\hline 7302 & LOUISIANA & GULF & 0 & 0 & 41624 & 0 & 41624 \\
\hline TOTAL & VOLUME & & 225 & 26128 & 46486 & 5036 & 77875 \\
\hline
\end{tabular}


TAILE 58. 1977 COFN FECEIFTS FHOM UAFIOUS OFIGINS BY FIFIMS IN AREA 2262 y ILLINOIS

\begin{tabular}{|c|c|c|c|c|c|c|c|}
\hline OFIGTNATTNE & $\vdots \vdots$ & \multicolumn{5}{|c|}{ MOIIE OF TFANSFOFTATION } & \multirow{3}{*}{ TOTAL. } \\
\hline STATE OF FOFT AFEA & : & & : & $:$ & : & FAFiM & \\
\hline & ! & FIATL & : TFUUCK & : RAFIGE & $:$ & TFIUCKK & \\
\hline & & \multicolumn{5}{|c|}{ (THOUSANDS DF EUSHELS) } & \\
\hline 2258 TLLINOIS & & 517 & 7813 & & 0 & 897 & 9227 \\
\hline 2259 IL.... TNOIS & & 0 & 0 & 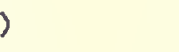 & 0 & 7892 & 7892 \\
\hline 2261 ILLINOIS & & 105 & 1605 & & () & 61 & 1771 \\
\hline 2262 ILLINOTS & & 69 & 1.907 & & 0 & 18499 & 20475 \\
\hline 2300 KENTUCKY & & 0 & 0 & & 0 & 1.07 & 107 \\
\hline 2802 IOWA & & 61. & 0 & & 0 & 0 & 61 \\
\hline 2901 MISSOUFI & & 0 & 211 & & 0 & 0 & 211 \\
\hline 2902 MISSOUFI. & & 0 & 0 & & 0 & 388 & 388 \\
\hline 2903 MISSOUFI & & 0 & 0 & & 0 & 40 & 40 \\
\hline ITAL VOLUME & & 752 & $11: 36$ & & 0 & 27884 & 40172 \\
\hline
\end{tabular}

TABLE 59.1977 COFN SHIFMENTS TO UAFIOUS IIESTINATIONS BY FTEMS IN AFEA 2262 YLLINOIS

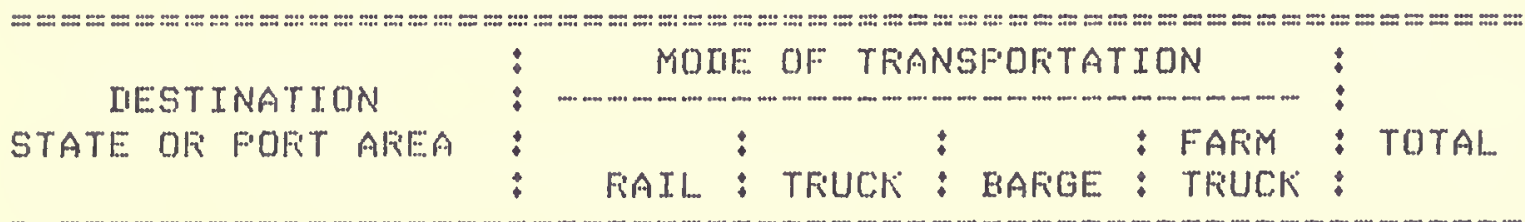

\begin{tabular}{|c|c|c|c|c|c|c|}
\hline \multirow[b]{2}{*}{1609} & \multirow[b]{2}{*}{ GEOFIGIA } & \multicolumn{4}{|c|}{ (THOUSANIS OF BUSHELS) } & \multirow[b]{2}{*}{524} \\
\hline & & 466 & 58 & 0 & 0 & \\
\hline 1703 & FLOFIIIA & 152 & 0 & 0 & 0 & 152 \\
\hline 2257 & ILLINOTSS & 0 & 5000 & 0 & 0 & 5000 \\
\hline 2259 & ILLINOIS & 0 & 0 & 0 & 1200 & 1200 \\
\hline 2262 & ILLINOIS & 69 & 1907 & 0 & 116 & 2092 \\
\hline 2411 & TENNESSEE & 129 & 0 & 0 & 0 & 129 \\
\hline 2412 & TENNESSEE & 3986 & 0 & 0 & 0 & 3986 \\
\hline 2502 & MISSISSIFFI & 650 & 0 & 0 & 0 & 650 \\
\hline $\begin{array}{l}2503 \\
2608\end{array}$ & $\begin{array}{l}\text { MISSISSIFFI } \\
\text { ALAEAMA }\end{array}$ & $\begin{array}{r}8006 \\
836\end{array}$ & $\begin{array}{l}0 \\
0\end{array}$ & $\begin{array}{l}0 \\
0\end{array}$ & $\begin{array}{l}0 \\
0\end{array}$ & $\begin{array}{r}8006 \\
836\end{array}$ \\
\hline 2903 & MISSOUFII. & 175 & 1.12 & 0 & 0 & 287 \\
\hline 3038 & AFiKEANSAS & 0 & 270 & 0 & 0 & 270 \\
\hline 3100 & LOUISIANA & 356 & 0 & 0 & 0 & 356 \\
\hline 3745 & TEXAS & 196 & 0 & 0 & 0 & 196 \\
\hline 7302 & LOUISIANA GULF & 3704 & 0 & 17684 & 0 & 21388 \\
\hline TOTAL & - VOLLUME & 18725 & 7347 & 17684 & 1316 & 45072 \\
\hline
\end{tabular}




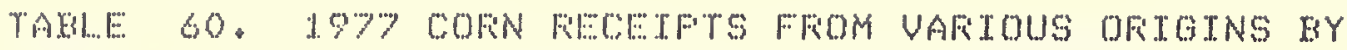
FIFMS TN AREA 2270 \% TLLINOTS

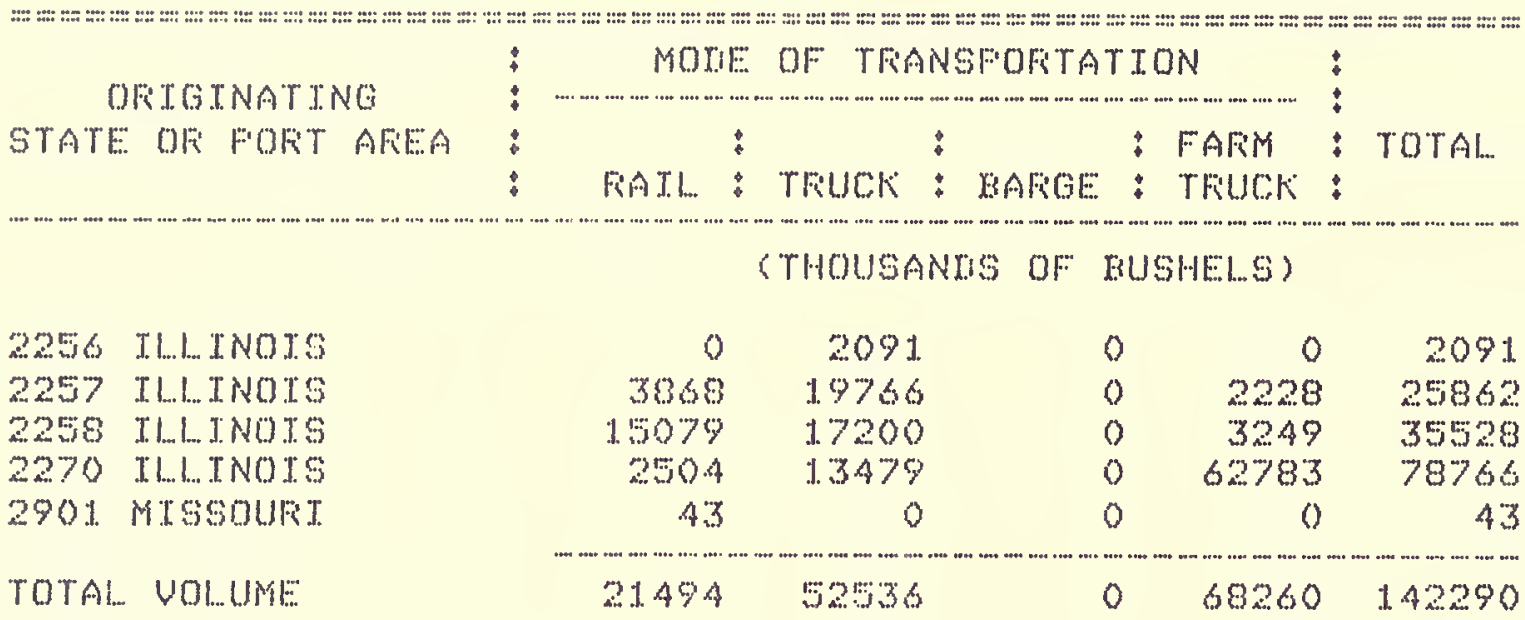

TAELE: 61.1977 COFN SHTFMENTS TO UAFTOUS IEETTNATIONG BY

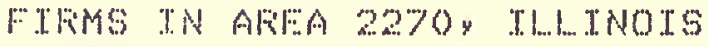

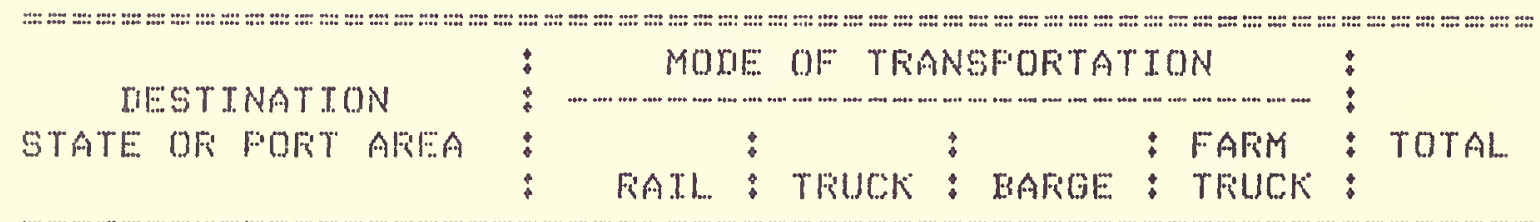

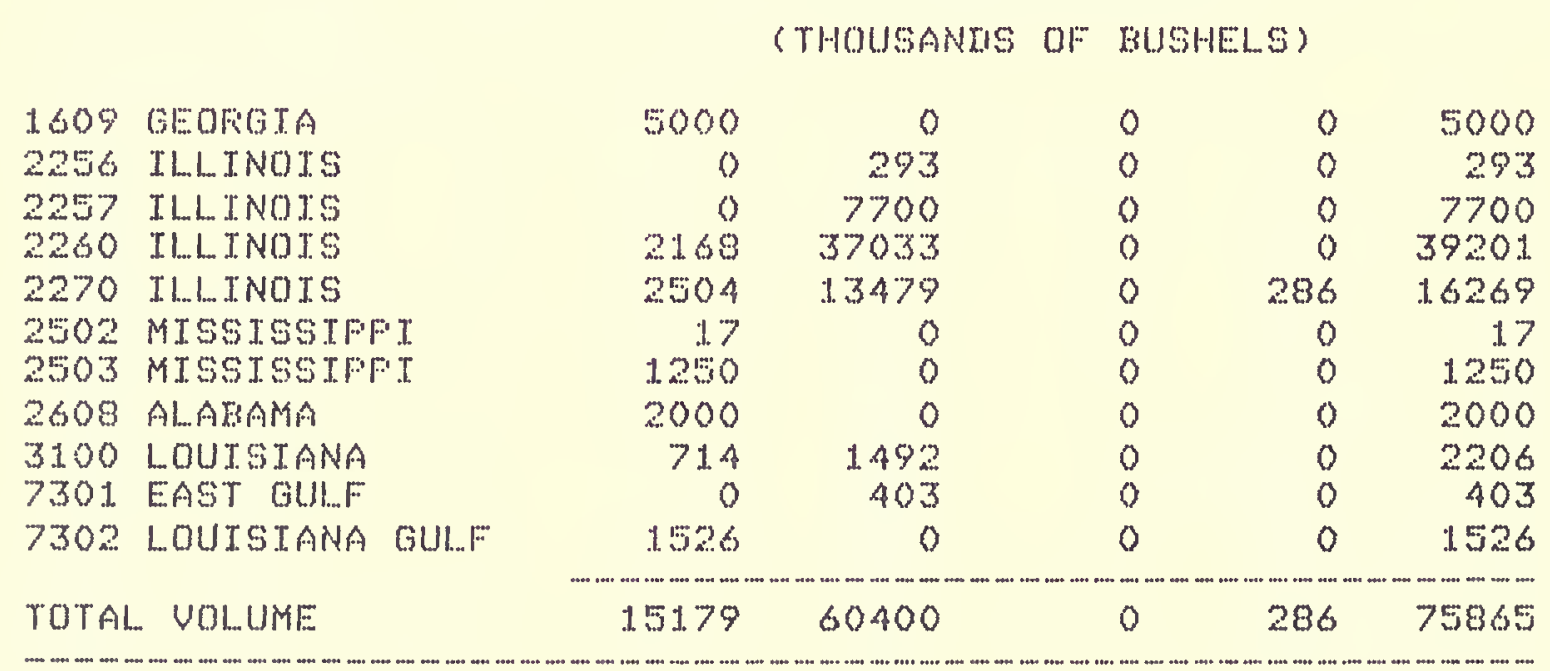


TAFLE 62. 1977 CORN FECFIFTS FFOM UAFTOUS OFIGINS BY FTFMS IN AREA 1.901. TNIIIANA

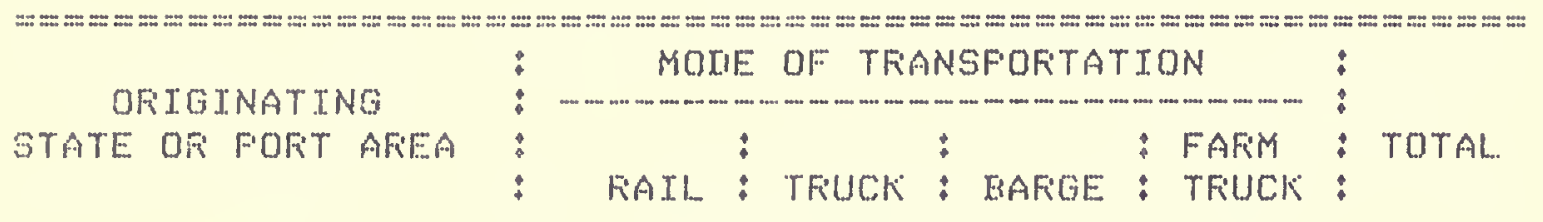

(THOUSANDIS OF RUSHELS)

$\begin{array}{lrrrrr}1825 \text { OHIO } & 0 & 40 & 0 & 0 & 40 \\ 1850 \text { OHIO } & 0 & 3012 & 0 & 0 & 3012 \\ 1901 \text { INIIANA } & 77 & 59388 & 0 & 277367 & 336832 \\ 1902 \text { INIIANA } & 0 & 9154 & 0 & 45577 & 54731 \\ 2000 \text { MTCHIGAN } & 0 & 328 & 0 & 7 & 335 \\ 2103 \text { WISCONSIN } & 0 & 278 & 0 & 0 & 278 \\ 2256 \text { ILLINOTS } & 230 & 0 & 0 & 0 & 230 \\ 2257 \text { TIIITNOSS } & 45 & 0 & 0 & 0 & 45 \\ \text { TOTAL VOLUME } & 39 & 72200 & 0 & 322951 & 395503\end{array}$


TABHE S3. 3977 COFN SHIFMNTS TO UAFIOUS DESTINATIONS BY FTFYS IN AREA 190L, INDIANA

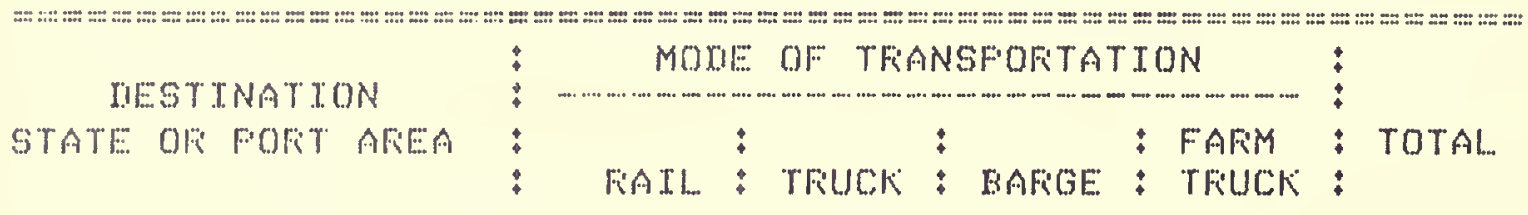

(THOUSANISS OF EUSHELS)

100 MAINE

4OO MASSACHUSETTS

600 CONNL:ETTCLUT

701 NEW YOFIK

703 NEW YOFIK

901 FENNGYLUANTA

903 FENNSYLUANTA

1100 MAFYLAND

1400 NOFITH CAFIOL INA

1.500 SOUTH CAFIDL INA

1603 GEOFGIA

1609 GEOFGIA

1703 FLORIIIA

1825 QHIO

1850 OHIO

1901 INIIANA

1902 INUITANA

1903 INDIANA

2000 MTCHIGAN

2256 TLLINOTS

2257 ILLINOTS

2319 KEENTUCKY

2410 TENNESSEE

2411 TENNESSEE

2502 MISSTSSIFFT

2503 MISSISSIFFI.

2607 ALAEAMA

2608 ALABAMA

3789 TEXAS

7102 CHICAGO AFEA

7201 NOFTH ATLANTTC

7202 SOUTH ATL..ANTIC

7302 LOUTGIANA GUL...F

7303 NO. TEXAS GULFF
625

56

1.901

1.7

9

0

0

42

154

1.44

3046

693

1. 427

0

9

1206

1.0

2014

21196

50

155

188

959

2152

1067

6956

270

0

2590

44202

2712

255

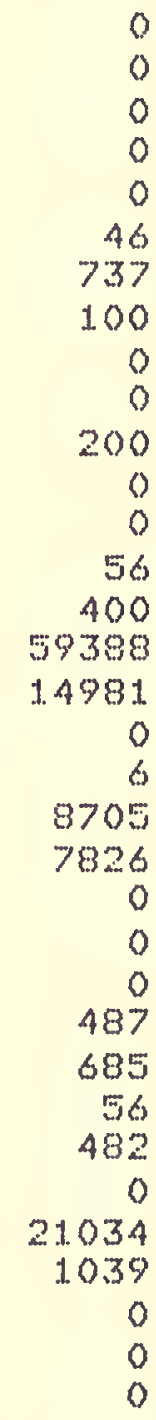

0

0

0

0

46

737

0

0

00

0

56

400

9398

0

6

3705

7826

0

0

0

87

85

56

482

0

4

9

0

0
0

0

0

0

0

0

0

0

0

0

0

0

0

0

0

0

0

0

0

0

0

0

0

0

0

0

0

0

0

0

0

0

0

0
625

56

1901

17

9

46

737

142

154

144

3246

693

1427

56

400

$971 \quad 60436$

$0 \quad 16187$

() 10

$0 \quad 10719$

$0 \quad 29022$

$0 \quad 50$

$0 \quad 155$

$0 \quad 188$

o 1446

$0 \quad 2837$

$0 \quad 1123$

07438

$0 \quad 270$

$0 \quad 21034$

$0 \quad 3629$

$0 \quad 44202$

$0 \quad 2712$

$0 \quad 255$

TOTAL. VOLLUME

$94173 \quad 116228$

0

$971 \quad 211372$ 
TABLE 64. 1977 COFN FECETFYS FROM VAFIOUS OFIGING EY FIFMS IN AFEA 1902, INIIANA

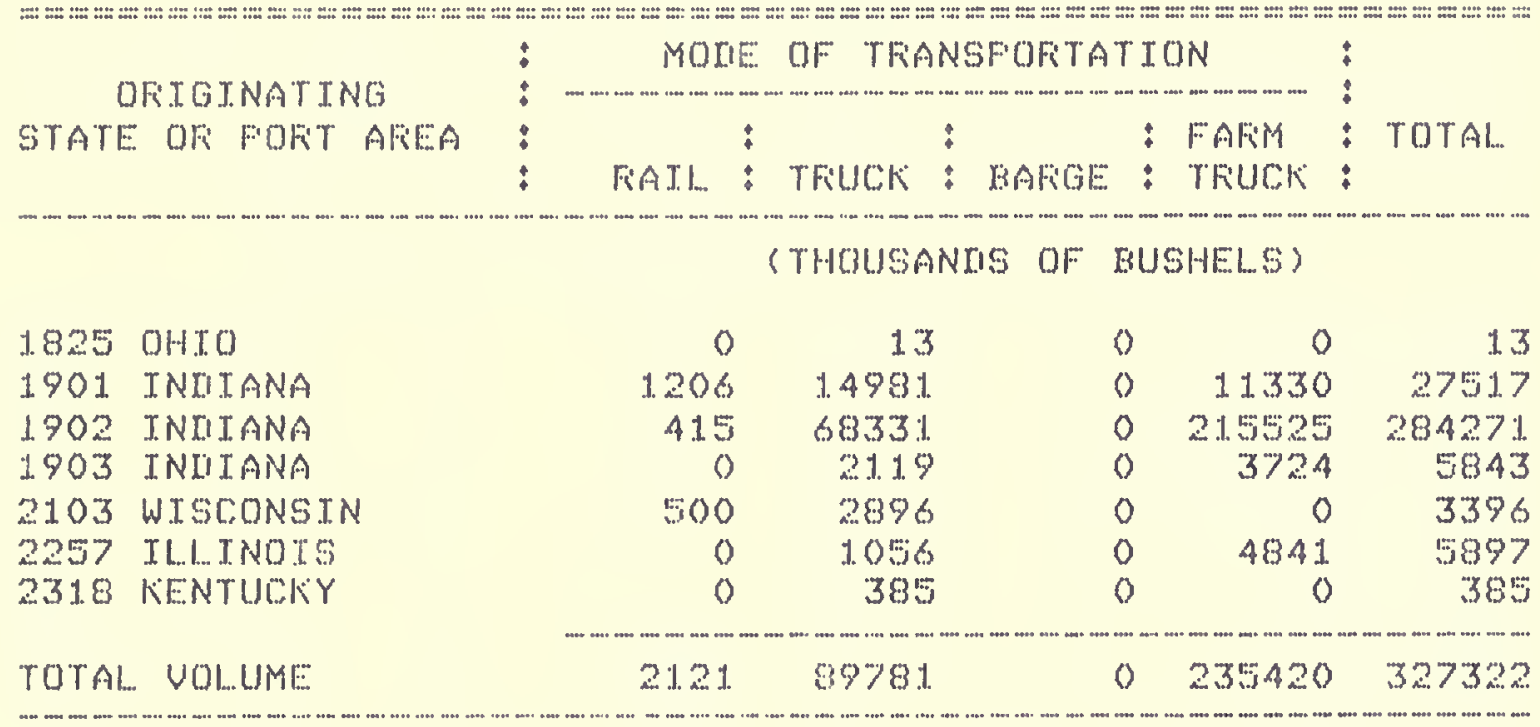


TABLE S5. 1977 CORN SHTPMENTS TO VAFIOUS IESTINATIONS BY FIFMS TN AFEA 1902y TNIITANA

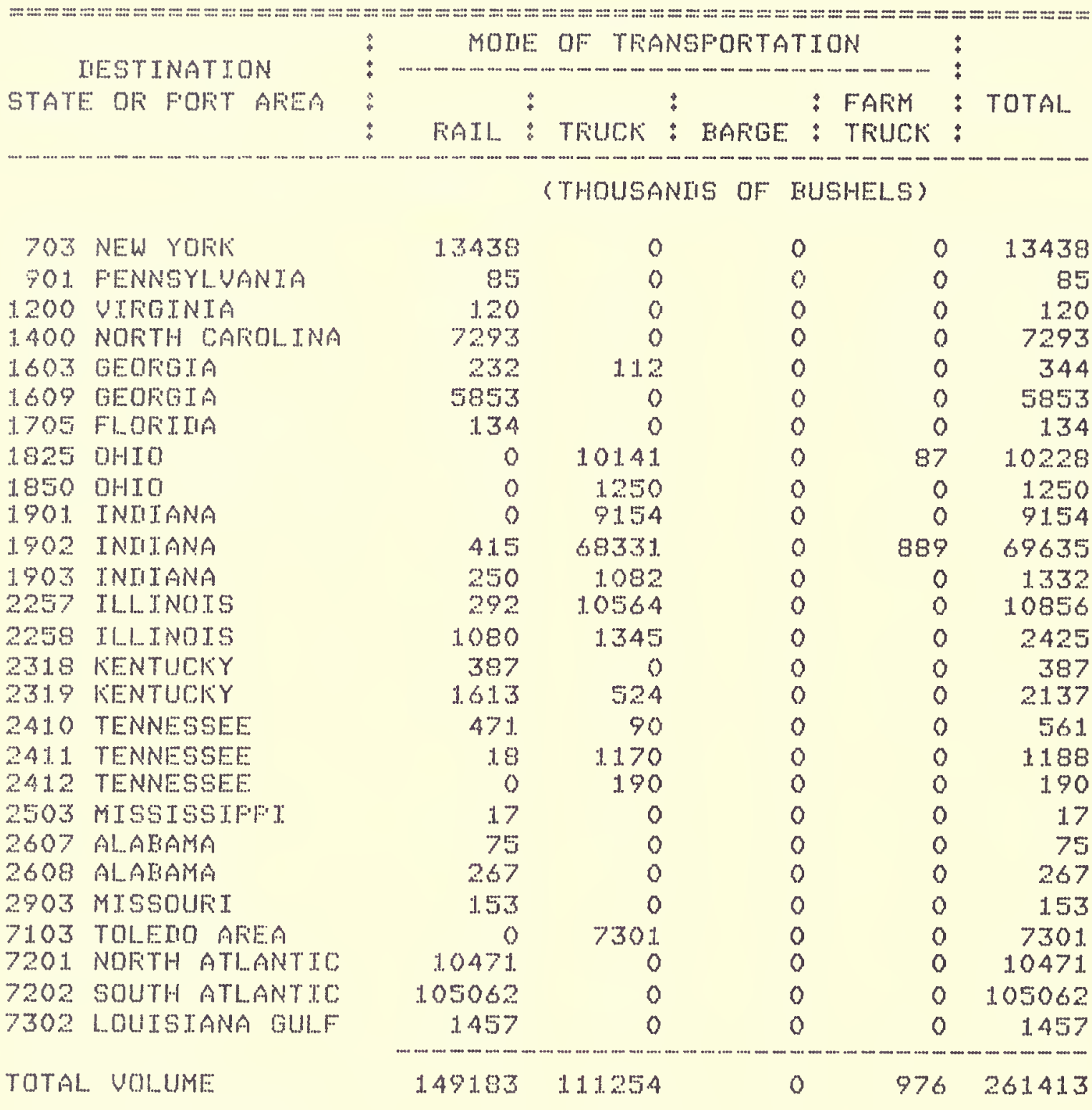


TAELE 66. 1.977 COFN FECETFTS FFOM VAFTOUS OFIGINS BY FIIMS ITN AFEA 1903 y JNITANA

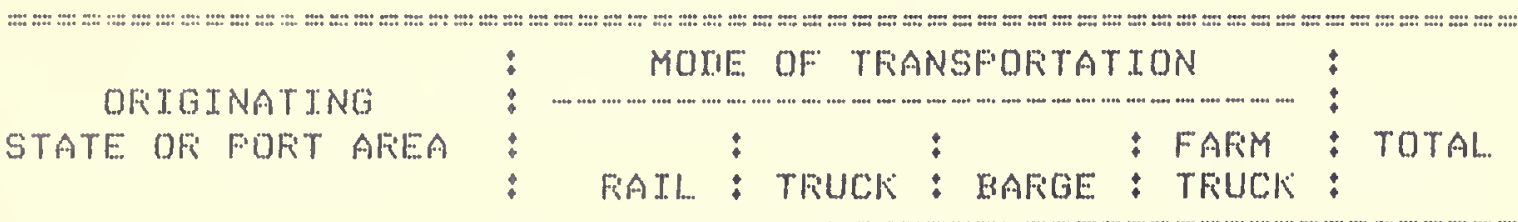

(THOUSANIIS OF EUSHELS)

$\begin{array}{llrrrrr}1901 & \text { INIIANA } & 10 & 0 & 0 & 0 & 10 \\ 1902 & \text { INIIANA } & 250 & 1082 & 0 & 0 & 1332 \\ 1903 & \text { INIIANA } & 144 & 19751 & 0 & 65236 & 85131 \\ 2257 \text { TLLTNOTS } & 3262 & 0 & 0 & 0 & 3262 \\ 2258 \text { TLLINOTS } & 22 & 1880 & 0 & 1902 & 3804 \\ 2259 & \text { ILLINOTS } & 0 & 4551 & 0 & 15268 & 19819 \\ 2318 \text { KIENTUCKY } & 0 & 95 & 0 & 165 & 260 \\ 3501 \text { KIANSAS } & 0 & 80 & 0 & 0 & 80 \\ \text { TOTAL VOLUME } & 3688 & 27439 & 0 & 82571 & 113698\end{array}$

TABLE 67. 1977 COFN SHIFMENTS TO VAFIOUS IIESTINATIONS BY FIFMS IN AFEA 1903 , INTITANA

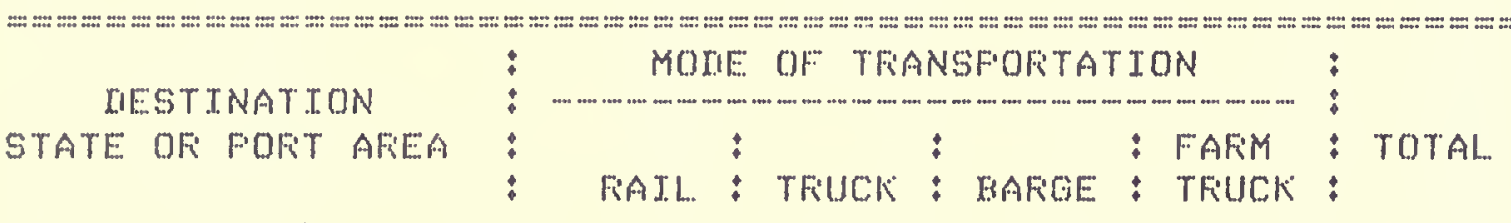

(THOUSANDIS OF EUSHELSS)

\begin{tabular}{|c|c|c|c|c|c|c|}
\hline 1200 & VIFGINIA & 798 & 0 & 0 & 0 & 798 \\
\hline 1400 & NOFTH CAFOLINANA & 703 & 0 & 0 & 0 & 703 \\
\hline 1500 & SOUTH C'AFOLINA & 1.46 & 0 & 0 & 0 & 146 \\
\hline 1603 & GEOFICIA & 4916 & 0 & 0 & 0 & 4916 \\
\hline 1609 & GEDFGIA & 1. 5832 & 0 & 0 & 0 & 15832 \\
\hline 1701 & FLOFIIIIA & 266 & 0 & 0 & 0 & 266 \\
\hline 1703 & FLOFIIIA & 1929 & 0 & 0 & 0 & 1929 \\
\hline 1705 & FLOFIIIIA & 3131 & 0 & 0 & 0 & 3131 \\
\hline 1825 & OHIO & 0 & 1.94 & 0 & 0 & 194 \\
\hline 1902 & INII ANA & 0 & 21.19 & 0 & 0 & 2119 \\
\hline 1903 & INIIIANA & 1.44 & 1.9751 & 0 & 0 & 19895 \\
\hline 2257 & ILLINOIS & 15 & 16 & 0 & 0 & 31 \\
\hline 2258 & TLLINOIS & 527 & 0 & 0 & 0 & 527 \\
\hline 2359 & ILLINOIS & 550 & 0 & 0 & 0 & 550 \\
\hline 2319 & KENTUCK゙Y & 0 & 1800 & 0 & 0 & 1800 \\
\hline 2410 & TENNESSEE & 1917 & 0 & 0 & 0 & 1917 \\
\hline 2411 & TENNESSEE & 3445 & 0 & 0 & 0 & 3445 \\
\hline 2412 & TENNESSEE & 3306 & 0 & 0 & 0 & 3306 \\
\hline 2503 & MISSISSIFFI & 0 & 43 & 0 & 0 & 43 \\
\hline 2607 & ALAEAMA & 3783 & 0 & 0 & 0 & 3783 \\
\hline 2608 & ALABAMA & 2276 & 43 & 9424 & 130 & 11873 \\
\hline 2903 & MISSDUFII & 652 & 6 & 0 & 0 & 658 \\
\hline 7302 & LOUISIANA GUI.FF & 234 & 0 & 15790 & 0 & 16024 \\
\hline TOTAL & VOLUME & 44570 & 23972 & 25214 & 130 & 93886 \\
\hline
\end{tabular}


TAEIE 68. 1977 CORN FECETFTS FFOM UAFTOUS OFIGINS EY FTFMS IN AREA ?BOJ, TOWA

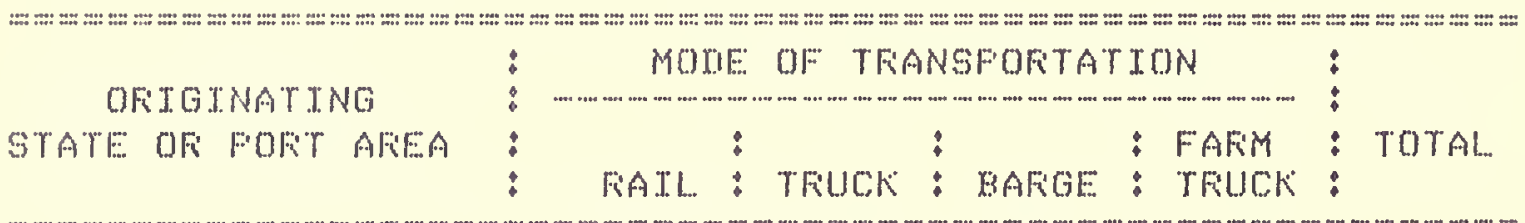

\section{(THOUSANRS OF EUSHELS)}

\begin{tabular}{|c|c|c|c|c|c|}
\hline MINNE:SOTA & $\because 2$ & 359 & 0 & 0 & 41.1. \\
\hline IOWA & 361 & 3341.2 & 0 & 340698 & 374671 \\
\hline TOWA & 211 & 0 & 0 & 0 & 21. 1 \\
\hline SOUTH IMAKOTA & 88 & 179 & 0 & 0 & 267 \\
\hline SOUTH DAKOOTA & 19 & 586 & 0 & 0 & 605 \\
\hline NEEFASSKA & 1554 & 1.837 & 0 & 0 & 3391 \\
\hline NEBKASKIA & 32 & 0 & 0 & 0 & 52 \\
\hline З40: NE:BFIASKIA & 1240 & 1.0 & 0 & $6 \%$ & 131.9 \\
\hline TTAL. VOL..UML: & 3777 & 36383 & 0 & 340767 & 380927 \\
\hline
\end{tabular}


TABLE 6\%. 1977 COFIN SHIFMENTS TO VARIOUS LIESTINATIONS RY FTRMG IN AFEA 2801, IOWA

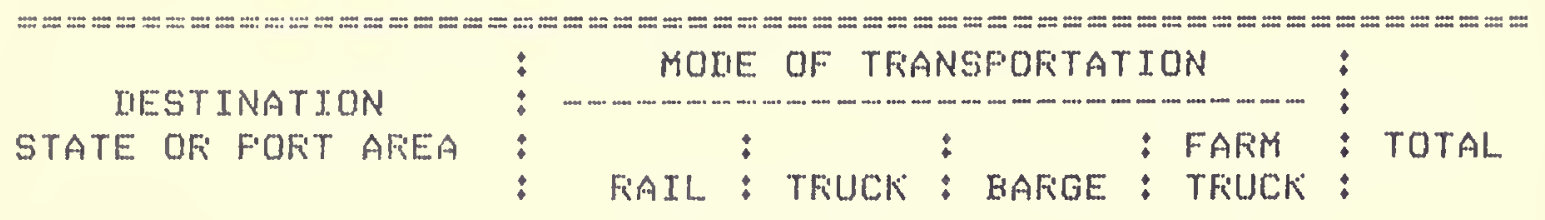

\{THOUSANIIS OF BUSHELS?

\begin{tabular}{|c|c|c|c|c|c|c|}
\hline 2256 & JLLINOTS & 0 & 841 & 0 & 0 & 841 \\
\hline 2257 & ILLJNOIS & 501 & 0 & 0 & 0 & 501 \\
\hline 2260 & ILLINOTSS & $4 A 4$ & 0 & 0 & 0 & 444 \\
\hline 2608 & ALAEAMA & 12 & 0 & 0 & 0 & 12 \\
\hline 2704 & MINNESOTA & 0 & 2336 & 0 & 0 & 2336 \\
\hline 2705 & MINNESOTA & 0 & 128 & 0 & 0 & 128 \\
\hline 2801 & TOWA & 561 & 33412 & 0 & 142175 & 176148 \\
\hline 2802 & IOWA & 0 & $2 \div 87$ & 0 & 0 & 2587 \\
\hline 2803 & IOWA & 3647 & 3633 & 0 & 0 & 7280 \\
\hline 2900 & MISSOUFI & 340 & 271 & 0 & 0 & 611 \\
\hline 2901 & MISSOUFI & 6765 & 2335 & 0 & 0 & 9100 \\
\hline 2903 & MISSOUFI & 146 & 2366 & 0 & 0 & 2512 \\
\hline 2904 & MISSOUFII & 143 & 628 & 0 & 0 & 771 \\
\hline 3005 & AFKCANSAS & 804 & 0 & 0 & 0 & 804 \\
\hline 3016 & AFIKANSAS & 9061 & 4567 & 0 & 0 & 13628 \\
\hline 3017 & AFKIANSAS & 4751 & 0 & 0 & 0 & 4751 \\
\hline 3038 & AFKKANSAS & 536 & 0 & 0 & 0 & 536 \\
\hline 3100 & LOUISIANA & 1910 & 0 & 0 & 0 & 1910 \\
\hline 3403 & NEBFIASKIA & 11 & 2310 & 0 & 0 & 2321 \\
\hline 3404 & NEEFIASKRA & 219 & 8 & 0 & 0 & 227 \\
\hline 3405 & NEEFIASKIA & 570 & 4899 & 0 & 0 & 5469 \\
\hline 3503 & KIANSAS & 2087 & 602 & 0 & 0 & 2689 \\
\hline 3602 & OKLLAHOMA & 36 & 3 & 0 & 0 & 39 \\
\hline 3604 & OKKLAHOMA & 274 & 0 & 0 & 0 & 274 \\
\hline 3710 & TEXAS & 778 & 0 & 0 & 0 & 778 \\
\hline 3712 & TEXAS & 143 & 0 & 0 & 0 & 143 \\
\hline 3723 & TEXAS & 300 & 0 & 0 & 0 & 300 \\
\hline 3745 & TEXAS & 2131 & 312 & 0 & 0 & 2443 \\
\hline 3789 & TEXAS & 560 & 0 & 0 & 0 & 560 \\
\hline 4.400 & AFIIZONA & 0 & 1.56 & 0 & 0 & 156 \\
\hline 4500 & WASHINGTON & 40 & 0 & 0 & 0 & 40 \\
\hline 4704 & CAL IFOFINIA & 1620 & 0 & 0 & 0 & 1620 \\
\hline 7101 & IIULUTH-SUFEFIIOF & 51 & 0 & 0 & 0 & 51. \\
\hline 7102 & CHICAGO AFIEA & 3457 & 1341 & 0 & 0 & 4798 \\
\hline 7301 & EAST GULF & 308 & 0 & 0 & 0 & 308 \\
\hline 7302 & LOUISIANA GULF & 25314 & 0 & 2760 & 0 & 28074 \\
\hline 7303 & NO. TEXAS GUULF & 27438 & 0 & 0 & 0 & 27438 \\
\hline 7402 & FUGET SOUNI & 4388 & 0 & 0 & 0 & 4388 \\
\hline TAL. & UOLUME & 99346 & 62735 & 2760 & 142175 & 307016 \\
\hline
\end{tabular}


TALLE 70, 1977 COFN FECETFTS FROM VARTOUS OFIGTNS BY FTFMS IN AREA 28O2, TOWA

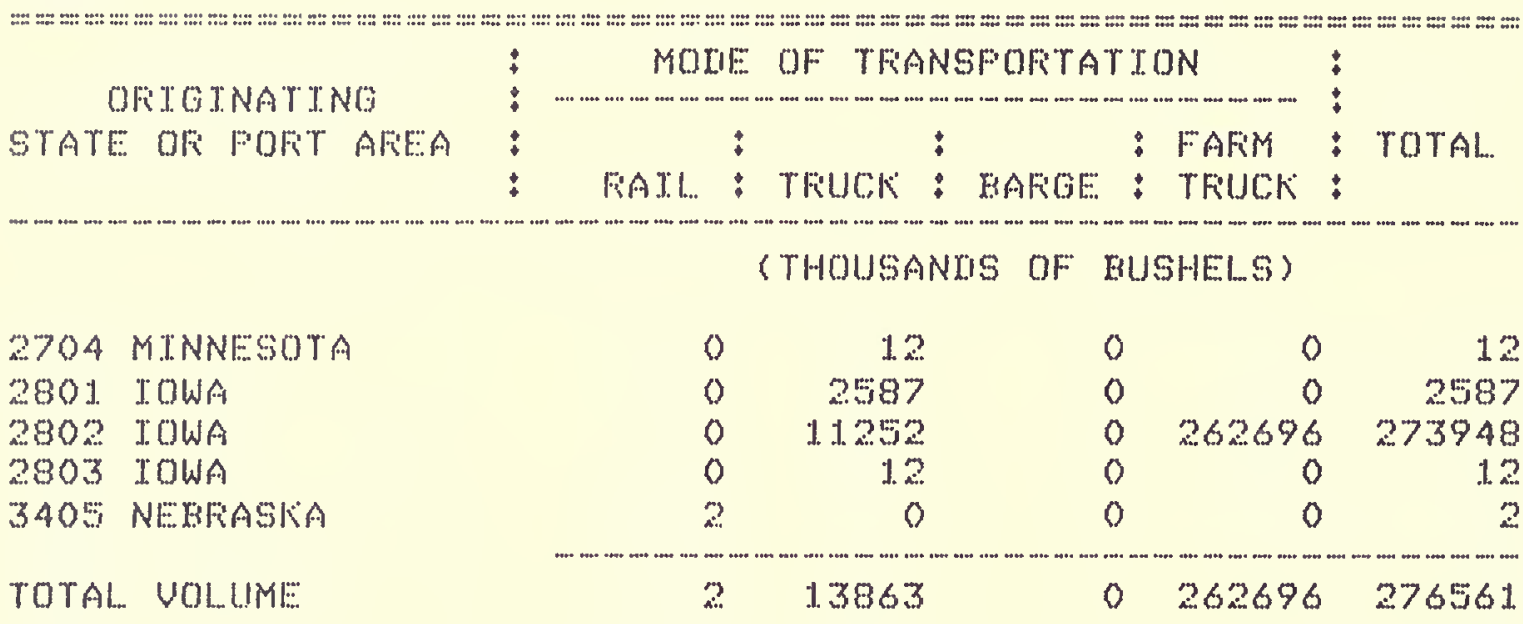


TAELE 71. 1977 COFN SHTFMENTS TO VAFIOUS DESTINATIONS BY FT.FIMS IN AFEA 2802, TOWA

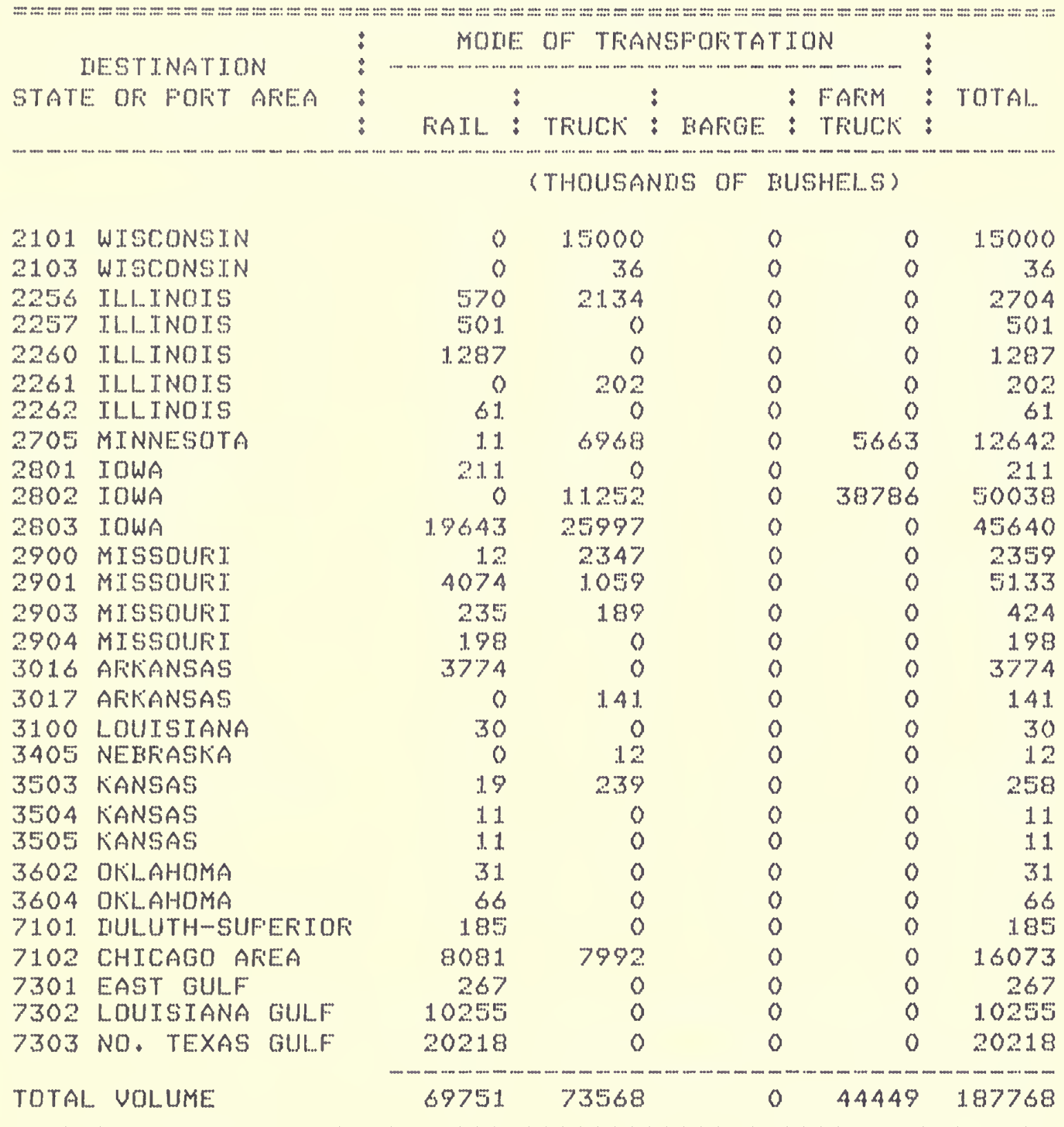


TABLE 72. 1977 COFN FECETFTS FFOM VAFIOUS ORIGINS EY FIFMS IN AREA 2803, IOWA

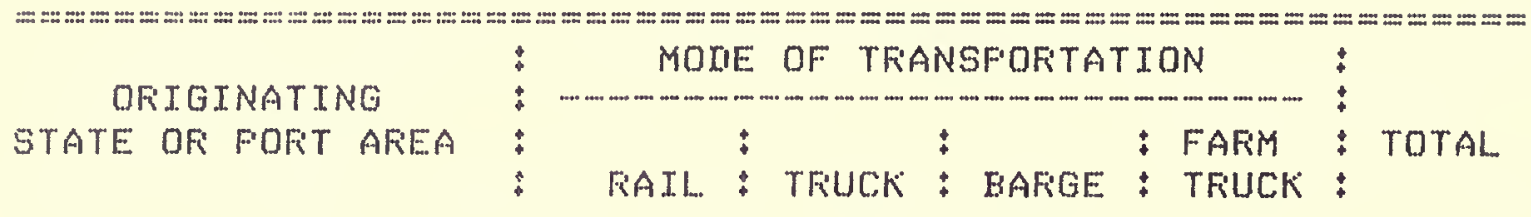

(THOUSANDS OF EUSHELS)

$\begin{array}{ll}2103 & \text { WISCONSIN } \\ 2256 & \text { ILI.. INOIS } \\ 2260 & \text { ILLINOIS } \\ 2261 & \text { ILLINOIS } \\ 2704 & \text { MINNESOTA } \\ 2705 & \text { MINNESOTA } \\ 2801 & \text { IOWA } \\ 2802 & \text { IOWA } \\ 2803 & \text { IOWA } \\ 2902 & \text { MISSOURI }\end{array}$

TOTAL VOLUME

$\begin{array}{rrrrr}17 & 4304 & 0 & 0 & 4321 \\ 125 & 5904 & 0 & 0 & 6029 \\ 0 & 124 & 0 & 0 & 124 \\ 0 & 58 & 0 & 0 & 58 \\ 0 & 107 & 0 & 0 & 107 \\ 179 & 0 & 0 & 0 & 179 \\ 3647 & 3633 & 0 & 0 & 7280 \\ 19643 & 25997 & 0 & 0 & 45640 \\ 11658 & 181884 & 0 & 156050 & 349592 \\ 79 & 625 & 0 & 0 & 723 \\ 35367 & 222636 & 0 & 156050 & 414053\end{array}$


TAELE 73. 1977 COFN SHIFMENTS TO VARIOUS DIESTINATIONS BY FIFIMS IN AFEA 2803, IOWA

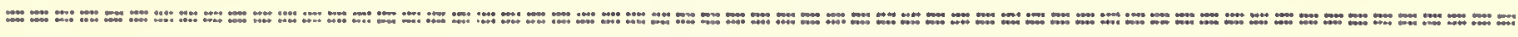

DESTINATION

STATE OF FOFT AFEA
MODE OF TFANSFORTATION

: FAFIM FAIL : TRUCK : BARGE : TRUCK :

TOTAL..

\section{(THOUSANIS OF RUSHELS)}

1609 GEOFGIA

2101 WISCONSIN

2103 WISCONSIN

2256 ILLINOIS

2260 ILLINOIS

2261 ILLINOIS

2410 TENNESSEE

2412 TENNESSEE

2502 MISSISSIFFT

2503 MISSISSIFFI

2608 ALABAMA

2705 MINNESOTA

2802 IOWA

2803 IOWA

2901 MISSOUFI

2902 MISSOUFI

2903 MISSOURT

3038 ARKANSAS

3504 KANSAS

7102 CHICAGO AREA

7302 LOUISIANA GULF

7303 NO. TEXAS GULFF

TOTAL VOLUME
81.5

0

0

304

1.732

0
0

360

8793

3087

0

8399
0

0

0

0

0

0

815

360

8793

3391

1732

8399

50

38

COMEINEN TO AVOTI DISCLOSURE 5894

144

354

530

1. $658 \quad 181884$

1.294

0

0

0

30

7300

768

12906

0
530
1.2

372

392

79

16

0

4421
354

0

0

0

0

0

0

0

0

0

153689
12

0

24174

0

0

217716

1666

392

79

16

30

11721

154457

12906

$\begin{array}{lll}37357 & 213833 & 154131\end{array}$

$24174 \quad 429495$

TABLE 74. 1977 COFN RECEIFTS FFIOM UARIOUS ORIGINS EY FIFIMS IN AREA 3500, KANSAS

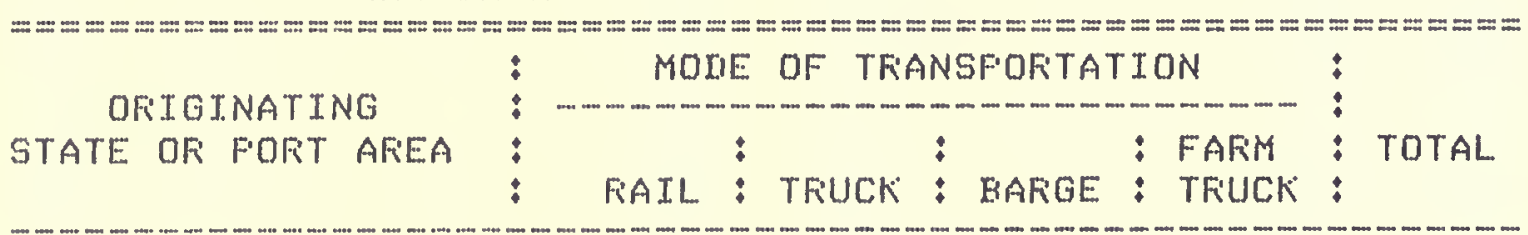
(THOUSANDS OF EUSHELS)

3501 KANSAS

3503 KANSAS

3504 KANSAS

3505 KANSAS

\begin{tabular}{rrrrr}
3057 & 25595 & 0 & 0 & 28652 \\
394 & 0 & 0 & 0 & 394 \\
0 & 1298 & 0 & 0 & 1298 \\
0 & 194 & 0 & 0 & 194 \\
\hline 3451 & 27087 & 0 & 0 & 30538
\end{tabular}

TOTAL VOLUME

$3451 \quad 27087$ 30538 
TABLE 75. 1977 COFN FECETFTS FFOM VAFTOUS ORTGINS BY FTEMS IIN AKEA 3 BO 1 , KANSAS

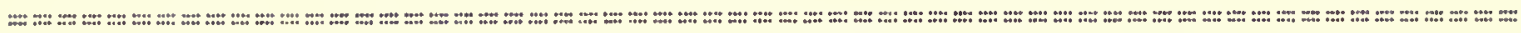

OFTGTNATING

STATE OR FOFT AFEA
MODE OF TFANSFOFTATION

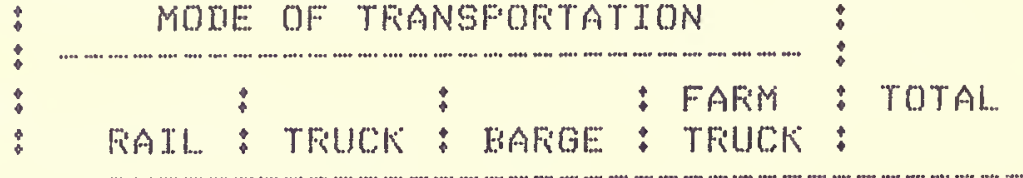

(THCUSANDS OF BUSHELS)

3401 NEBRASKRA

3AO4 NEKLASKA

3405 NEBFASKA

3

$3711 . T E X A S$

TOTAI.., VOLLUME

$\begin{array}{rrrrr}0 & 425 & 0 & 240 & 665 \\ 6690 & 0 & 0 & 267 \% & 9355 \\ 0 & 0 & 0 & 487 & 497 \\ 0 & 0 & 0 & 64191 & 64191 \\ 101 & 0 & 0 & 0 & 101 \\ 6791 & 425 & 0 & 67593 & 74799\end{array}$

TAELE: 76. I977 COFN SHIFMENTS TO WAFEOUS RESTINATIONS BY FUFU TH AFEA 3501 Y KNANSAS

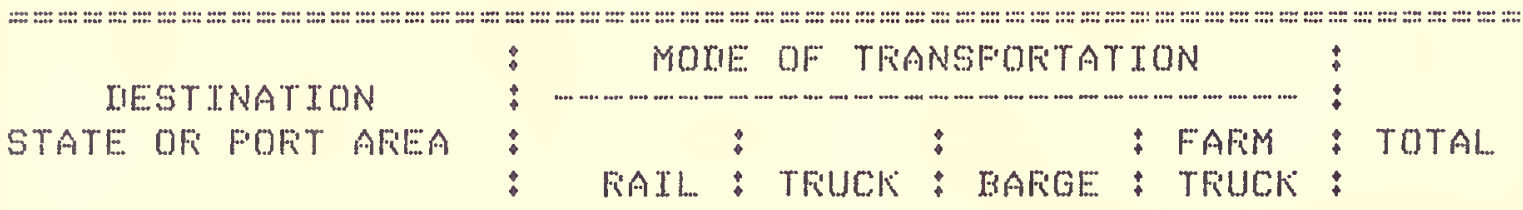

(THOUSANIS OF RUSHELS)

\begin{tabular}{|c|c|c|c|c|c|c|}
\hline 1.903 & INIIIANA & 0 & 80 & 0 & 0 & 80 \\
\hline 2901 & MISSOUFI. & 0 & 9 & 0 & 0 & 9 \\
\hline 3500 & KEANSAS & 3057 & 20595 & 0 & 0 & 28652 \\
\hline 3502 & KAANSAS & 1. 25 & 319 & 0 & 0 & 444 \\
\hline 3503 & KANSAS & 873 & 57 & 0 & 0 & 930 \\
\hline 3504 & KIANSAS & 2166 & 501 & 0 & 0 & 2667 \\
\hline 3505 & KAANSAS & 610 & 274 & 0 & 0 & 834 \\
\hline 3711 & TEXAS & 0 & 2420 & 0 & 0 & 2420 \\
\hline 3745 & TEXAS & 60 & 1889 & 0 & 0 & 1.949 \\
\hline 4000 & COLOFATIO & 234 & 908 & 0 & c & 1142 \\
\hline 4704 & CALIFOFINTA & 628 & 0 & 0 & 0 & 628 \\
\hline TOTAL & UOLUME & 7753 & 32052 & 0 & 0 & 3880 \\
\hline
\end{tabular}


TARLE 77. 1977 COFIN FECEIFTS FFOM UAFIOUS OFIGINS EY FIFMS TN AFEA 3502 , KIANSAS

\begin{tabular}{|c|c|c|c|c|c|c|c|c|}
\hline \multirow{3}{*}{$\begin{array}{l}\text { OFIGINATING } \\
\text { STATE OF FOFT AFEA }\end{array}$} & \multirow{3}{*}{$\vdots$} & MODE O & E OF TFA & \multicolumn{3}{|c|}{ TFANSFOFITATION } & : & \multirow{3}{*}{ TOTAL } \\
\hline & & & : & $:$ & & FAFM & : & \\
\hline & & FIAIL. & : TFUUCK & : HAFIGE & & TRUCK & : & \\
\hline & & \multicolumn{4}{|c|}{ (THOUSANDIS OF E } & \multicolumn{2}{|c|}{ BUSHELS) } & \\
\hline 3200 NORTH IIAKEOTA & & 0 & $\Delta$ & & 0 & 0 & 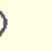 & 4 \\
\hline 3301 SOUTH IIAKKOTA & & 0 & 4 & & 0 & 0 & ) & 4 \\
\hline 3403 NEBFIASKIA & & 0 & 463 & & 0 & 0 & ) & 463 \\
\hline 3404 NEEFIASKKA & & 223 & 7491 & & 0 & 0 & 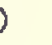 & 7714 \\
\hline 3405 NEEFASK゙A & & 2737 & 152 & & 0 & 0 & 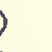 & 2889 \\
\hline 3501 KIANSAS & & 125 & 31.9 & & 0 & 0 & ) & 444 \\
\hline 3502 K゙ANSAS & & 73 & 81 & & 0 & 9236 & & 9390 \\
\hline 3503 K゙ANSAS & & 209 & 0 & & 0 & 0 & 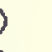 & 209 \\
\hline 3504 KAANSAS & & 0 & 1.0 & & 0 & 0 & 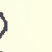 & 10 \\
\hline KANSAS & & 71 & 0 & & 0 & 0 & ) & 71 \\
\hline TOTAL. VOLUME & & 3438 & 8524 & & 0 & 9236 & & 211.98 \\
\hline
\end{tabular}

TAELE 79. 1977 COFN SHIFMENTS TO VAFTOUS TIESTINATIONS BY FIFIYS TN AFEA 3502 , KANSAS

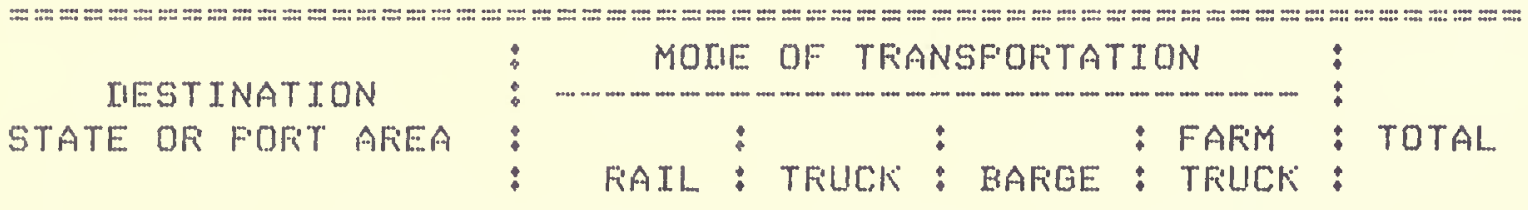

(THOUSANDIS OF EUSHELS)

\begin{tabular}{|c|c|c|c|c|c|c|}
\hline 2901 & MISSOURI & 48 & 56 & 0 & 0 & 104 \\
\hline 3502 & KANSAS & 73 & 81 & 0 & 0 & 154 \\
\hline 3503 & KIANSAS & 275 & 185 & 0 & 0 & 460 \\
\hline 3504 & KANSAS & 0 & 522 & 0 & 0 & 522 \\
\hline 3505 & KANSAS & 1.25 & 37 & 0 & 0 & 162 \\
\hline 3602 & OK゙L...HOMA & 0 & 246 & 0 & 0 & 246 \\
\hline 3712 & TEXAS & 25 & 418 & 0 & 0 & 443 \\
\hline 4400 & AFIIZONA & 164 & 4 & 0 & 0 & 168 \\
\hline 4600 & OFEGON & 147 & 0 & 0 & 0 & 147 \\
\hline 4701 & CAL IFOFINTA & 73 & 0 & 0 & 0 & 73 \\
\hline 4703 & CALIFOFINIA & 69 & 0 & 0 & 0 & 69 \\
\hline 4704 & CALLIFOFINIA & 220 & 0 & 0 & 0 & 220 \\
\hline 7303 & NO. TEXAS GULF & 199 & 0 & 0 & 0 & 199 \\
\hline
\end{tabular}


TABLE 79, 1977 COFN FECFIFTS FFOM VAFIOUS OFIGINS BY FTFMS IN AFEA 3503 , KANSAS

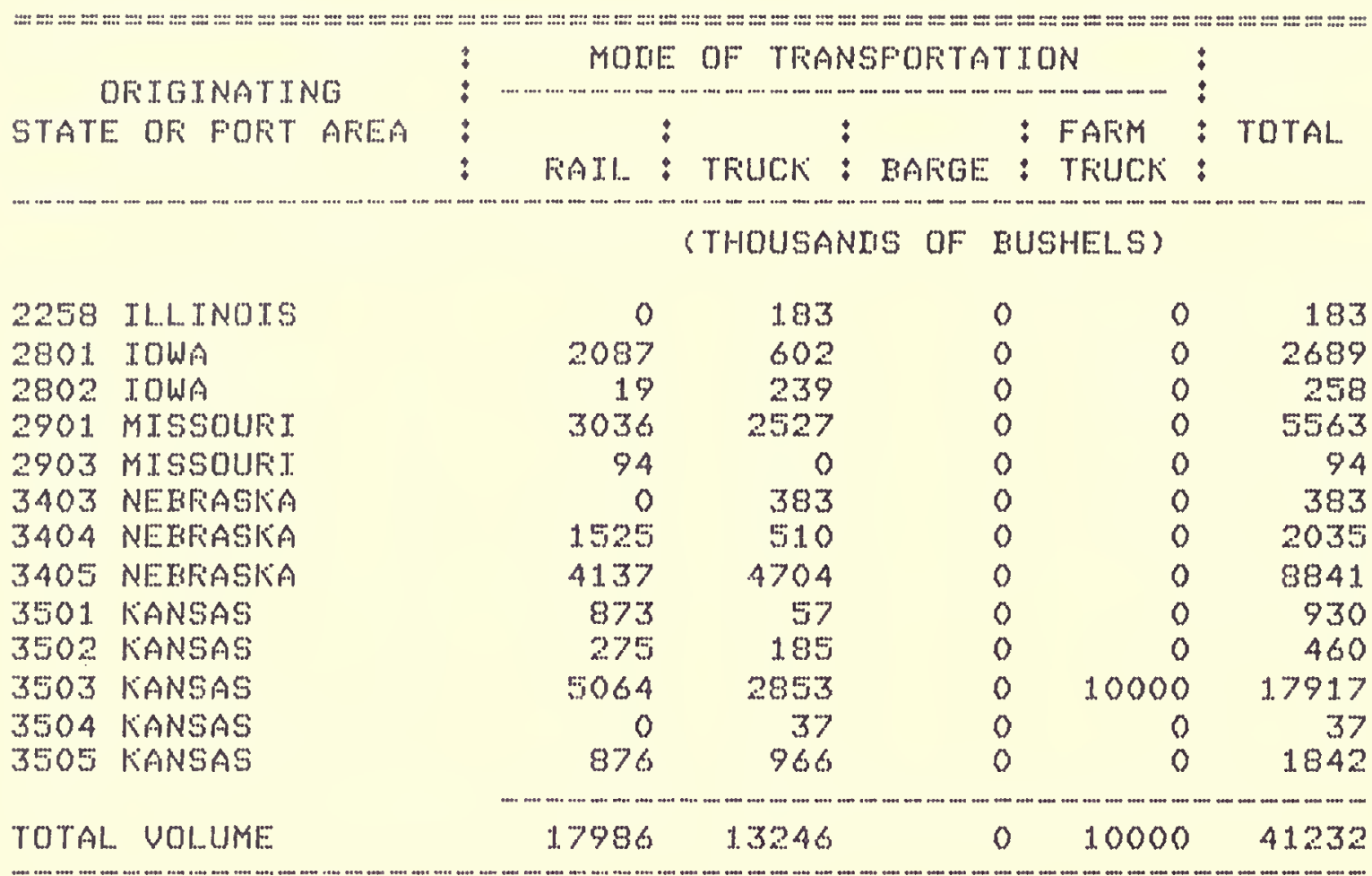


TABLE 30. 1977 COFN SHTFMENTS TO UAFIOUS DESTINATTONS BY FTFMS IN AFEA 35OZ, KEANSAS

\begin{tabular}{|c|c|c|c|c|c|c|}
\hline MESTINATTON & $\vdots$ & MOIIE: & OF TFi & INSFOFTAY & ION & \multirow{3}{*}{ TotAl. } \\
\hline STATE OF FOFT AFEA & : & ! & & : & & \\
\hline & ! & FiATI... & TFUし:バ & BAFICE & : & \\
\hline
\end{tabular}

(THOUSANTIS OF RUSHIEI..S)

\begin{tabular}{|c|c|c|c|c|c|c|}
\hline 2411 & TENNESSEE & 1221 & 0 & 0 & 0 & 1. 221 \\
\hline 2901 & MISSOUFI & 776 & 43 & 0 & 0 & 81.9 \\
\hline 2904 & MISSOURI & 364 & 0 & 0 & 0 & 364 \\
\hline 3005 & AFIKANSAS & 1547 & 0 & 0 & 0 & 1547 \\
\hline 3016 & AFIKANSAS & 7970 & 0 & 0 & 0 & 7970 \\
\hline 3038 & AFIKANSAS & 434 & 0 & 0 & 0 & 434 \\
\hline 3100 & LOUISIANA & 1247 & 0 & 0 & 0 & 1247 \\
\hline 3500 & KANSAS & 394 & 0 & 0 & 0 & 394 \\
\hline 3502 & KIANSAS & 209 & 0 & 0 & 0 & 209 \\
\hline 3503 & KANSAS & 5064 & 2833 & 0 & 0 & 7917 \\
\hline 3505 & K゙ANSAS & 735 & 1008 & 0 & 0 & 1.743 \\
\hline 3602 & OKL.AHOMA & 442 & 490 & 0 & 0 & 932 \\
\hline 3604 & OKLAHOMA & 133.1 & 0 & 0 & 0 & 1331 \\
\hline 3745 & TEXAS & 953 & 0 & 0 & 0 & 953 \\
\hline 4400 & AFT:ZONA & 988 & 23 & 0 & 0 & 1011 \\
\hline 4704 & CAILIFORNIA & 442 & 0 & 0 & 0 & 442 \\
\hline 7301 & EAST GULFF & 120 & 0 & 0 & 0 & 120 \\
\hline 7302 & LOUISIANA GULF & 1644 & 0 & 0 & 0 & 1644 \\
\hline & NO. TEXAS CULFF & 21.96 & 0 & 0 & 0 & 2196 \\
\hline 7304 & SO. TEXAS GULF & 501 & 0 & 0 & 0 & 501 \\
\hline 9000 & EXFOFT & 260 & 0 & 0 & 0 & 260 \\
\hline |TAl & VOLLME & 28838 & 4417 & 0 & 0 & 33255 \\
\hline
\end{tabular}

TAELE 31. 1977 COFN RECETFTS FFOM VAFTOUS OFIGTNS BY FIFEMS IN AREA 35OA Y KANSAS

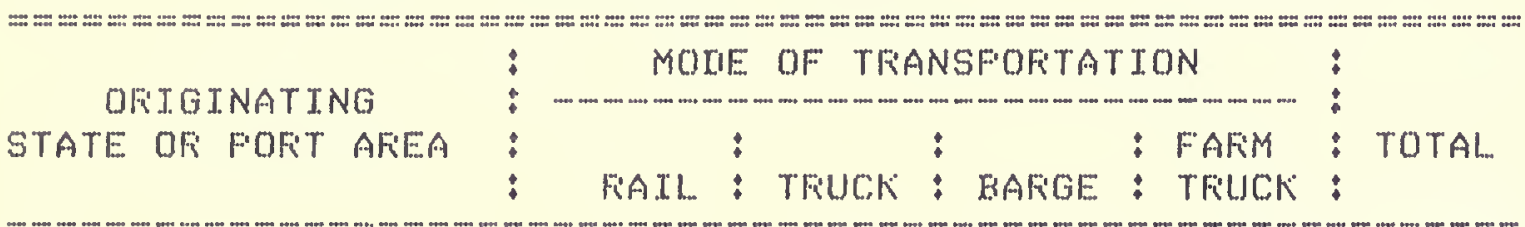

(THOUSANISS OF BUSHELS)

\begin{tabular}{|c|c|c|c|c|c|}
\hline 2802 IOWA & 11 & 0 & 0 & 0 & 11 \\
\hline 2803 IOWA & 30 & 0 & 0 & 0 & 30 \\
\hline 3403 NEEFIASKA & 89 & 0 & 0 & 0 & 89 \\
\hline 34OA NEEFIASKIA & 70 & 40 & 0 & 0 & 110 \\
\hline 3405 NEEFIASKA & 89 & 547 & 0 & 0 & 636 \\
\hline 3501 K゙ANSAS & 2166 & 501 & 0 & 0 & 2667 \\
\hline 3502 KANSAS & 0 & 522 & 0 & 0 & 522 \\
\hline 3504 KNANSAS & 387 & 216 & 0 & 8762 & 9365 \\
\hline 3505 KANSAS & 131 & 21 & 0 & 0 & 152 \\
\hline OLUME & 2973 & 1847 & 0 & 8762 & \\
\hline
\end{tabular}


TABLE 82, 1977 COFN SHIFMENTS TO VAFIOUS IIESTINATIONS BY FIFMS TN AFEA 3504, KIANSAS

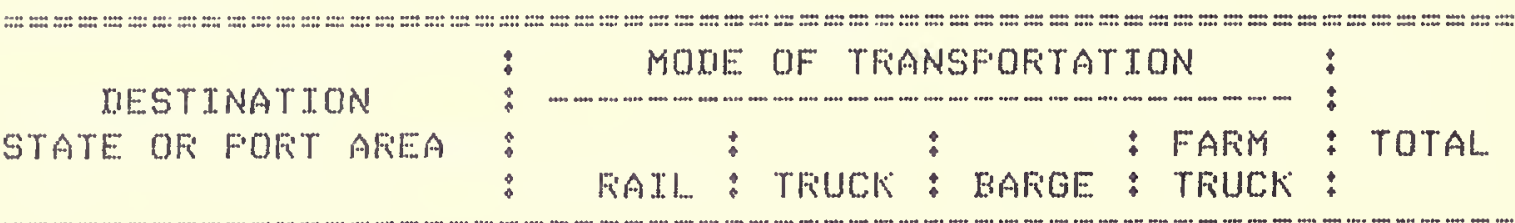

(THOUSANLS OF BUSHELS)

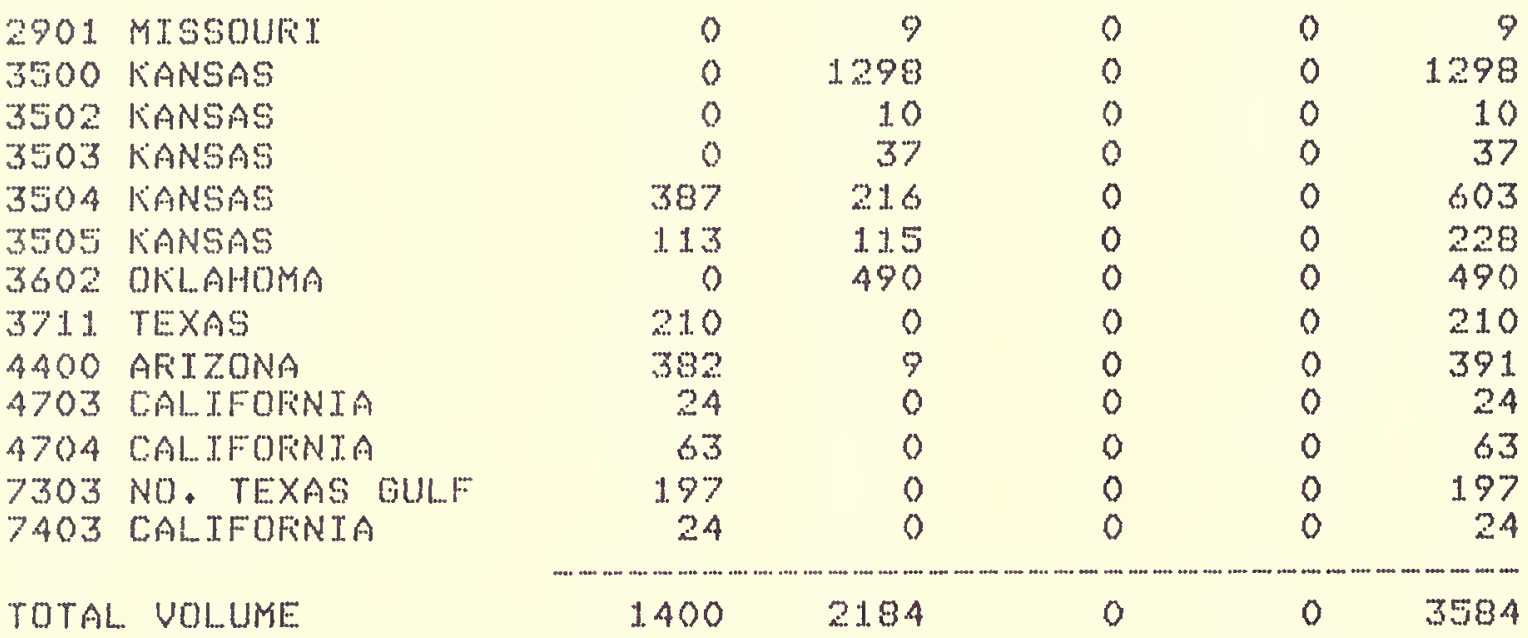

TAELE 33. 1977 COFN FECETFTS FFOM UAFIOUS OFIGINS BY FTIMS TN AFEA 3505 , KAANSAS

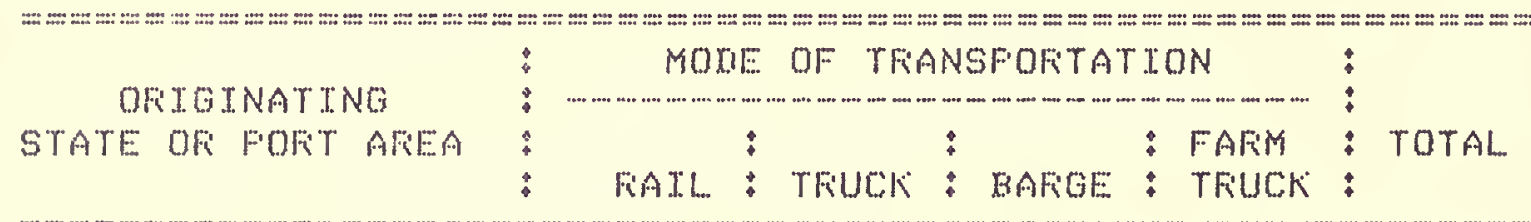

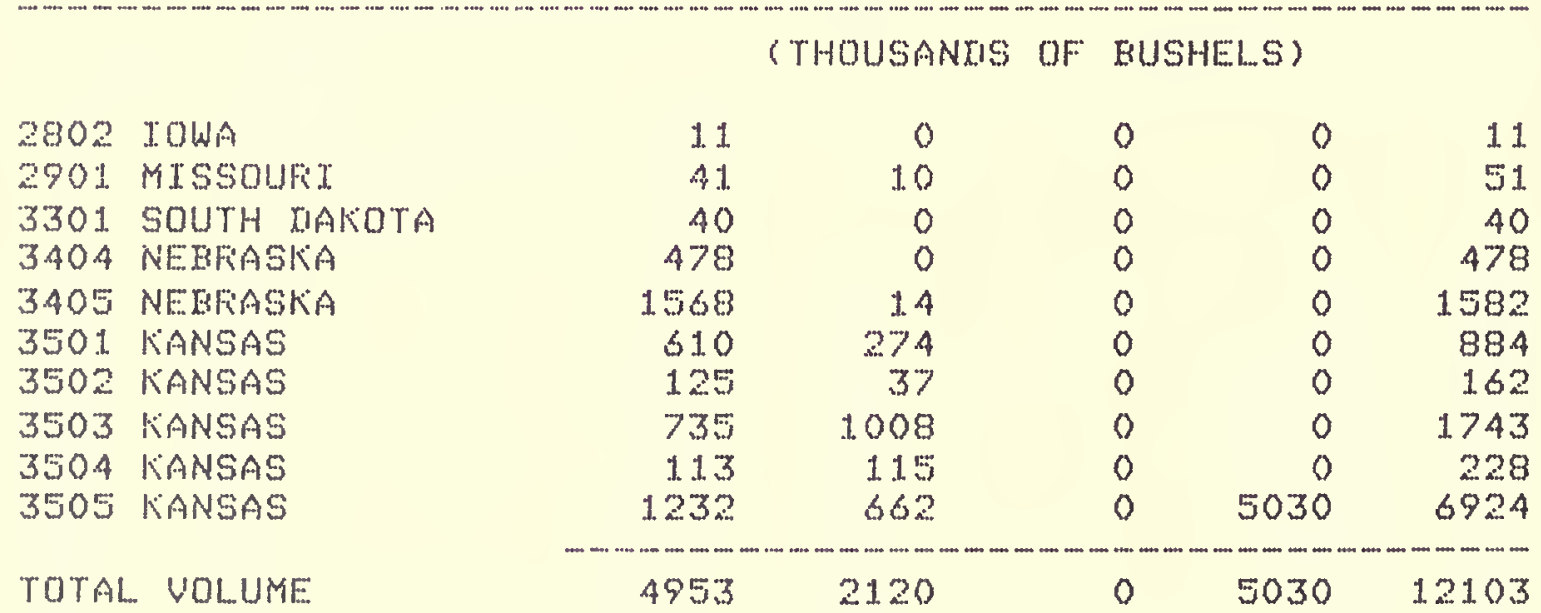


TABLE 84. 1977 COFN SHIFMENTS TO UAFTOUS RESTTNATTONS BY FIFMS IN AFEA 3505 y K゙ANSAS

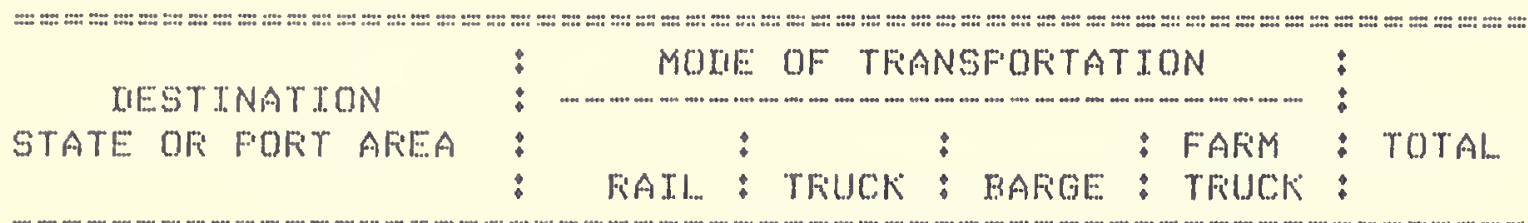

(THOUSANISS OF BUSHELSS)

\begin{tabular}{|c|c|c|c|c|c|c|}
\hline 2411 & TENNESSEE & 68 & 0 & 0 & 0 & 68 \\
\hline 2502 & MISSISSTFI & 68 & 0 & 0 & 0 & 68 \\
\hline 2901. & MISSOUFI: & 634 & 1. & 0 & 0 & 786 \\
\hline 3005 & AFKIANSAS & 66 & 0 & 0 & 0 & 66 \\
\hline 3016 & AFKHANSAS & 620 & 0 & 0 & 0 & 620 \\
\hline 3038 & AFIKANSAS & 61 & 0 & 0 & 0 & 61 \\
\hline 3100 & LOUTSTANA & 68 & 0 & 0 & 0 & 68 \\
\hline 3405 & NEBFASK゙A & 7.1 & 0 & 0 & 0 & 71 \\
\hline 3000 & K゙ANSAS & 0 & 194 & 0 & 0 & 194 \\
\hline 3502 & KANSAS & 71 & 0 & 0 & 0 & 71 \\
\hline 3503 & KNANSAS & 876 & 966 & 0 & 0 & 1842 \\
\hline 3004 & KANSAS & 131 & 21 & 0 & 0 & 102 \\
\hline 3505 & バANSAS & 1.232 & 662 & 0 & 0 & 1894 \\
\hline 3602 & OKILAHOMA & 0 & 106 & 0 & 0 & 106 \\
\hline 3710 & TEXAS & 105 & $8 \%$ & 0 & 0 & 1.90 \\
\hline 3723 & TEXAS & 67 & 6 & 0 & 0 & 73 \\
\hline 3745 & TEXAS & 66 & 0 & 0 & 0 & 66 \\
\hline 3789 & TEXAS & 66 & 0 & 0 & 0 & 66 \\
\hline 7302 & LOUTSTANA GULFF & 132 & 0 & 0 & 0 & 132 \\
\hline 7303 & NO. TEXAS GULF & 674 & 0 & 0 & 0 & 674 \\
\hline 7403 & CALITFOFINTA & 68 & 0 & 0 & 0 & 68 \\
\hline TOTAL & - VOL...UME & 5144 & 2192 & 0 & 0 & 7336 \\
\hline
\end{tabular}

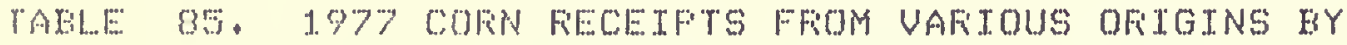
FTEMS IN AFEA 2318 Y KENTUCKY

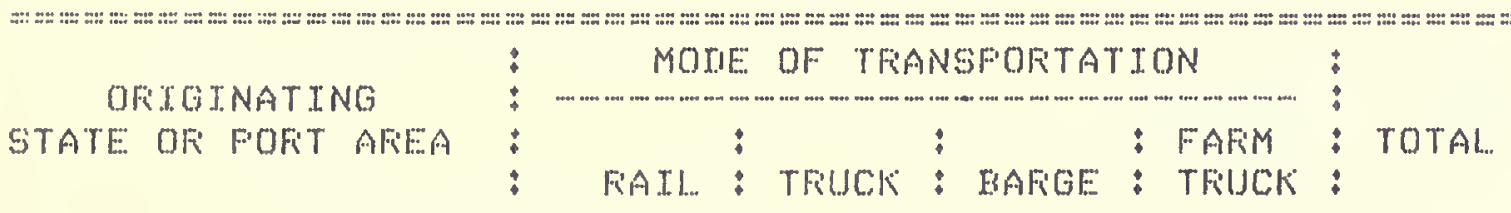

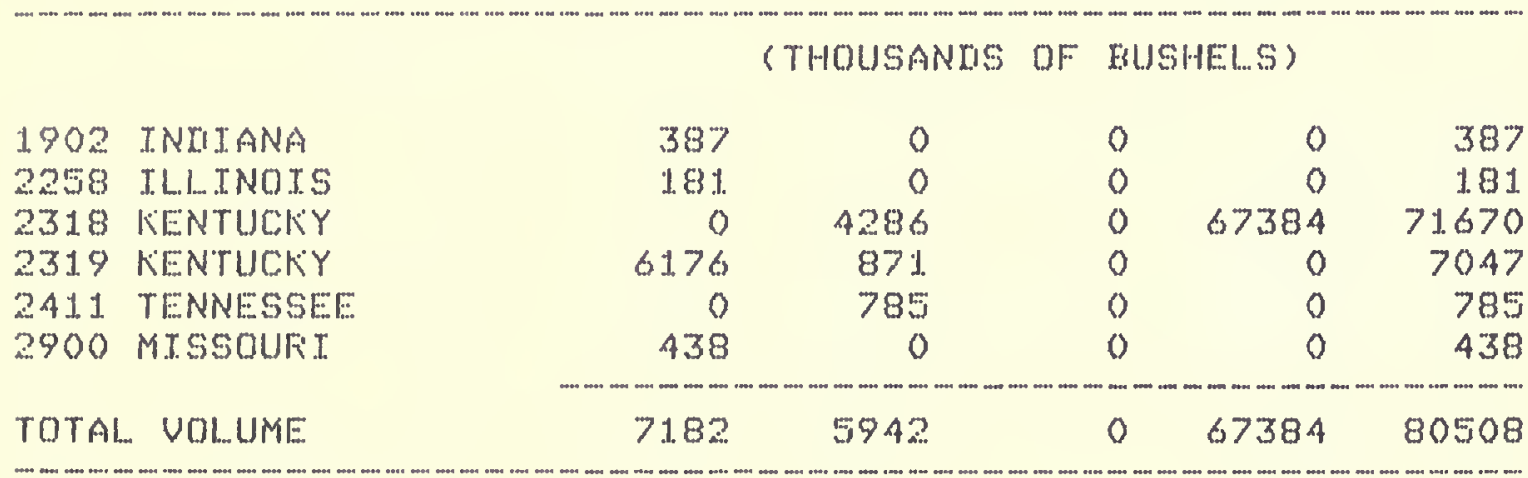


TABIE 66. $19 \%$ CORN SWIFMENTS TO VAFIOUS DESTINATIONS BY FTRS TH AREA ?

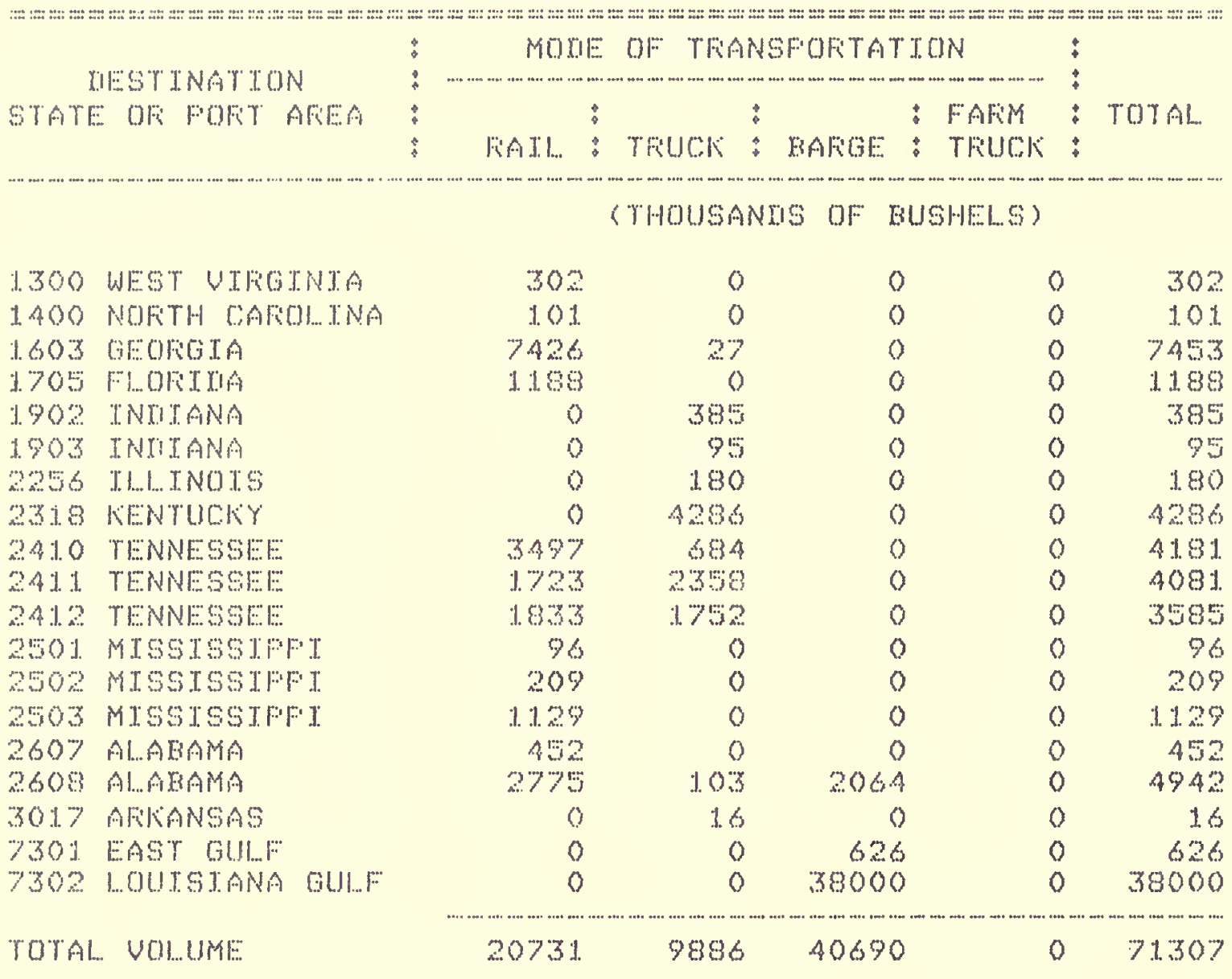

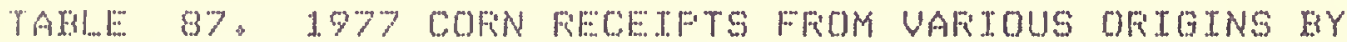
FTFM TN AFEA 2UI\%, KENTUCKY

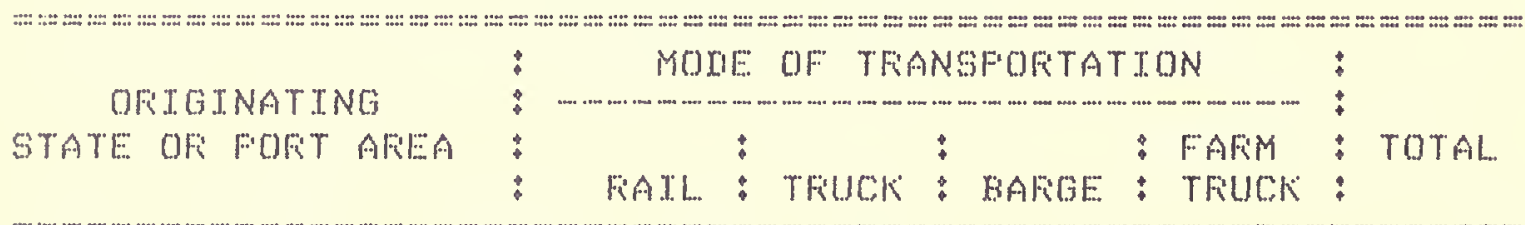

(THOUSANDIS OF RUSHELS)

$\begin{array}{llrrrrr}1825 & \text { OHIO } & 0 & 2256 & 0 & 0 & 2256 \\ 1901 \text { INIIANA } & 50 & 0 & 0 & 0 & 50 \\ 1902 \text { INIIANA } & 1613 & 524 & 0 & 0 & 2137 \\ 1903 \text { INITANA } & 0 & 1800 & 0 & 14000 & 15800 \\ 2258 \text { ILLTNOTS } & 1024 & 0 & 0 & 0 & 1024 \\ 2319 \text { KENTUCKY } & 0 & 420 & 0 & 11303 & 11723 \\ 2320 \text { KENTUCKY } & 0 & 60 & 0 & 0 & 60 \\ \text { TOTAL UOLUME } & 2687 & 5060 & 0 & 25303 & 33050\end{array}$


TAELE 88. 1977 COFN SHIFMENTS TO VAFIOUS LIESTINATIONS BY FIFMS IN AFEA 2319, KEENTUCKYY

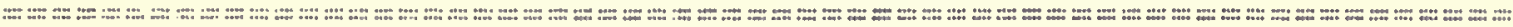

IIESTTNATION

STATE OF FOFT AFEA
MOIE OF TFANSFOFTATION

RAIL: : TFUCK : BAFGE : TFUCK

(THOUSANIS OF BUSHELS)

1200 VIFGINIA

1400 NOFITH CAFIOL. TNA

1500 SOUTH CAFOLI.. INA

1608 GEOFGLA

2318 KENTUCKY

2319 KKENTUCKY

2411. TENNESSEE

2502 MISSISSTFF.

2503 MISSTSSIFFI

2607 ALAEAMA

2608 ALABAMA

2903 MISSOUFI

7301 EAST OUII..F

7302 LOUISIANA GULFF

TOTAL VOLUME:
45

3600

140

374

6176

0

45

0

()

0

62

102

2503

0

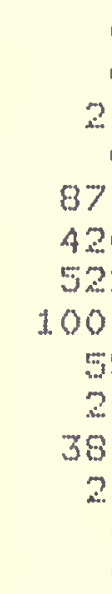

0

0

2.1.

0

371

420

522

1001

5

20

381

26

0

0

3317

\section{0}

0

0

0

0

0

0

0

0

0

0

0

0

5640

130.47

5640

45 3600 1. 61.

374 7047

420

567

1001

55

20

443

128

2) 503

5640

TAELE 99. 1977 COFN FECEIFTS FFOM UAFITUUS OFIGINS EY FTFMS IN AREA 2320, KENTUCKY

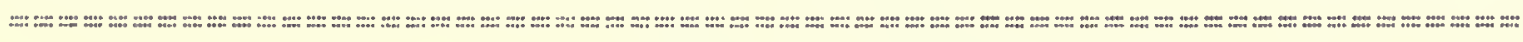

OFTGTNATTNG

STATE OR FOFIT AFEA
MOTE OF TFANSFOFTATION

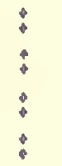

MOII

FAJL: : TFUCK : RAFGE : FAFUM:

TOTAL.

(THOUSANIS OF BUSHEIS)

1825 OHIO

2320 KENTUCKY

TOTAL VOLUME

\begin{tabular}{ccccc}
0 & 302 & 0 & 0 & 302 \\
0 & 0 & 0 & 476 & 476 \\
\hline 0 & 302 & 0 & 476 & 778
\end{tabular}

TAELE 9O. 1977 COFN SHTFMENTS TO VAFIOUS IIESTINATIONS BY FIFIYS IN AFEA 2320, KENTUCKY

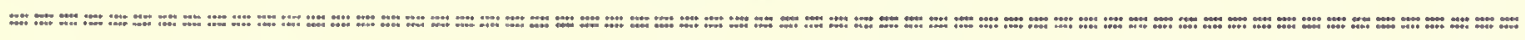

DIESTINATION

STATE OF FOFIT AFEA
MOLE OF" TFAANSFOFITATION

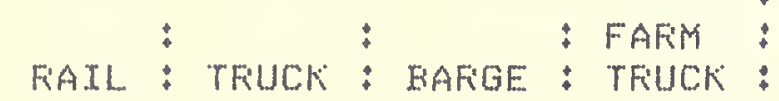

TOTAL

(THOUSANIIS OF BUSHELS)

231. KENTUCKY

TOTAL VOL.UME

\begin{tabular}{ccccc}
0 & 60 & 0 & 0 & 60 \\
\hline 0 & 60 & 0 & 0 & 60
\end{tabular}


TAKHE 91.9979 COFN FECHTS FFOM UARTOUS OFTGINS BY FIFUS INS AREA $3: D O$ Y LOUTSTANA

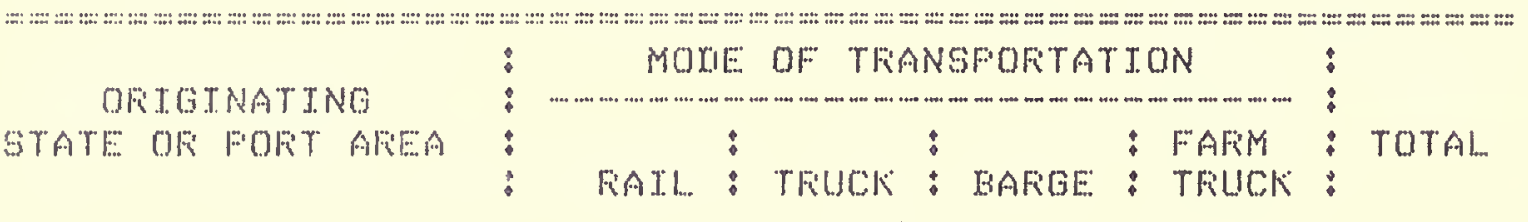

(THOUSANLIS OF KUSHELS)

\begin{tabular}{|c|c|c|c|c|c|c|}
\hline 1603 & GEOFGTA & $1 \% 6$ & 0 & 0 & 0 & 176 \\
\hline 2257 & IILINROTS & 1.900 & 0 & 0 & 0 & 19800 \\
\hline 2258 & TI... INOIS & 228 & 0 & 0 & 0 & 228 \\
\hline 2262 & TILI... JNOJG & 356 & 0 & 0 & 0 & 356 \\
\hline 2270 & TLLINTOIS & 714 & 1492 & 0 & 0 & 2206 \\
\hline 2503 & MTsctsstFl & 0 & 1398 & 0 & 0 & 1398 \\
\hline 2703 & MINNESOTA & 20 & 0 & 0 & 0 & 25 \\
\hline 2801 & TOWA & 1.910 & 0 & 0 & 0 & 1910 \\
\hline 2802 & IOWA & 30 & 0 & 0 & 0 & 30 \\
\hline$\because 900$ & M[SSOUF] & 120 & 0 & 1.356 & 0 & 1476 \\
\hline 3100 & LOUTSTANA & 0 & 2846 & 0 & 0 & 2846 \\
\hline 3404 & NEEBFASKAA & $19 \%$ & 0 & 0 & 0 & 1.97 \\
\hline 3405 & NEERASK゙A & J.27 & 0 & 0 & 0 & 1.27 \\
\hline 3,3003 & KAANSAS & 1247 & 0 & 0 & 0 & 1247 \\
\hline 3505 & KANGAS & 68 & 0 & 0 & 0 & 68 \\
\hline 7302 & LOUTSTANA GULF & 0 & 1.764 & 0 & 0 & 1.764 \\
\hline OTAL. & - VOI..UMIE & 24998 & 7500 & 1356 & 0 & 33854 \\
\hline
\end{tabular}

TABLE 92. 1977 COFN SHTFENTS TO VAFTOUS RESTINATIONS BY FTFMS TN AFEA 3100 Y LOUTSTANA

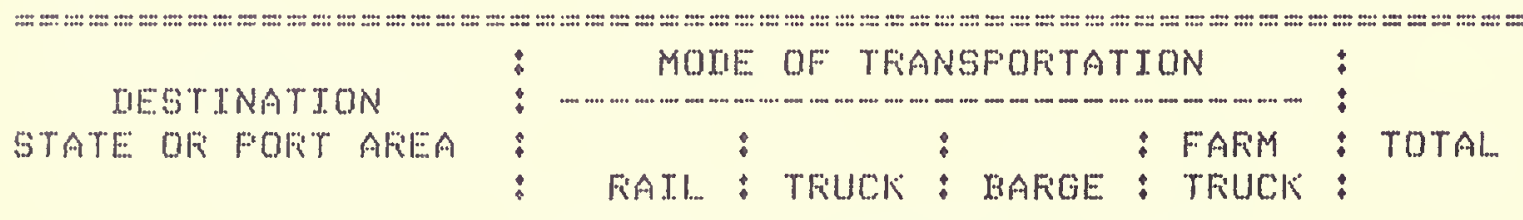

(THOUSANLIS OF RUSHELSS)

\begin{tabular}{llccccr}
2501 MTSSISSIFFI & 0 & 6 & 0 & 0 & 6 \\
3100 LOUISIANA & 0 & 2846 & 0 & 0 & 2846 \\
7302 LOUISIANA GUHF & 0 & 180 & 0 & 0 & 180 \\
TOTAL. UOLUME & 0 & 3032 & 0 & 0 & 3032 \\
\hline
\end{tabular}


TAELE 93. 1979 COFN FECEJFTS FIOM UAFIOUS ORTGTNS BY FJRMS IN AREA 100, MATNE

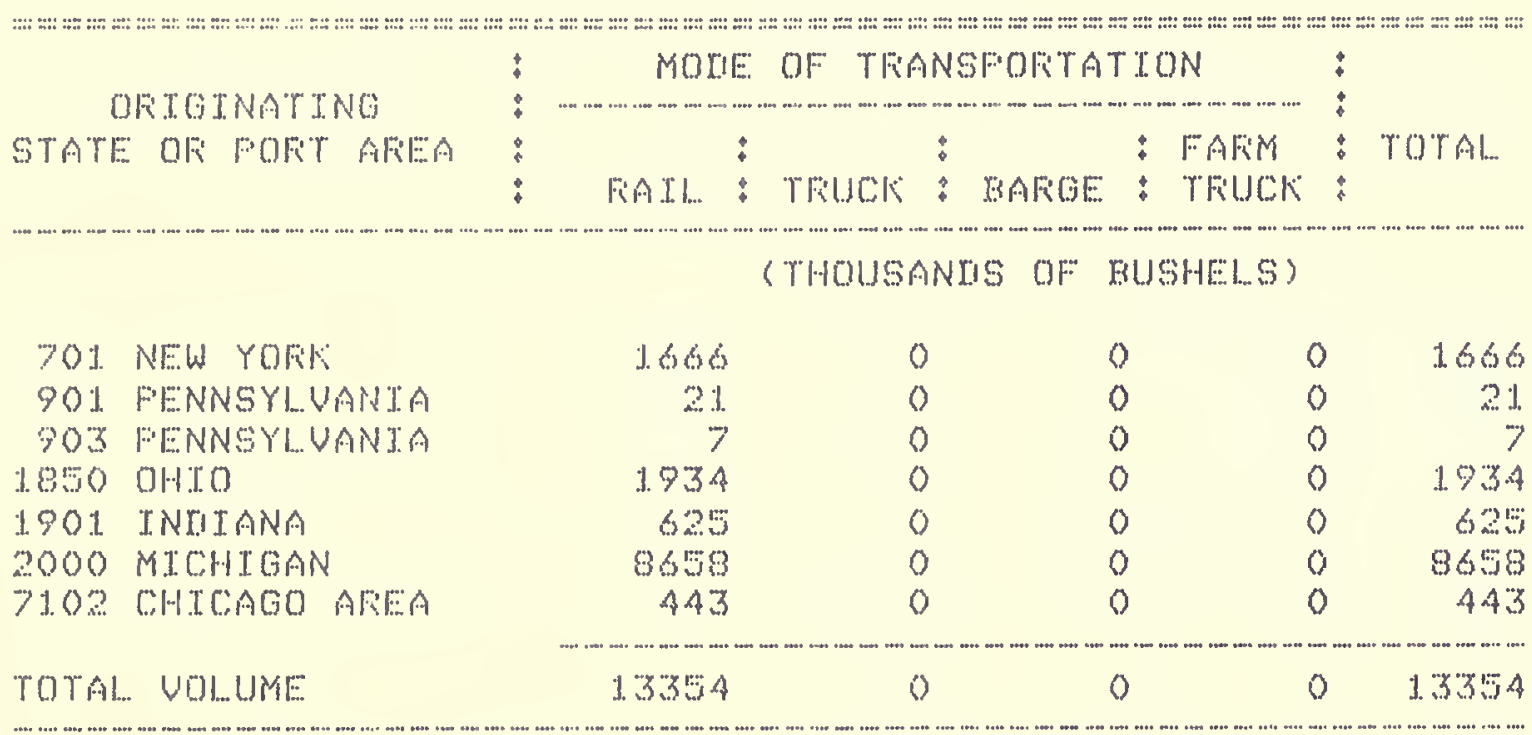

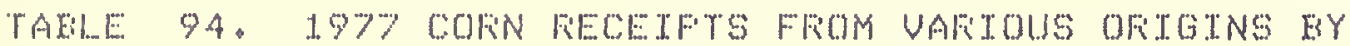
FIFIS IN ARIEA IIIOO Y MALIYI..ANII

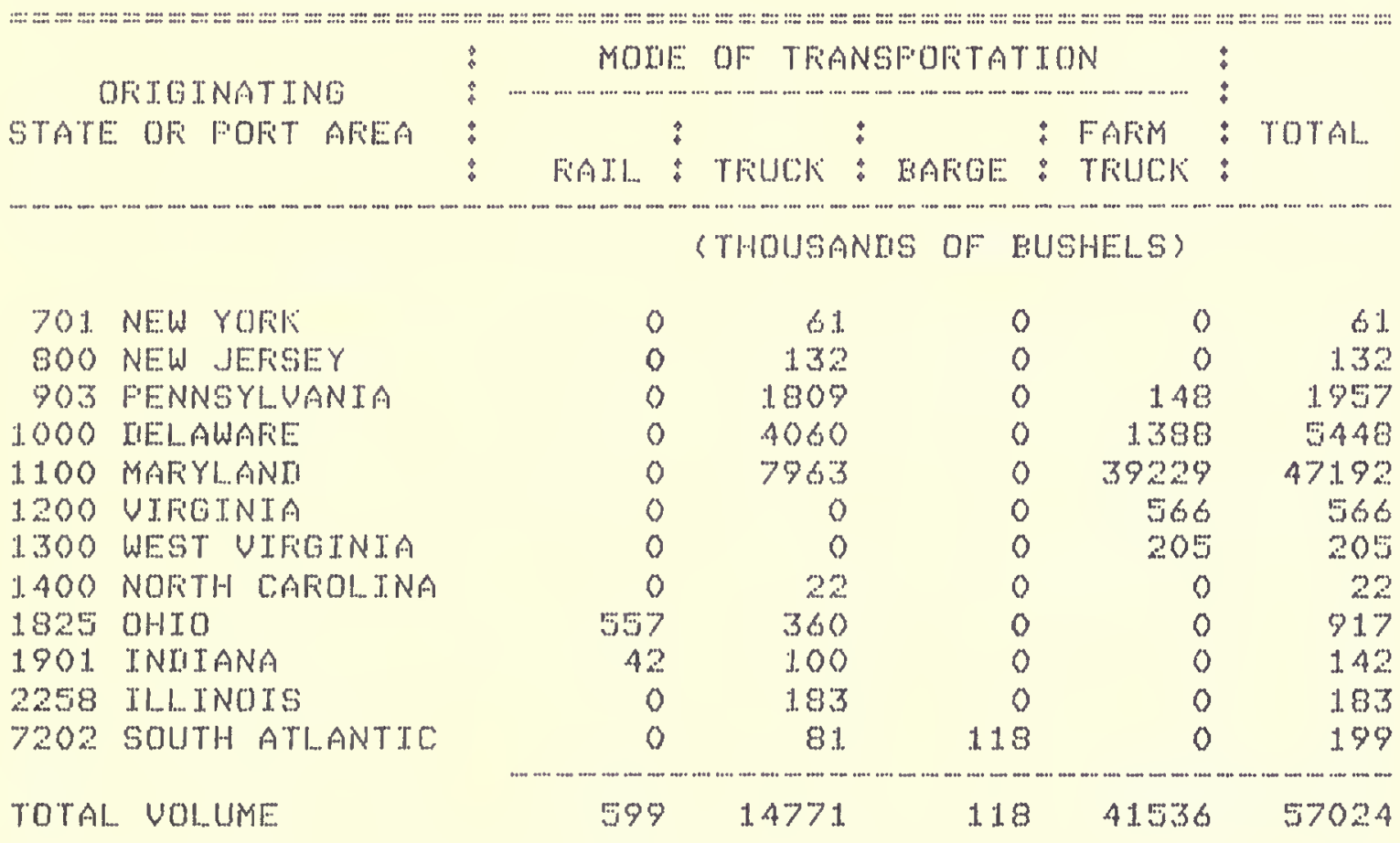


TABLE 9: 1977 CORN SHTFMENTS TO UAFIOUS IIESTINATIONG BY

FTMS IN AFEA IIOO* MAFIYLANI

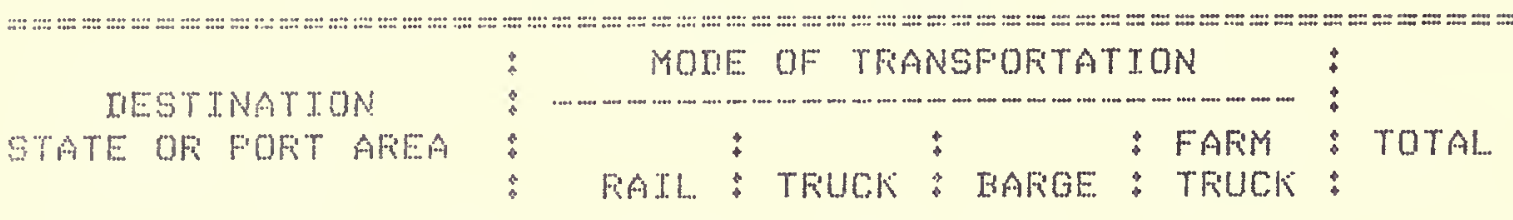

\begin{tabular}{|c|c|c|c|c|c|}
\hline \multirow[b]{2}{*}{ CONNECTTCUT } & \multicolumn{3}{|c|}{ (THOUSANIIS OF } & RUSHELS) & \multirow[b]{2}{*}{1.61} \\
\hline & 161 & 0 & 0 & 0 & \\
\hline 903 FENNSYLUANAA & 0 & 515 & 0 & 0 & 515 \\
\hline 1000 MEEAWAFE & 0 & 6575 & 0 & 0 & 6575 \\
\hline 3.100 MAFYLANII & 0 & 7963 & 0 & 0 & 7963 \\
\hline 1200 VIFGINIA & 0 & 83 & 0 & 0 & 83 \\
\hline 7202 SOUTH ATLANTTC & 0 & 6605 & 71 & 0 & 6676 \\
\hline TOTAL VOLUME & 1.61 & 2174. & 7.1 & 0 & 21973 \\
\hline
\end{tabular}

TABLE 96. $197 \%$ COFN RECETFTS FFOM VARTOUS OFTGINS BY FIFMS IN AREA MOO, MASSACHUSETTS

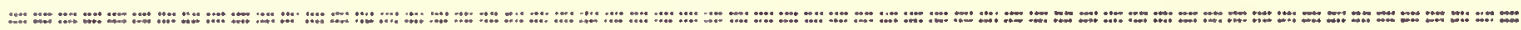

ONTGINATTNG

STATE OF FOFT AREA

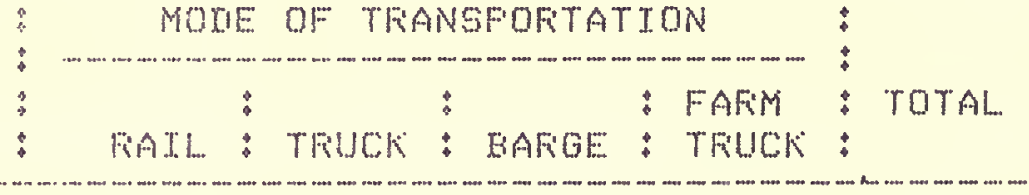

(THOUSANIS OF RUSHELS)
$701 . N E W$ YORK

1.701 JNIITANA

2000 MICHTCAN

TOTAL. VOL..UME

\begin{tabular}{rrrrr}
82 & 0 & 0 & 0 & 82 \\
56 & 0 & 0 & 0 & 56 \\
302 & 0 & 0 & 0 & 302 \\
\hline 440 & 0 & 0 & 0 & 440
\end{tabular}

TAKLE 97. 1977 COFN FECETFTS FFOM UAFIOUS OFIGINS BY FIMS IN AREA 2000 \% MTCHTGAN

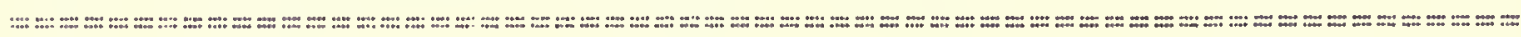

OFTOTNATTNS

STATE OF FOKT AFEA
MOTE OF TFANSFOFTATION

\section{- FAFiM}

:EAREE: FAFUM : TRUK

TOTAL.

\section{2}

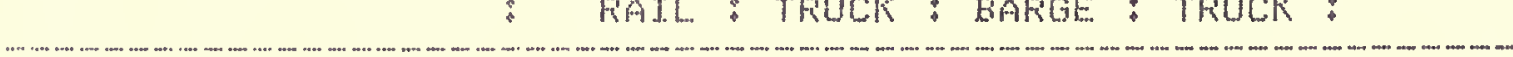

(THOUSANIS OF BUSHELS)

$\begin{array}{llrrrr}1901 \text { INTIANA } & 0 & 6 & 0 & 0 & 6 \\ 2000 \text { MICHIGAN } & 0 & 13869 & 0 & 66756 & 80625 \\ 2702 \text { MINNESOTA } & 0 & 150 & 0 & 0 & 150 \\ \text { TOTAL VOLUME } & 0 & 14025 & 0 & 66756 & 80781\end{array}$


TABLE 98. 1.977 COFN SHIFMENTS TO UAFIOUS RESTINATIONS EY FTFMS TIN AREA 2000 , MICHTGAN

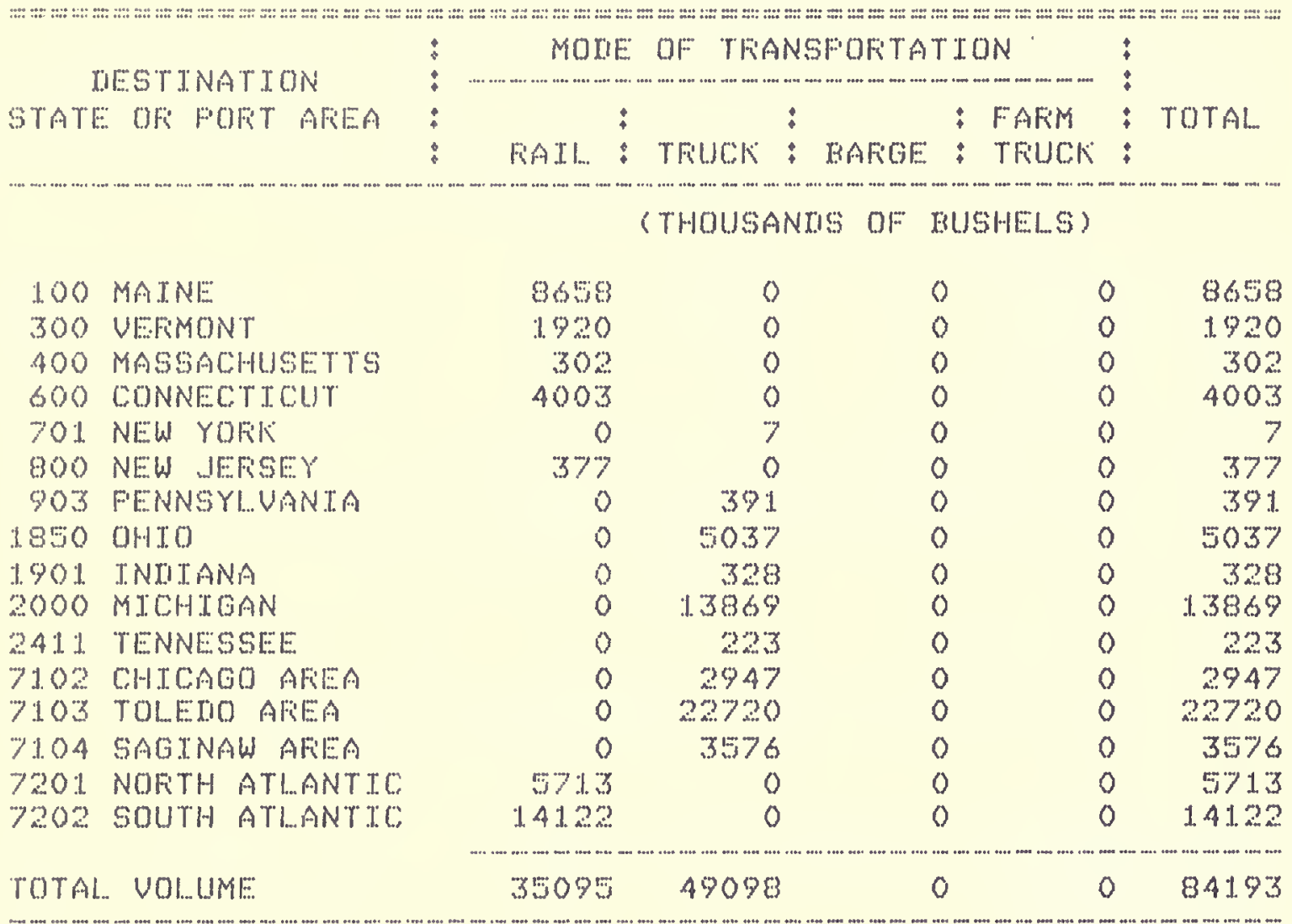

TABHE 99. 1977 COFN FECETFTS FFOM UAFTOUS ORTOINS BY FIFMS TN AFEA 2701, MTNNESOTA

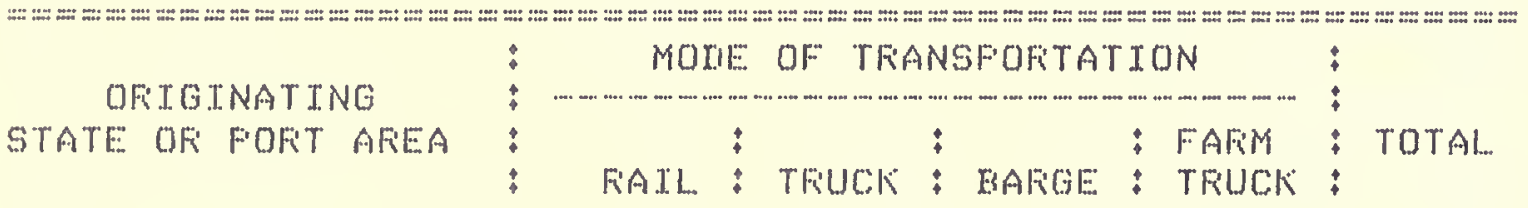

(THOUSANTIS OF BUSHELS)

$\begin{array}{lcccrr}2701 \text { MINNESOTA } & 0 & 184 & 0 & 191 & 375 \\ 2703 \text { MINNESOTA } & 0 & 1684 & 0 & 0 & 1684 \\ 2704 \text { MINNESOTA } & 409 & 40 & 0 & 0 & 449 \\ 3200 \text { NORTH MAKOTA } & 0 & 20 & 0 & 0 & 20 \\ \text { TOTAL VOLUME } & 409 & 1928 & 0 & 191 & 2528\end{array}$




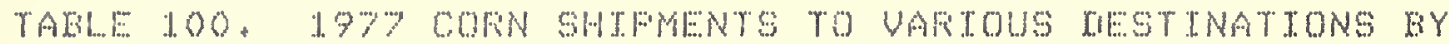
FTEMS TN AREA ?\%OI MTNNESOTA

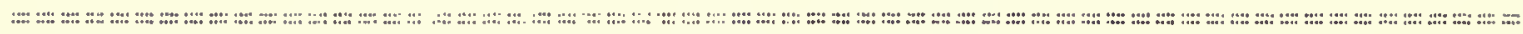

IESTTNATTON

STATE: OK FOKT ANEA
MORE: OF TRABSFORTATTON

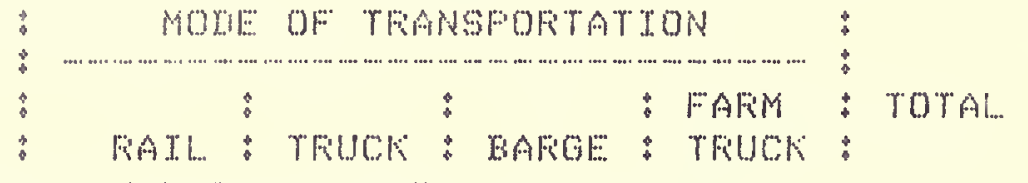

(THOUSANDS OH: BUSHE: (...s)
2701 MINNESOTH

TOTAL.. VOLUME:

$\begin{array}{ccccc}0 & 184 & 0 & 1 & 1815 \\ 0 & 184 & 0 & 1 & 185\end{array}$

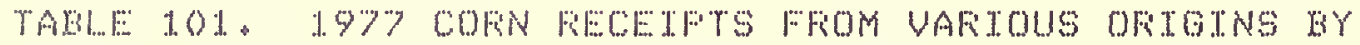
FTHS TN ANEA 2702 y MNNFEOTA

:

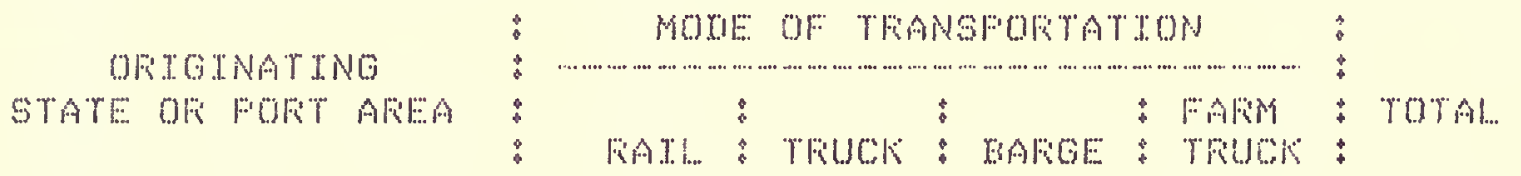

(THOUSANCS OF BUSHISS)

270 I. MTNNESOTA

2702 MTNNESOTA

2703 MINNESOTA

$2 \% 04$ MTNNESOTA

$270 \%$ MUNNESOTA

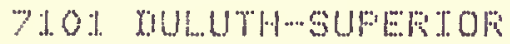

TOYALI.. VOL..UMI::

$\begin{array}{rr}0 & 0 \\ 0 & 2170 \\ 0 & 1.91 \\ 0 & 960 \\ 9 & 1669 \\ 4 & 6\end{array}$

(1) $1 \%$

0) 3743

$0 \quad 0$

0

0

$0 \quad 0$

375
12

$591 \%$

$19 \%$

960

1. 678

10

$1304986 \quad 0 \quad 375 \% \quad 8764$

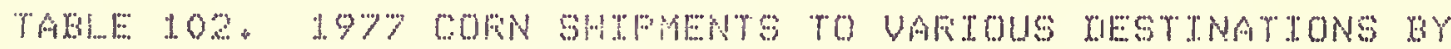

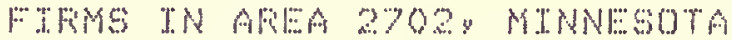

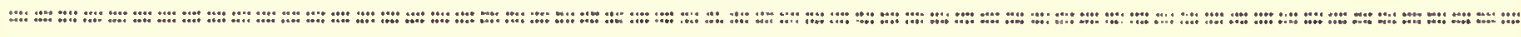

DESTTNATTON

STATE OF FOFT AFEA

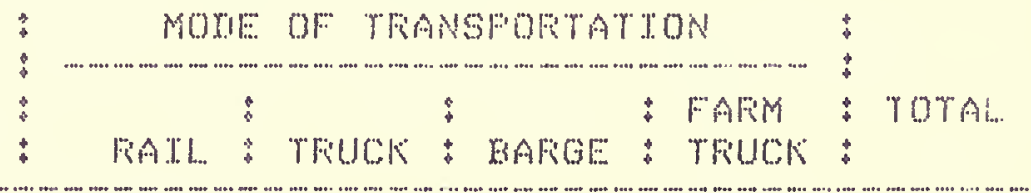

(THOUSANCIS OF RUSHELS)

\section{MICHIGAN \\ 21.01. WISCONSIN \\ 2702 MTNNESOTA \\ 2705 MINNESOTA \\ 9000 EXFOFT}

TOYAL VOLUME

$\begin{array}{rrrrr}0 & 150 & 0 & 10 & 160 \\ 0 & 1277 & 0 & 70 & 1347 \\ 0 & 2170 & 0 & 1393 & 3563 \\ 23 & 793 & 0 & 0 & 1016 \\ 0 & 29 & 0 & 0 & 29 \\ 23 & 4419 & 0 & 1473 & 6115\end{array}$


TABLE 103. 1977 COFN FECEIFTS FFOM VAFIOUS OFTGTNS BY FIFMS IN AFEA 2703, MTNESOTA

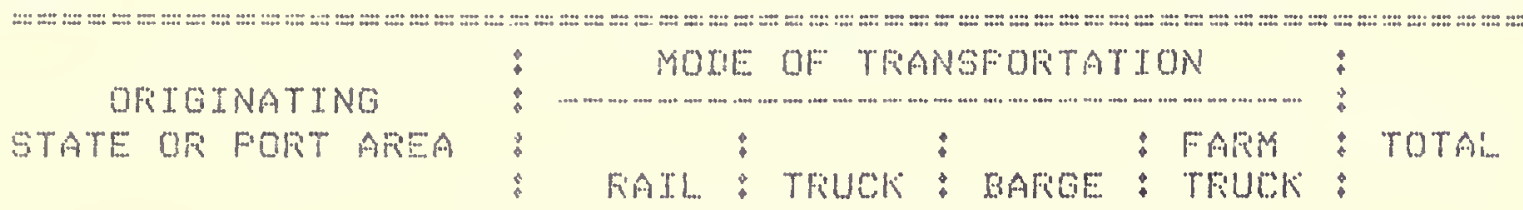

(THOUSANDS OF BUSHELS)

$\begin{array}{lrrrrr}2703 \text { MINNESOTA } & 62 & 12760 & 0 & 67563 & 30385 \\ 2704 \text { MINNESOTA } & 0 & 4910 & 0 & 276 & 0186 \\ 2705 \text { MINNESOTA } & 0 & 0 & 0 & 1196 & 1196 \\ 3301 \text { SOUTH MAKOTA } & 0 & 1872 & 0 & 300 & 2172 \\ \text { TOYAL VOLUME } & 62 & 19542 & 0 & 69335 & 89939\end{array}$

TABLE 104. 1977 COFN SHTFENTS TO VARTOUS LESTENATIONS BY FIFIMS TN AREA 2703 Y MINNESOTA

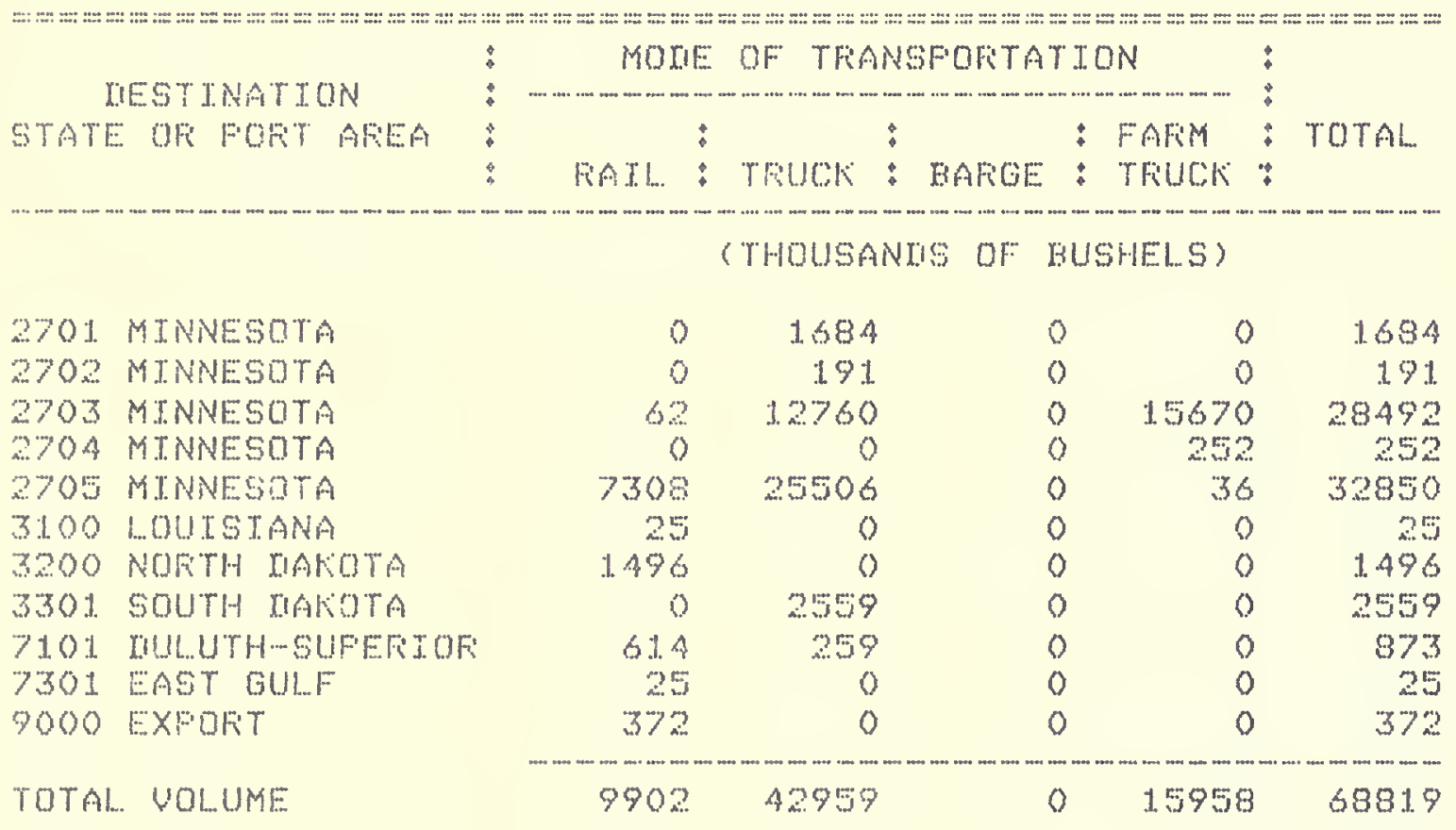




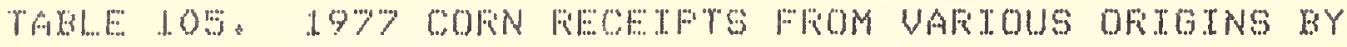
FTIMS TN AVIEA 2704 Y MTNNESOTA

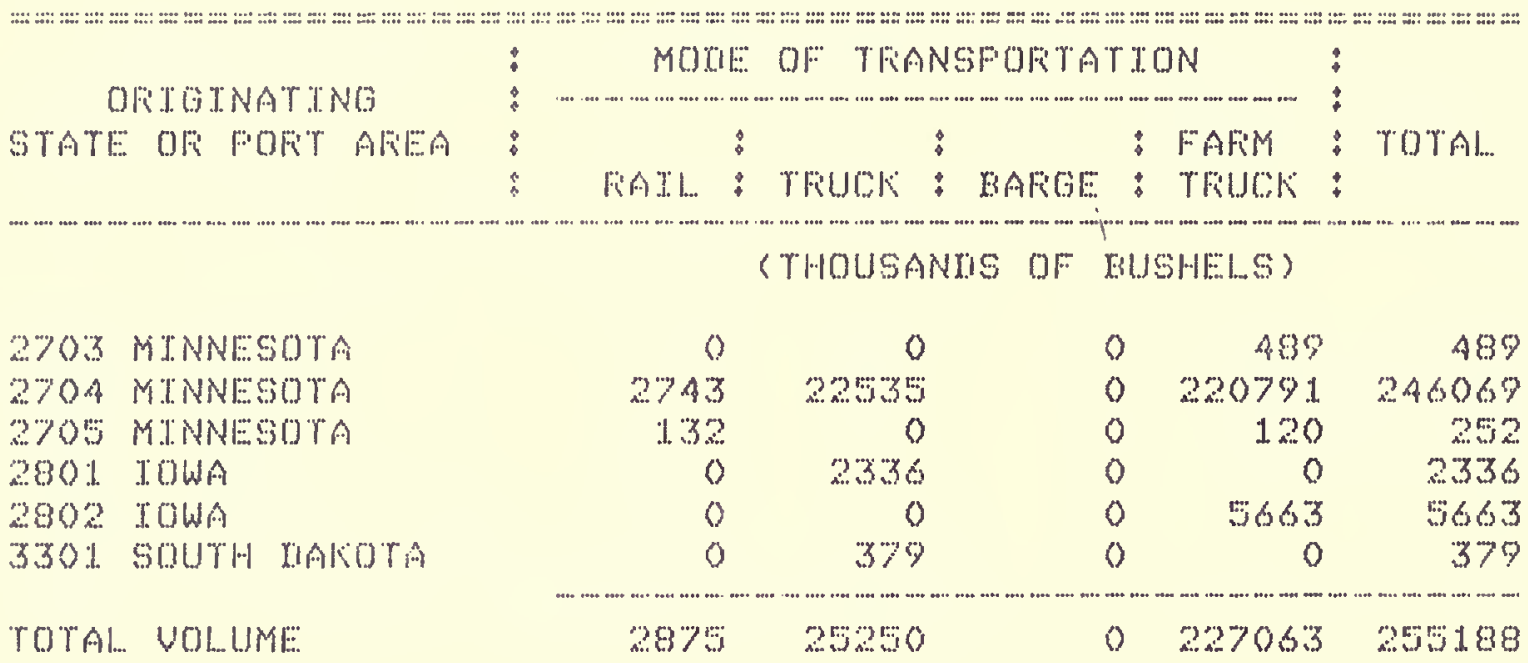

TALLE 106,1977 COFIN SHIFMENTS TO UAFTOUS IESTINATIONS EY FTEMS TN AFEA 2TOAY MTNNESOTA

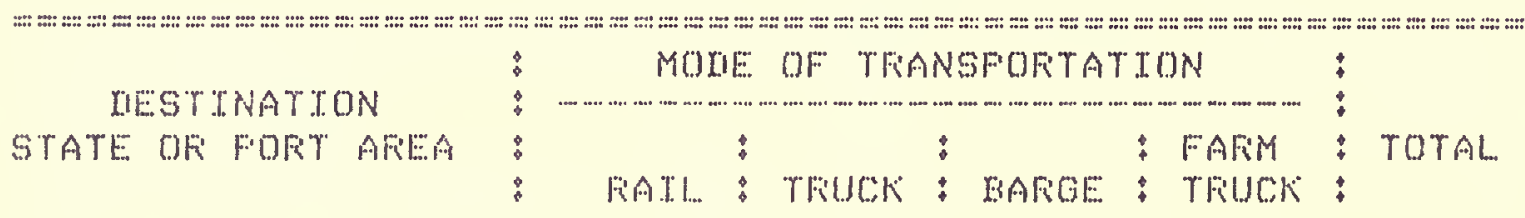

2101 WTSOONSIN

2701 MINNESOTA

2702 MTNNESOTA

2703 MTNNESOTA

2704 MINNESOTA

2705 MTNNESOTA

2801 IOWA

2802 T.OWA

2803 IIOWA

3200 NOFITH MIAKOTA

3301 . SOUTH IIAKOOTA

4600 OFEEON

7101 IUUUTH SUFERIOR

Y102 CHTCAOO AFEA

7302 LOUISIANA GULF

7303 NO. TEXAS GUL..F

9000 EXFOFT

TOTAL VOL..UME:
(THOUSANLS OF BUSHEI...S?

\begin{tabular}{|c|c|c|c|c|}
\hline 0 & 416 & 0 & 204 & 620 \\
\hline $40 \%$ & 40 & 0 & 0 & 449 \\
\hline 0 & 960 & 0 & 0 & 960 \\
\hline 0 & 4910 & 0 & $16 \mathrm{~s} 1$ & 6561 \\
\hline 2743 & 22035 & 0 & 16313 & 41591 \\
\hline 21646 & 69265 & 0 & 0 & 86911 \\
\hline 52 & 359 & 0 & 0 & 41. 1 \\
\hline 0 & 12 & 0 & 84 & 96 \\
\hline 0 & $10 \%$ & 0 & 0 & $10 \%$ \\
\hline 0 & 11.00 & 0 & 0 & 1100 \\
\hline 0 & 2143 & 0 & 0 & 2143 \\
\hline 1.600 & 0 & 0 & 0 & 1600 \\
\hline 3664 & 333 & 0 & 0 & 3997 \\
\hline $10 \%$ & 0 & 0 & 0 & $10 \%$ \\
\hline 22772 & 0 & 0 & 0 & 20772 \\
\hline 2024 & 0 & 0 & 0 & 2024 \\
\hline 733 & 200 & 0 & 0 & 9.3 .3 \\
\hline 5075 & 98380 & 0 & 18252 & 1723837 \\
\hline
\end{tabular}


TABLE 107. 1977 COFN RECEIFTS FROM WAFTOUS ORTEINS BY

FIRMS IN AFEA 2705 , MINNESOTA

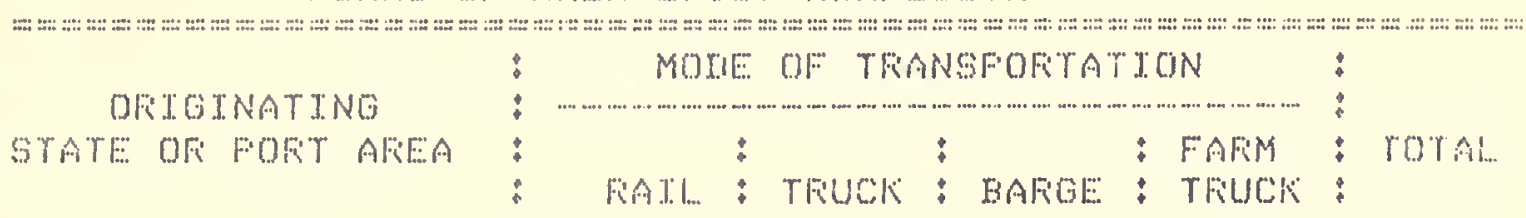

(THOUSANRS OF RUSHELE)

2101 WISCONGIN

2102 WISCONGIN

2103 WISCONSTN

2702 MTNEESOTA

2703 MINNESOTA

2704 MINNESOTA

2705 MINNESOTA

2801 IOWA

2802 IOWA

2803 IOWA

3200 NOFTH MAKOTA

3301 SOUTH IIAKOTA

3405 NEEFASKA

$\begin{array}{rr}0 & 4542 \\ 0 & 474 \\ 223 & 786 \\ 223 & 793 \\ 7308 & 20606 \\ 21.46 & 65260 \\ 891 & 42699 \\ 0 & 128 \\ 11 & 6968 \\ 0 & 530 \\ 175 & 60 \\ 497 & 634 \\ 206 & 47\end{array}$

0
0
0
0
0
0
0
0
0
0
0
0

4962

47.8

1.009

1022

34585

87874

96227

128

7022

620

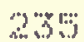

1. 121

253

TOTAL. VOL.IMME

$31170 \quad 14932 ?$

() 55620

235112

TAELE 108. 1977 COFN SHTFENTS TO UAREOUS DESTINATTONS EY FTFMS IN AFEA 27OG MINNESOTA

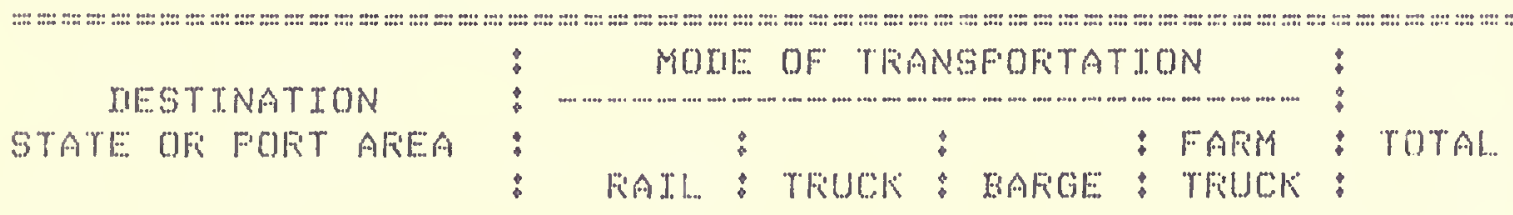

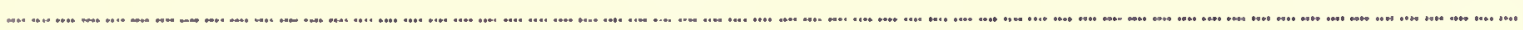

(THOUSANISS OF BUSHELS)

\begin{tabular}{|c|c|c|c|c|c|c|}
\hline 2101 & WTSCONSIN & 0 & 1.777 & 0 & 12 & 1789 \\
\hline 2102 & WISCONSTN & 0 & 4400 & 0 & 0 & 4400 \\
\hline 2103 & WISCONSIN & & & & & 2363 \\
\hline 2410 & TENNESSEE & COMEIN & II TO AVO. & II DI ISCLE & DSURE & 549 \\
\hline 2608 & ALAEAMA & 0 & 0 & 430 & 0 & 430 \\
\hline 2702 & MTNNESOTA & 9 & 1.669 & 0 & 0 & 1678 \\
\hline 2704 & MINNESOTA & 132 & 0 & 0 & 0 & 132 \\
\hline 2705 & MINNESOTA & 891 & 42589 & 0 & 2844 & 46324 \\
\hline 2803 & IOWA & 179 & 0 & 0 & 0 & 179 \\
\hline 3301 & SOUTH RIAKKOTA & 208 & 0 & 0 & 0 & 208 \\
\hline 3745 & TEXAS & 1232 & 0 & 0 & 0 & 1232 \\
\hline 4600 & OREGON & 2366 & 0 & 0 & 0 & 2366 \\
\hline 7101 & TULUTHW-SUFEETOEF & 4 & 29 & 0 & 0 & 33 \\
\hline 7102 & CHICAGO AFEA & 96 & 0 & 0 & 0 & 96 \\
\hline 7104 & SAGINAW AREA & 1.9 & 0 & 0 & 0 & 19 \\
\hline 7301 & EAST GULFF & 0 & 0 & 196 & 0 & 196 \\
\hline 7302 & LOUISIANA GULFF & 687 & 0 & 75398 & 0 & 76085 \\
\hline 9000 & EXFORT & 1.334 & 0 & 0 & 0 & 1.334 \\
\hline ITAL. & DLL..UME & 731.4 & 52670 & 76573 & 2856 & 1.3941 \\
\hline
\end{tabular}


TABHE 109. $197 \%$ COFN RECETFTS FFOM UAFIOUS OFIGINS BY

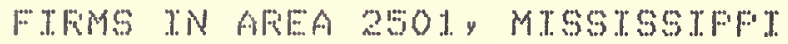

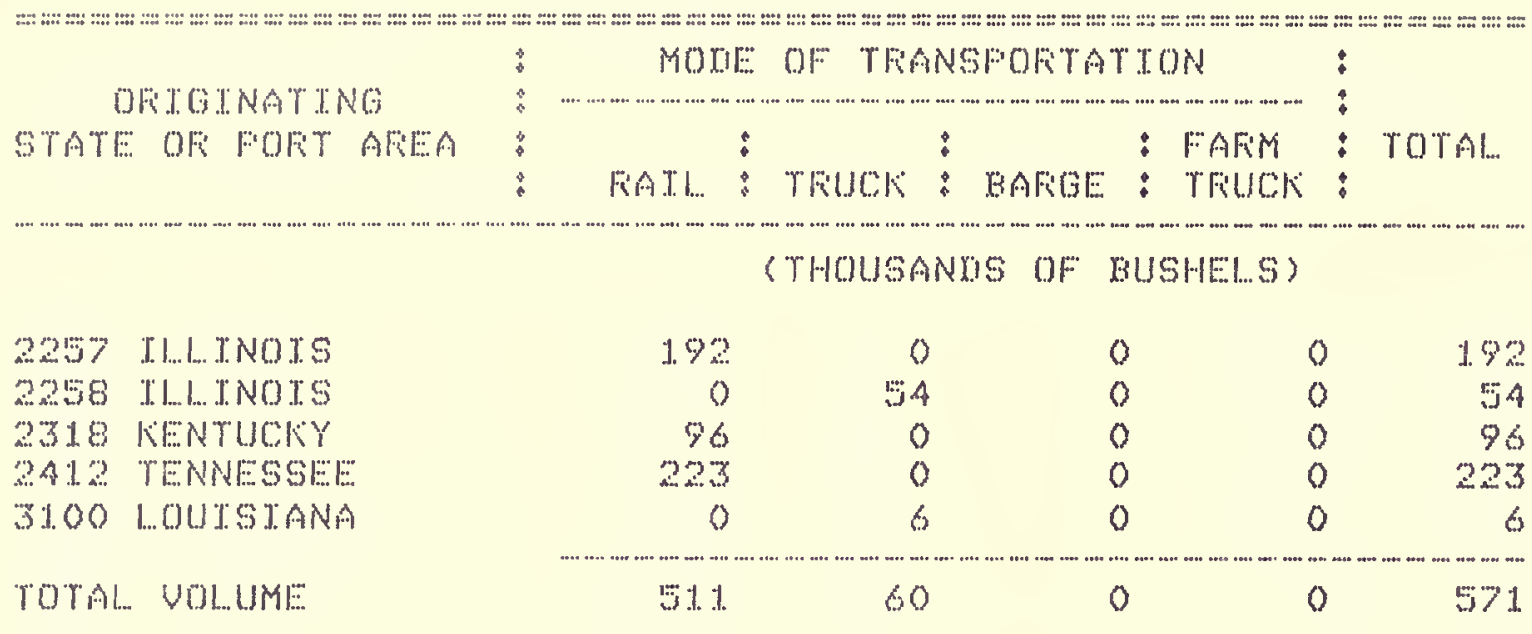

TABLE 110. 197\% COFN FECETFTS FEOM WAFTOUS OFICTNS BY

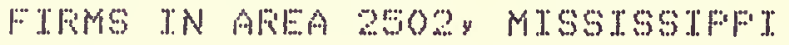

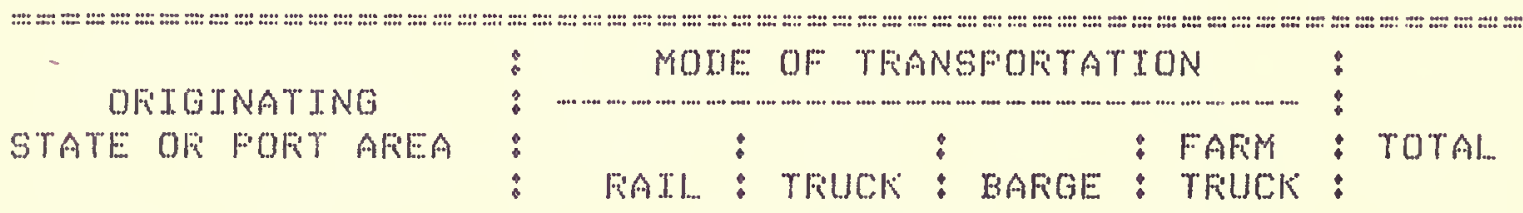

\begin{tabular}{|c|c|c|c|c|c|c|}
\hline \multirow[b]{2}{*}{1825} & \multirow[b]{2}{*}{ 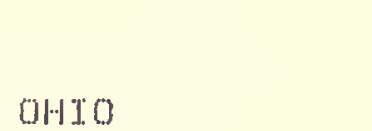 } & \multicolumn{3}{|c|}{ STHOUSANDS OF } & BUSHEI:...S3 & \multirow[b]{2}{*}{108} \\
\hline & & 11. & 97 & 0 & 0 & \\
\hline 1901 & INDIANA & 959 & 487 & 0 & 0 & 1446 \\
\hline 2057 & ILI.. INOTS & 21. & 0 & 0 & 0 & 21 \\
\hline 2258 & ILLINOJS & 576 & 1.89 & 0 & 0 & 765 \\
\hline 2262 & ILITNOTS & 650 & 0 & 0 & 0 & 650 \\
\hline 2270 & T.LITNOTS & 1.7 & 0 & 0 & 0 & 17 \\
\hline 2318 & K゙ENTUCKY & 209 & 0 & 0 & 0 & 209 \\
\hline 231.9 & KENTUCKY & 0 & 1001 & 0 & 0 & 1001 \\
\hline$\therefore 412$ & TENNESSEE & 454 & 0 & 0 & 0 & 454 \\
\hline 2502 & MISSISSIFFI & 0 & 52 & 0 & 413 & 465 \\
\hline 2503 & MISSJSSIFFT & 99 & 0 & 0 & 0 & 99 \\
\hline 2803 & J.OWA & 406 & 588 & 0 & 0 & 5894 \\
\hline 2903 & MTSSOUF]. & 2516 & 0 & 0 & 0 & 2516 \\
\hline 3505 & KIANSAS & 68 & 0 & 0 & 0 & 68 \\
\hline 3711 & TEXAS & 68 & 0 & 0 & 0 & 68 \\
\hline 7302 & LOUTGIANA GULF & 624 & 0 & 0 & 0 & 624 \\
\hline TOTAL & VOLUME & 6678 & 7314 & 0 & 413 & 14405 \\
\hline
\end{tabular}


TABLE 11. 1.977 COHN SHTFMENTS TO UARTOLS DESTTNATTONG DY FIFMS IN AREA 2EOZY MISSISSTFFI

\begin{tabular}{|c|c|c|c|c|c|c|c|c|}
\hline MESTINATION & $\vdots$ & \multicolumn{2}{|c|}{ MOTIE OF TR } & ANSFOFIA & T. I. & IN & \multirow{3}{*}{$\vdots$} & \multirow{3}{*}{ TOYAL. } \\
\hline STATE OF FOFT AREA & : & & $:$ & : & & FAFIM & & \\
\hline & $:$ & FATL. & 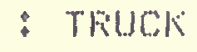 & : $\mathrm{BAFOE}$ & : & TFUCK゙ & & \\
\hline & & \multicolumn{3}{|c|}{ CTWOUSANTS OF } & \multicolumn{2}{|c|}{ BUSHEI...S) } & & \\
\hline 2412 TENNESSEE & & 0 & 1.3 & & 0 & & 0 & 1.34 \\
\hline 2502 MTSSISSIFFI & & 0 & 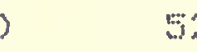 & & 0 & & 0 & 52 \\
\hline 2608 ALAFAMA & & & 4 & & 0 & & 0 & 40 \\
\hline TOYAL.. VOL..UME & & 0 & 22 & & 0 & & 0 & 226 \\
\hline
\end{tabular}

TAELE I12。 1977 COFN RECFTFTS FROM UAFTOUS OFTOINS BY

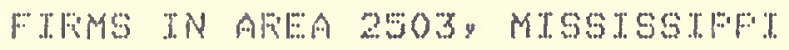

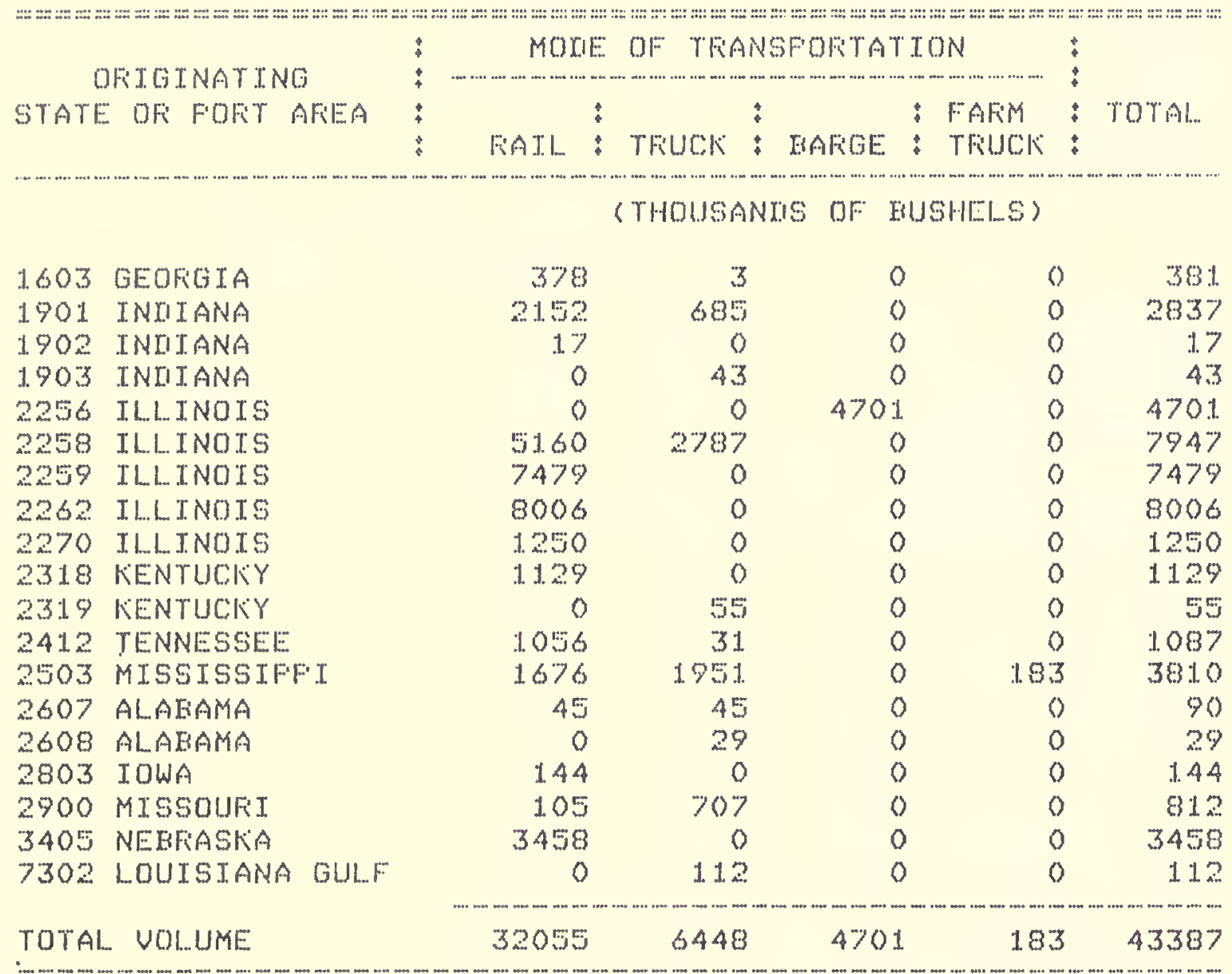


TAELE 113. 1977 COFN SHIFMENTS TO VARTOUS DESTINATIONS BY FIFMS IN AREA 2503, MISSISSIFFI

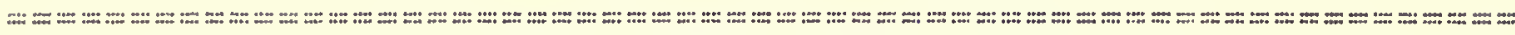

IIESTTINATION

STATE OF FOFT AFEA

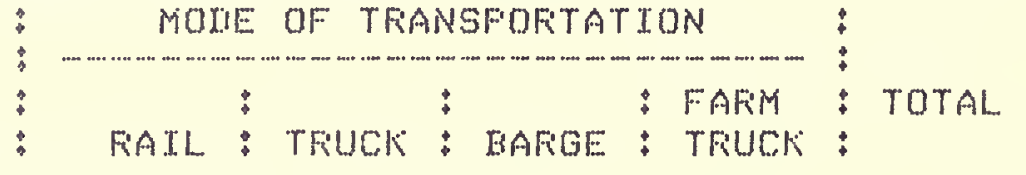

(THOUSANDS OF BUSHELS)

2502 MTSSTSSTFFT

303 MISSTSSIFFI

3100 LOUISIANA

7301 EAST GULF

TOTAL VOI...UME

\begin{tabular}{rrrrr}
98 & 0 & 0 & 0 & 99 \\
1676 & 1951 & 0 & 497 & 4124 \\
0 & 1398 & 0 & 0 & 1398 \\
0 & 216 & 0 & 0 & 216 \\
\hline 1775 & 3565 & 0 & 497 & 5837
\end{tabular}

TAELE 11.4. 1977 COFN FECETFTS FFOM UAFIOUS ORTGINS BY FIFMS IN AFEA 2900. MISSOUFI

\begin{tabular}{|c|c|c|c|c|c|c|c|c|}
\hline OFIOINAT TNG & : & \multicolumn{5}{|c|}{ MOLE OF TRANSFORTATION } & \multirow{3}{*}{$\begin{array}{l}\vdots \\
\vdots \\
\vdots\end{array}$} & \multirow{3}{*}{ TOTAL } \\
\hline STATE OF FOKT AFEA & $:$ & & $\$$ & : & : & FAFM & & \\
\hline & : & RATIL. & TFUUKK & : BAFIGE & : & TRUCK & & \\
\hline & & \multicolumn{3}{|c|}{ (THOUSANIIS OF } & \multicolumn{3}{|c|}{ EUSHELS) } & \\
\hline 2801 TOWA & & 340 & 27 & & 0 & 0 & & 611 \\
\hline 2802 IOWA & & 12 & 2347 & & 0 & 0 & & 2359 \\
\hline 2900 MISSOUFI & & 12767 & 3643 & & 0 & 63105 & & 112303 \\
\hline NORTH IIAKOTA & & 527 & ( & & 0 & 0 & & 527 \\
\hline TOTAL.. VOLUME & & 13646 & 39045 & & 0 & 63105 & & 115800 \\
\hline
\end{tabular}


TAELE 1.15. 1977 CORN SHIFMENTS TO VAFIOUS IESTINATIONS EY FIFMS IN AREA 2900, MJSSOUFI

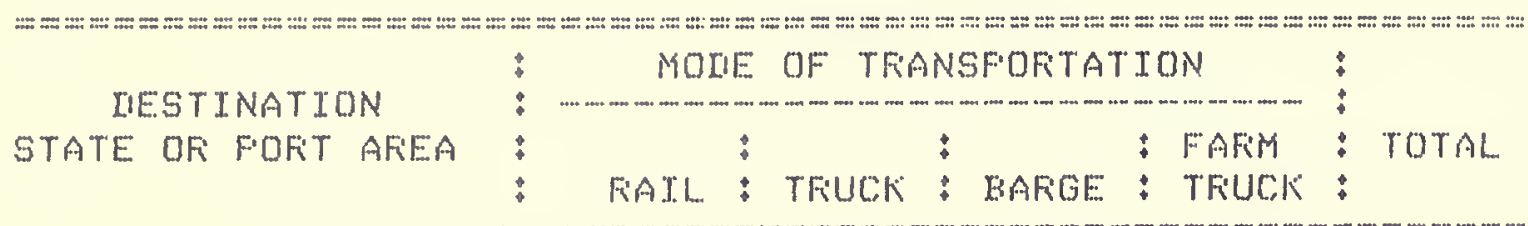

\begin{tabular}{|c|c|c|c|c|c|c|}
\hline \multirow[b]{2}{*}{2318} & \multirow[b]{2}{*}{ KEENTUCKY } & \multicolumn{5}{|c|}{ (THOUSANDS OF BUSHELS) } \\
\hline & & 438 & 0 & 0 & 0 & 438 \\
\hline 2410 & TENNESSEE & 372 & 0 & 0 & 0 & 372 \\
\hline 2503 & MISSTSSTFFT. & 1.05 & 707 & 0 & 0 & 812 \\
\hline 2608 & ALABAMA & 0 & 0 & 1350 & 0 & 1.350 \\
\hline 2900 & MISSOURI & 1. 2767 & 36431 & 0 & 0 & 49198 \\
\hline 3100 & LOUJSIANA & 120 & 0 & 1.356 & 0 & 1.476 \\
\hline 3604 & OKLAHOMA & 524 & 156 & 0 & 0 & 680 \\
\hline 3723 & TEXAS & 2568 & 0 & 0 & 0 & 2568 \\
\hline 3745 & TEXAS & 312 & 0 & 0 & 0 & 312 \\
\hline 3789 & TEXAS & 10 & 0 & 0 & 0 & 10 \\
\hline 4100 & NEW MEXICO & 636 & 0 & 0 & 0 & 636 \\
\hline 4704 & CALIFOFINIA & 245 & 0 & 0 & 0 & 245 \\
\hline 7301 & EAST GULF & 0 & 0 & 1.000 & 0 & 1000 \\
\hline 7302 & LOUISIANA GULF & 15 & 0 & 27450 & 0 & 27503 \\
\hline 7303 & NO. TEXAS GULF & 2046 & 0 & 0 & 0 & 2046 \\
\hline TOTAL & - VOLLUME: & 20196 & 37284 & 31156 & 0 & 88646 \\
\hline
\end{tabular}

TABLE 116. 1977 COFN FECEIFTS FFOM UAFIOUS OFIGINS EY FTHMS ITN AFEA 2901, MJSSOUFI

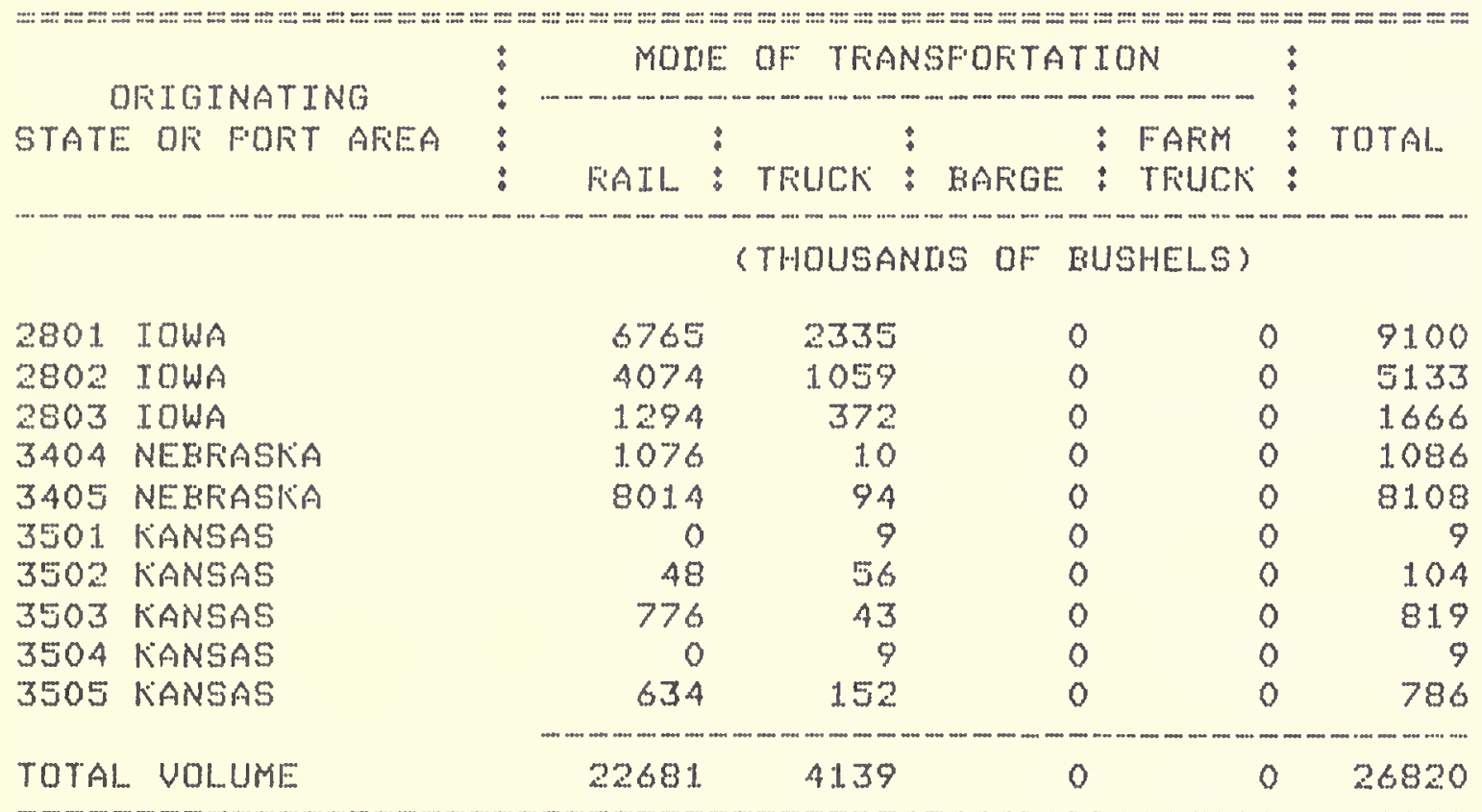


TABLE 1.7. $197 \%$ COFN SHTWMENTS TO VARTDUS DESTINATIONS EY FTFMS IN AFEA 290 I. MISSOUFI

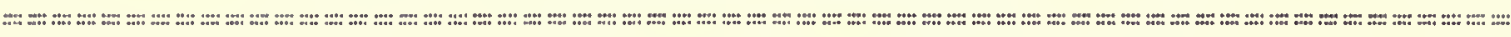

IIESTMATTON

GTATE OFI FORT AFEA
MOXE OF TFANSFOFTATION

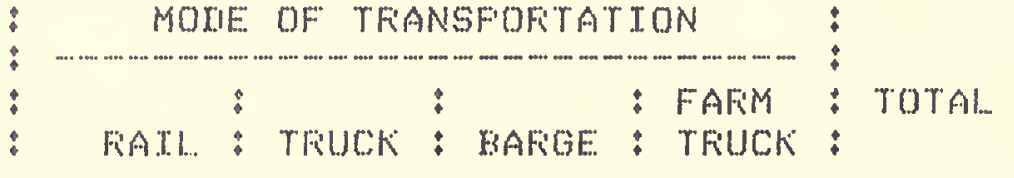

(THOUSANIS OF EUSHELS)

\begin{tabular}{|c|c|c|c|c|c|}
\hline $226 \pm$ IILINOIS & 0 & 1.910 & 0 & 0 & 1910 \\
\hline $226 \%$ TLLTNOIS & 0 & 2.11 & 0 & 0 & 211 \\
\hline 2270 JLLINOTOS & 43 & 0 & 0 & 0 & 43 \\
\hline 3016 AFKKANSAS & 6110 & 0 & 0 & 0 & 6110 \\
\hline 3017 AFKKANSAS & 4367 & 0 & 0 & 0 & 4367 \\
\hline 3038 AFKIANSAS & 212 & 0 & 0 & 0 & 212 \\
\hline 340S NEBFIASKRA & 0 & 60 & 0 & 0 & 60 \\
\hline 303 KIANSAS & 3036 & 2527 & 0 & 0 & 5563 \\
\hline 3005 KANSAS & 41 & 10 & 0 & 0 & 51 \\
\hline OTAL VOI.. UME & 13809 & 4718 & 0 & 0 & 18527 \\
\hline
\end{tabular}

TAELE LIE, I97\% COKN FECEIFTS FFOM UAFTOUS OFIGINS EY FIFMS TM AFEA 2902 Y MISSOUFT.

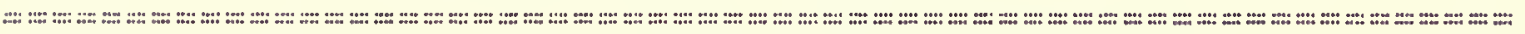

DFICINATING

STATE OF PORT AREA
MOYE OF TFANSFOFITATION

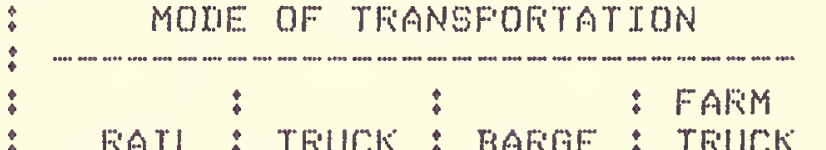

:

toral.

\section{(THOUSANDS OF BUSHELS)}

2803 IOWA

TOTAL VOLUME

$\begin{array}{ccccc}0 & 392 & 0 & 0 & 392 \\ 0 & 392 & 0 & 0 & 392\end{array}$

TABLE 119. 1977 COFN SHIFMENTS TO WAFIOUS IESTINATIONS EY FIFMS IN AFEA 2902, MISSOUFI

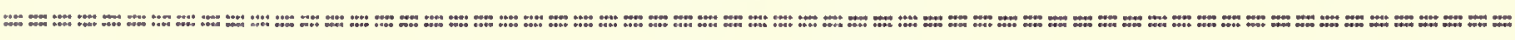

IIESTINATION

STATE OFI FORTT AFEEA
MONE OF TFANSFORTATION

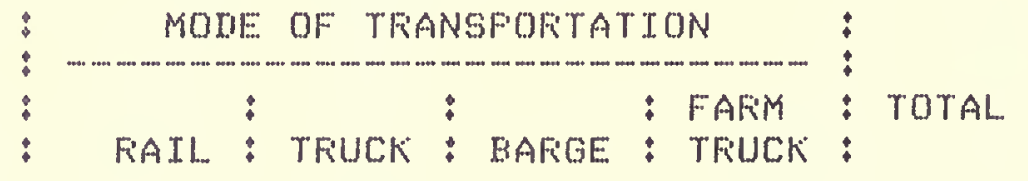

(THOUSANIIS OF BUSHELS)

$\begin{array}{llrrrrr}2261 & \text { ILLINOIS } & 0 & 1002 & 0 & 0 & 1002 \\ 2802 & \text { IOWA } & 98 & 625 & 0 & 0 & 723 \\ \text { TOTAL VOLUME } & 98 & 1627 & 0 & 0 & 1725\end{array}$


TABLE 120. 1977 COFN FECETFTS FFOM UAFTOUS OFIGINS ISY FIFIMS IN AFEA 2903 Y MISSOUFI

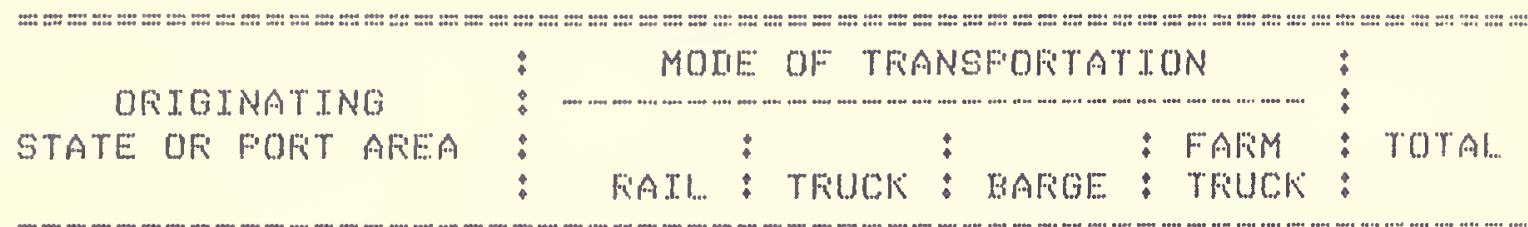

(THOUSANLIS OF BUSHE: S)

$\begin{array}{ll}1902 & \text { TNITANA } \\ 1903 & \text { TNITANA } \\ 2258 & \text { ILLTNOIS } \\ 2260 & \text { TLLINOIS } \\ 2262 & \text { ILLTNOIS } \\ 2319 & \text { KENTUCKY } \\ 2801 & \text { TOWA } \\ 2802 & \text { IOWA } \\ 2803 \text { TOWA }\end{array}$

TOTAL VOLUME:

$\begin{array}{rrrrr}153 & 0 & 0 & 0 & 153 \\ 652 & 6 & 0 & 0 & 656 \\ 352 & 6320 & 0 & 0 & 6672 \\ 0 & 1983 & 0 & 0 & 1983 \\ 175 & 112 & 0 & 0 & 237 \\ 102 & 26 & 0 & 0 & 128 \\ 146 & 2366 & 0 & 0 & 2515 \\ 235 & 187 & 0 & 0 & 424 \\ 0 & 79 & 0 & 0 & 79 \\ 1815 & 1.1081 & 0 & 0 & 12896\end{array}$

TARLE 121. 1977 COFN SHIFMENTS TO VAFTOUS DESTINATIONS EY FIFMS IN AFIEA 2903, MISSOUFIT

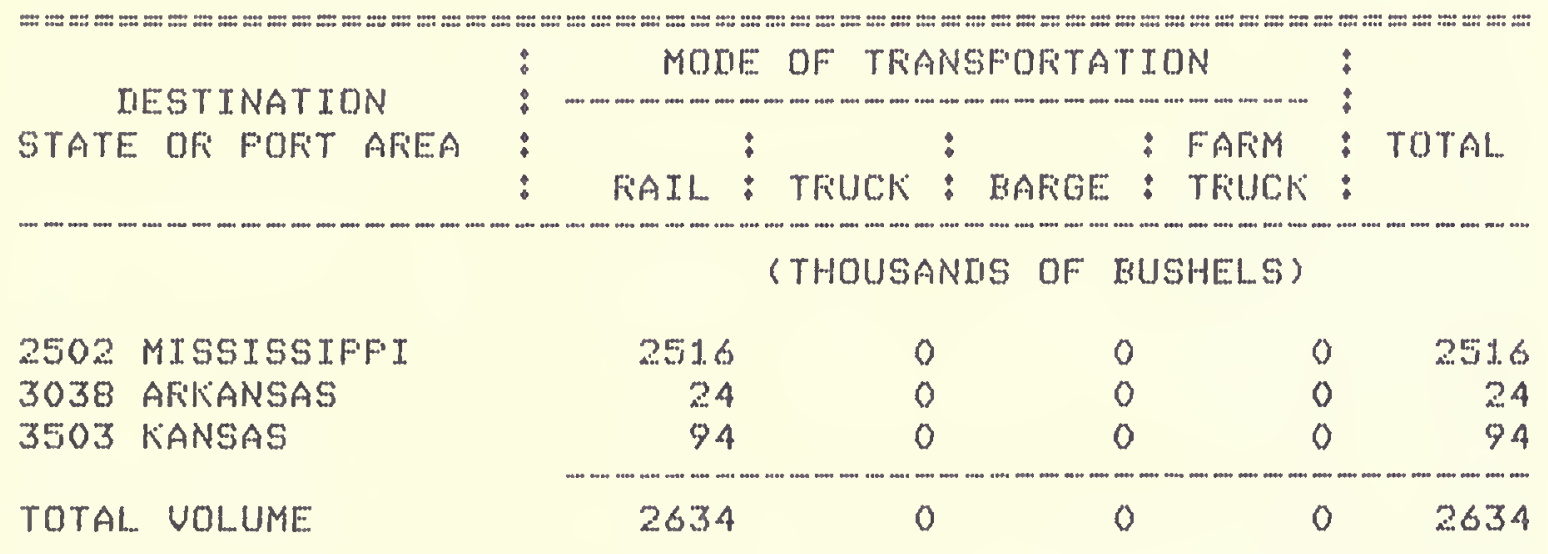


TAELE 122. 1977 COFN FECEIFTS FFOM VAFTOUS OFIGINS BY FIFMS TN AFEA 2904 , MISSOUFI

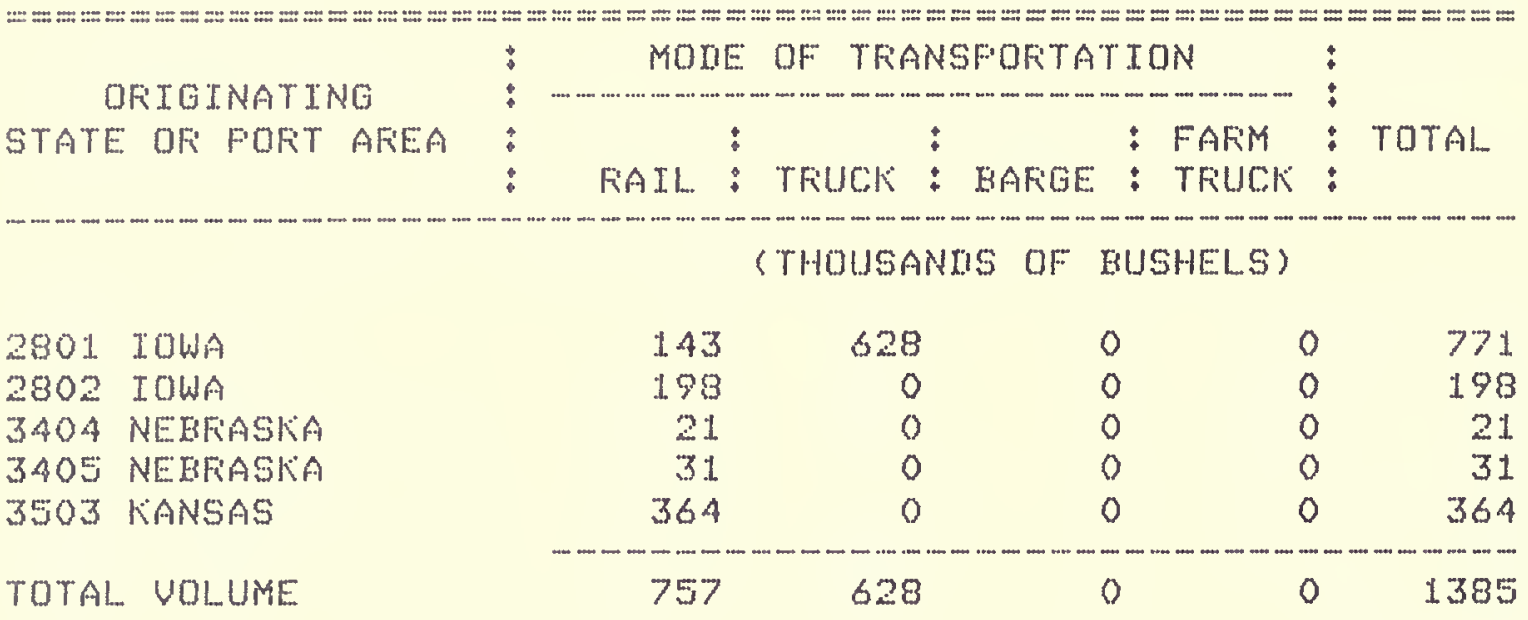

TABLE 123. 1977 COFN FECEIFTS FFOM UAFIOUS OFIGINS BY FTFMS IN AFEA 3.4OL, NEBFASKA

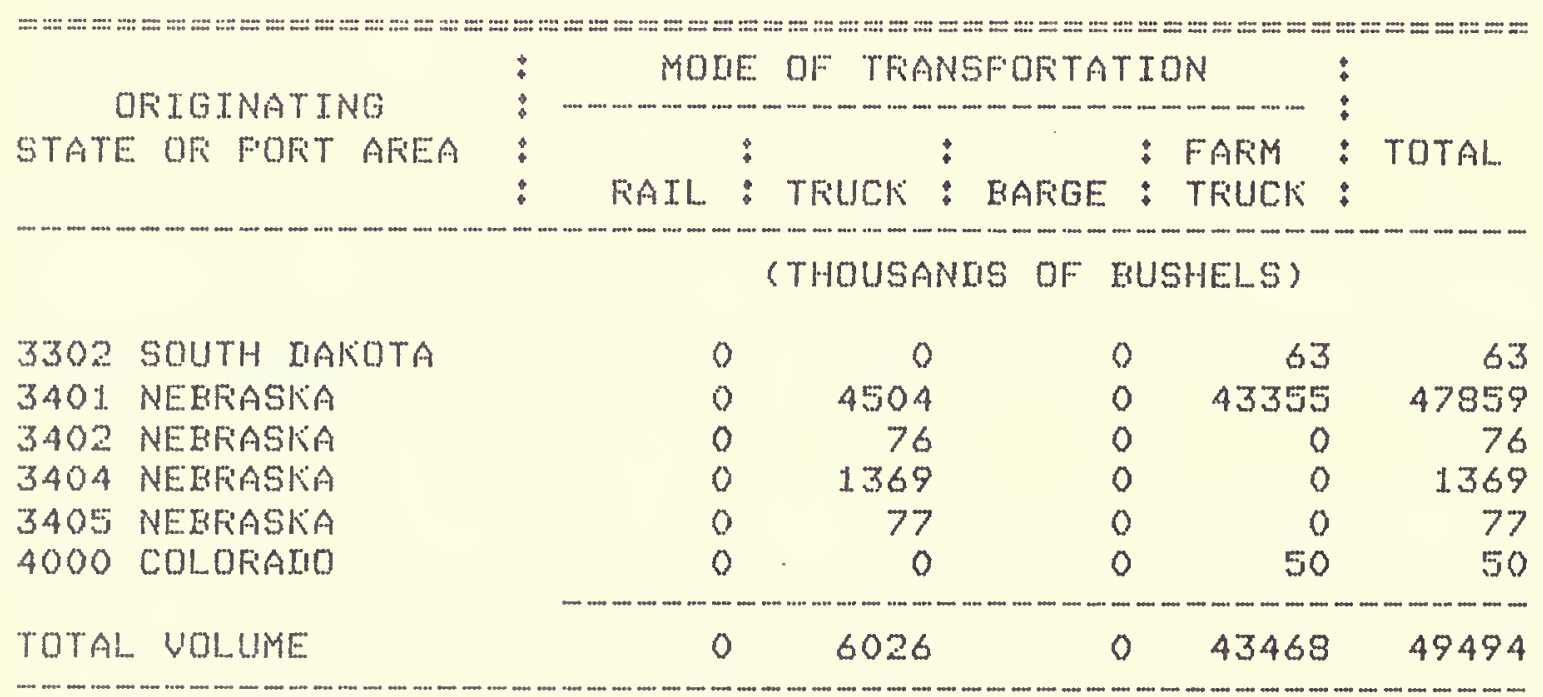


TAELE J.2A. 1977 COFN SHIFMENTS TO VAFIOUS DESTINATTONS BY FTRMS IN AFEA 3401, NEBFASKIA

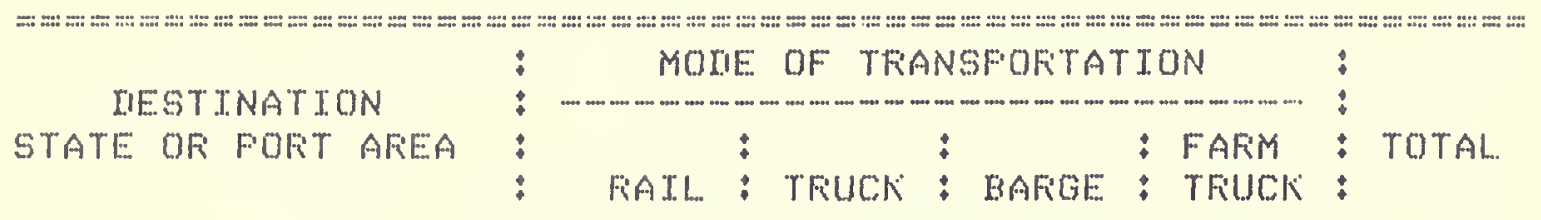

\begin{tabular}{|c|c|c|c|c|c|c|}
\hline \multirow[b]{2}{*}{3302} & \multirow[b]{2}{*}{ SOUTH IIAKOOTA } & \multicolumn{2}{|c|}{ STHOUSANIS OF } & \multicolumn{2}{|c|}{ BUSHELSS) } & \multirow[b]{2}{*}{252} \\
\hline & & 0 & 0 & 0 & 252 & \\
\hline 3401 & NEEFIASKA & 0 & 4504 & 0 & 7133 & 1. 1637 \\
\hline 3404 & NEBFASK゙A & 775 & 0 & 0 & 142 & 91.7 \\
\hline 3405 & NEBFIASKRA & 0 & 9 & 0 & 53 & 62 \\
\hline 3501 & KKANSAS & 0 & 425 & 0 & 209 & 634 \\
\hline 3601 & OKILAHOMA & 0 & 25 & 0 & 0 & 25 \\
\hline 3711 & TEXAS & 0 & 2816 & 0 & 0 & 2816 \\
\hline 3900 & WYOMING & 0 & 65 & 0 & 1.41 & 206 \\
\hline 4000 & COLOFADO & $813 \%$ & 1.471 & 0 & 5660 & 15270 \\
\hline 4701 & CALIFOFNIA & 750 & 0 & 0 & 0 & 730 \\
\hline 4703 & CALI..TFORNIA & 1715 & 0 & 0 & 0 & $171 \%$ \\
\hline 7401 & COLUMETA RJUEF & 38 & 0 & 0 & 0 & 38 \\
\hline TOTAI. & VOL..UME: & 1.1.417 & 9315 & 0 & 13590 & 34322 \\
\hline
\end{tabular}

TAELE 125, 1977 COFN FECEIFTS FFOM UARIOUS OFIGINS BY FIFMS IN AFIEA 3AOZ, NEBFASKIA

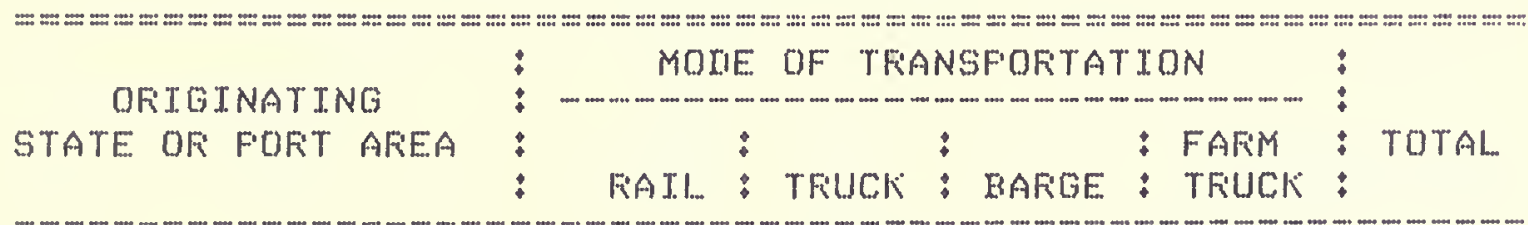

(THOUSANDS OF RUSHELS)

\begin{tabular}{|c|c|c|c|c|c|}
\hline 3402 NEBFASKIA & 0 & 0 & 0 & 11538 & 1.1.538 \\
\hline 3403 NEAFIASKIA & 0 & 0 & 0 & 119 & 119 \\
\hline 3404 NEBFASKEA & 0 & 0 & 0 & 1395 & 1395 \\
\hline OTAL VOL_UME & 0 & 0 & 0 & 13052 & 13052 \\
\hline
\end{tabular}


TAELE 1.26. 1977 COFN SHIFMENTS TO UAFIOUS RESTINATIONS BY FIFIMS IN AFIEA 3402 Y NEBFIASKIA

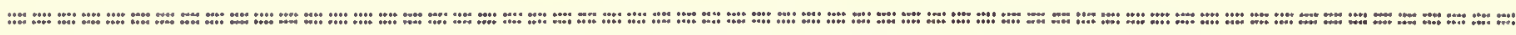

DESTINATION

STATE OF FOFT AKEA
MOIE OF TFANSFOFTATION

: : : FAFIM : TOTAL.

(THOUSANIS OF KUSHELS..S

3401. NEBFAASKA

3402 NEBKAASKA

3AOA NEBFASKA

3405 NEERASKA

4000 COLOFIATO

7303 NO. TEXAS GUL..F

TOTAL VOLUME

\begin{tabular}{rrrrr}
0 & 76 & 0 & 0 & 76 \\
0 & 0 & 0 & 579 & 579 \\
272 & 410 & 0 & 0 & 682 \\
10381 & 0 & 0 & 0 & 10381 \\
198 & 0 & 0 & 0 & 198 \\
29 & 0 & 0 & 0 & 29 \\
\hline 10880 & 486 & 0 & 579 & 11945
\end{tabular}

TARLE 127. 1977 COFN FECEIFTS FFOM UAFIOUS OFIGINS BY FIFMS IN AFEA 3403, NEBFRASKA

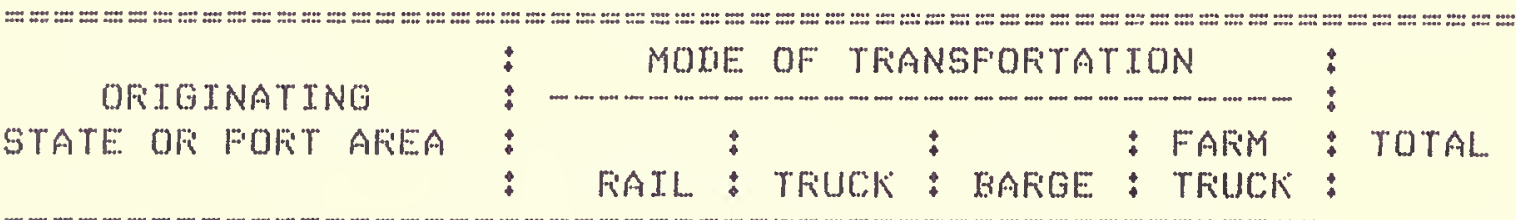

(THOUSANISS OF EUSHELS)

2801 IOWA

3301 SOUTH IIAKOTA

3403 NERFASIIA

3405 NEBFIASKA

TOTAL VOLUME

\begin{tabular}{rrrrr}
11 & 2310 & 0 & 589 & 2910 \\
92 & 312 & 0 & 196 & 500 \\
1191 & 12657 & 0 & 51225 & 65073 \\
0 & 973 & 0 & 0 & 973 \\
\hline 1294 & 1.6252 & 0 & 52010 & 69556
\end{tabular}


TAELE 128. 1977 COFN SHIFMENTS TO UAFIOUS IIESTINATIONS BY FIFIMS IN AFIEA 3403, NEBFIASKA

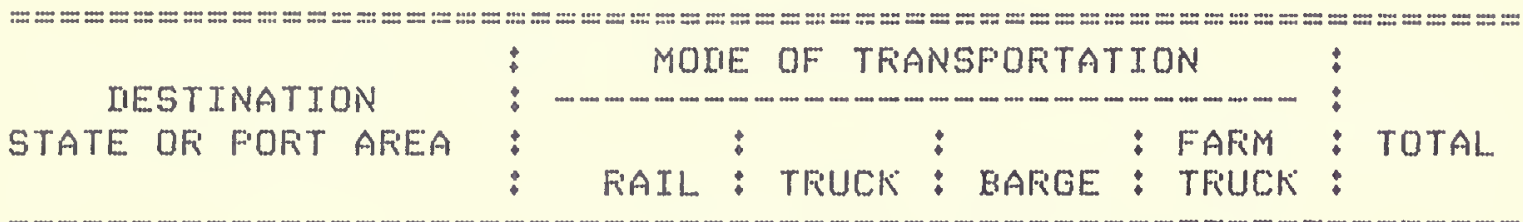

\section{(THOUSANIIS OF BUSHELS)}

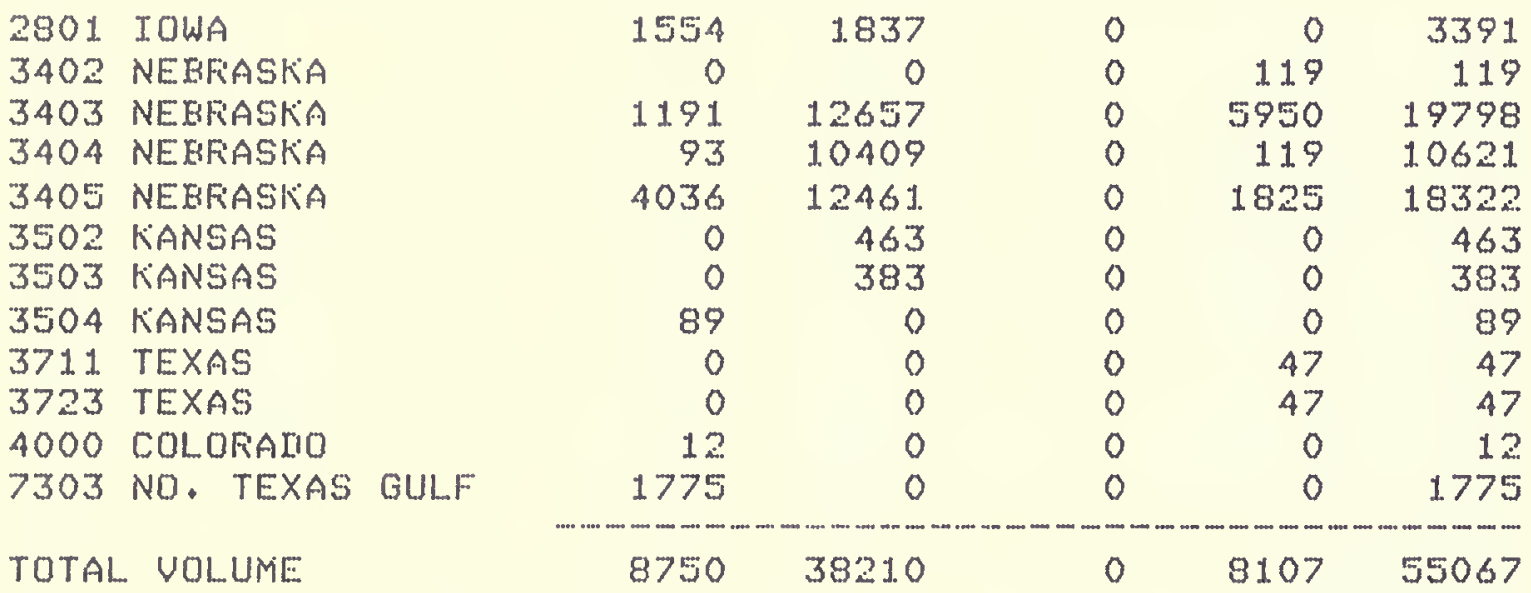

TAELE 129, 1977 COFN FECEIFTS FFOM UAFIOUS OFIGINS RY FIFIMS IN AFEA 3404 , NEBFIASKKA

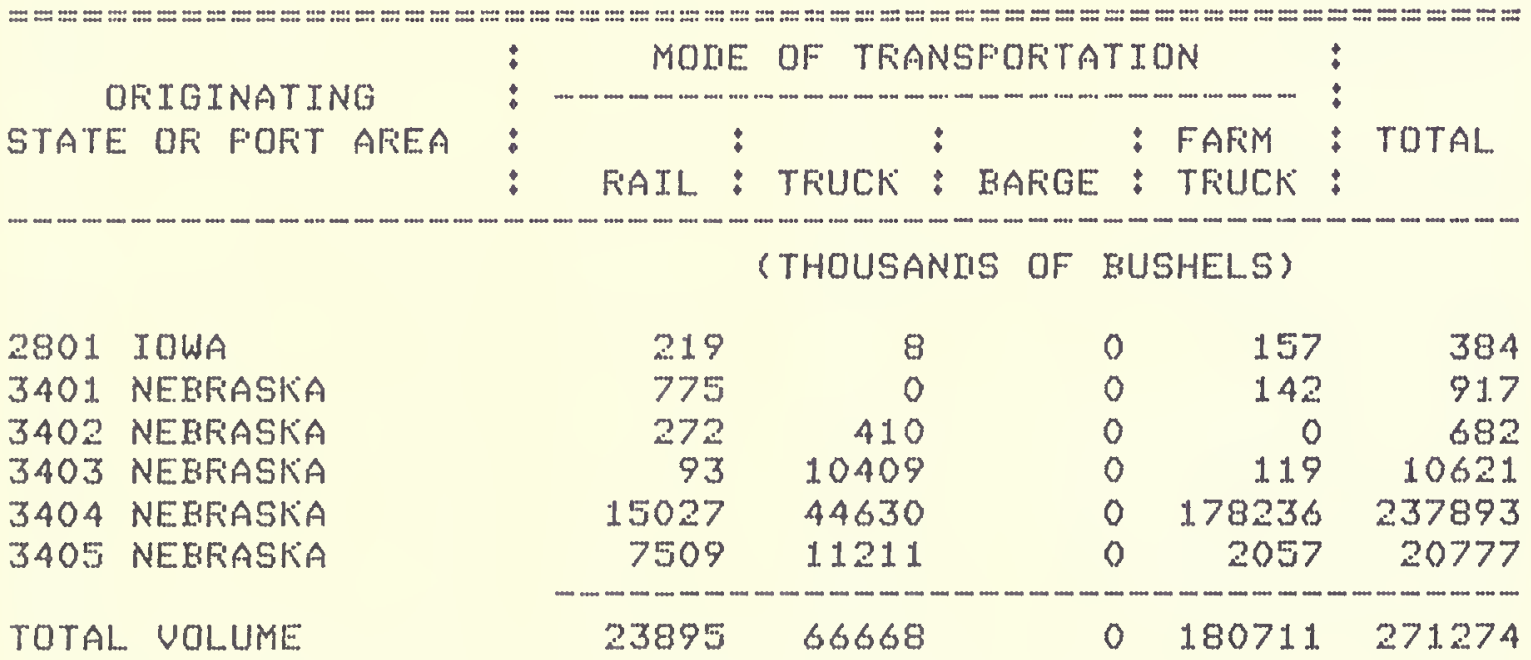


TAELE 130. 1977 COFIN SHIFMENTS TO UAFIOUS DESTINATIONS EY FIFMS IN AFEEA 3404y NEBFASKKA

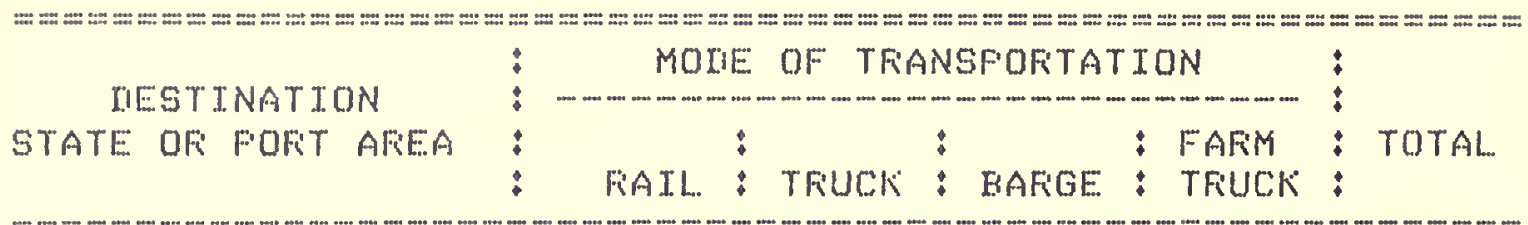

(THOUSANIIS OF BUSHELS)

\begin{tabular}{|c|c|c|c|c|c|c|}
\hline 2412 & TENNESSEE & 3 & 0 & 0 & 0 & 3 \\
\hline 2801 & TOWA & 52 & 0 & 0 & 0 & 52 \\
\hline 2901 & MISSOUFT. & 1076 & 10 & 0 & 0 & 1086 \\
\hline 2904 & MISSOUFI & 21 & 0 & 0 & 0 & 21 \\
\hline 3016 & AFiKKANSAS & 7740 & 0 & 0 & 0 & 7740 \\
\hline 3100 & LOUTSIANA & 197 & 0 & 0 & 0 & 197 \\
\hline 3401 & NEBFIASKEA & 0 & 1369 & 0 & 0 & 1369 \\
\hline 3402 & NESFASKIA & 0 & 0 & 0 & 1395 & 1395 \\
\hline 3404 & NEEFIASKKA & 15027 & 44630 & 0 & 13829 & 73486 \\
\hline 3405 & NEEFIASKIA & 103 & $220 \%$ & 0 & 2120 & 5360 \\
\hline 3501 & K゙ANSAS & 6680 & 0 & 0 & 2675 & 9355 \\
\hline 3502 & KANSAS & 223 & 7491 & 0 & 1202 & 8916 \\
\hline 3503 & KKANSAS & 1525 & 510 & 0 & 0 & 2035 \\
\hline 3504 & KANSAS & 70 & 40 & 0 & 0 & 110 \\
\hline 3505 & K゙ANSAS & 478 & 0 & 0 & 0 & 478 \\
\hline 3602 & OKKLAHOMA & 75 & 0 & 0 & 0 & 75 \\
\hline 3604 & OKKL... AHOMA & 20 & 736 & 0 & 0 & 756 \\
\hline 3711 & TEXAS & 729 & 0 & 0 & 0 & 729 \\
\hline 3712 & TEXAS & 8 & 36 & 0 & 0 & 44 \\
\hline 3723 & TEXAS & 60 & 10 & 0 & 0 & 70 \\
\hline 3745 & TEXAS & 10 & 10 & 0 & 0 & 20 \\
\hline 3789 & TEXAS & 1821 & 0 & 0 & 0 & 1821 \\
\hline 3900 & WYOMING & 0 & 56 & 0 & 761 & 817 \\
\hline 4000 & COLOFIACIO & 26002 & 0 & 0 & 3835 & 29837 \\
\hline 4300 & UTAH & 2351 & 0 & 0 & 0 & 2351 \\
\hline 4400 & $A F] Z O N A$ & 1511 & 36 & 0 & 0 & 1547 \\
\hline 4500 & WASHTNGTON & 3953 & 0 & 0 & 0 & 3953 \\
\hline 4600 & OFEGON & 1415 & 0 & 0 & 0 & 1415 \\
\hline 4701 & CALIFOFNIA & 13442 & 0 & 0 & 0 & 13442 \\
\hline 4703 & CAL.. IFOFNNA & 34881 & 0 & 0 & 0 & 34881 \\
\hline 4704 & CAL IFOFNIA & 12062 & 0 & 0 & 0 & 12062 \\
\hline 4800 & NEUAIIA & 162 & 0 & 0 & 0 & 162 \\
\hline 7301 & EAST GULF & 135 & 0 & 0 & 0 & 135 \\
\hline 7302 & LOUISTANA GULF & 611 & 0 & 0 & 0 & 611 \\
\hline 7303 & NO. TEXAS GULF & 10306 & 0 & 0 & 0 & 10306 \\
\hline 7304 & SO. TEXAS GULF & 9 & 0 & 0 & 0 & 9 \\
\hline 7401 & COLLUMEIA FIIUEF & 2111 & 0 & 0 & 0 & 2111 \\
\hline 7402 & FUGET SOUNI & 3532 & 0 & 0 & 0 & 3532 \\
\hline 7403 & CALIFOFINIA & 9708 & 0 & 0 & 0 & 9708 \\
\hline TOTAL & - UOL.UME & 159041 & 57139 & 0 & 25817 & 241997 \\
\hline
\end{tabular}


TABLE 131. 1.977 COFN FECETFTS FFOM UAFIOUS OFTGINS EY FIFMS IN AFEEA 3405 , NEBFASKKA

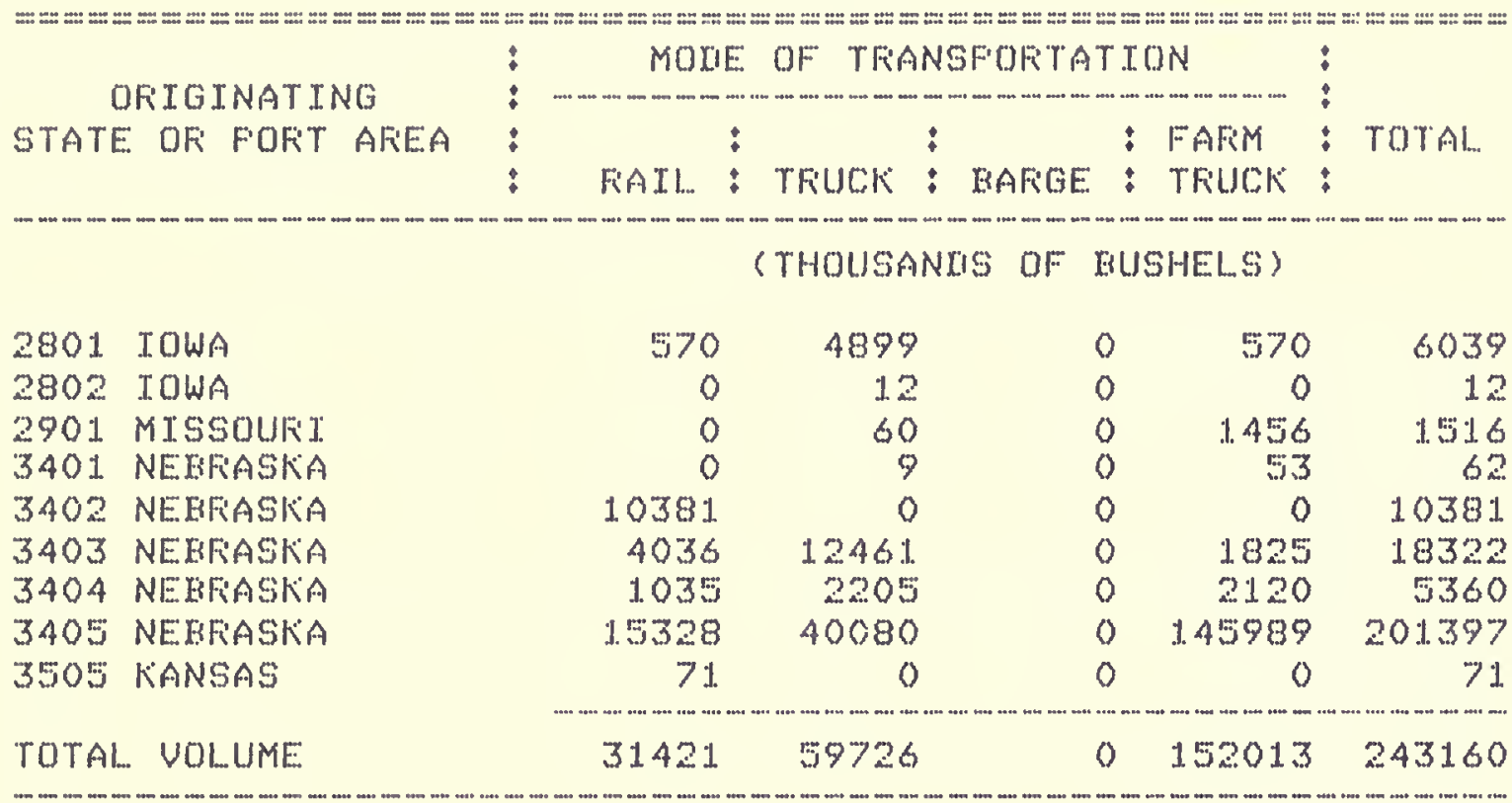


TABLE 132. 1.977 COFN SHIFMENTS TO UAFIOUS IIESTINATIONS BY FIFMS IN AFEA 3405, NERFIASKA

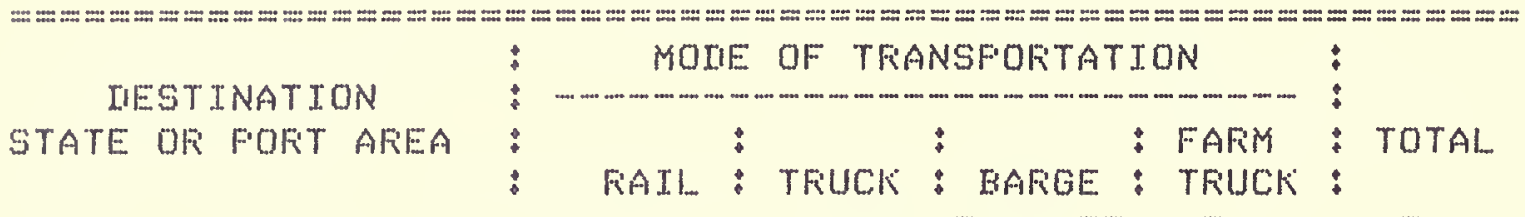

\begin{tabular}{|c|c|c|c|c|c|c|}
\hline \multirow[b]{2}{*}{2503} & \multirow[b]{2}{*}{ MISSISSIFFI } & \multicolumn{3}{|c|}{ (THOUSANIIS OF } & BUSHELS) & \multirow[b]{2}{*}{3458} \\
\hline & & 3458 & 0 & 0 & 0 & \\
\hline 2705 & MINNESOTA & 206 & 47 & 0 & 0 & 253 \\
\hline 2801 & IOWA & 1240 & 10 & 0 & 0 & 1250 \\
\hline 2802 & IOWA & 2 & 0 & 0 & 0 & 2 \\
\hline 2901 & MISSOUFI & 8014 & 94 & 0 & 0 & 8108 \\
\hline 2904 & MISSOUFI & 31 & 0 & 0 & 0 & 31 \\
\hline 3005 & AFKIANSAS & 117 & 0 & 0 & 0 & 117 \\
\hline 3016 & AFIKANSAS & 18490 & 1.477 & 0 & 1541 & 21508 \\
\hline 3017 & AFKIANSAS & 167 & 0 & 0 & 0 & 167 \\
\hline 3038 & AFIKANSAS & 1.9 & 0 & 0 & 0 & 19 \\
\hline 3100 & LOUISTANA & 127 & 0 & 0 & 0 & 127 \\
\hline 3401 & NEBRASKA & 0 & 77 & 0 & 0 & 77 \\
\hline 3403 & NEEFIASKIA & 0 & 973 & 0 & 0 & 973 \\
\hline 3404 & NEEFIASKIA & 7509 & 11211 & 0 & 2057 & 20777 \\
\hline 3405 & NERFIASKIA & 15328 & 40080 & 0 & 6258 & 61666 \\
\hline 3501 & K゙ANSAS & 0 & 0 & 0 & 487 & 487 \\
\hline 3502 & KEANSAS & 2737 & 152 & 0 & 0 & 2889 \\
\hline 3503 & KAANSAS & 4137 & 4704 & 0 & 0 & 8841 \\
\hline 3504 & KANSAS & 89 & 547 & 0 & 0 & 636 \\
\hline 3505 & KAANSAS & 1568 & 1.4 & 0 & 0 & 1582 \\
\hline 3602 & OKLAHOMA & 182 & 0 & 0 & 0 & 182 \\
\hline 3604 & OKKLAHOMA & 448 & 1159 & 0 & 0 & 1607 \\
\hline 3710 & TEXAS & 160 & 168 & 0 & 0 & 328 \\
\hline 3711 & TEXAS & 21 & 0 & 0 & 324 & 345 \\
\hline 3712 & TEXAS & 36 & 420 & 0 & 324 & 780 \\
\hline 3723 & TEXAS & 294 & 52 & 0 & 0 & 346 \\
\hline 3745 & TEXAS & 950 & 927 & 0 & 0 & 1877 \\
\hline 3767 & TEXAS & 0 & 0 & 0 & 324 & 324 \\
\hline 3789 & TEXAS & 11.49 & 0 & 0 & 0 & 1149 \\
\hline 3900 & WYOMING & 0 & 7 & 0 & 0 & 7 \\
\hline 4000 & COLOFIAIIO & 1268 & 472 & 0 & 618 & 2358 \\
\hline 4400 & AFIZONA & 32 & 0 & 0 & 0 & 32 \\
\hline 4703 & CALIFOFNIA & 1175 & 0 & 0 & 0 & 1.175 \\
\hline 4704 & CALIFOFINIA & 665 & 0 & 0 & 0 & 665 \\
\hline 7301 & EAST GULF & 45 & 0 & 0 & 0 & 45 \\
\hline 7302 & LOUISTANA GULF & 0 & 0 & 1825 & 0 & 1825 \\
\hline 7303 & NO. TEXAS GULF & 4980 & 0 & 0 & 0 & 4980 \\
\hline 7304 & SO. TEXAS GULF & 20 & 0 & 0 & 0 & 20 \\
\hline 7401 & COLUMETA FIUEF & 412 & 0 & 0 & 0 & 412 \\
\hline 7402 & FUGET SOUND & 421 & 0 & 0 & 0 & 421 \\
\hline 7403 & CALIFOFNIA & 551 & 0 & 0 & 0 & 551 \\
\hline
\end{tabular}


TAELE 133. 1977 COFN FIECETFTS FFOM UAFTOUS OFIGINS BY FIFIMS IN AFEA 4800, NEUAIA

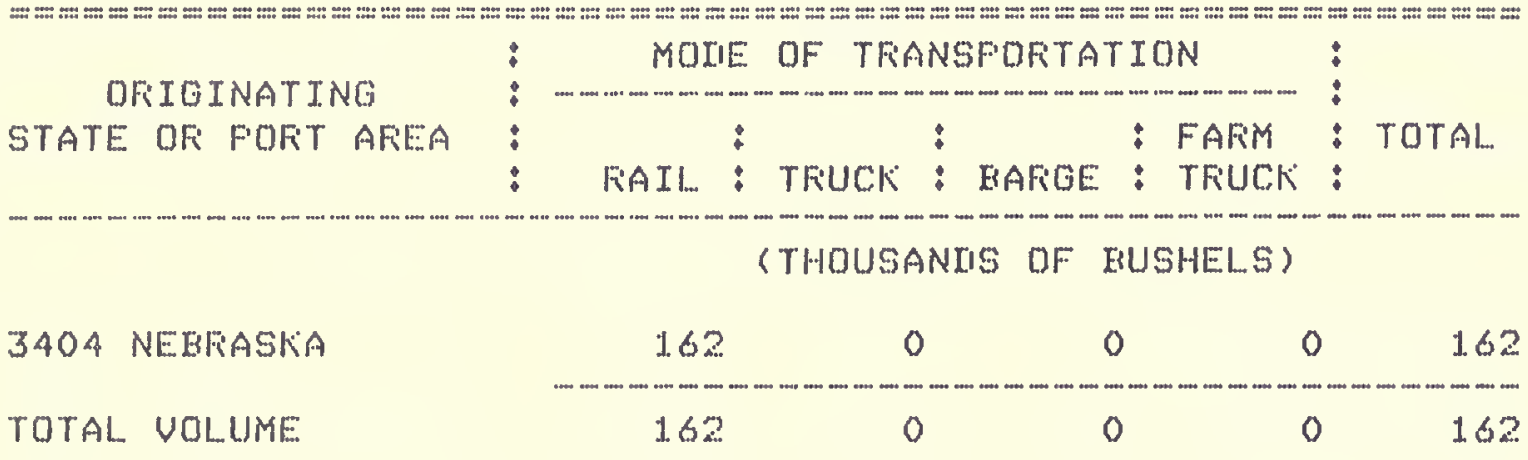

TAELE 134. 1977 COFN FECETFTS FFOM UAFIOUS OFIGINS EY FIFMS IN AFIEA 200, NEW HAMFSHTFE:

\begin{tabular}{|c|c|c|c|c|c|c|}
\hline \multirow{3}{*}{$\begin{array}{l}\text { OFIGINATING } \\
\text { STATE OF FOFT AFEA }\end{array}$} & \multirow{3}{*}{$\begin{array}{r}\quad \text { MOII } \\
\vdots \\
\vdots\end{array}$} & \multicolumn{3}{|c|}{ E OF TFIANSFOFITATTON } & \multirow{3}{*}{$\vdots$} & \multirow{3}{*}{ TOTAL. } \\
\hline & & : & $:$ & : FAFIM & & \\
\hline & & : TFUUCK & : FAFIGE & : TFUCK & & \\
\hline & \multicolumn{3}{|c|}{ (THOUSANIIS OF } & RUSHELS) & & \\
\hline 701 NEW YOFKK & 8 & 3 & & 0 & 0 & 116 \\
\hline 901. FENNSYLUANIA & 6 & & 0 & 0 & 0 & 64 \\
\hline 903 FENNSYLUANIA & 1. & & 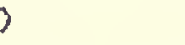 & 0 & 0 & 14 \\
\hline TOTAL VOLUME & 1.6 & 3 & & 0 & 0 & 194 \\
\hline
\end{tabular}

TAELE 135. 1977 COFIN FEECIFTS FFOM UAFIOUS ORIGINS BY FIFIMS IN AFEA 800, NEW JERSEY

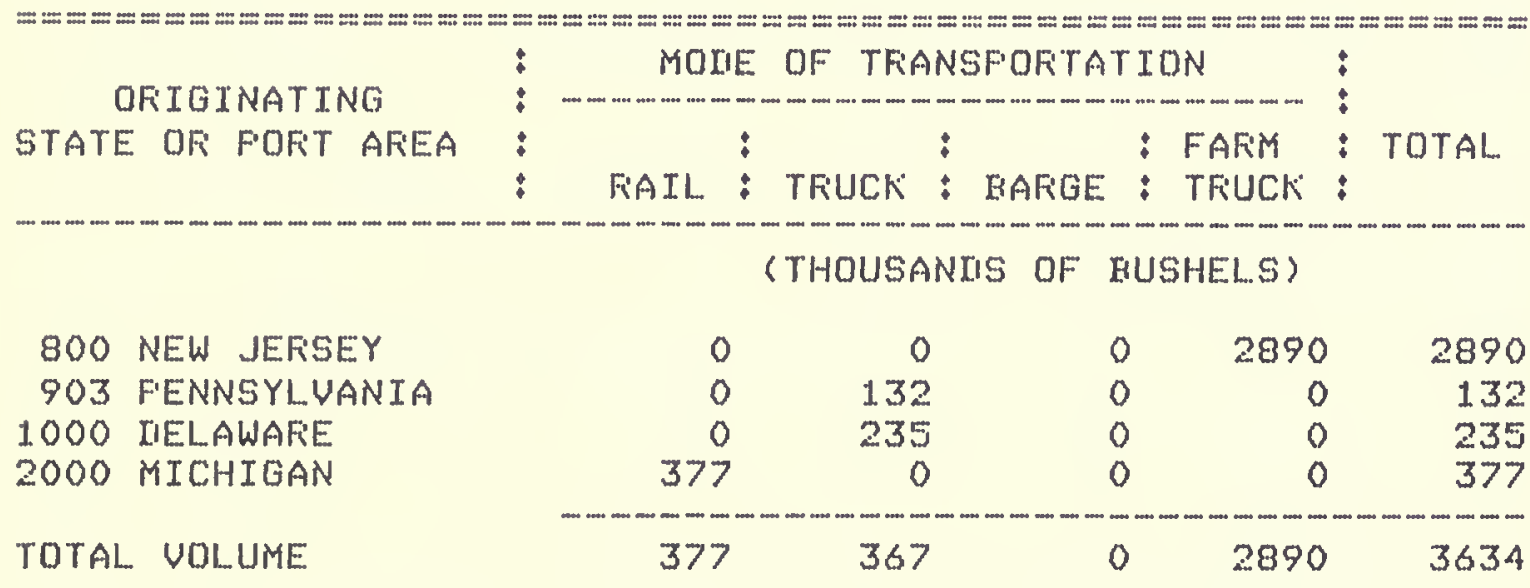


TABLE 136. 1977 COFN SHTFMENTS TO UAFIOUS RIESTINATIONS BY FIVMS IN AFEA BOOY NEW JEFGEY

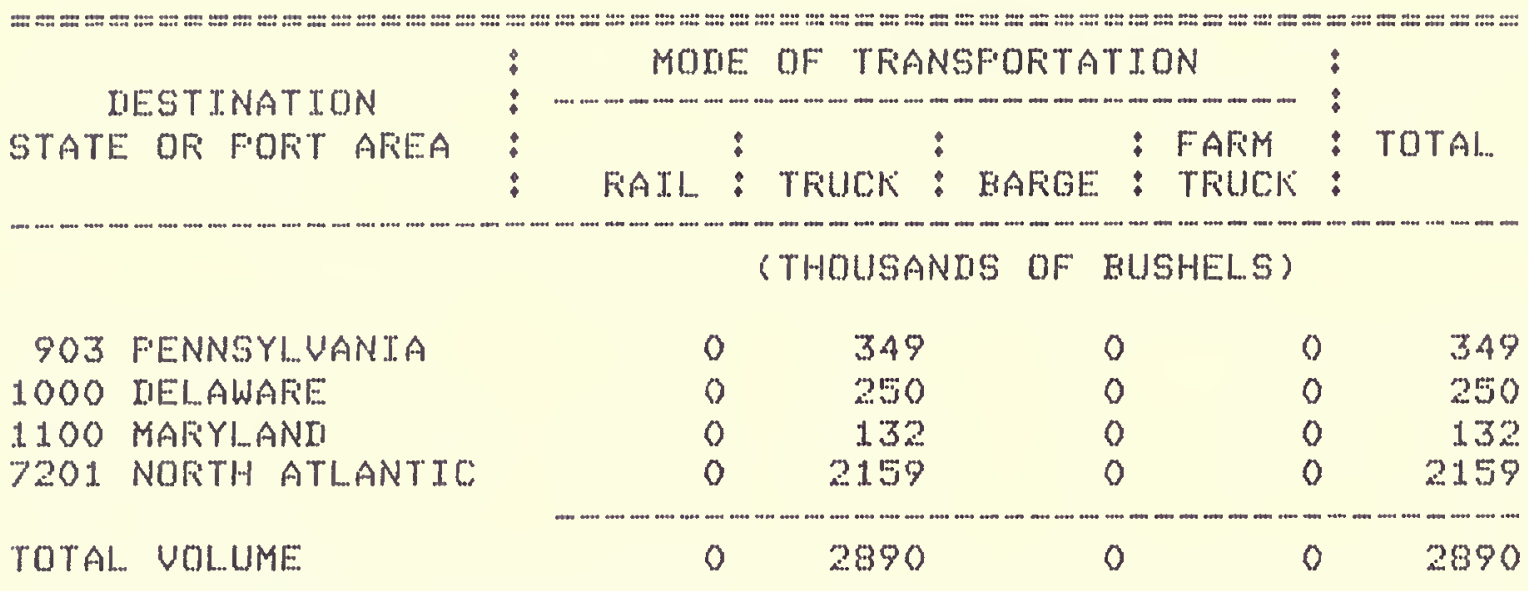

TAELE 137. 1977 COFN FECETFTS FFOM UAFIOUS OFIGINS EY FIFIMS IN AFIEA 4100 , NEW MEXTCO

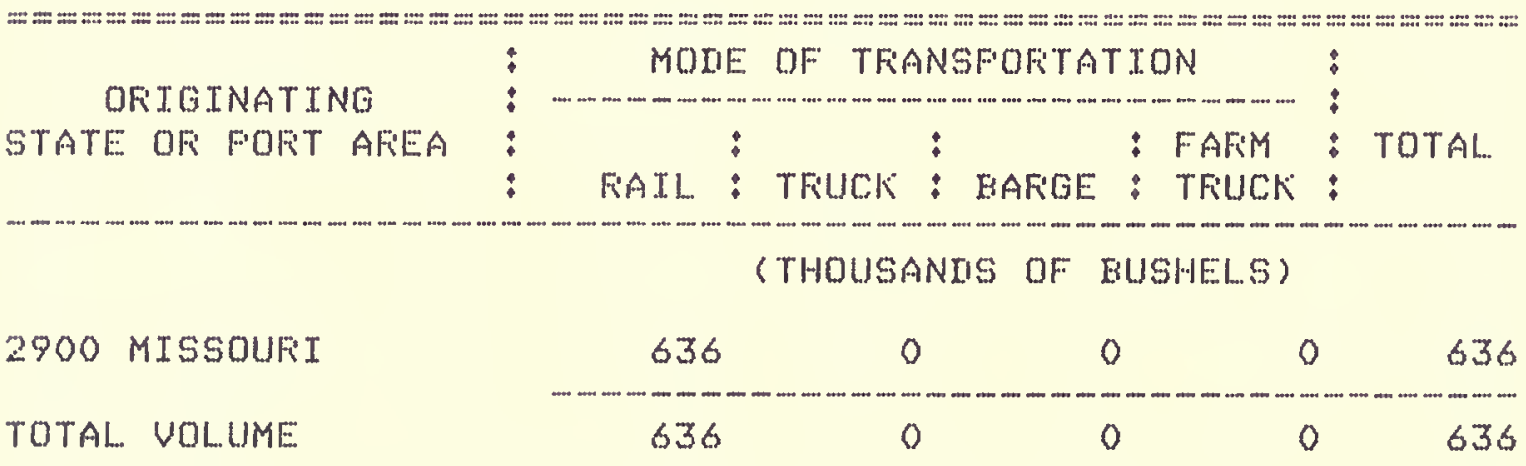

TAELE 138. 1977 COFIN SHIFMENTS TO VAFIOUS IIESTINATIONS FY FIFIMS IN AFEA 4100 , NEW MEXICO

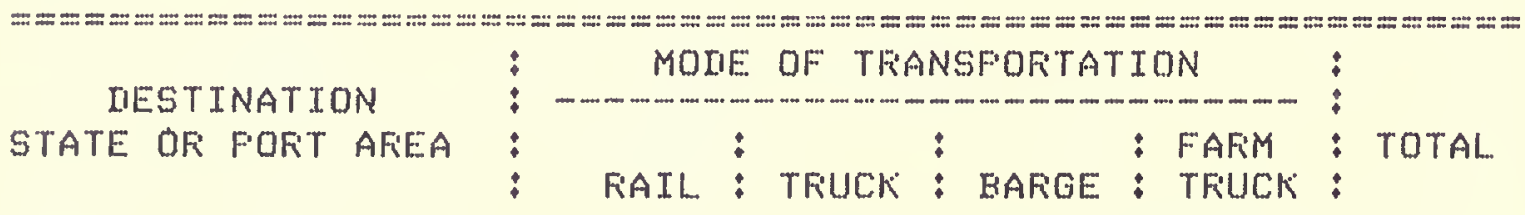

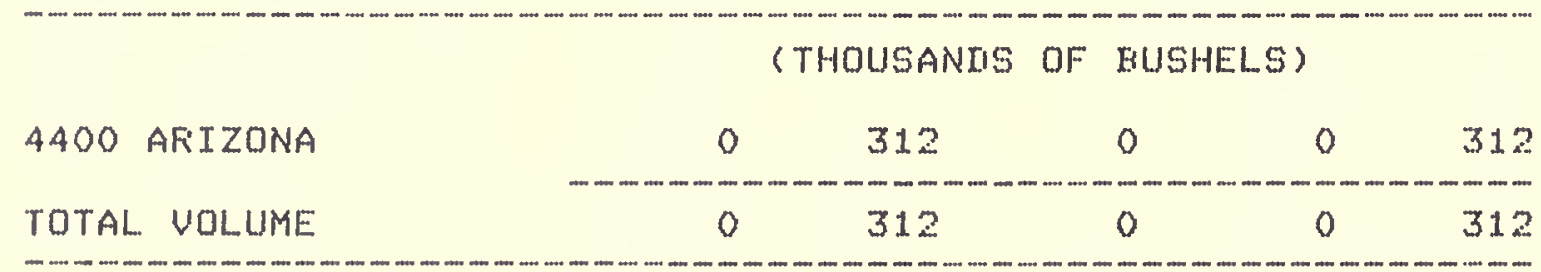


TAELE 139. 1977 COFIN FIECEIFTS FFOM UAFIOUS OFIGINS BY FIFIMS IN AFEA 701 , NEW YOFK

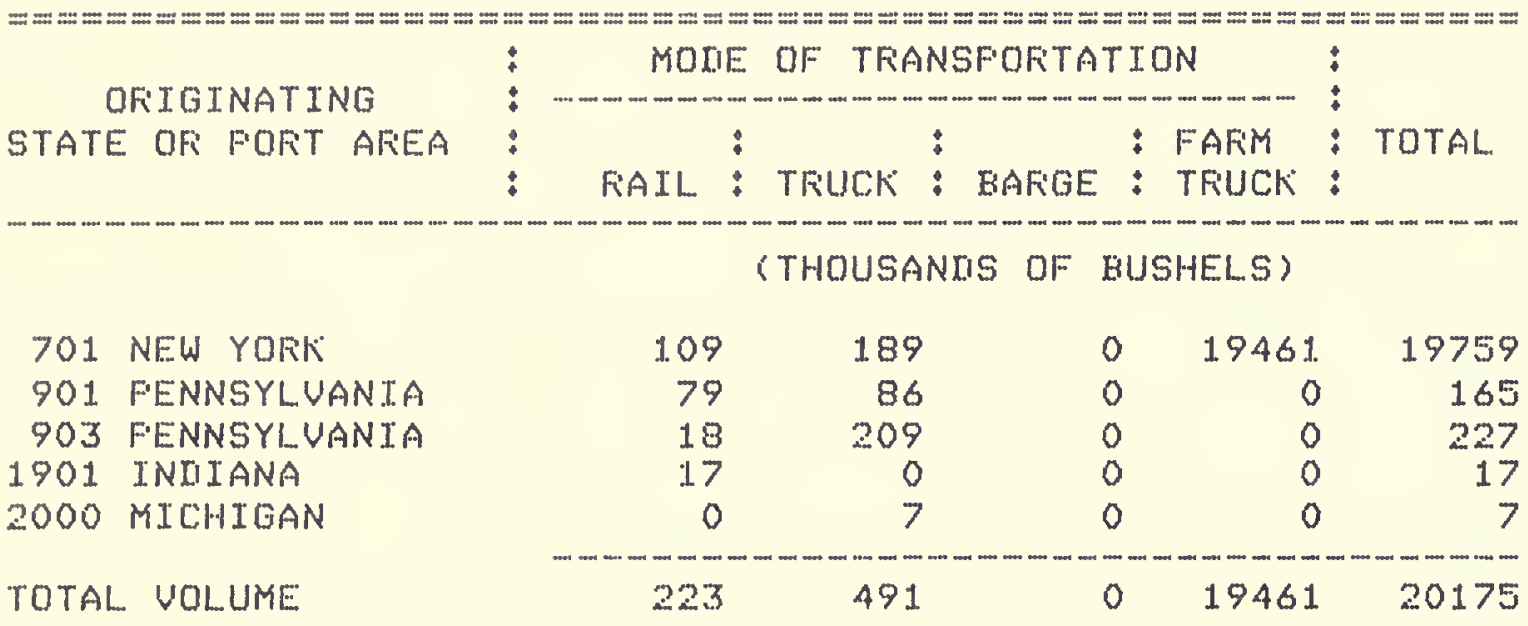

TAELE 140. 1977 COFN SHIFMENTS TO VAFIOUS IIESTINATIONS EY FIFIMS IN AFIEA 701. NEW YOFIK

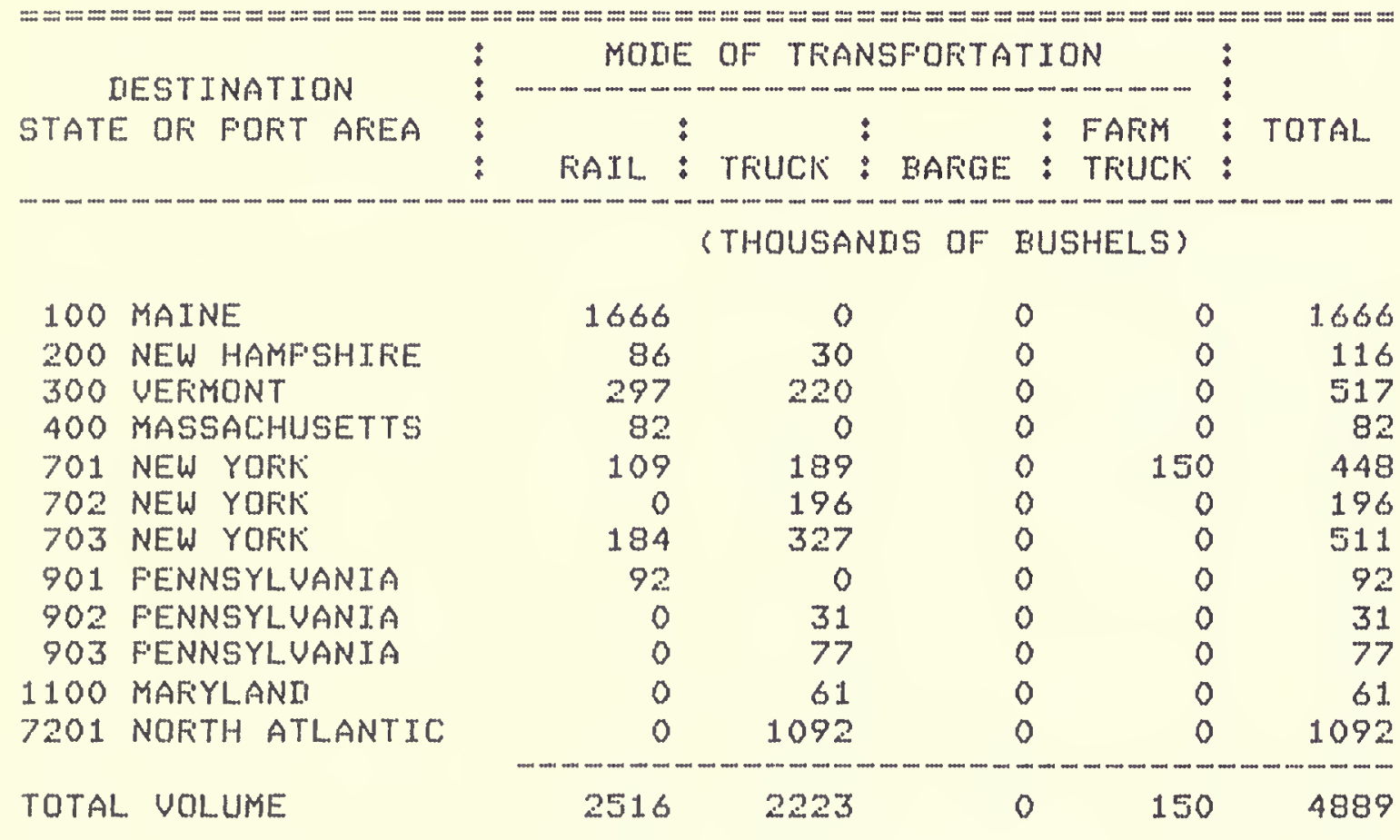


TABLE 141. 1977 COFN FECEIFTS FFOM UAFITUUS OFIGINS EY FIFMS IN AFEA 702, NEW YOFIK

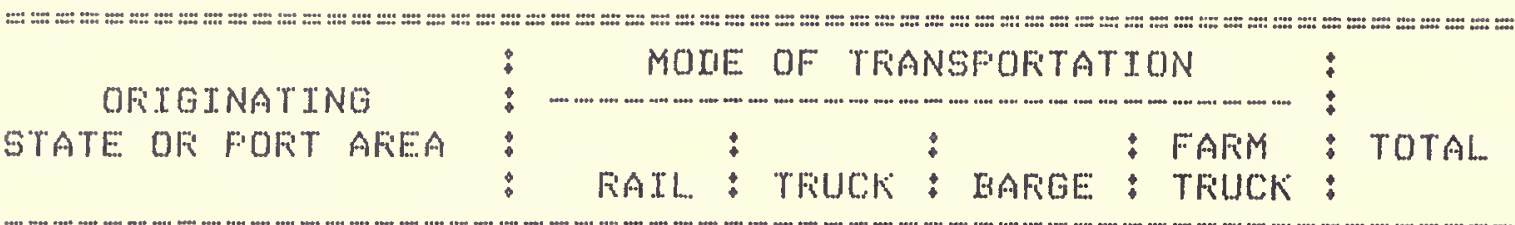

(THOUSANRS OF EUSHELS)

$\begin{array}{cccccc}701 \text { NEW YOFK } & 0 & 196 & 0 & 0 & 196 \\ 702 \text { NEW YOFK } & 0 & 0 & 0 & 216 & 216 \\ 1850 \text { OHIO } & 43 & 0 & 0 & 0 & 43 \\ \text { TOTAL VOLUME } & 43 & 196 & 0 & 216 & 455\end{array}$

TAELE 142, 1977 COFN FECETFTS FFOM UAFIOUS OFIGINS BY FIFIS IN AFEA 703 , NEW YOFKL

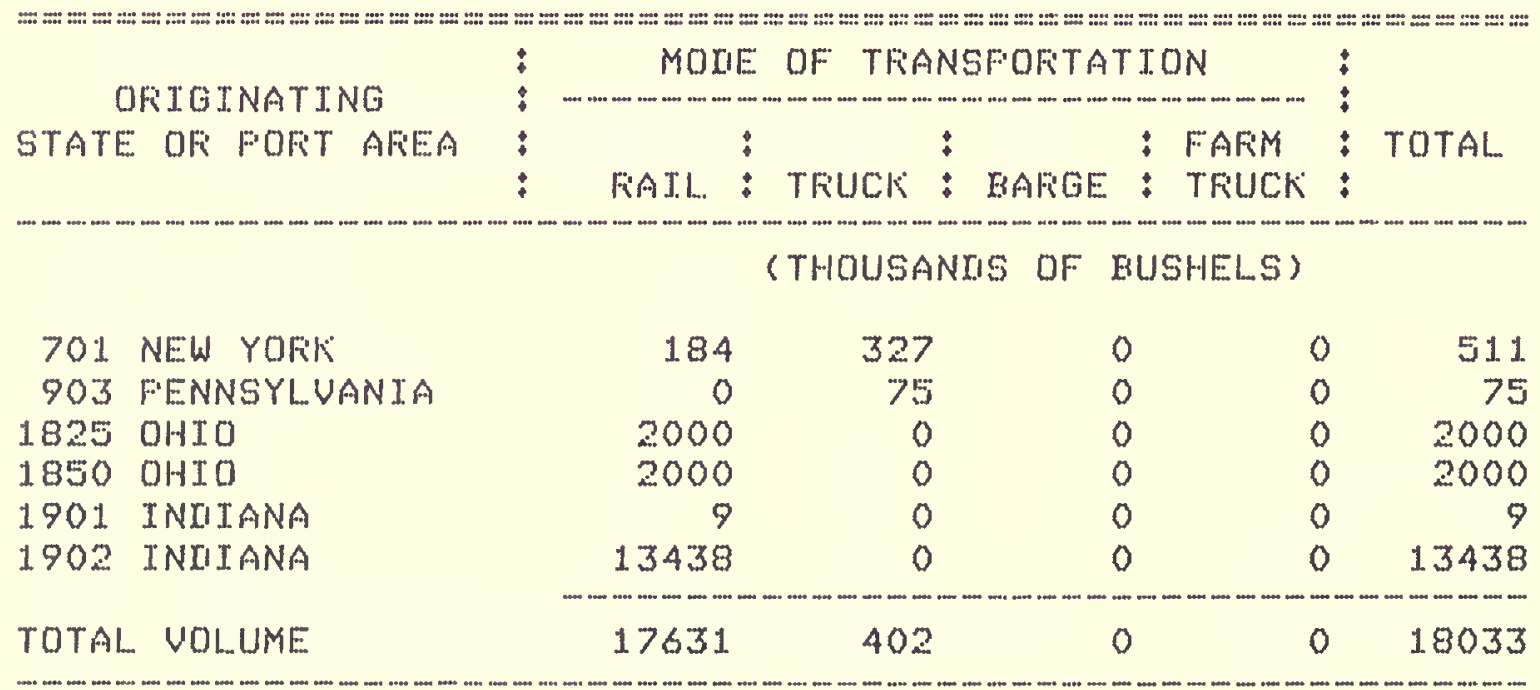


TABLE 143. 1977 COFN FECEIFTS FFOM UAFIOUS ORIGINS BY FIFIMS IN AFEA 1400, NOFTH CAFIOLINA

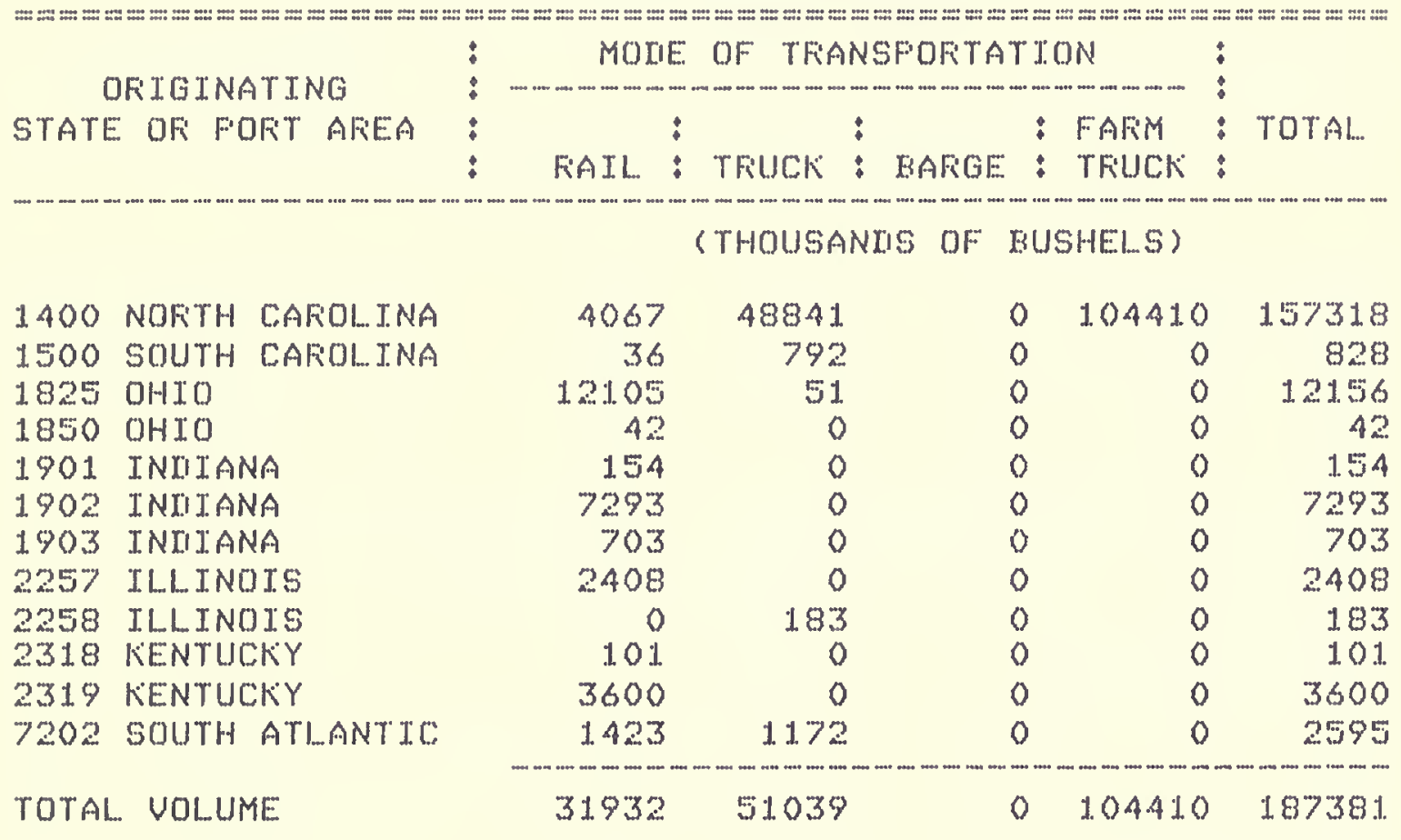

TABLE 144. 1977 COFN SHIFMENTS TO UAFITUUS MIESTINATIONS BY FIFIMS IN AFEA 1400, NOFTH CAFIOLINA

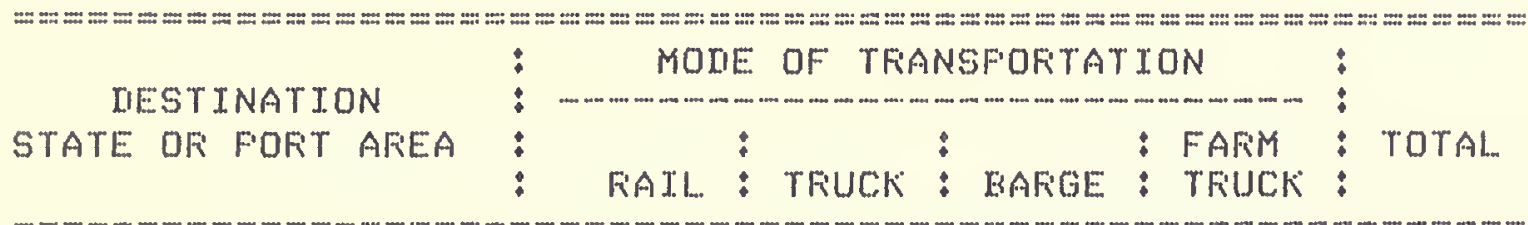

(THOUSANDS OF RUSHELS)

1100 MAFIYLANL

1400 NOFTH CAROLINA

1500 SOUTH CAFIOLINA

1609 GEOFGIA

1705 FLOFIIIIA

7202 SOUTH ATLANTIC:

TOTAL VOLUME

\begin{tabular}{rrrrr}
0 & 22 & 0 & 0 & 22 \\
4067 & 48841 & 0 & 0 & 52908 \\
4 & 1153 & 0 & 0 & 1157 \\
0 & 194 & 0 & 0 & 194 \\
709 & 352 & 0 & 0 & 1061 \\
1904 & 16034 & 2348 & 0 & 20286 \\
\hline 6684 & 66596 & 2348 & 0 & 75628
\end{tabular}


TABLE 145. 1977 COFN FECEIFTS FFOM UAFIIOUS OFIGINS BY FIFIMS IN AFEA 3200, NOFITH IIAKKOTA

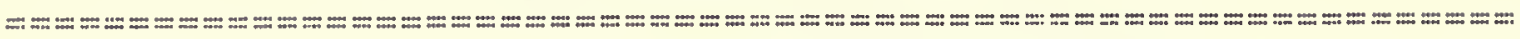

OFITINATING

STATE OFI FOFIT AFIEA
MOLE OF TFANSFOFTATIDN

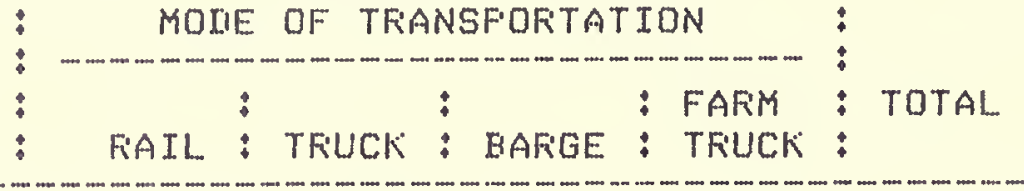

(THOUSANDIS OF BUSHELS)

2703 MINNESOTA

2704 MINNESOTA

\begin{tabular}{rrrrr}
1496 & 0 & 0 & 0 & 1496 \\
0 & 1100 & 0 & 0 & 1100 \\
\hline 1496 & 1100 & 0 & 0 & 2596
\end{tabular}

TOTAL VOLUME
1.977 COFIN SHIFMENTS TO UAFIQUS IIESTINATIONS BY

FIFIMS IN AFIEA 32.00, NOFTH IIAKIOTA

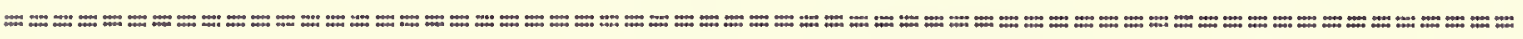

IIESTINATION

STATE OF FOFT AFEA
MOLIE OF TFIANSFORTATION

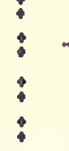

FAIL: TFUCK : BAFGE: FAFUMK :

TOTAL
2101 WISCONSIN

2701 MTNNESOTA

2705 MINNESOTA

2900 MISSOUFI

3502 KIANSAS

3900 WYOMTNG

4300 UTAH

7101 IIULUTH--SUFEFIOF

TOTAL VOLUME

(THOUSANIIS OF EUSHELS)

\begin{tabular}{rrrrr}
4867 & 0 & 0 & 0 & 4867 \\
0 & 20 & 0 & 0 & 20 \\
175 & 60 & 0 & 0 & 235 \\
527 & 0 & 0 & 0 & 527 \\
0 & 4 & 0 & 0 & 4 \\
500 & 0 & 0 & 0 & 500 \\
500 & 0 & 0 & 0 & 500 \\
208 & 40 & 0 & 0 & 248 \\
\hline 6777 & 124 & 0 & 0 & 6901
\end{tabular}

TAELE 147. 1977 COFIN FECEIFTS FFOM UAFIOUS OFIGINS BY FIFIMS IN AFIEA 182 I, OHIO

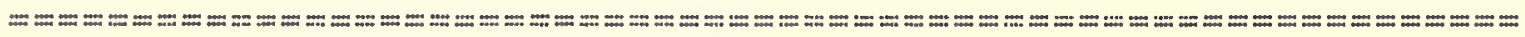

QFIGINATING

STATE DF FOFIT AREA
MOIIE OF TFANSFOFTATION

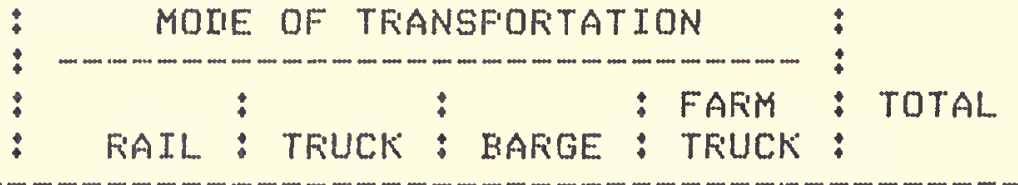

(THOUSANIIS OF EUSHELS)

\begin{tabular}{|c|c|c|c|c|c|c|}
\hline 1825 & OHIO & 624 & 33013 & 0 & 140331 & 173968 \\
\hline 1850 & DHIO & 0 & 3594 & 0 & 3305 & 6899 \\
\hline 1901 & INII I ANA & 0 & 56 & 0 & 0 & 56 \\
\hline 1902 & INII IANA & 0 & 10141 & $c$ & 8554 & 18695 \\
\hline 1903 & INII IANA & 0 & 194 & $c$ & 3926 & 4120 \\
\hline 2258 & ILLINOIS & 0 & 183 & $c$ & 0 & 183 \\
\hline 2319 & KENTUCKIY & 0 & 0 & $c$ & 747 & 747 \\
\hline
\end{tabular}


TABLE 148. 1977 COFN SHIFMENTS TO UAFIOUS IIESTINATTONS EY FIFMS IN AREA 1825, OHIO

\begin{tabular}{|c|c|c|c|c|c|c|}
\hline LESTINATION & MOIIE OF & $=$ OF TFIA & \multicolumn{2}{|c|}{ TFIANSFDFITATION } & \multirow{3}{*}{$\vdots$} & \multirow{3}{*}{ TOTAL } \\
\hline STATE OF FOFT AFEA & : & : & : & : FAFM & & \\
\hline & FiAIL. & TFUCK゙ & : EARGE & : TFIUCK & & \\
\hline & & (THOUSA & NIIS OF I & HUSHELS) & & \\
\hline 703 NEW YOFiK & 2000 & 0 & & 0 & 0 & 2000 \\
\hline 901 FENNSYLUANIA & 0 & 2191 & & 0 & 0 & 2191 \\
\hline 903 FEENSSYLUANIA & 2826 & 0 & & 0 & 0 & 2826 \\
\hline 1000 IIELAWAFIE & 0 & 105 & & 0 & 0 & 105 \\
\hline 1100 MAFIYLANII & 557 & 360 & & 0 & 0 & 917 \\
\hline WEST UIFGINIA & 1899 & 0 & & 0 & 0 & 1899 \\
\hline 1400 NDFITH CAFIOLINA & 12105 & 51 & & 0 & 0 & 12156 \\
\hline SOUTH CAFOLINA & 1. 4828 & 0 & & 0 & 0 & 14828 \\
\hline GEORGIA & 5000 & 0 & & 0 & 0 & 5000 \\
\hline OHIO & 624 & 3301.3 & & 0 & 0 & 33637 \\
\hline $1850 \quad 0 H I O$ & 7 & 1829 & & 0 & 0 & 1836 \\
\hline 1901 INIIANA & 0 & 40 & & 0 & 0 & 40 \\
\hline 1902 INIIIANA & 0 & 13 & & 0 & 0 & 13 \\
\hline 2319 KENTUCKKY & 0 & 2256 & & 0 & 0 & 2256 \\
\hline 2320 KEENTUCKY & 0 & 302 & & 0 & 0 & 302 \\
\hline 2410 TENNESSEE & 0 & 276 & & 0 & 0 & 276 \\
\hline TENNESSEE & 919 & 0 & & 0 & 0 & 919 \\
\hline 2502 MISSISSIFFI & 11 & 97 & & 0 & 0 & 108 \\
\hline 2608 ALABAMA & 0 & 0 & 257 & & 0 & 2574 \\
\hline 7103 TDLEIIO AFEA & 185 & 4634 & & 0 & 0 & 4819 \\
\hline 7201 NOFITH ATLANTIC & 19486 & 0 & & 0 & 0 & 19486 \\
\hline 7202 SOUTH ATLANTIC & 48758 & 561 & & 0 & 0 & 49319 \\
\hline 7302 LDUISIANA GULF & 0 & 0 & 2823 & & 0 & 28230 \\
\hline TOTAL VOLUME & 109205 & 45728 & 3080 & & 0 & 185737 \\
\hline
\end{tabular}

TABLE 149, 1977 COFN FECEIFTS FFOM UAFIOUS OFIGINS FY FIFMS IN AFEA 1850 , OHIO

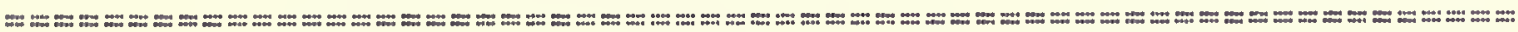

OFIIGINATING

STATE OFI FOFIT AFEA
MOIIE OF TFANSFOFTATION

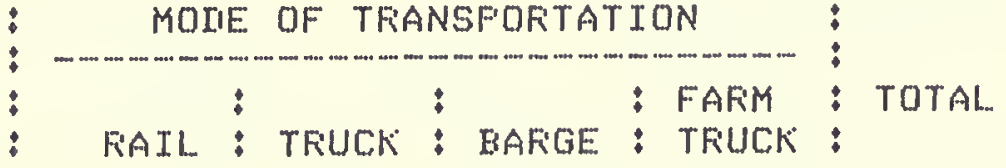

\begin{tabular}{|c|c|c|c|c|c|}
\hline & & THOUSANIIS OF & & AELSS & \\
\hline 1825 OHIO & 7 & 1829 & 0 & 9405 & 11241 \\
\hline 1850 OHIO & 5518 & 33133 & 0 & 79051 & 117703 \\
\hline 1901 INIIIANA & 0 & 400 & 0 & 367 & 767 \\
\hline 1902 INIIANA & 0 & 1250 & 0 & 0 & 1250 \\
\hline 2000 MICHIGAN & 0 & 5037 & 0 & 2873 & 7910 \\
\hline TOTAL VOLUME & 5526 & 41649 & 0 & 91696 & 138871 \\
\hline
\end{tabular}


TAKLE: 150, $19 \%$ COFN SHIFMENTS TO VAFIOUS INESTINATIONS EY FIFMS IN AFEA 1850 , OHIO

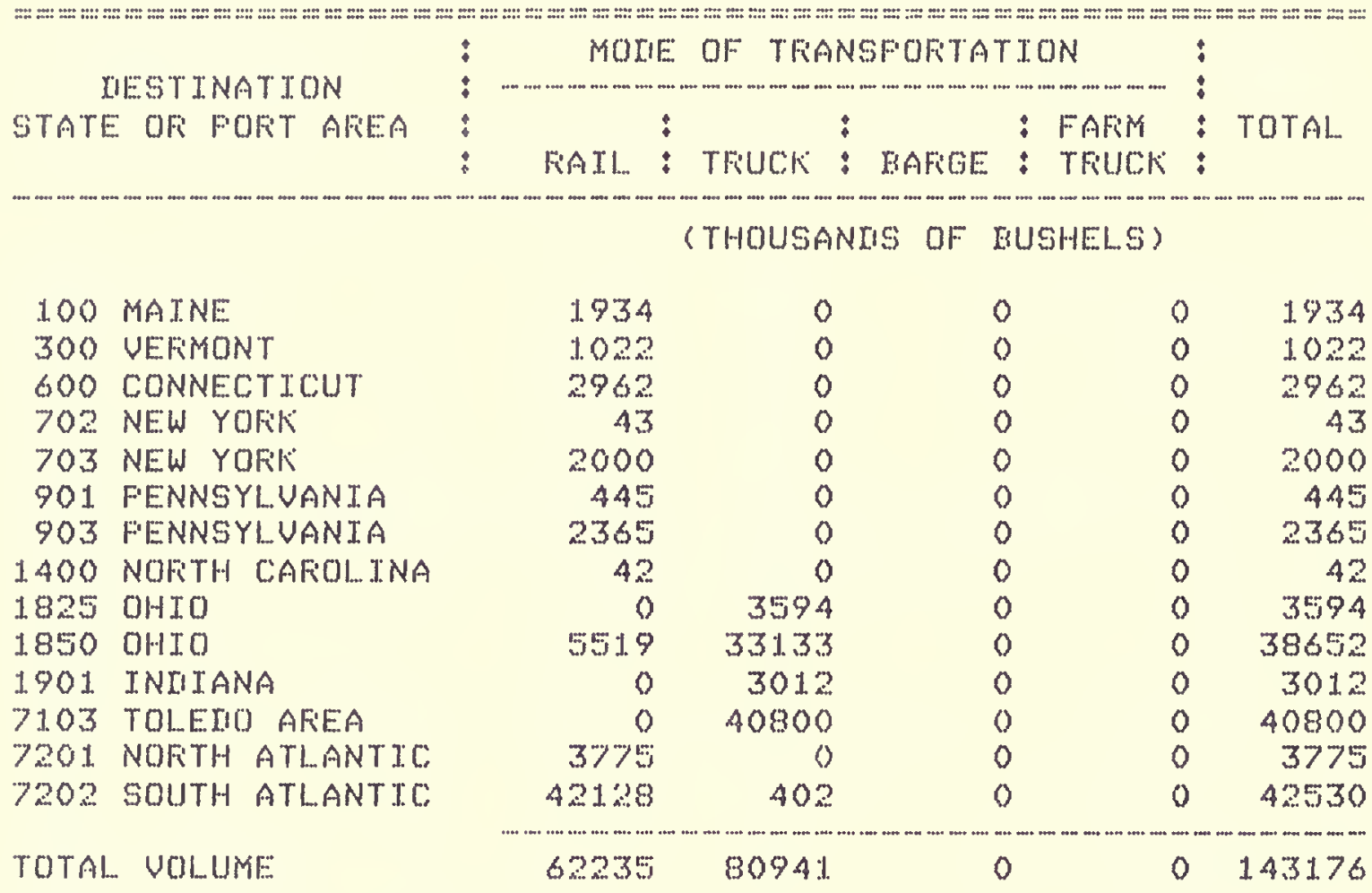

TAELE J51. 19\% COFN FECEIFTS FIOUM UAFIOUS OFIGTNS BY FIFIMS TN AFEA 3601 , OK゙I_AHOMA

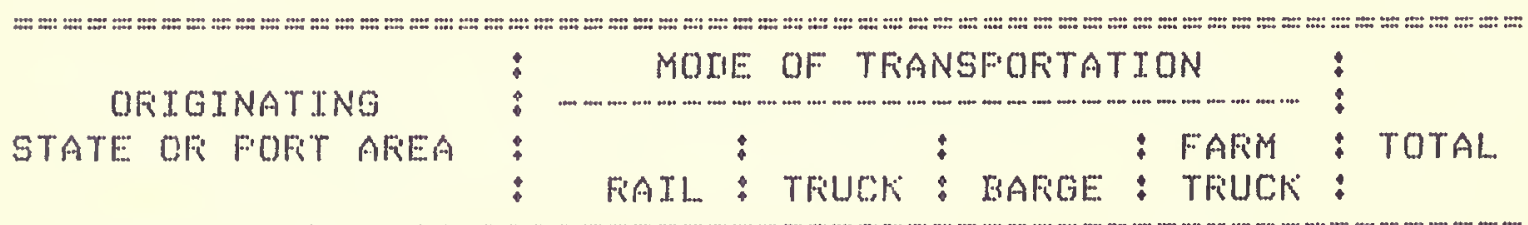

(THOUSANIIS OF EUSHELS)

$\begin{array}{llcccc}3401 \text { NEBFASKA } & 0 & 25 & 0 & 0 & 25 \\ 3601 \text { OKLAMOMA } & 0 & 0 & 0 & 5754 & 5754 \\ \text { TOTAL VOLLUME } & 0 & 25 & 0 & 5754 & 5799\end{array}$


TAELE 152,1977 COFN FECEIFTS FFOM UAFIOUS OFIGINS BY FIFMS IN AFEA 3602 , DKLLAHOMA

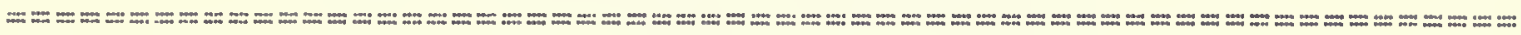

OFIGINATING

STATE OF FOFT AREA

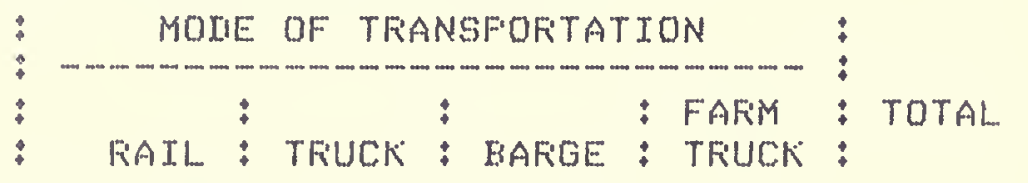

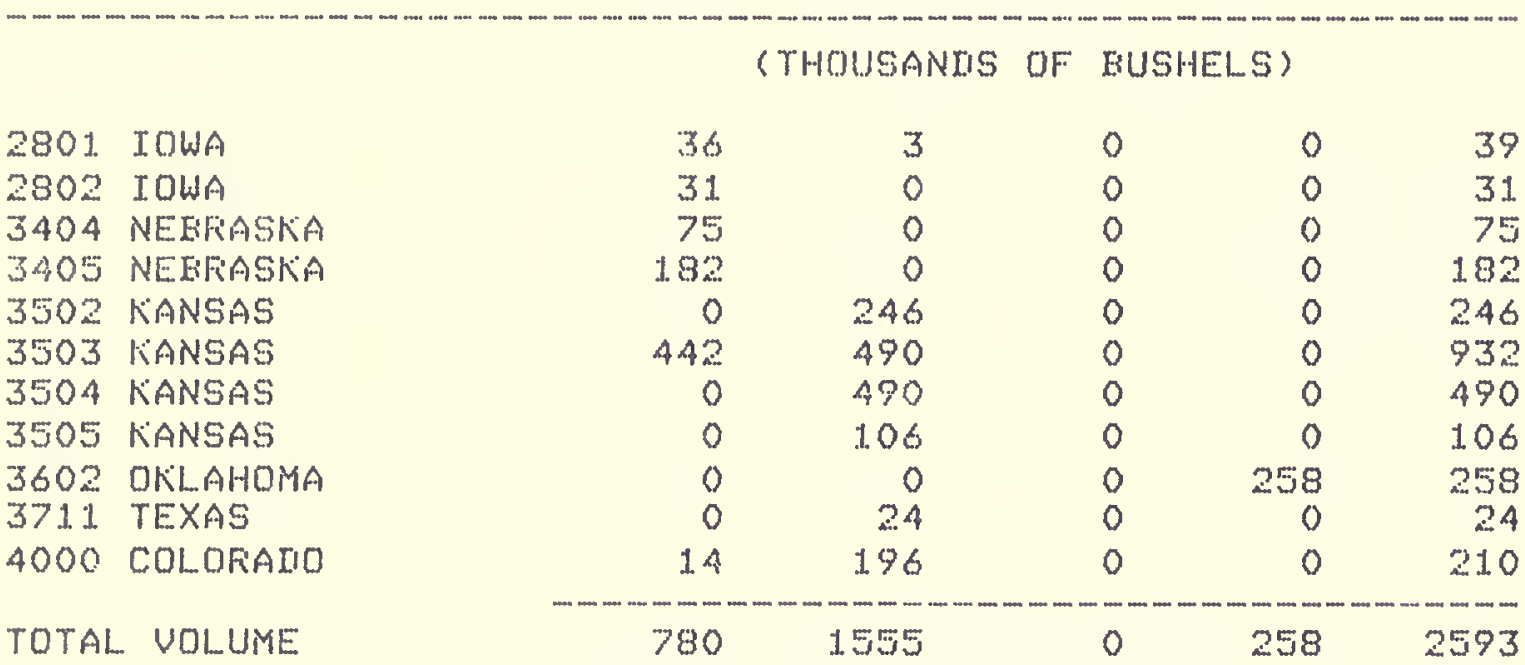

TAELE 193, 1977 COFN FECEIFTS FFOM UAFIIOUS OFIGINS BY FTFMS IN AFEA 3603 , OKLLAHOMA

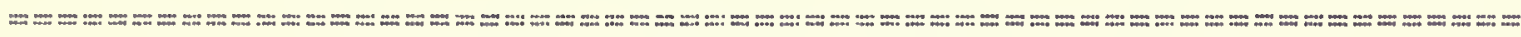

OFITINATING

STATE OF FURT AREA

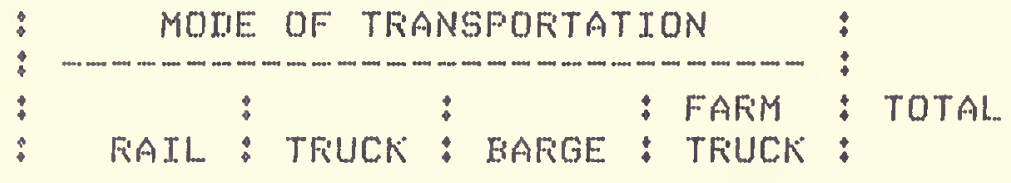

(THOUSANIS OF BUSHELS)
3603 DKLAHOMA

TOTAL. VOLUME

\begin{tabular}{ccccc}
0 & 0 & 0 & 188 & 188 \\
\hline 0 & 0 & 0 & 188 & 188
\end{tabular}

TAELE 154, 1977 COFN SHIFMENTS TO VAFIOUS IIESTINATIONS BY FIFMS IN AFEA 3603 , OKLAHOMA

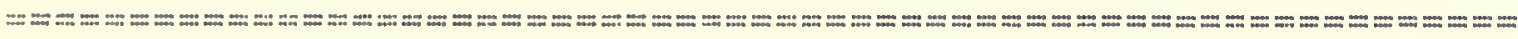

IIESTINATION

STATE OFI FOFIT AFEEA

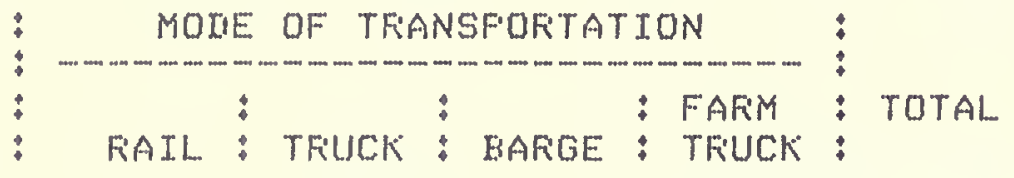

(THOUSANDIS OF EUSHELS)
3711 TEXAS

TOTAL VOLUME

\begin{tabular}{ccccc}
0 & 780 & 0 & 0 & 780 \\
\hline 0 & 780 & 0 & 0 & 780
\end{tabular}




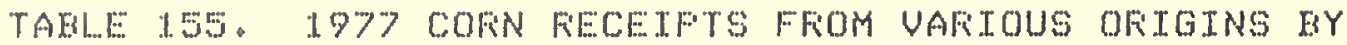
FTFMS IN AFENA 3604 y OKLAHOMA

.

OHITINATINO

STATE OF: FOFT AFI:
MOTIE OF TFANSFOFITATION

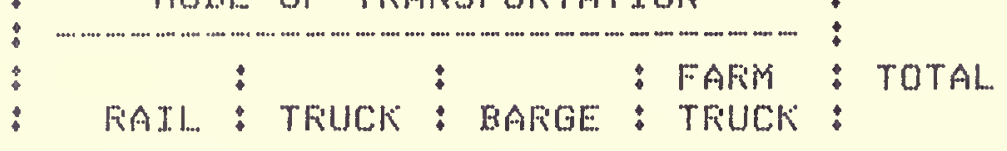

(THOUSANIS OF EUSHELS)

\begin{tabular}{|c|c|c|c|c|c|}
\hline 2801 IOWA & 27.4 & 0 & 0 & 0 & 274 \\
\hline 2802 IOWA & 66 & 0 & 0 & 0 & 66 \\
\hline MT.5soumt & 524 & 156 & 0 & 0 & 680 \\
\hline NEEFASKA & 20 & 736 & 0 & 0 & 756 \\
\hline NEBFASI゙A & 448 & 1159 & 0 & 0 & 1607 \\
\hline K゙ANSAS & 1.331. & 0 & 0 & 0 & 1331 \\
\hline 3604 OKLLAHOMA & 0 & 0 & 0 & 806 & 806 \\
\hline OTAL & 2663 & 2051 & 0 & 806 & $5=20$ \\
\hline
\end{tabular}

TAELE: 156.1977 COFN SHIFMENTS TO UAFIOUS IIESTINATIONS EY FIVMS TN AFI::.: 3604 Y OKILAHOMA

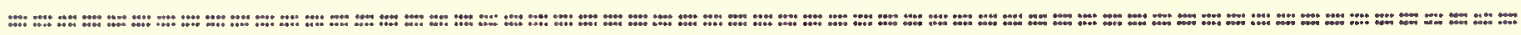

MESTINATTON

STATE OF WORT AKEA
MOIE: OF TFANSFORTATION

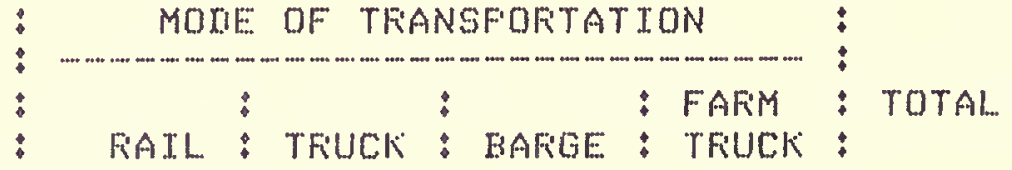

(THCUSANDS OF BUSHELS)

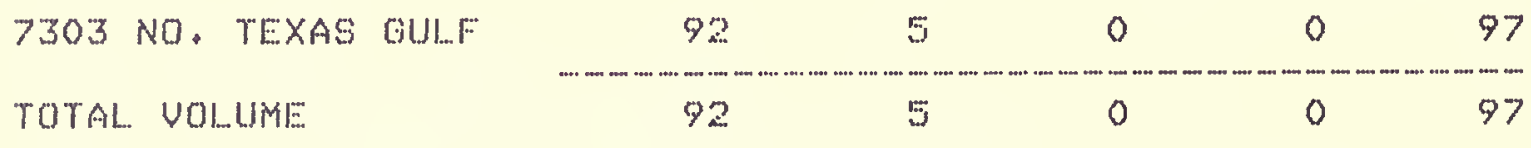

TAKIE: 157. 1977 COFN WECETFTS FFOM UAFIOUS OFITGING EY FIFIS IN AFI:EA 460OY OFEGON

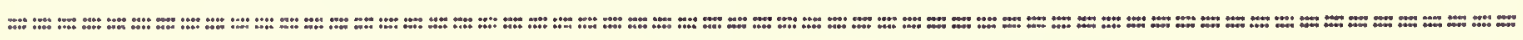

OFITGTINATTING

STATE OFI FOFT AFEA
MOIE DF TFANSFOFTATION

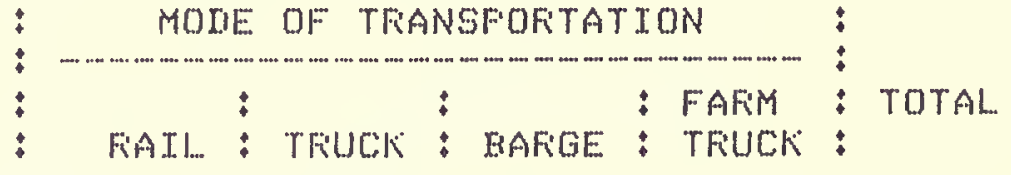

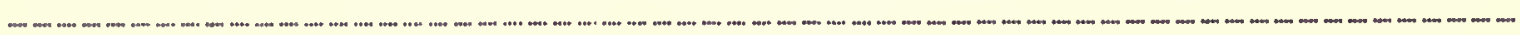

(THOUSANDS OF BUSHELS)

2704 MINNESOTA

2705 MTNNESOTA

3301 SOUTH DAKKOTA

3302 SOUTH IIAKOTA

3404 NEEFIASKIA

3502 KNANSAS

$\begin{array}{rrrrr}1605 & 0 & 0 & 0 & 1605 \\ 2366 & 0 & 0 & 0 & 2366 \\ 0 & 64 & 0 & 0 & 64 \\ 64 & 13 & 0 & 0 & 77 \\ 1415 & 0 & 0 & 0 & 1415 \\ 147 & 0 & 0 & 0 & 147 \\ 5597 & 77 & 0 & 0 & 5674\end{array}$


TAELE 158. 1977 COFN FECETFTS FFOM UAFIOUS OFIGINS BY FIFMS IN AREA 901 , FENNSYLUANIA

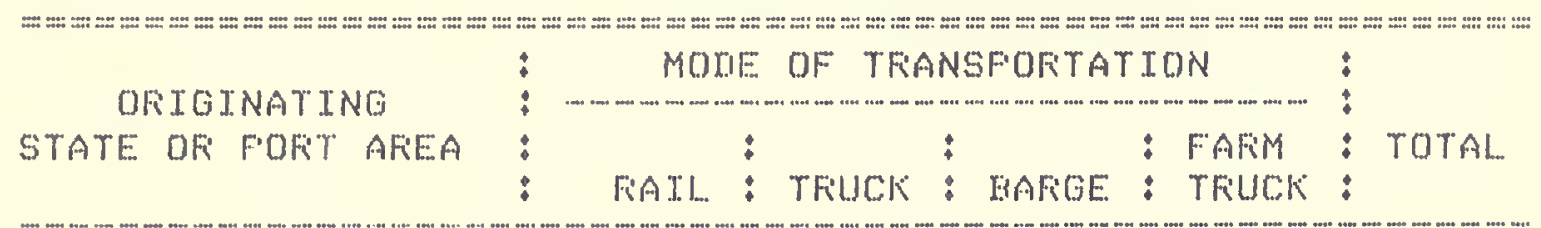

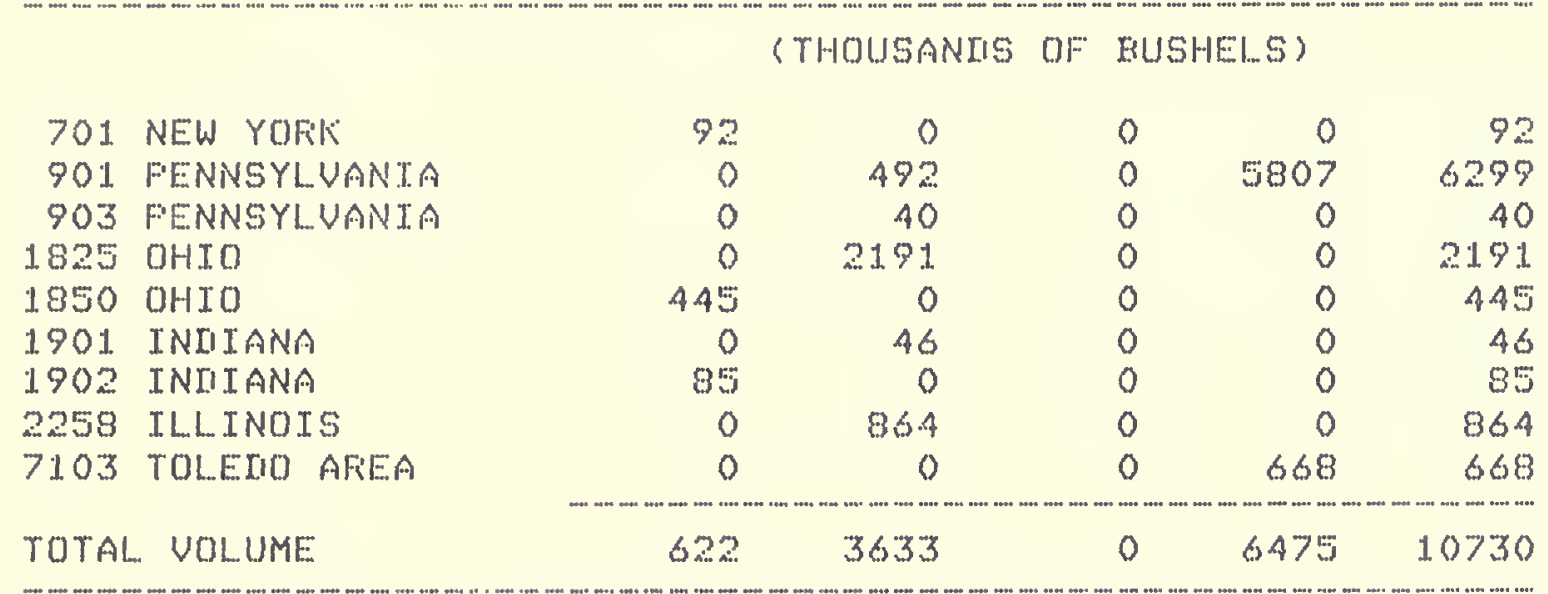

TAEIE 159. 1977 COFN SHIFMENTS TO VAFIOUS DESTINATIONS BY FIHMS IN AREA 901 , FENNSYLUANIA

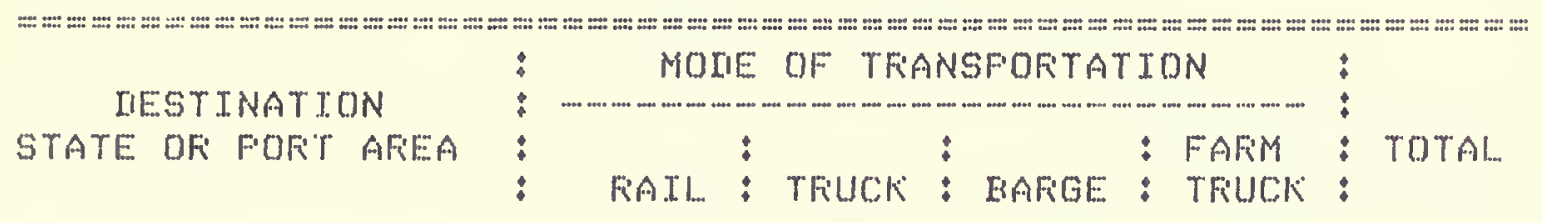

$\begin{array}{llcccc} & \text { (THOUSANIS DF BUSHELS) } \\ 100 \text { MAINE } & 21 & 0 & 0 & 0 & 21 \\ 200 \text { NEW HAMFSHIFE } & 64 & 0 & 0 & 0 & 64 \\ 300 \text { UEFMONT } & 87 & 0 & 0 & 0 & 87 \\ 701 \text { NEW YOFK } & 79 & 86 & 0 & 0 & 165 \\ 901 \text { FENNSYLVANIA } & 0 & 492 & 0 & 0 & 492 \\ 903 \text { FENNSYLVANIA } & 0 & 1452 & 0 & 0 & 1452 \\ \text { TOTAL VOLUME } & 251 & 2030 & 0 & 0 & 2281\end{array}$


TABLE 160. 1977 COFN FECEIFTS FFOM UARIOUS OFIGINS EY FIFMS IT AFEA 902, FENNSYLUANIA

OFIGINATING
$\begin{aligned} & \text { OFI } \\ & \text { STATE OFI FOFT AFEA }\end{aligned}$

(THOUSANIS OF RUSHELS)

701. NEW YOFK

902 FENNGYLUANTA

903 FENNSYLUANIA

TOTAL VOLLIME

\begin{tabular}{rrrrr}
0 & 31 & 0 & 2008 & 2039 \\
0 & 158 & 0 & 3331 & 3489 \\
0 & 1257 & 0 & 0 & 1257 \\
\hline 0 & 1446 & 0 & 5339 & 6785
\end{tabular}

TAELE 161. 1977 COFN SHIFMENTS TO UAFIIOUS IIESTINATIONS BY FIFMS IN AFEA 902, FENNSYLUANTA

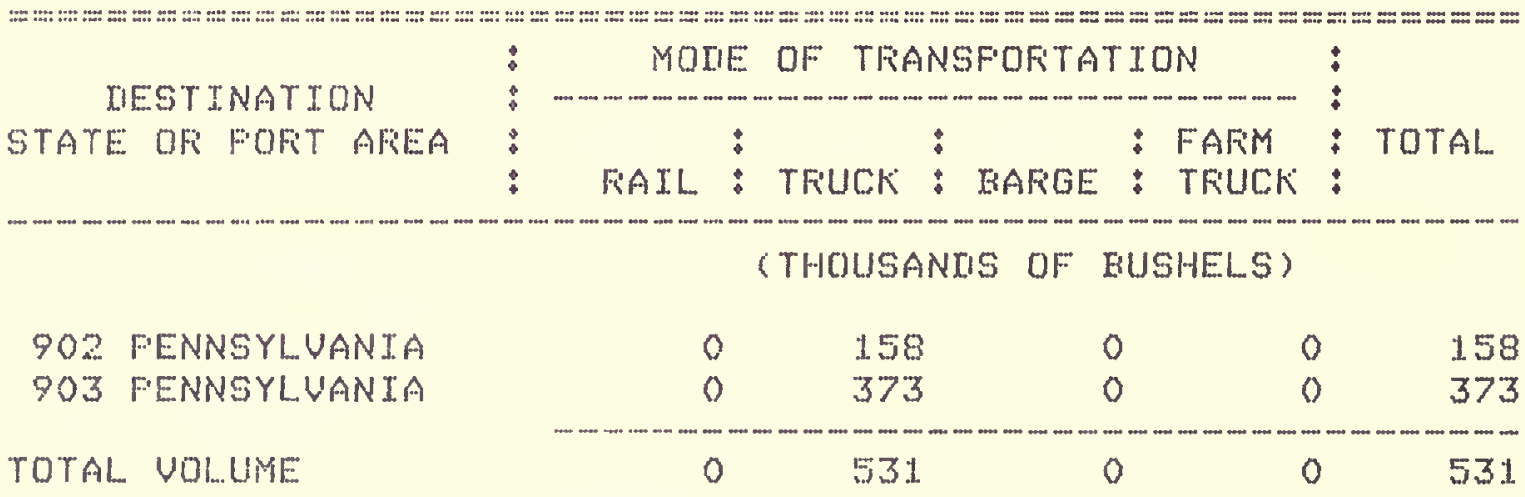

TOTAL VOL LME 
TALLE 162, 1977 COFIN FECEETFTS FFOM UAFIOUS OFIGINS BY

FIFIMS IN AFEA 903 \% FENNSYI.. WANTA

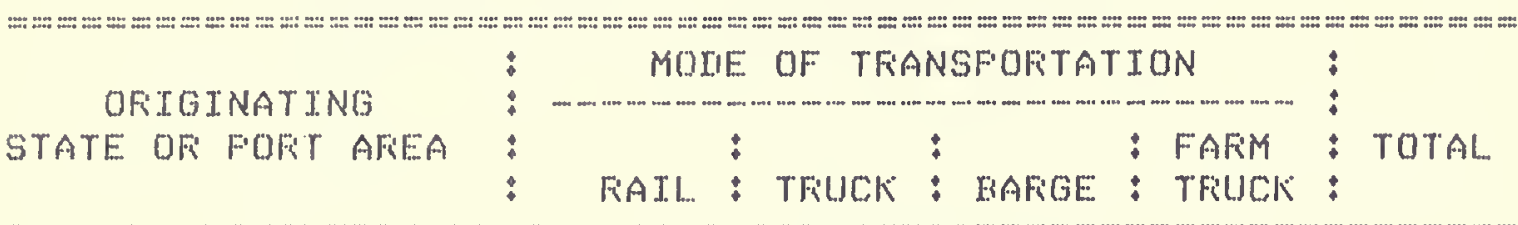

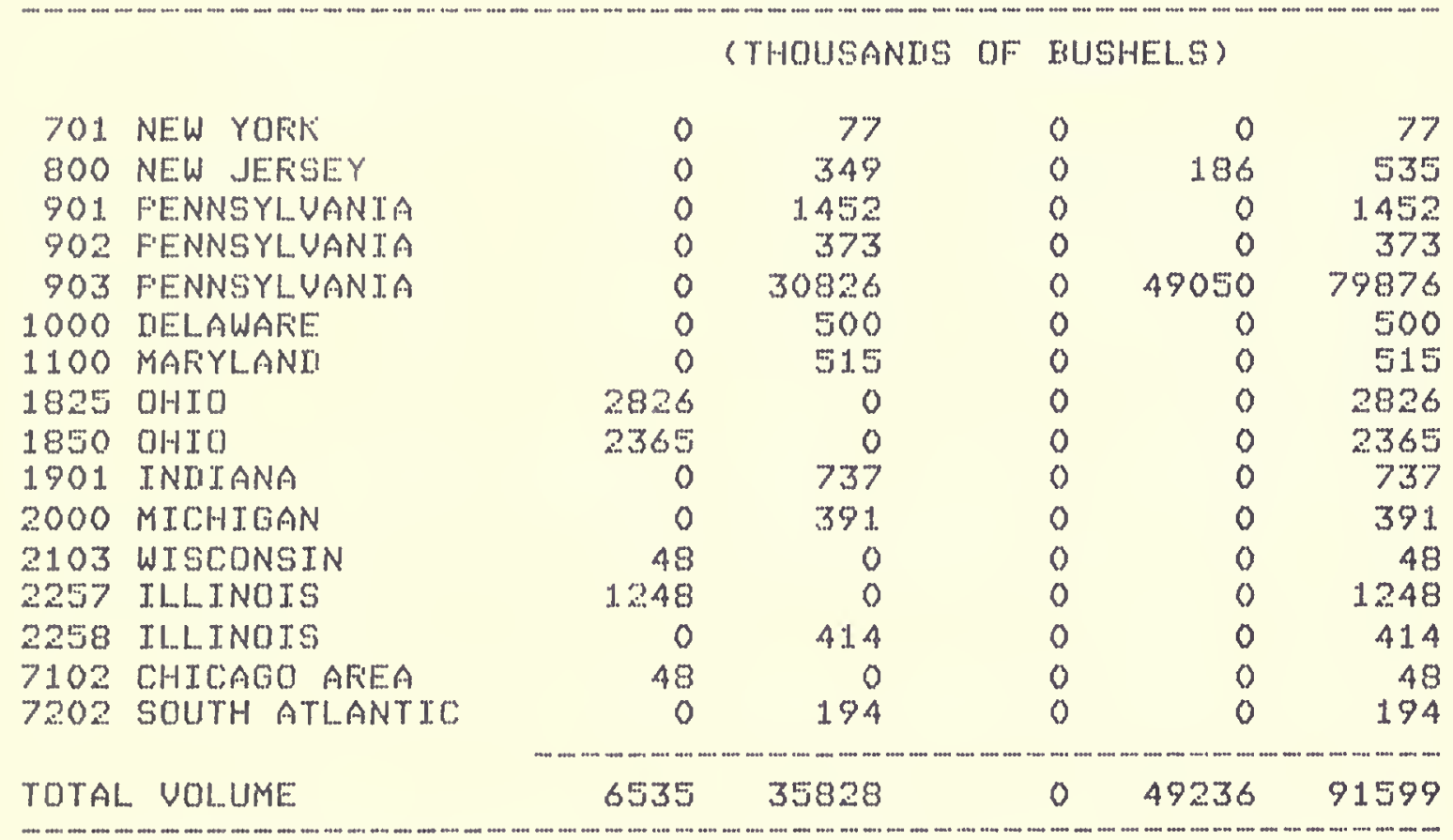

TABLE 163. 1977 COFN SHIFMENTS TO UAFIOUS IIESTINATIONS BY FIEMS IN AFEA 903, FENNSYLUANIA

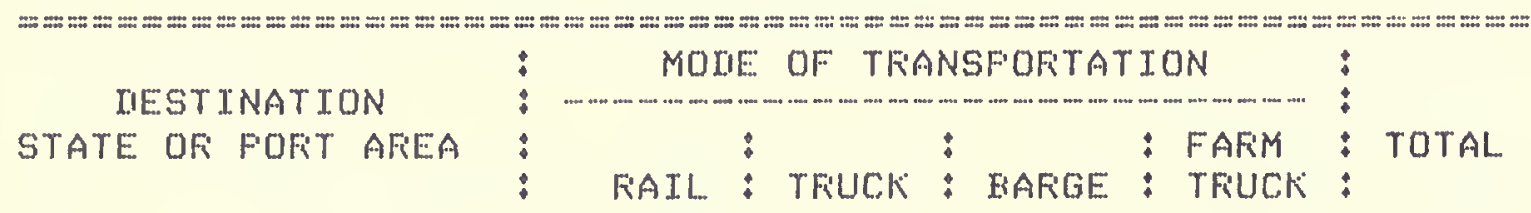

(THOUSANLIS OF RUSHELS)

$\begin{array}{lrrrrr}100 \text { MAINE } & 7 & 0 & 0 & 0 & 7 \\ 200 \text { NEW HAMFSHIFE } & 14 & 0 & 0 & 0 & 14 \\ 300 \text { UEFIONT } & 1 & 16 & 0 & 0 & 17 \\ 701 \text { NEW YOFK } & 18 & 209 & 0 & 0 & 227 \\ 703 \text { NEW YOFK } & 0 & 75 & 0 & 0 & 75 \\ 800 \text { NEW JEFSEY } & 0 & 132 & 0 & 0 & 132 \\ 901 \text { FENNSYLVANIA } & 0 & 40 & 0 & 0 & 40 \\ 902 \text { FENNSYLUANIA } & 0 & 1257 & 0 & 0 & 1257 \\ 903 \text { FENNSYLUANIA } & 0 & 30826 & 0 & 0 & 30826 \\ 1000 \text { DELAWAFE } & 0 & 250 & 0 & 0 & 250 \\ 1100 \text { MAFYLAND } & 0 & 1809 & 0 & 0 & 1809 \\ 1200 \text { UIFGINIA } & 0 & 36 & 0 & 0 & 36 \\ 7201 \text { NOFTH ATLANTIC } & 0 & 1170 & 0 & 0 & 1170 \\ 7202 \text { SOUTH ATLANTIC } & 0 & 1197 & 0 & 0 & 1197 \\ \text { TOTAL WOLUME } & 40 & 37017 & 0 & 0 & 37057\end{array}$


TALHE 164. I.977 COFN FECEIFTS FFOM UARIOUS OFIGINS RY FTFMS TN AFI:EA TEOO Y SOUTH CAROLINA

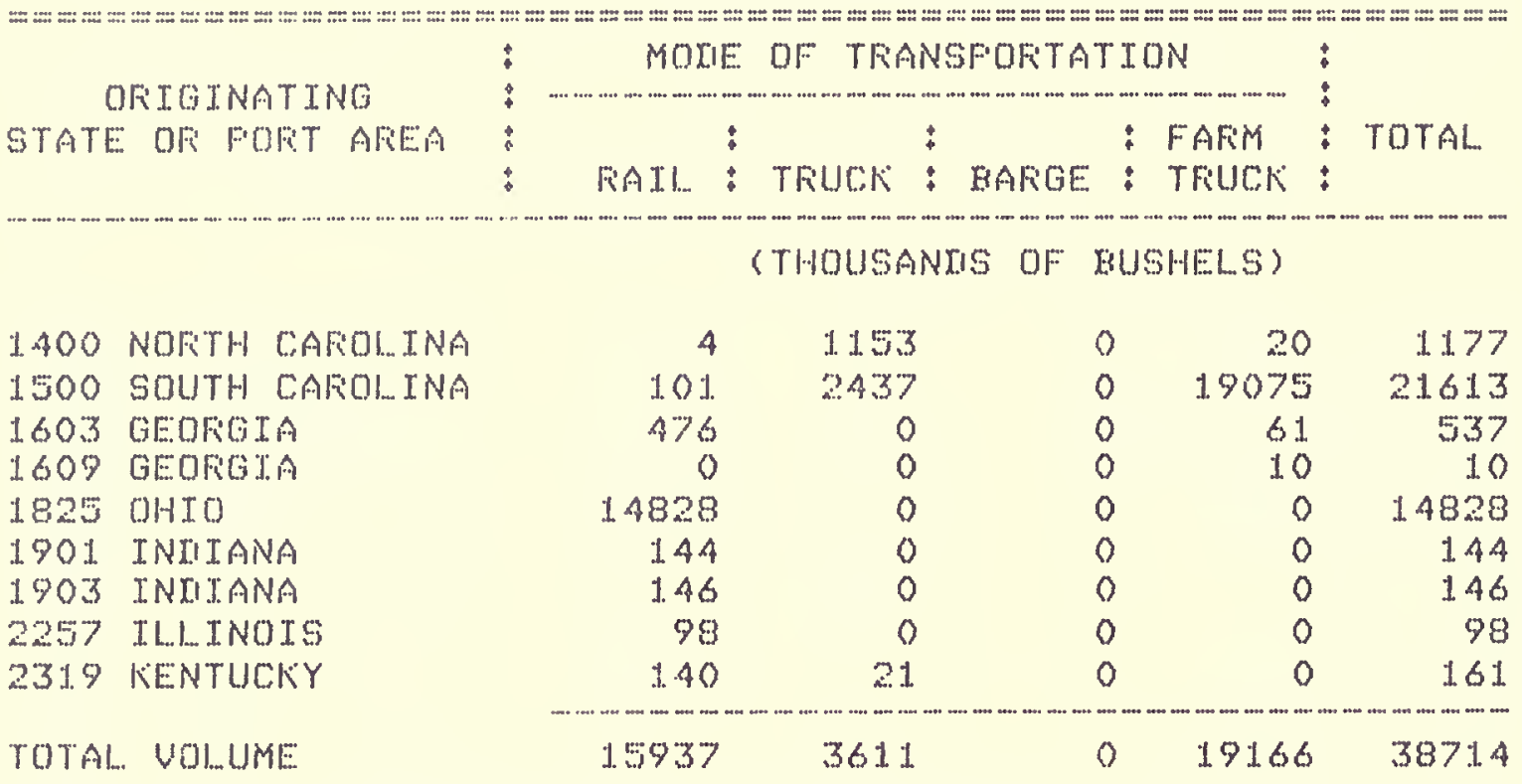

TABUE 165. 1977 COFN SHTFMENTS TO VAFIOUS CIESTINATTONS BY FIFMS TN AREA IEOOY SOUTH CAROLTNA

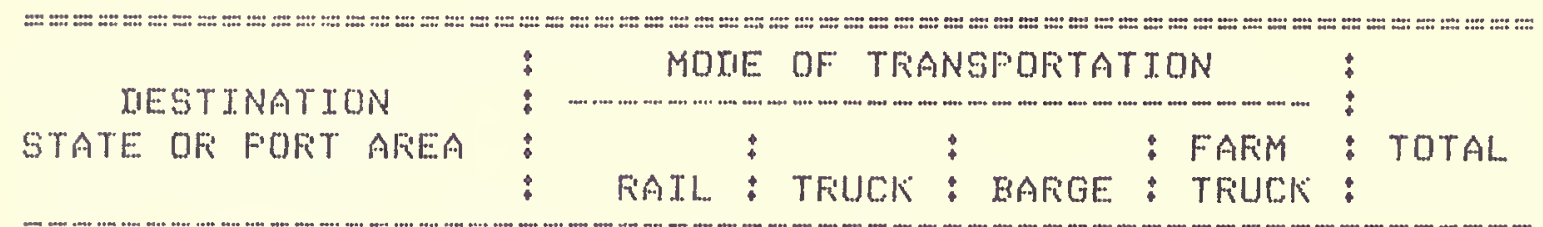

(THOUSANDS OF RUSHELS)

\begin{tabular}{|c|c|c|c|c|c|c|}
\hline 1200 & UIFGTNIA & 805 & 0 & 0 & 0 & 805 \\
\hline 1300 & WEST UIFGINTA & 80 & 20 & 0 & 0 & 100 \\
\hline 1400 & NOFTH CAFOL INA & 36 & 792 & 0 & 0 & 828 \\
\hline 1500 & SOUTH CAROL INA & 101 & 2437 & 0 & 3422 & 5960 \\
\hline 1603 & GEOFGIA & 111 & 199 & 0 & 0 & 310 \\
\hline 1609 & GEOFGIA & 0 & 0 & 0 & 44 & 44 \\
\hline 1703 & FLOFIIIIA & 540 & 0 & 0 & 0 & 540 \\
\hline 7202 & SOUTH ATL..ANTIC. & 1129 & 3225 & 0 & 0 & 4354 \\
\hline $\mathrm{TAL}$ & VOL..UME & 2802 & 6673 & 0 & 3466 & 12941 \\
\hline
\end{tabular}


TABLE 166. 1977 COFN FECETFTS FFOM UAFIOUS OFIGINS EY

FIFIMS IN AFEEA 3301, SOUTH IIAKOOTA

훌

DFITIINATTNG

STATE OF FOFT AFEA
MODE OF TFANSFOFITATION

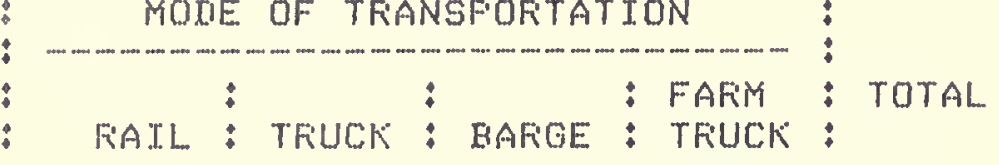

(THOUSANIIS OF EUSHELS)

2703 MINNESOTA

2704 MINNESOTA

2705 MINNESOTA

3301 SOUTH IIAKOTTA

TOTAL VOLUME

\begin{tabular}{rrrrr}
0 & 2559 & 0 & 0 & 2559 \\
0 & 2143 & 0 & 0 & 2143 \\
208 & 0 & 0 & 0 & 208 \\
0 & 0 & 0 & 4981 & 4981 \\
\hline 208 & 4702 & 0 & 4981 & 9891
\end{tabular}

TAELE 167. 1977 COFIN SHIFMENTS TO UAFIOUS IIESTINATIONS BY FIFIMS IN AFEA 3301, SOUTH IAKOTA

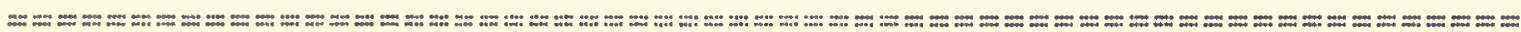

IIESTINATTON

STATE OF FOFT AFEA

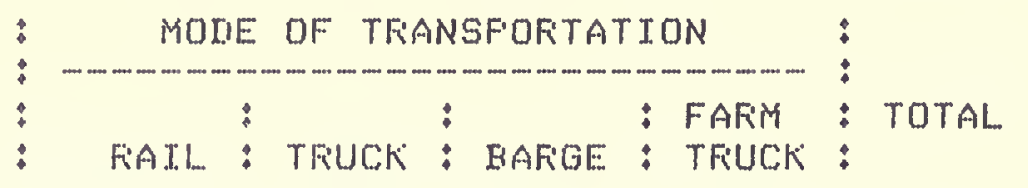

(THOUSANIS OF BUSHELS)

2703 MINNESOTA

2704 MINNESOTA

2705 MINNESOTA

2801 IOWA

3403 NEEFIASKIA

3502 KIANSAS

3505 KIANSAS

4600 DFEGON

7101 IIULUTH-SUFEFIOF

7303 NO. TEXAS GULF

7401 COLUMETA RIVEF

TOTAL VOLUME

$\begin{array}{rrrrr}0 & 1872 & 0 & 0 & 1872 \\ 0 & 379 & 0 & 0 & 379 \\ 487 & 634 & 0 & 0 & 1121 \\ 88 & 179 & 0 & 0 & 267 \\ 92 & 312 & 0 & 0 & 404 \\ 0 & 4 & 0 & 0 & 4 \\ 40 & 0 & 0 & 0 & 40 \\ 0 & 64 & 0 & 0 & 64 \\ 654 & 73 & 0 & 0 & 727 \\ 60 & 29 & 0 & 0 & 89 \\ 322 & 0 & 0 & 0 & 322 \\ 1743 & 3546 & 0 & 0 & 5289\end{array}$

TABLE 168. 1977 COFN FECEIFTS FROM UAFIOUS OFIGINS EY

FIFMS IN AFEA 3302, SOUTH IIAKOTA

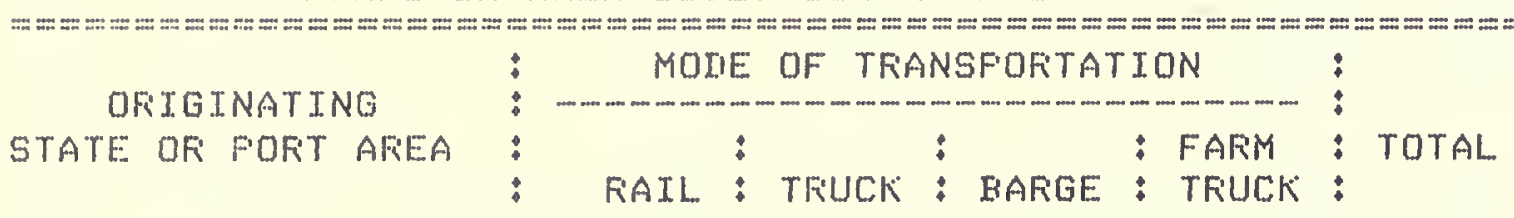

(THOUSANIIS OF EUSHELS)

3302 SOUTH IIAKOOTA

TOTAL VOLUME

$\begin{array}{ccccc}0 & 0 & 0 & 3959 & 3959 \\ 0 & 0 & 0 & 3959 & 3959\end{array}$


TARLE 169. 1977 COFN SHIFMENTS TO VAFIDUS IIESTINATIONS BY FIFMS IN AREA 3302, SOUTH IIAKOTA

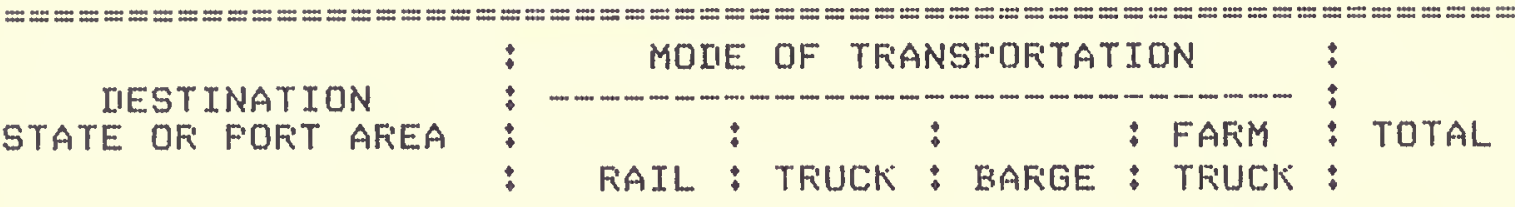

(THOUSANDS OF EUSHELS)

2801 IOWA

4600 OREGON

7303 NO. TEXAS GULF

7402 FUGET SOUNI

TOTAL VOLUME

\begin{tabular}{rrrrr}
19 & 586 & 0 & 0 & 605 \\
64 & 13 & 0 & 0 & 77 \\
323 & 192 & 0 & 0 & 515 \\
136 & 0 & 0 & 0 & 136 \\
\hline 542 & 791 & 0 & 0 & 1333
\end{tabular}

TABLE 170, 1977 COFN RECEIFTS FFOM UARIOUS OFIGINS BY FIFISS IN AREA 2410, TENNESSEE

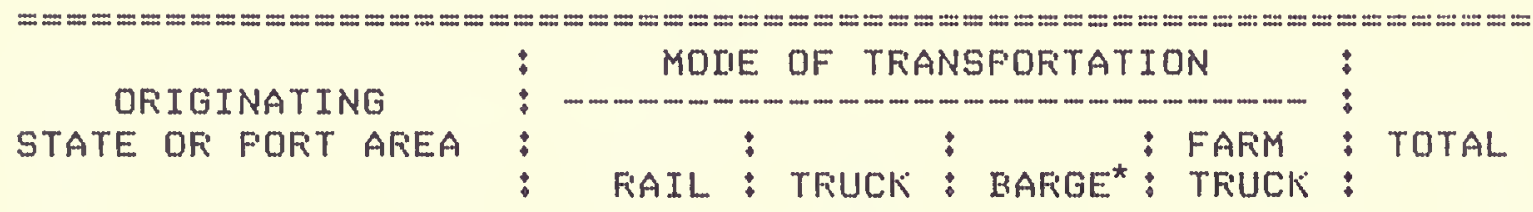

(THOUSANIS OF EUSHELS)

\begin{tabular}{|c|c|c|c|c|c|c|}
\hline 1825 & OHID & 0 & 276 & 0 & 0 & 276 \\
\hline 1901 & INII ANA & 155 & 0 & 0 & 0 & 155 \\
\hline 1902 & INII ANA & 471 & 90 & 0 & 0 & 561 \\
\hline 1903 & INIIANA & 1917 & 0 & 0 & 0 & 1917 \\
\hline 2257 & ILLINOIS & 2728 & 0 & 0 & 0 & 2728 \\
\hline 2318 & KENTUCKY & 3497 & 684 & 0 & 0 & 4181 \\
\hline 2410 & TENNESSEE & 0 & 1704 & 0 & 1613 & 3317 \\
\hline 2411 & TENNESSEE & 265 & 152 & 0 & 0 & 417 \\
\hline 2412 & TENNESSEE & 100 & 0 & 0 & 0 & 100 \\
\hline 2608 & ALABAMA & 50 & 0 & 0 & 0 & 50 \\
\hline 2705 & MINNESDTA & 549 & 0 & 0 & 0 & 549 \\
\hline 2803 & IOWA & 50 & 0 & 0 & 0 & 50 \\
\hline 2900 & MISSOURI & 372 & 0 & 0 & 0 & 372 \\
\hline
\end{tabular}

*FECEIFTS EY BAFGE ARE INCLUIIEI WITH FECEIFTS BY FAIL TO AVOII IISCLOSURE OF INIIUIIIUAL FIFIM OFEFATIONS. 
TAELE 17\%. 1977 COFN SHIFMENTS TO VAFIOUS IIESTINATTONS BY FTEMS IN AREA 2A10, TENNESSSEE

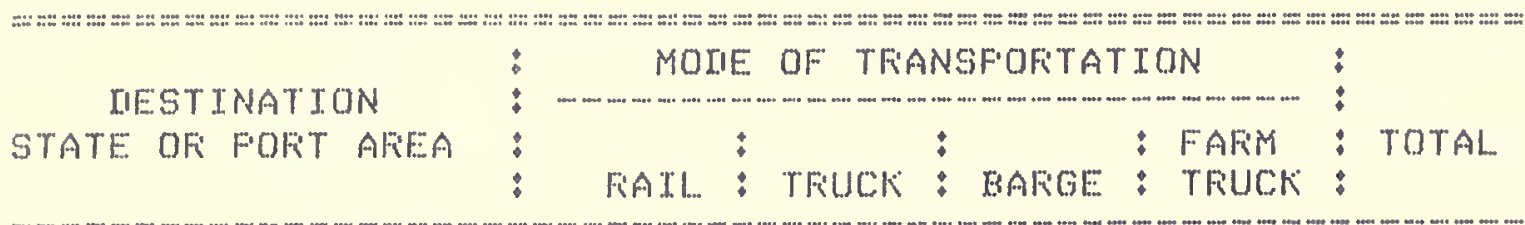

(THOUSANDIS OF RUSHELS)

$\begin{array}{lrrrrr}1200 \text { UTFISINIA } & 0 & 3 & 0 & 0 & 3 \\ 1603 \text { GEQFGIA } & 0 & 125 & 0 & 0 & 125 \\ 1701 \text { FLOFIIIA } & 01 & 0 & 0 & 0 & 51 \\ 2410 \text { TENNESSEE } & 0 & 1704 & 0 & 750 & 2454 \\ 2607 \text { ALABAMA } & 0 & 68 & 0 & 0 & 68 \\ 2608 \text { ALAEAMA } & 0 & 376 & 0 & 0 & 376 \\ \text { TOTAL UOLUME } & 51 & 2276 & 0 & 750 & 3077\end{array}$

TABLE 172. 197\% COFIN RECETFTS FFOM UAFIOUS OFIGINS BY FTIMS TN AREA 2A11, TENNESSEE

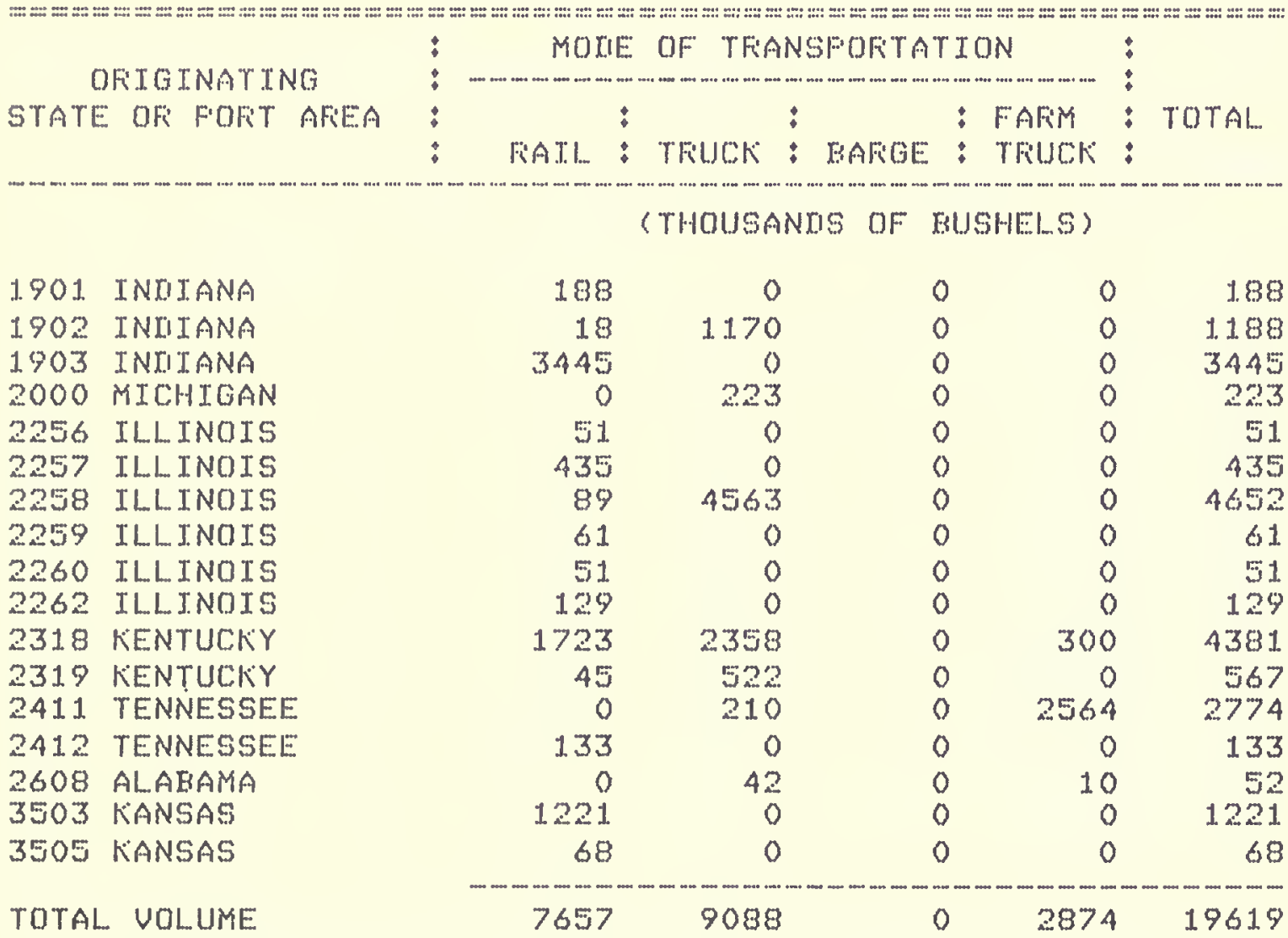


TABLE 173. 1977 COFN SHIFMENTS TO VARIOUS IIESTINATIONS BY FIRMS IN AFEA 2411, TENNESSEE

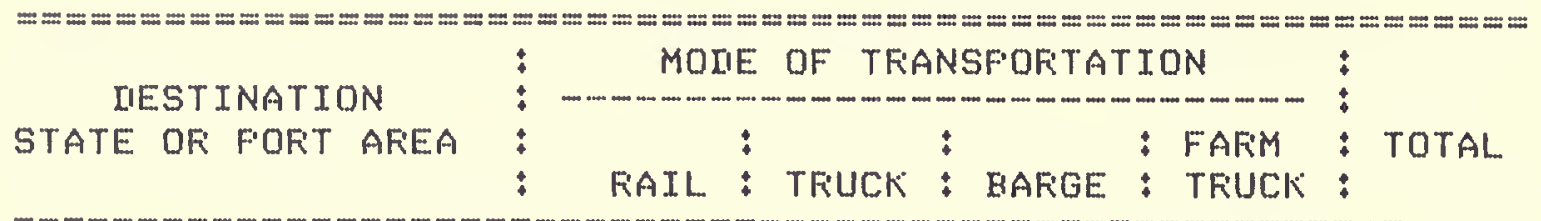

(THOUSANLIS OF EUSHELS)

$\begin{array}{llrrrrr}1609 & \text { GEOFGIA } & 210 & 96 & 0 & 0 & 306 \\ 2318 \text { KNENTUCKY } & 0 & 785 & 0 & 0 & 785 \\ 2410 \text { TENNESSEE } & 265 & 152 & 0 & 0 & 417 \\ 2411 \text { TENNESSEE } & 0 & 210 & 0 & 250 & 460 \\ 2412 \text { TENNESSEE } & 165 & 3171 & 0 & 0 & 3336 \\ 2608 \text { ALABAMA } & 0 & 87 & 0 & 0 & 87 \\ \text { TOTAL VOLUME } & 640 & 4501 & 0 & 250 & 5391\end{array}$

TAELE 174. 1977 COFIN FECEIFTS FFOM UAFIOUS OFIGINS BY FIFIMS IN AREA 2412, TENNESSEE

\begin{tabular}{|c|c|c|c|c|c|c|c|c|}
\hline \multicolumn{2}{|c|}{ OFIGINATING } & \multirow{3}{*}{$\begin{array}{l}\vdots \\
\vdots \\
\vdots\end{array}$} & MONE OF & IE OF TRA & \multicolumn{3}{|c|}{ TRANSFOFTATION } & \multirow{3}{*}{ TOTAL. } \\
\hline STATE & E OR FORIT AFIEA & & & : & $:$ & : & FARM & \\
\hline & & & FAIL & : TFUCK & : BARGE & * : & TFUCK & \\
\hline & & & \multicolumn{3}{|c|}{ (THOUSANIIS OF } & \multicolumn{2}{|c|}{ BUSHELS } & \\
\hline 1603 & \multicolumn{2}{|l|}{ GEOFIGIA } & 0 & \multicolumn{2}{|c|}{141} & 0 & 0 & 141 \\
\hline 1825 & OHIO & & 919 & \multicolumn{2}{|c|}{0} & 0 & 0 & 919 \\
\hline 1902 & INIIIANA & & 0 & \multirow{2}{*}{\multicolumn{2}{|c|}{$\begin{array}{r}190 \\
0\end{array}$}} & 0 & 0 & 190 \\
\hline 1903 & INIIIANA & & 3306 & & & 0 & 0 & 3306 \\
\hline 2256 & ILLINOIS & & 150 & \multicolumn{2}{|c|}{0} & 0 & 0 & 150 \\
\hline $\begin{array}{l}2257 \\
2258\end{array}$ & $\begin{array}{l}\text { ILLINOIS } \\
\text { ILLINOIS }\end{array}$ & & $\begin{array}{r}1466 \\
0\end{array}$ & \multicolumn{2}{|c|}{$\begin{array}{r}0 \\
1521\end{array}$} & $\begin{array}{l}0 \\
0\end{array}$ & $\begin{array}{l}0 \\
0\end{array}$ & $\begin{array}{l}1466 \\
1521\end{array}$ \\
\hline 2262 & ILLINOIS & & 3986 & \multicolumn{2}{|l|}{0} & 0 & 0 & 3986 \\
\hline 2318 & K゙ENTUCKKY & & 1833 & \multicolumn{2}{|l|}{1752} & 0 & 76 & 3661 \\
\hline 2411 & TENNESSEE & & 165 & \multicolumn{2}{|c|}{3171} & 0 & 0 & 3336 \\
\hline 2412 & TENNESSEE & & 100 & \multicolumn{2}{|c|}{5030} & 0 & 11757 & 16887 \\
\hline 2502 & MISSISSIFFI & & 0 & \multicolumn{2}{|c|}{134} & 0 & 80 & 214 \\
\hline 2803 & IOWA & & 38 & \multicolumn{2}{|c|}{0} & 0 & 0 & 38 \\
\hline 3038 & AFKKANSAS & & 0 & \multicolumn{2}{|c|}{0} & 0 & 173 & 173 \\
\hline 3404 & NEEFIASKKA & & 3 & \multicolumn{2}{|c|}{0} & 0 & 0 & 3 \\
\hline \multicolumn{2}{|c|}{ TOTAL VOLUME } & & 11966 & \multicolumn{2}{|l|}{11939} & 0 & 12086 & 35991 \\
\hline
\end{tabular}

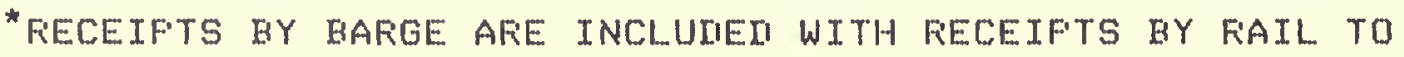
AVOII IISCLOSUFE OF INIIUITIUAL FIFM OFEFATIONS. 
TABLE 175, 1977 COFN SHIFMENTS TO UAFITUS IIESTINATIONS BY FIFMS JN AFEA 24I2, TENNESSEE

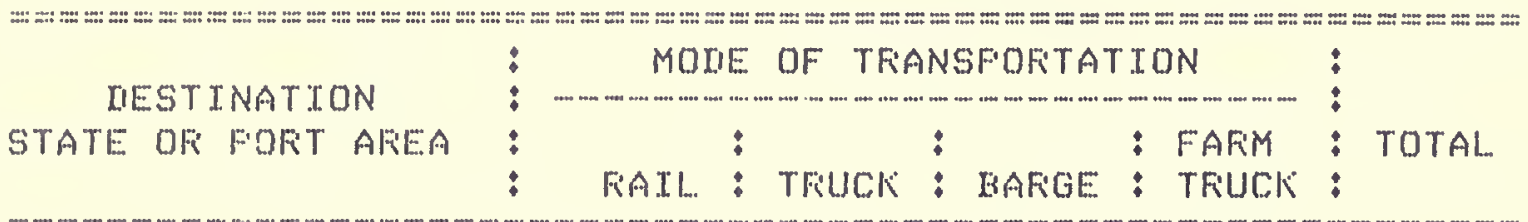

(THOUSANIIS OF ISUSHELSS)

$\begin{array}{lcrrrr}1609 \text { GEOFGIA } & 990 & 0 & 0 & 0 & 990 \\ 2410 \text { TENNESSEE } & 100 & 0 & 0 & 0 & 100 \\ 2411 \text { TENNESSEE } & 133 & 0 & 0 & 0 & 133 \\ 2412 \text { TENNESSEE } & 100 & 5030 & 0 & 1114 & 6244 \\ 2501 \text { MISSISSIFFI. } & 223 & 0 & 0 & 0 & 223 \\ 2502 \text { MISSISSIFFT } & 454 & 0 & 0 & 0 & 454 \\ 2503 \text { MISSISSIFFI. } & 1056 & 31 & 0 & 0 & 1087 \\ 2608 \text { ALABAMA } & 0 & 332 & 0 & 0 & 332 \\ 7302 \text { LOUISIANA GULF } & 0 & 0 & 2231 & 0 & 2231 \\ \text { TOTAL VOLUME } & 3056 & 5393 & 2231 & 1114 & 11794\end{array}$

TALLE 1.76. 1977 COFN FECEIFTS FFOM UAFIOUS OFIGINS BY FIFMS IN AFEA 3710, TEXAS

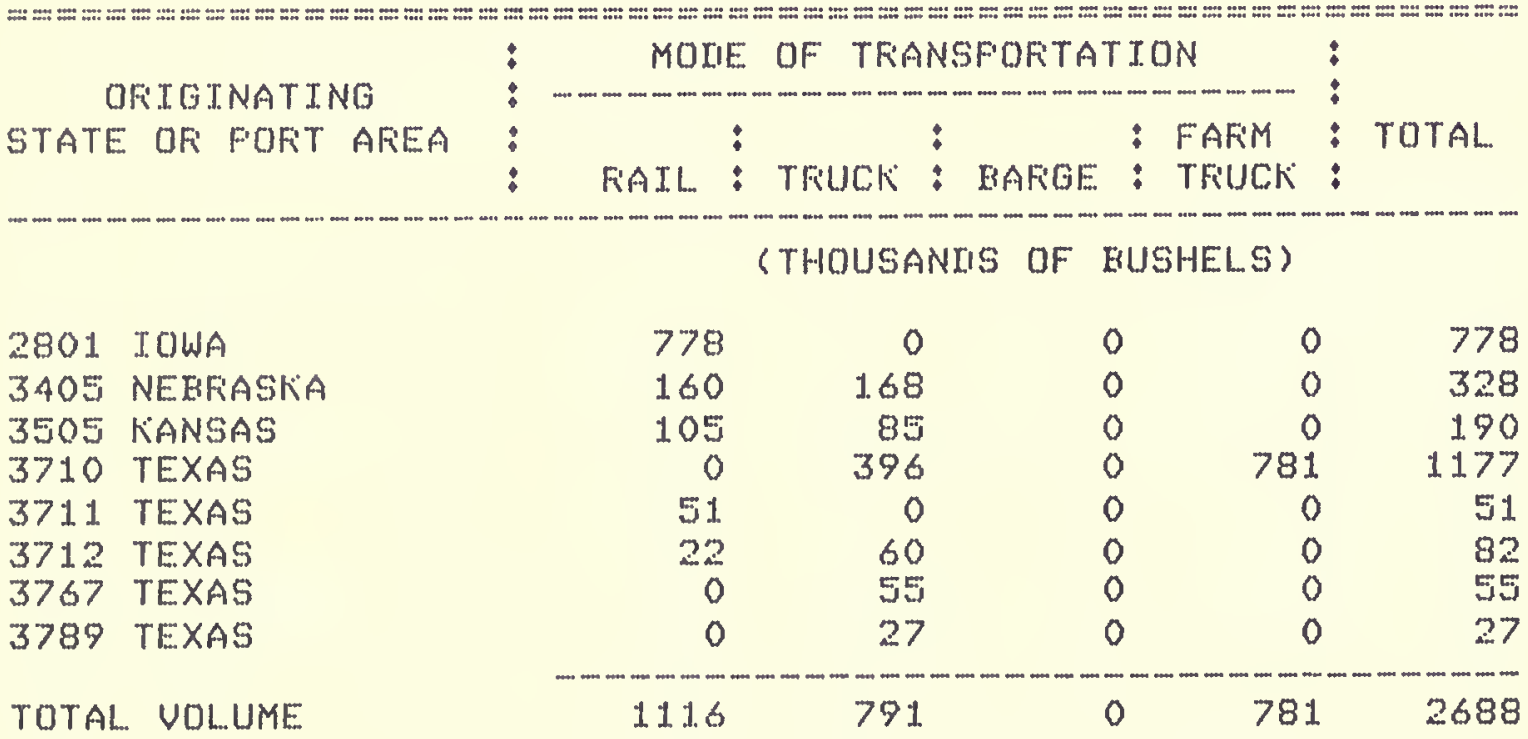


TABLE 177. IS77 COKN SHTFMENTS TO UAFIOUS RESTINATIONS BY FIFMS IN AFEA 3710 , TEXAS

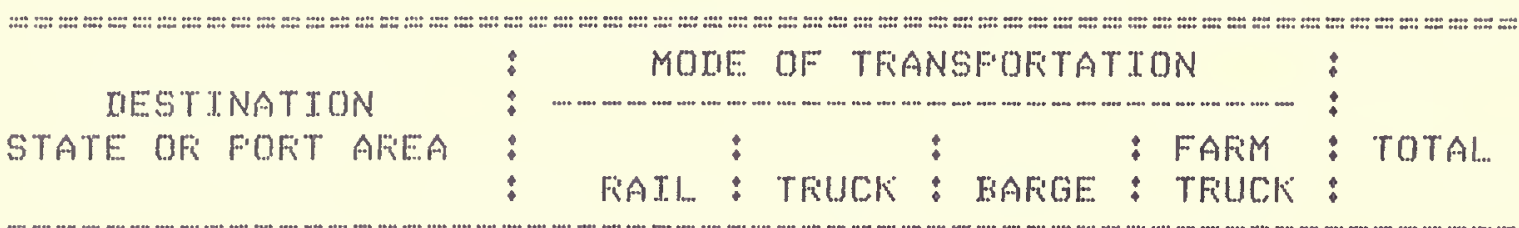

(THOUSANIS OF RUSHELS)

$\begin{array}{lrrrrr}3710 \text { TEXAS } & 0 & 396 & 0 & 0 & 396 \\ 3745 \text { TEXAS } & 0 & 110 & 0 & 0 & 110 \\ 3767 \text { TEXAS } & 0 & 33 & 0 & 0 & 33 \\ 3789 \text { TEXAS } & 0 & 375 & 0 & 0 & 375 \\ 9000 \text { EXFOFT } & 360 & 0 & 0 & 0 & 360 \\ \text { TOTAL VOLUME } & 360 & 91 . & 0 & 0 & 1274\end{array}$

TAEIEE 178. 1977 COFN FECEIFTS FFOM UAFTOUS OFIGTNS BY FTFMS IN AFEA 37LL, TEXAS



(THOUSANTIS OF BUSHELS)

\begin{tabular}{|c|c|c|c|c|c|}
\hline 3401 NEEFASKKA & 0 & 2816 & 0 & 0 & 2816 \\
\hline NEBFASKIA & 729 & 0 & 0 & 0 & 729 \\
\hline NEEFIASKKA & 21 & 0 & 0 & 0 & 21 \\
\hline KANSAS & 0 & 2420 & 0 & 0 & 2420 \\
\hline K゙ANSAS & 210 & 0 & 0 & 0 & 210 \\
\hline 3603 OKKL.AHOMA & 0 & 780 & 0 & 0 & 780 \\
\hline 3711 TEXAS & 9859 & 78932 & 0 & 112692 & 201483 \\
\hline 3712 TEXAS & 707 & 1005 & 0 & 0 & 1712 \\
\hline 4000 COLLOFAIIO & 15 & 1458 & 0 & 0 & 1473 \\
\hline TOTAL. VOLLUME & 11541 & $8741 \%$ & 0 & 112692 & 211644 \\
\hline
\end{tabular}


TABLE 179. 1977 COFN SHIFMENTS TO UAFIOUS TIESTINATIONS BY FIFIMS IN AFEA $371 \%$. TEXAS

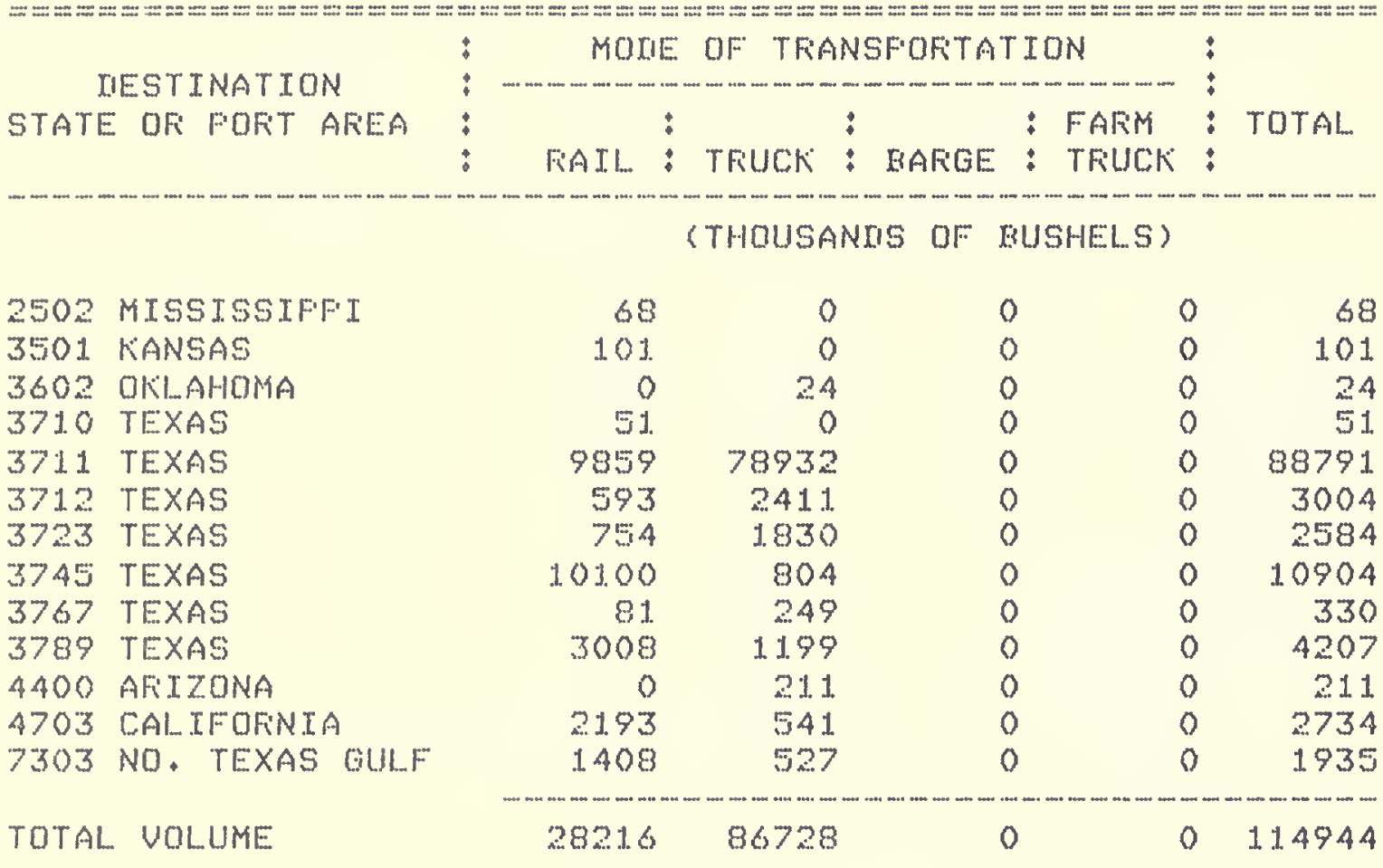

TABLE 180. 1977 COFN FECEJFTS FFOM UAFIOUS OFIGINS BY FTFMS IN AREA 3712, TEXAS

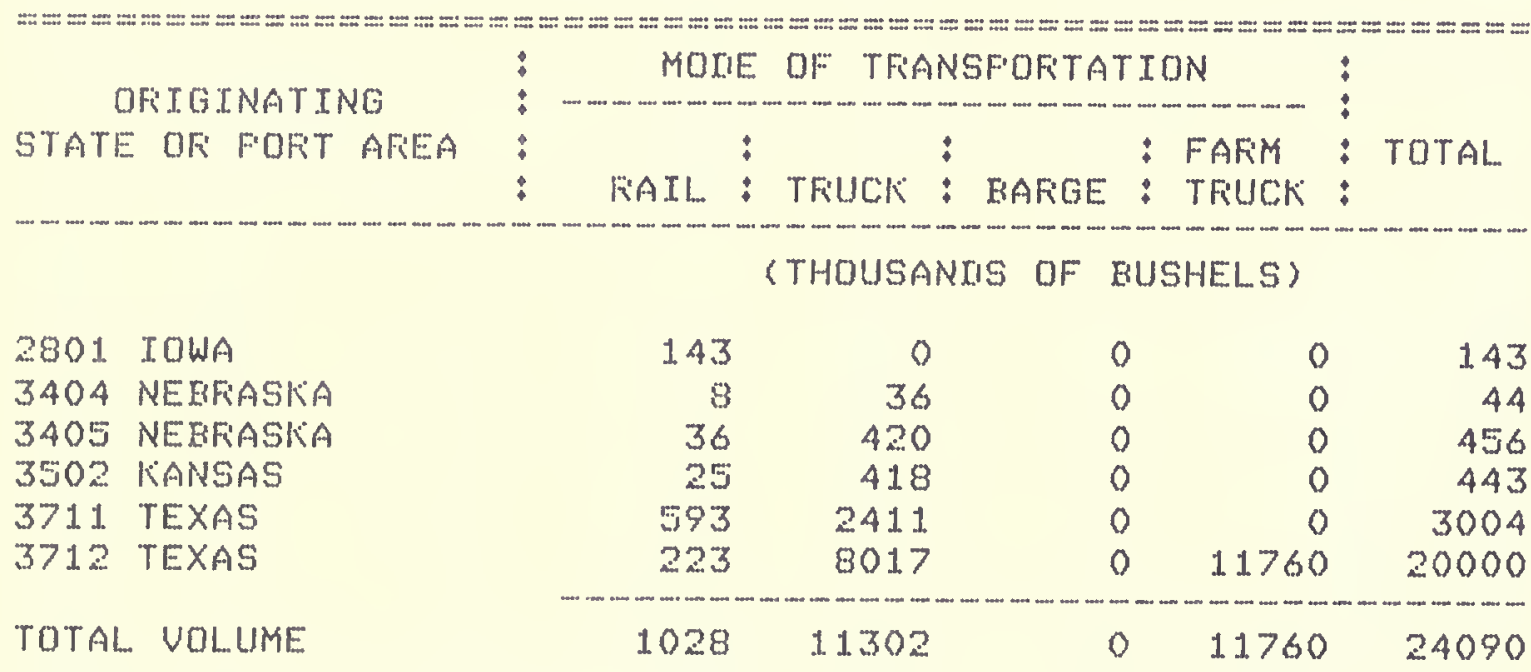


TABLE 181. 1977 COFN SHTFMENTS TO UARIOUS DESTINATIONS BY FIFMS IN AREA 3712, TEXAS

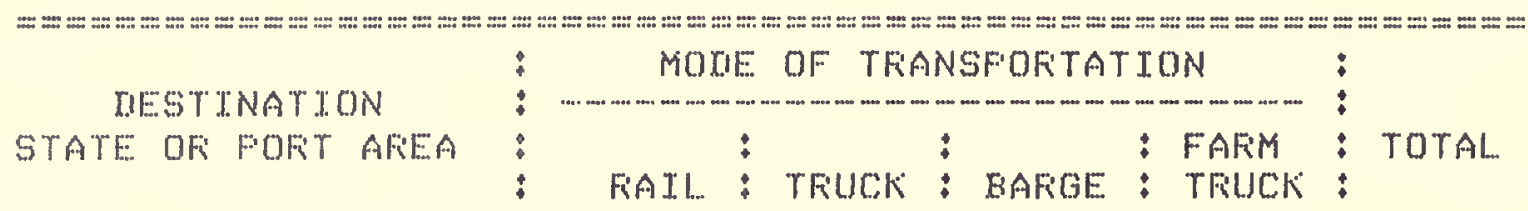

(THOUSANTIS OF EUSHELSS)

\begin{tabular}{|c|c|c|c|c|c|c|}
\hline 3710 & $T E X A S$ & 22 & 60 & 0 & 0 & 82 \\
\hline 3711 & TEXAS & 707 & 1005 & 0 & 0 & 1712 \\
\hline 3712 & TEXAS & 223 & 8017 & 0 & 0 & 8240 \\
\hline 3723 & TEXAS & 16 & 90 & 0 & 0 & 106 \\
\hline 3745 & TEXAS & 454 & 213 & 0 & 0 & 667 \\
\hline 3767 & TEXAS & 0 & 309 & 0 & 0 & 309 \\
\hline 3789 & TEXAS & 31.4 & $3: 4$ & 0 & 0 & 628 \\
\hline 4701 & CALIFOFNIA & 3161 & 0 & 0 & 0 & 3161 \\
\hline 4703 & CALIFOFNIA & 404 & 0 & 0 & 0 & 404 \\
\hline 4704 & CAL TFOFINIA & 4685 & 0 & 0 & 0 & 4685 \\
\hline 7303 & NO. TEXAS GULF & 186 & 0 & 0 & 0 & 186 \\
\hline TOTAL & VOLUME & 101.72 & 10008 & 0 & 0 & 20180 \\
\hline
\end{tabular}

TABLE 182, 1977 COFN FECETFTS FFOM VARIOUS ORIGINS BY FIFMS IN AREA 3723 , TEXAS

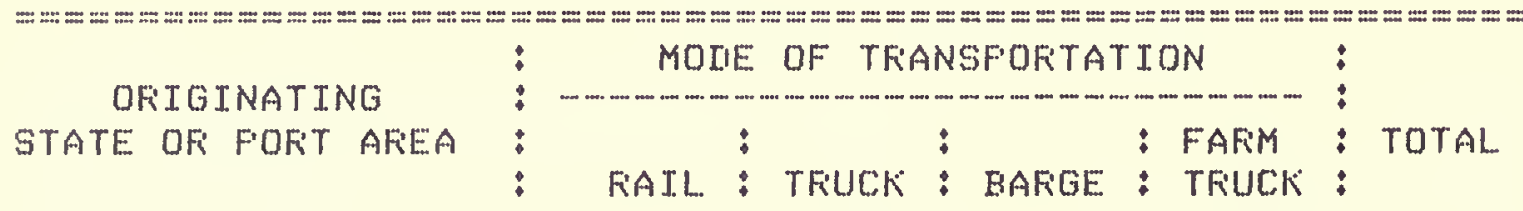

(THOUSANIIS OF FUSHELS)

2801 IOWA

2900 MISSOURI

3404 NEBFASKA

3405 NEERIASKIA

3505 KANSAS

3711 TEXAS

3712 TEXAS

3745 TEXAS

3789 TEXAS

TOTAL VOLUME

\begin{tabular}{rrrrr}
300 & 0 & 0 & 0 & 300 \\
2568 & 0 & 0 & 0 & 2568 \\
60 & 10 & 0 & 0 & 70 \\
294 & 52 & 0 & 0 & 346 \\
67 & 6 & 0 & 0 & 73 \\
754 & 1830 & 0 & 0 & 2584 \\
16 & 90 & 0 & 0 & 106 \\
0 & 10 & 0 & 0 & 10 \\
0 & 75 & 0 & 0 & 75 \\
\hline 4059 & 2073 & 0 & 0 & 6132
\end{tabular}


TABLE 183. 1977 COFN SHTFMENTS TO UAFTOUS MESTINAT TONS BY FIFMS IN AFEA 3723 , TEXAS

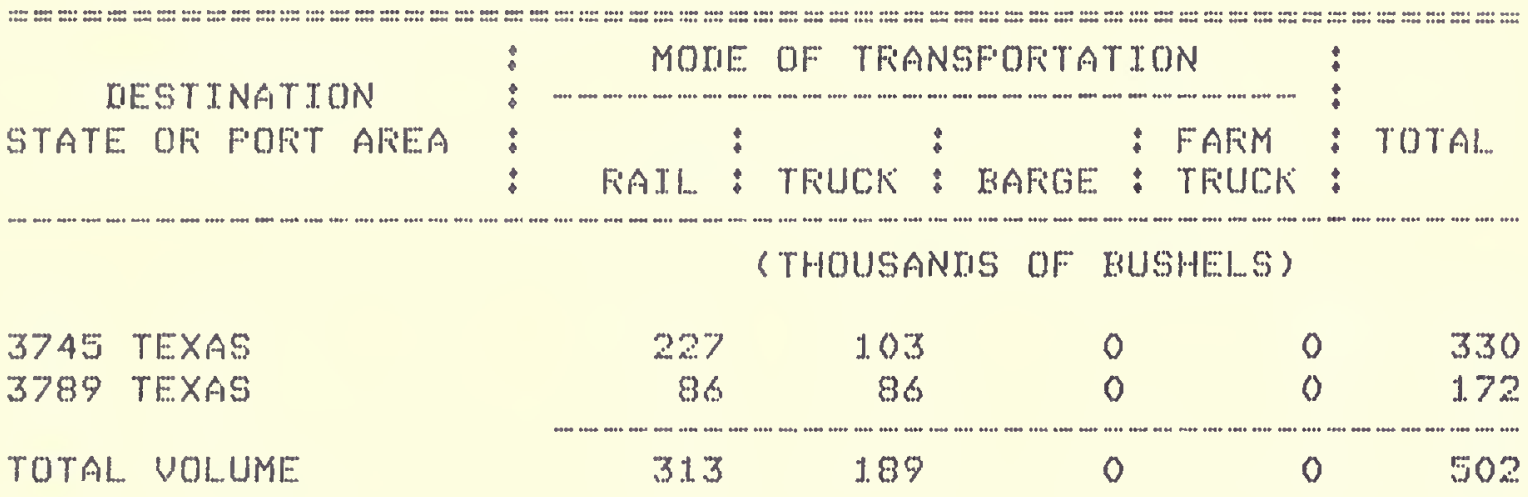

TAELE 184. 1977 COFN FECEIFTS FFOM UAFIOUS OFIGTNS EY FTIMMS IN AREA 3745 , TEXAS

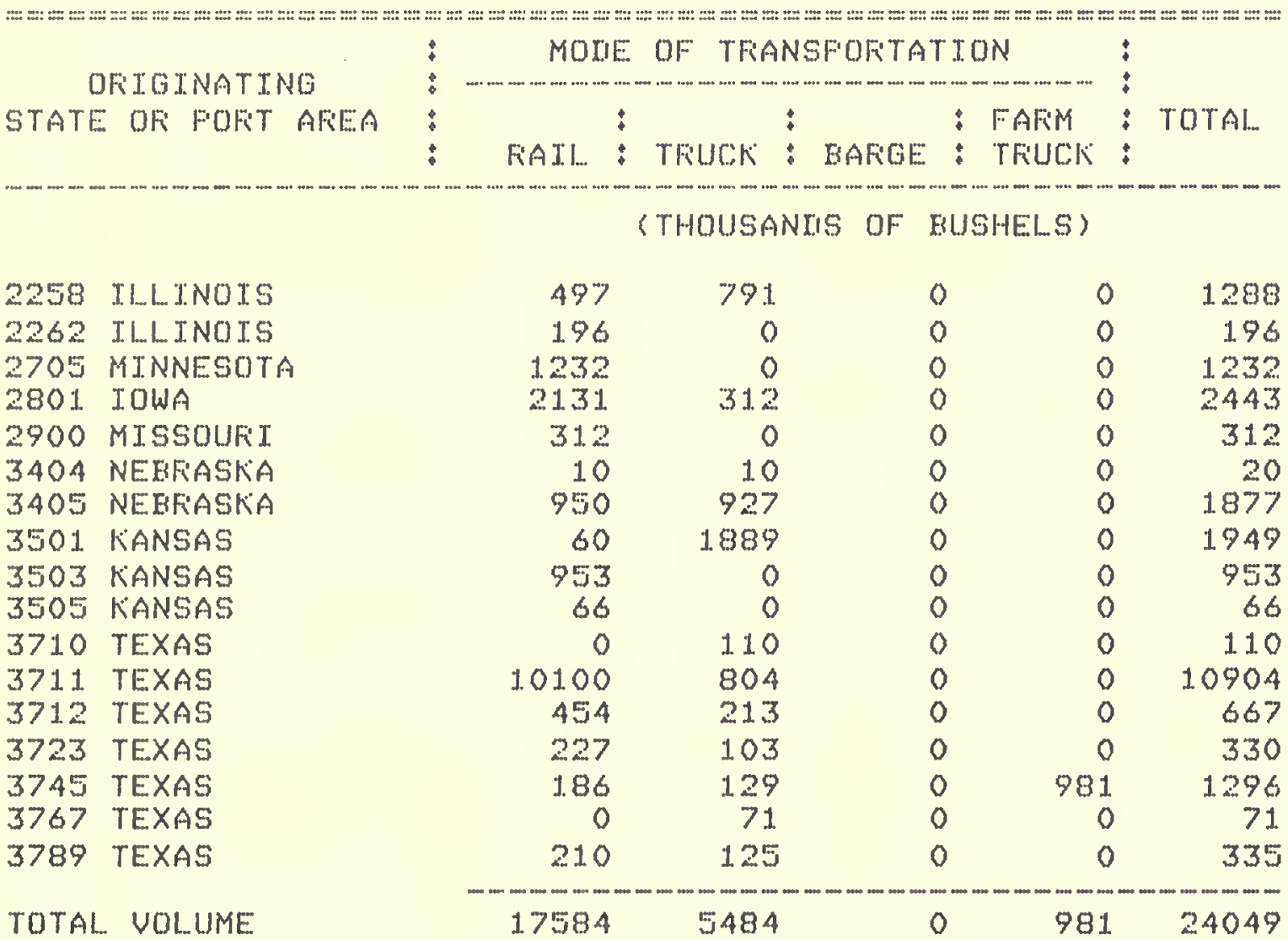


TAELE 185. 1977 COFN SHIFMENTS TO UAFIOUS IIESTINATIDNS BY FIFMS TN AFEA 3745 , TEXAS

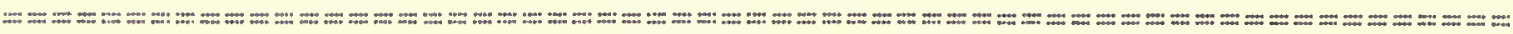

IIESTINATTON

STATE OF FOFT AFEA

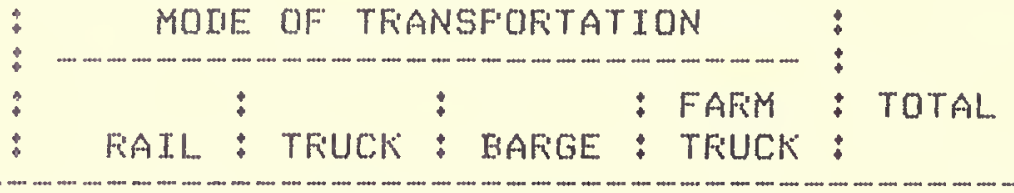

(THOUSANLS OF BUSHELS)

$\begin{array}{lccccr}3723 \text { TEXAS } & 0 & 10 & 0 & 0 & 10 \\ 3745 \text { TEXAS } & 186 & 129 & 0 & 0 & 315 \\ 3789 \text { TEXAS } & 0 & 480 & 0 & 0 & 480 \\ \text { TOTAL UOLUME } & 186 & 619 & 0 & 0 & 805\end{array}$

TAELE 186. 1977 COFN FECEIFTS FFOM VAFIOUS OFIGINS BY FIFMS IN AFEA 3767 Y TEXAS

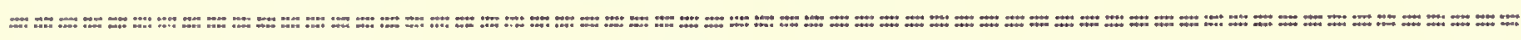

OFTGINATTNG

STATE OF FOFT AFEA
MOLE OF TFANSFORTATTON

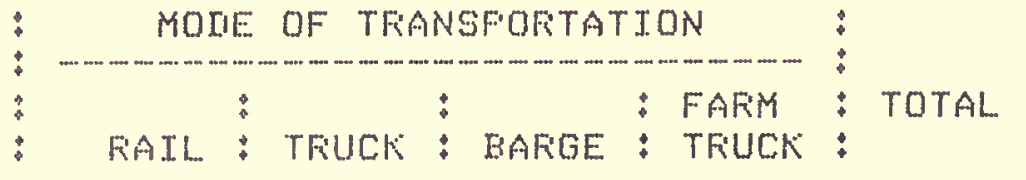

$\begin{array}{llrrrrr}3710 \text { TEXAS } & 0 & 33 & 0 & 0 & 33 \\ 3711 \text { TEXAS } & 81 & 249 & 0 & 0 & 330 \\ 3712 \text { TEXAS } & 0 & 309 & 0 & 0 & 309 \\ 3767 \text { TEXAS } & 0 & 61 & 0 & 1586 & 1647 \\ 3789 \text { TEXAS } & 0 & 380 & 0 & 0 & 380 \\ \text { TOTAL VOLUME } & 81 & 1032 & 0 & 1586 & 2699\end{array}$

TABLE 187. 1977 CORN SHIFMENTS TO UARIOUS DESTINATIONS BY FIFIMS IN AFEA 3767 , TEXAS

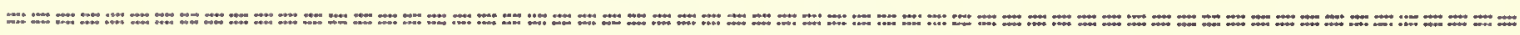

TIESTINATION

STATE OF FOFT AFEA
MOIE OF TFANSFOFTATION

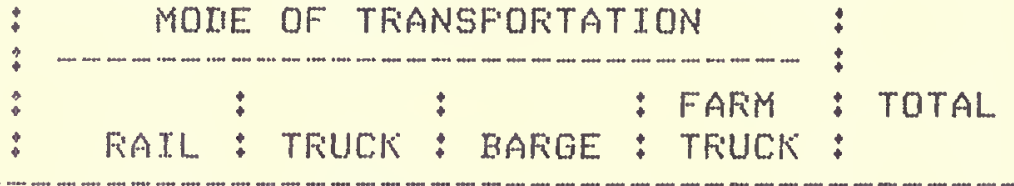

(THOUSANIS OF EUSHELS)

$\begin{array}{lrcccr}3710 \text { TEXAS } & 0 & 5 & 0 & 0 & 55 \\ 3745 \text { TEXAS } & 0 & 71 & 0 & 0 & 71 \\ 3767 \text { TEXAS } & 0 & 61 & 0 & 0 & 61 \\ 3789 \text { TEXAS } & 99 & 142 & 0 & 0 & 241 \\ 4703 \text { CALIFOFNIA } & 213 & 0 & 0 & 0 & 213 \\ \text { TOTAL VOLUME } & 312 & 329 & 0 & 0 & 641\end{array}$

31: 
TABLE 138. 1977 COFN FECEJFTS FFOM UARIOUS ORIGINS BY FIFMS IN AREA 3789 , TEXAS

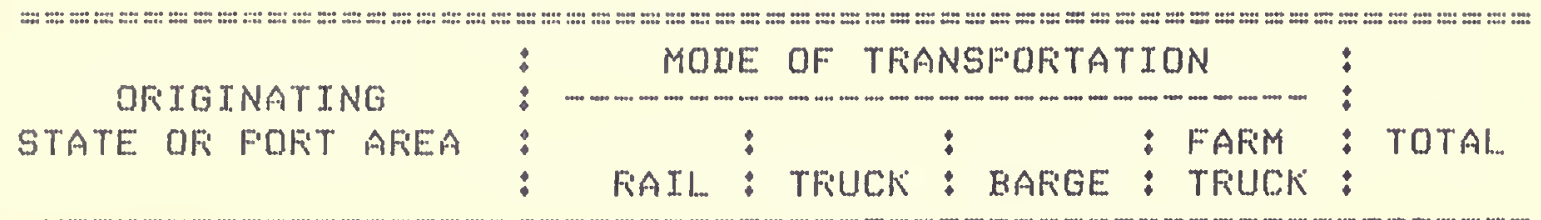

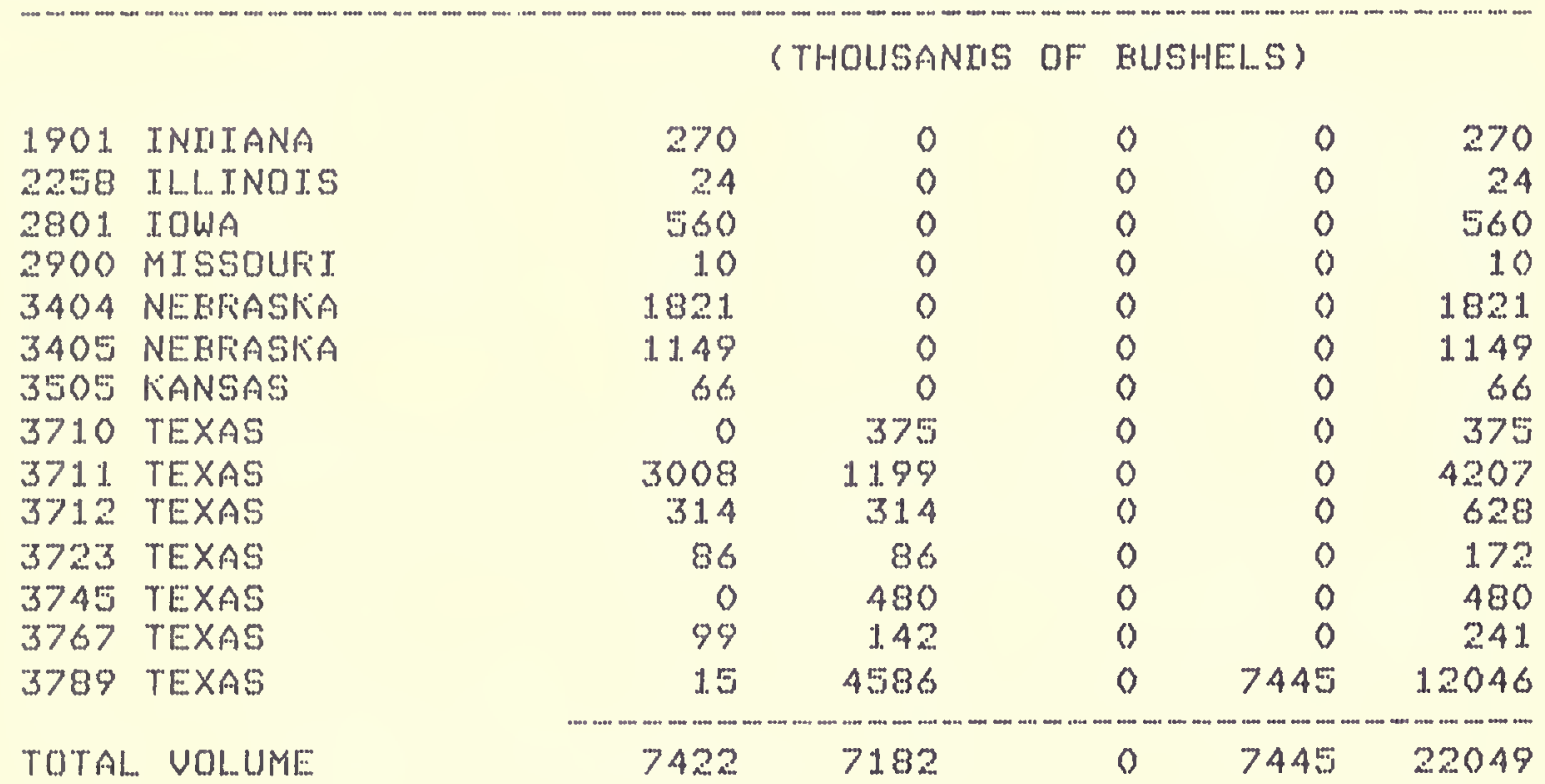

TAELE 189. 1977 COFN SHIFMENTS TO VAFIOUS DESTINATIONS EY FIFMS IN AFEA 3789 , TEXAS

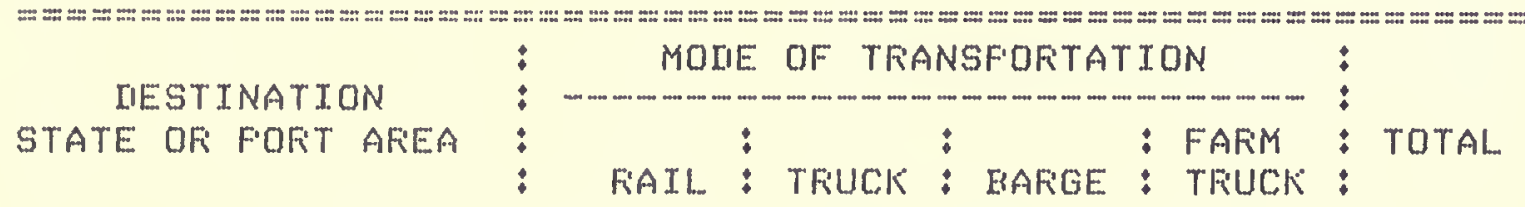

(THOUSANIIS OF BUSHELS)

$\begin{array}{lrrrrr}3710 \text { TEXAS } & 0 & 27 & 0 & 0 & 27 \\ 3723 \text { TEXAS } & 0 & 75 & 0 & 0 & 75 \\ 3745 \text { TEXAS } & 210 & 125 & 0 & 0 & 335 \\ 3767 \text { TEXAS } & 0 & 380 & 0 & 0 & 380 \\ 3789 \text { TEXAS } & 15 & 4586 & 0 & 0 & 4601 \\ 7303 \text { NO. TEXAS GUIF } & 0 & 1185 & 0 & 0 & 1185 \\ 7304 \text { SO. TEXAS GULF } & 0 & 125 & 0 & 0 & 125 \\ \text { TOTAL VOLUME } & 225 & 6503 & 0 & 0 & 6728\end{array}$


TAFLE 1.90. 1977 COFN FECETFTS FFOM UAFIOUS OFTGINS BY FTKMS IN AFEA 4300 , UTAH

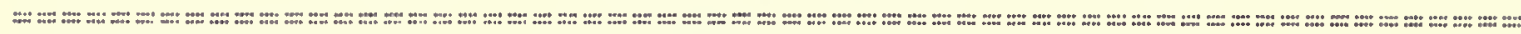

OFTGTNATING

STATE DF FOFT AFEA
MOIE OF TFANSFOFTATTON

: FAFIM

FAAL: : TFUCK: BAFGE: TFUCK :

(THOUSANIS OF EUSHEISS)

3200 NOFTH MAKIOTA

3404 NEBFASKA

4000 COLOFIAIO

4300 UTAH

TOTAL VOI...IME

$\begin{array}{rrrrr}500 & 0 & 0 & 0 & 500 \\ 2351 & 0 & 0 & 0 & 2351 \\ 972 & 399 & 0 & 0 & 1371 \\ 0 & 0 & 0 & 72 & 72 \\ 3823 & 399 & 0 & 72 & 4294\end{array}$

TAELE 191, 1977 COFIN FECETFTS FFOM UAFIOUS OFTGING BY FTEMS IN AFEA 300 . UEFMONT

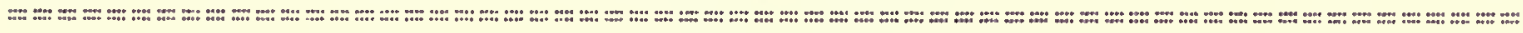

OFIGINATING

STATE OF FORT AFEA
MOIIE OF TFANSFOFTATTON

- FAFM

TRUCK

(THOUSANDS OF RUSHELS)

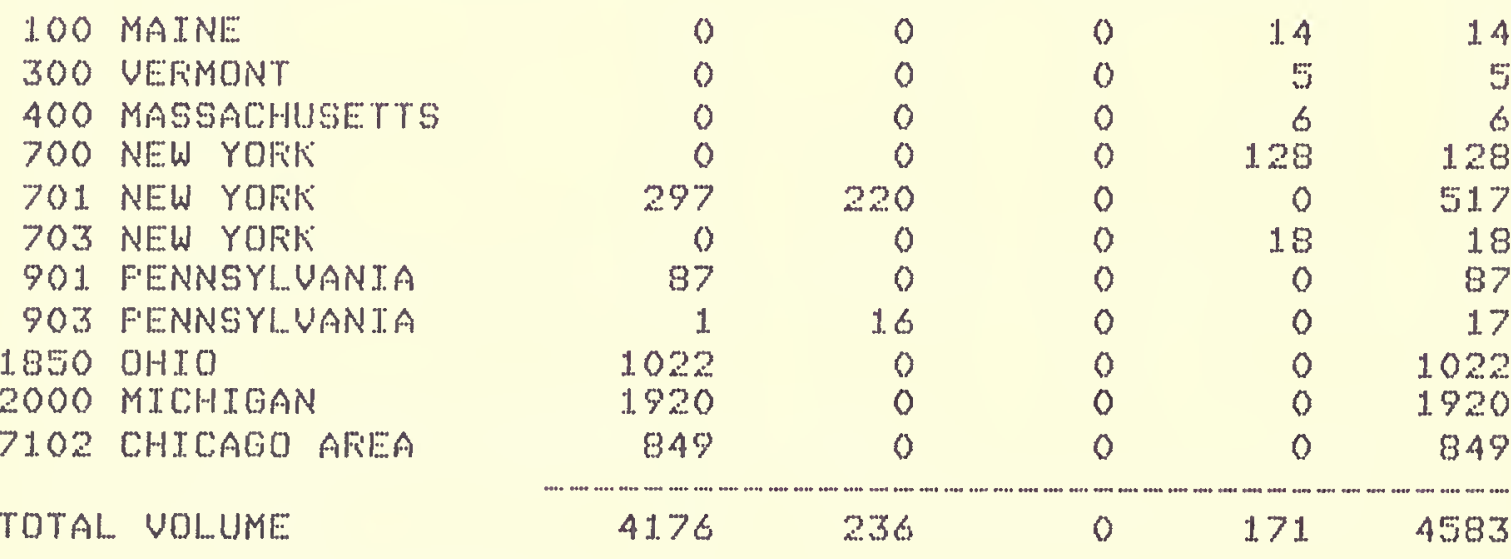

TABLE 192. 1977 COFN SHTFMENTS TO UARTOUS IESTINATIONS BY FIFMS IN AFEA 300 , UEFMONT

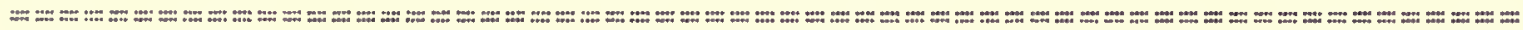

IIESTINATION

STATE OF FOFIT AFEA
MOIE OF TFIANSFOFTATION

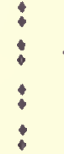

FATL : TFUCK : BAFGE : FAFUM :

TOTAL.

(THOUSANIIS DF EUSHELS)

300 VEFMONT

TOTAL VOLUME

10

0

0

0

4 
TAELE 1.93. 1977 COFN FECEIFTS FFOM UARIOUS OFJGINS EY

FIFMS TN AFEA 1200 , VTFIOINIA

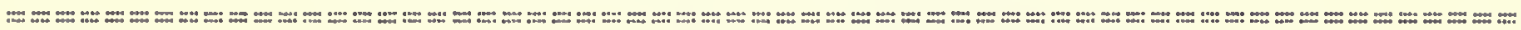

OFITGINATING

STATE OF FOFT AFEA
MOIE OF TFANSFOFTATION

MOIE OF TFANSFOFTATION
$\vdots$ FIAIL

(THOUSANIS OF BUSHELS)

903 FENNSYLUANIA

1100 MAFIYLANL

1200 UIFIGINIA

1400 NOFTH CAFIOLINA

1 J0O SOUTH CAFOLINA

1902 INIIIANA

1903 INLIIANA

2319 KEENTUCKKY

2410 TENNESSEF:

7202 SOUTH ATLANTIC

TOTAL. VOLLUME

$\begin{array}{rrrrr}0 & 36 & 0 & 0 & 36 \\ 0 & 93 & 0 & 0 & 83 \\ 95 & 62 & 0 & 21007 & 21164 \\ 0 & 0 & 0 & 3476 & 3476 \\ 805 & 0 & 0 & 0 & 805 \\ 120 & 0 & 0 & 0 & 120 \\ 798 & 0 & 0 & 0 & 798 \\ 45 & 0 & 0 & 0 & 45 \\ 0 & 3 & 0 & 0 & 3 \\ 0 & 221 & 359 & 0 & 580 \\ 1863 & 403 & 359 & 24483 & 27110\end{array}$

TAELE 194. 1977 COFN SHTFMENTS TO UAFIOUS IIESTINATIONS EY

FIFIMS IN AFEA 1200 , VIFIGINTA

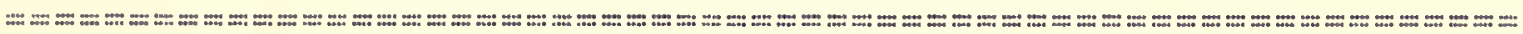

DIESTINATION

STATE OFI FOFT AFEA
MOLE OF TFANSFOFTATION

:

: : : FAFM :

FAIL: TFIUCK : EARGE: TFUCK :

(THOUSANIIS OF EUSHELS..S)

1200 VIFEINIA

7202 SOUTH ATLANTIC

TOTAL. VOL..UYE

\begin{tabular}{ccccc}
95 & 62 & 0 & 2268 & 2425 \\
0 & 0 & 1611 & 0 & 1611 \\
\hline 5 & 62 & 1611 & 2268 & 4036
\end{tabular}

TAELE 195. 1977 COFN FECEIFTS FFOM VAFIOUS OFITGINS BY

FIFMS IN AFEA 4500 \% WASHINGTON

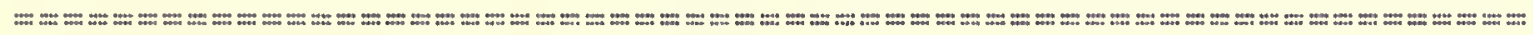

ORTGINATING

STATE OR FOFT AFEA
MOLIE OF TFANSFOFTATION

!

FAIL : TFUCK : HAFGE : FAFMCK :
0

0

0

0

0

0




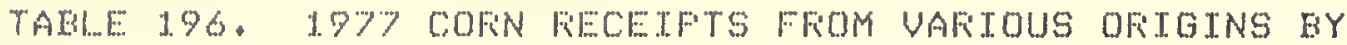
FIFMS TN AFEA 1300 , WEST UTFGTNTA

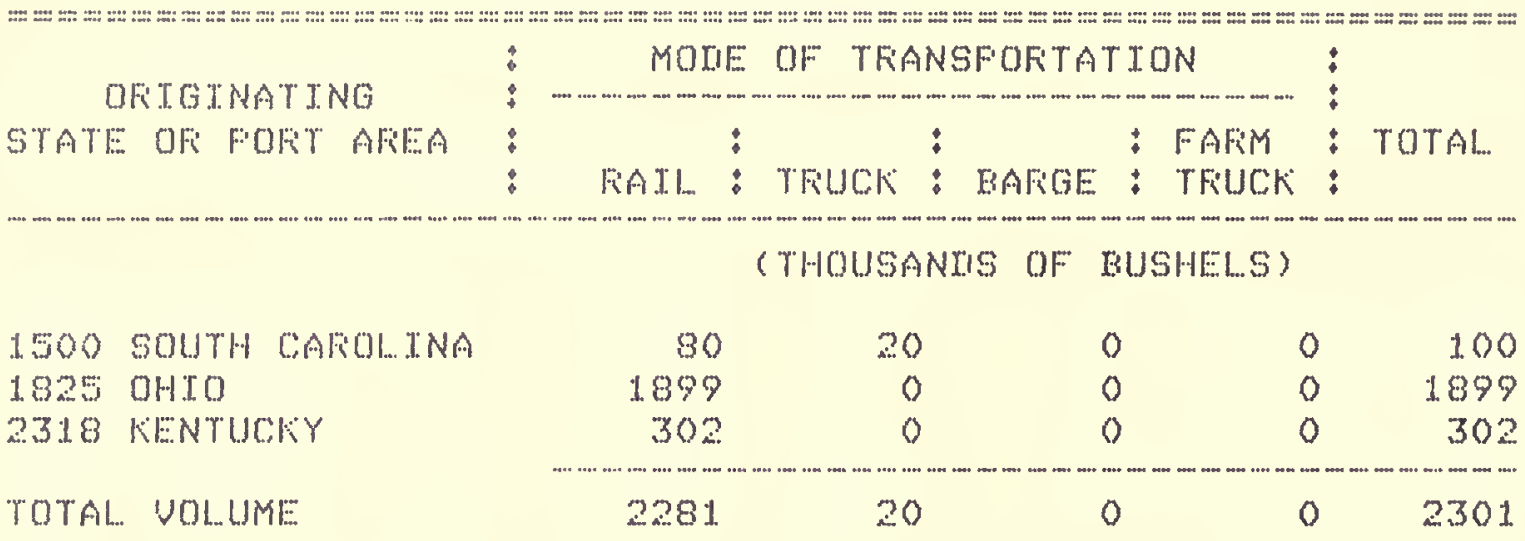

TAELE 197. 1.97\% COFN FECETFYS FFOM UAFTOUS OFTGINS BY FTFMS TN AREA 2IOI, WISCONGIN

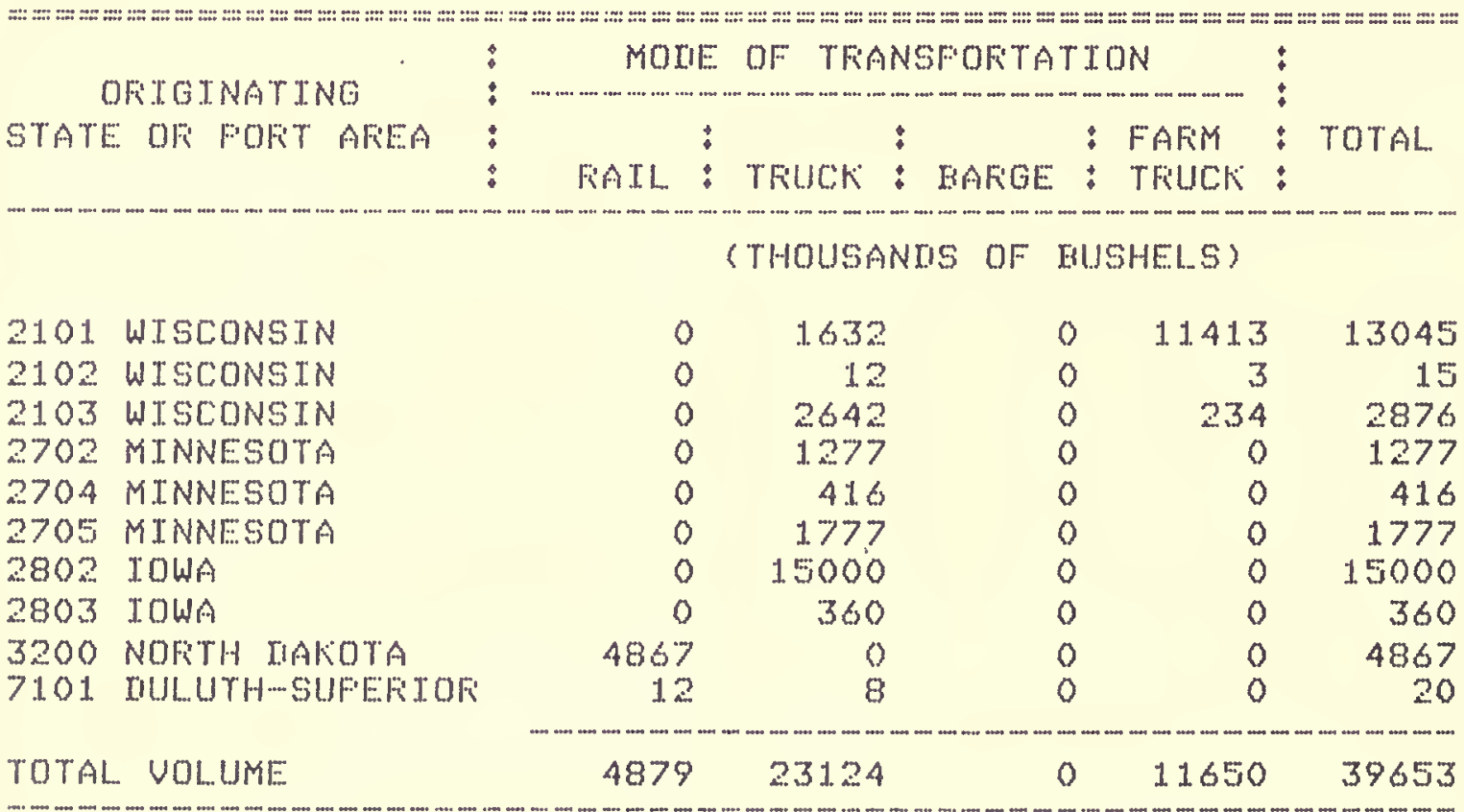


TAELE 199. 1977 COKN SHTFENTS TO UARIOUS RESTINATIONS BY FIFMS TN AREA 210\%, WISCONSIN

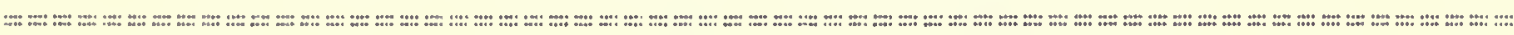

IESTINATION

STATE OF FOFT AFEA

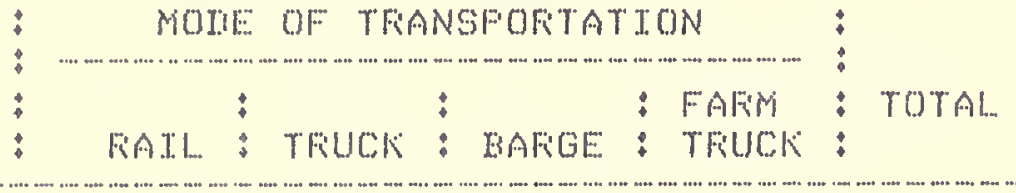

(THOUSANIS OF BUSHELS)

\begin{tabular}{|c|c|c|c|c|c|}
\hline 2101 WISCONSTN & 0 & 1632 & 0 & 96 & 1728 \\
\hline WTCONSTN & 0 & 36 & 0 & 0 & 36 \\
\hline MINNESOTA & 0 & 4542 & 0 & 0 & 4542 \\
\hline IIULUTH SUFERTOF & 48 & 24 & 0 & ) & 72 \\
\hline CHTCAOO AFEA & 0 & 204 & 0 & 0 & 204 \\
\hline
\end{tabular}

TABLE 199, 1977 COFN FECETFTE FROM VARTOUS ORTGTNS BY FIFIMS IN AREA 2102 Y WTSCONSIN

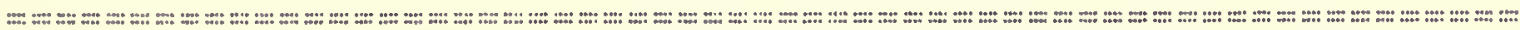

DFTGTANTING

STATE OR FOFT AFEA
MOME OF TFANSWOFTATION

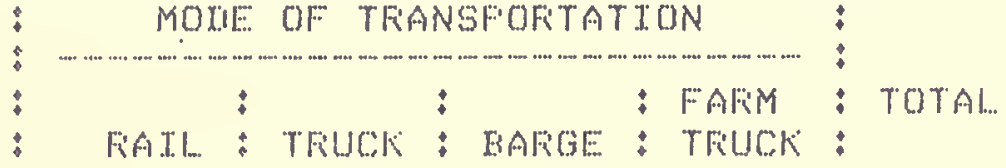
$\cdots$

\section{(THOUSANTS OF BUSHELS)}

$\begin{array}{llccrr}2102 \text { WISCONSTN } & 0 & 451 & 0 & 8951 & 9402 \\ 2103 \text { WISCONSIN } & 0 & 312 & 0 & 375 & 687 \\ 2705 \text { MINNESOTA } & 0 & 4400 & 0 & 0 & 4400 \\ 7102 \text { CHICACOAFEA } & 0 & 240 & 0 & 0 & 240 \\ \text { TOTAL VOLUME } & 0 & 5403 & 0 & 9326 & 1.4729\end{array}$

TABLE 200, 1977 COFN SHTFMENTS TO VAFIOUS IESTINATIONS FY FTFMS TIN AFEA 2102 Y WISCONSIN

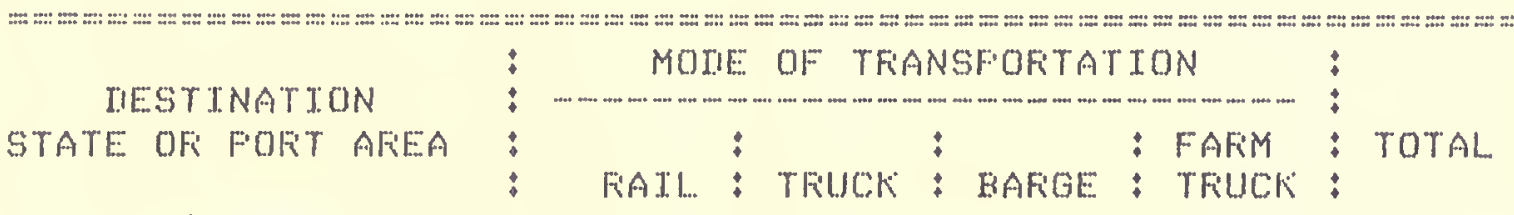

$\begin{array}{lcccrr} & & & \\ 2101 \text { WISCONSIN } & 0 & 12 & 0 & 0 & 12 \\ 2102 \text { WISCONSIN } & 0 & 451 & 0 & 355 & 806 \\ 2103 \text { WISCONSIN } & 0 & 104 & 0 & 30 & 134 \\ 2705 \text { MINNESOTA } & 0 & 474 & 0 & 0 & 474 \\ 7102 \text { CHICAGO AREA } & 0 & 661 & 0 & 0 & 661 \\ \text { TOTAL UOLUME } & 0 & 1702 & 0 & 385 & 2097\end{array}$


TAEHE 201.977 COFN FECEIFTS FFOM VAFIOUS OFIGINS BY FIFMS IN AREA 2103 , WISCONSIN

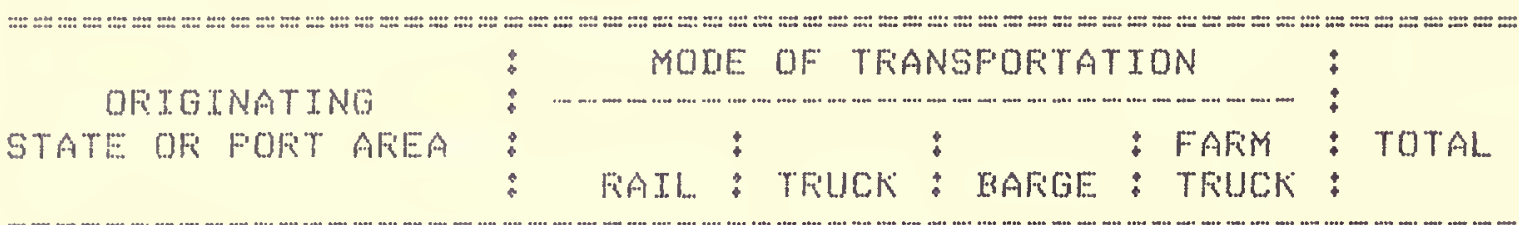

(THOUSANDS OF RUSHELS)

\begin{tabular}{|c|c|c|c|c|c|c|}
\hline 2101 & WISCONSTN & 0 & 36 & 0 & 328 & 364 \\
\hline 2102 & WTSCONSIN & 0 & 104 & 0 & 55 & 159 \\
\hline 2103 & WTSCONSIN & 0 & 861 & 0 & 35403 & 36264 \\
\hline 2256 & ILLINOTS & 0 & 0 & 0 & 1135 & 1135 \\
\hline 2257 & ILI. TNOTS & 0 & 18 & 0 & 0 & 18 \\
\hline 2260 & ILLINOTS & 0 & 18 & 0 & 0 & 18 \\
\hline 270 & MINNESOTA & 1. 57 & 2206 & 0 & 133 & 2496 \\
\hline 2802 & TOWA & 0 & 36 & 0 & 0 & 36 \\
\hline 2803 & TOWA & 0 & 3793 & 0 & 92 & 888 \\
\hline DTAL. & VO1..UME & 157 & 12072 & 0 & 371.46 & 49375 \\
\hline
\end{tabular}

TABLE 202. $197 \%$ COFN SHIFENTS TO VAFTOUS RESTINATIONS EY FTEMS TN AFEA 2103 , WISCONSTN

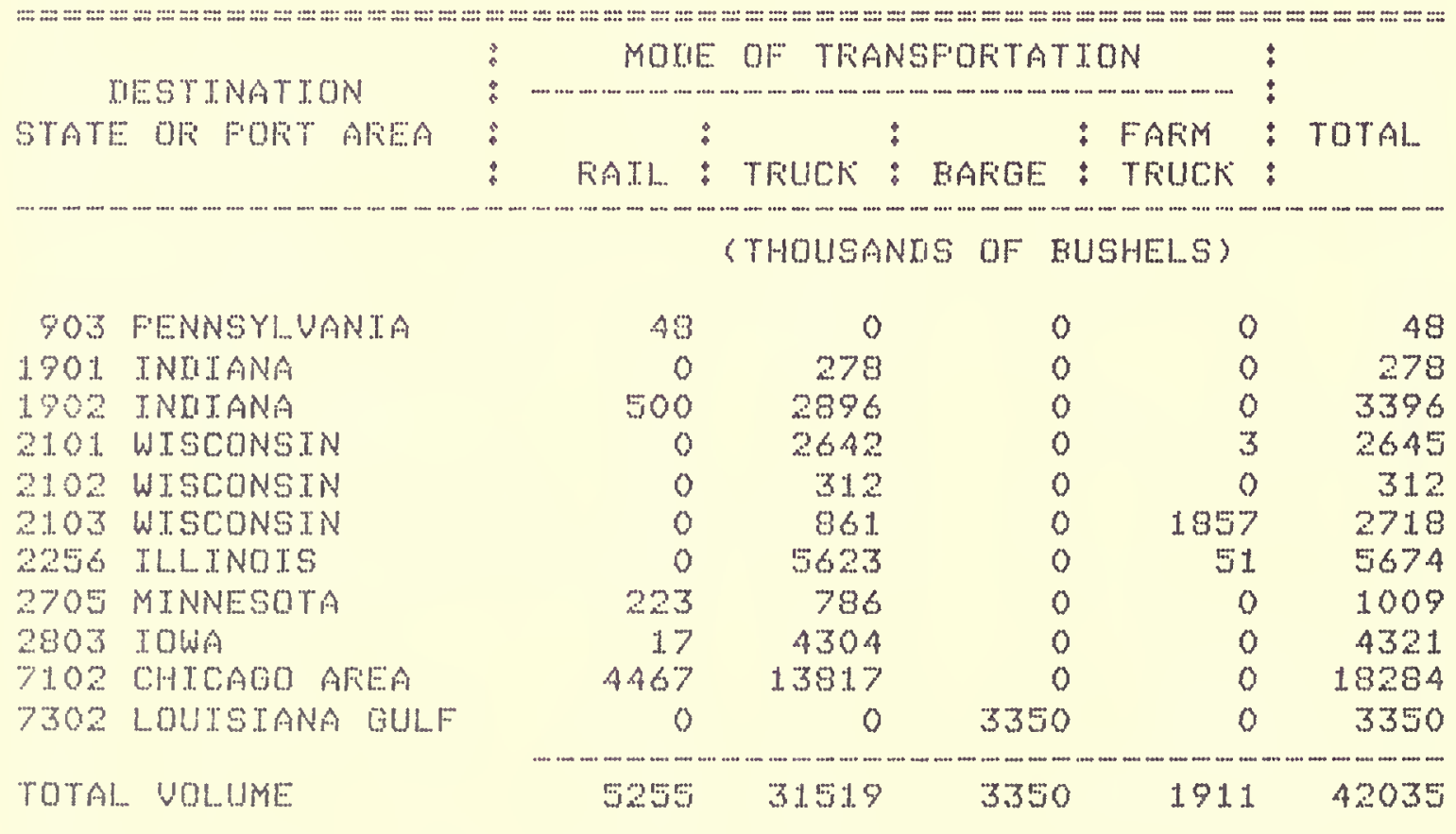


TABLE 203. 1.977 COFN FECEJFTS FFOM UAFIOUS OFTGINS BY

FIVMS TN AREA 3900 , WYOMTNG

1:

DFITGNATING

STATE OF FOFT AFEA

MONE OF TFANSFOFTATTON
$\vdots$ KATL : TRUCK : BAFGE : TFUCK : TOTAL

(THOUSANIS OF HUSHEI...S)

$\begin{array}{lrrrrr}3200 \text { NOFIH IIAKOTA } & 500 & 0 & 0 & 0 & 500 \\ 3401 \text { NEBFIASKIA } & 0 & 65 & 0 & 0 & 65 \\ 340 A \text { NERFASKA } & 0 & 56 & 0 & 0 & 56 \\ 3405 \text { NEBFASKA } & 0 & 7 & 0 & 0 & 7 \\ 3900 \text { WYOMING } & 0 & 0 & 0 & 236 & 236 \\ \text { TOTAL WOLUME } & 500 & 128 & 0 & 236 & 364\end{array}$

TABLE 20A, 1977 COFN SHTFMENTS TO WAFTOUS LIESTINATIONS BY FIFUS IN AFE:A 3900 y WYOMINO

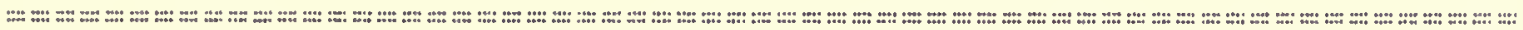

DIFSTINATION

STATE OF FOFT ARI:::A
MODE OF TFANSFORTATTON

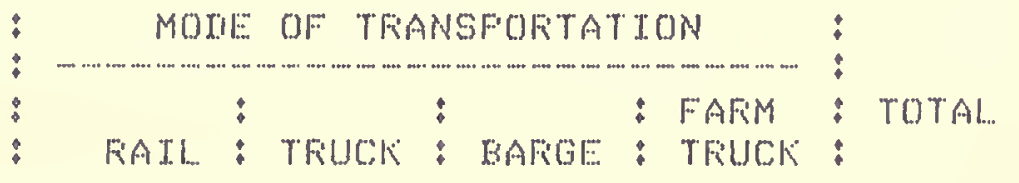

(THOLSANDIS OF FUSHEIS)

3900 WYOMINO

$\begin{array}{ccccc}0 & 0 & 0 & 45 & 45 \\ 0 & 0 & 0 & 45 & 45\end{array}$

TOTAL. VOL.UME

TABLE 205. 1979 CORN RECETFTS FFOM UAFIOUS OFICINS HY

FIFMS IN AREA 7101, IULUUTHWSUFEFIOF

:

OFIGINATING

STATE OF FOFT AFEA
MOLIE OF TFANSFOFTATTON

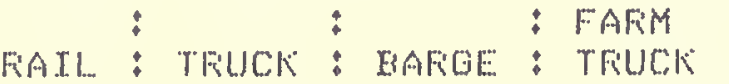

\section{(THOUSANIS OF BUSHELS)}

2101 WISCONSIN

2703 MINNESOTA

2704 MINNESOTA

2705 MINNESOTA

2801 IOWA

2802 IOWA

3200 NOFITH LIAKOTA

3301 SOUTH LIAKOTA

TOTAL VOLUME

$\begin{array}{rrrrr}48 & 24 & 0 & 0 & 72 \\ 614 & 259 & 0 & 0 & 873 \\ 3664 & 333 & 0 & 0 & 3997 \\ 4 & 29 & 0 & 0 & 33 \\ 51 & 0 & 0 & 0 & 51 \\ 185 & 0 & 0 & 0 & 185 \\ 208 & 40 & 0 & 0 & 248 \\ 654 & 73 & 0 & 0 & 727 \\ 5428 & 758 & 0 & 0 & 6186\end{array}$


TABLE: 206. $19 \% \%$ COKN SHIFMENT TO UAFTOUS DESTINATIONS EY

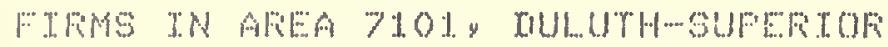

\begin{tabular}{|c|c|c|c|c|c|c|}
\hline \multirow[b]{2}{*}{ IIESTTNATTON } & $\vdots$ & MOLE: & of: TK & INGFOETA & $\operatorname{ToN}$ & \multirow{3}{*}{ Tormin. } \\
\hline & : & : & & : & $: F$ & \\
\hline & $:$ & RAII. & YRUCK & : BAFICE & $: T$ & \\
\hline
\end{tabular}

(THOUSANMS OF RUSHELS)

3101 WTOCONST

2702 MNAESOTH

9000 EXFOFT

TOTAL... VOL..UHE

$\begin{array}{rrrrr}12 & 8 & 0 & 0 & 20 \\ 4 & 6 & 0 & 0 & 10 \\ 0 & 0 & 5599 & 0 & 599 \\ 16 & 4 & 5989 & 0 & 5629\end{array}$

TABLE 20\%, 1979 COFN SECETFE FFOM VAFTOUS OFTETNS BY FIFMS IN AFEA 7DOZ Y CHICAGO AFEA

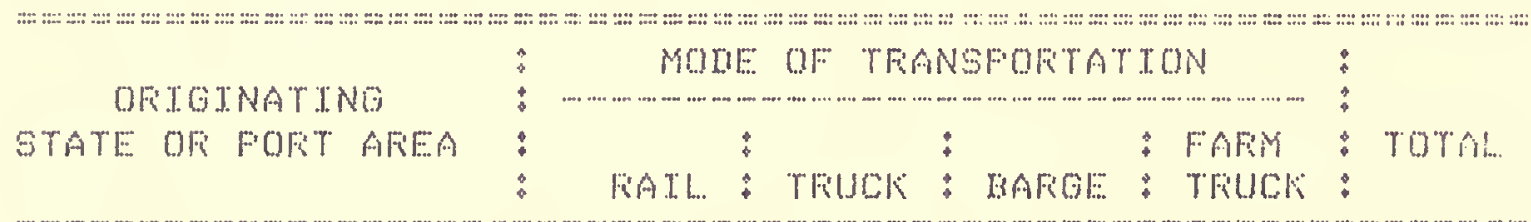

(THOUSANDS OH [USHELS)

1901 INIIIANA

2000 MTCHTGAN

2100 WTSCONSIN

2101 WTSCONSTN

2102 WISCONSIN

2103 WISCONSIN

2206 IILINOTS

2207 ILI. TNOIS

2258 TLL TNOTS

2704 MINNESOTA

2705 MINNESOTA

2801 IOWA

2802 IOWA

2803 IOWA

7102 CHICAGO AFEA

TOTAL VOLUME

\begin{tabular}{|c|c|c|c|c|}
\hline 0 & 21034 & 0 & 0 & $\therefore 1034$ \\
\hline 0 & 2847 & 0 & 0 & 29.47 \\
\hline 0 & 0 & 0 & 8064 & 8064 \\
\hline 0 & 204 & 0 & 33 & 237 \\
\hline 0 & $66 \%$ & 0 & 89 & 750 \\
\hline 4.467 & 1.3817 & 0 & 275 & 18559 \\
\hline 1934 & 22463 & 3665 & 95 & 28157 \\
\hline 711 & 953 & 0 & 0 & 1664 \\
\hline 0 & 2 & 0 & 0 & 250 \\
\hline 107 & 0 & 0 & 0 & 107 \\
\hline 96 & 0 & 0 & 0 & 96 \\
\hline 3457 & 13.41 & 0 & 0 & 4798 \\
\hline 8081 & 7992 & 0 & 0 & 16073 \\
\hline 7300 & 4421 & 0 & 0 & 11721 \\
\hline 3259 & 602 & 531 & 0 & 4392 \\
\hline 29412 & 76697 & 4196 & 8556 & 118851 \\
\hline
\end{tabular}


TABLE 208, 1977 COFN SHIFMENTS TO VAFTOUS RESTINATIONS BY FIFMS TN AFEA 7102, CHICAGO AFEA

\begin{tabular}{|c|c|c|c|c|c|c|}
\hline IIESTINATION & \multicolumn{4}{|c|}{ MOCE OF TFANSFOFTATION } & $\vdots$ & \multirow{3}{*}{ TOTAL } \\
\hline STATE OF FOFT AFEA & : & $:$ & $:$ & : FAFIM & $\vdots$ & \\
\hline & FIAIL & : TRUCK & : BARGE & : TFUCK & : & \\
\hline & & C THOUSA & ANIIS OF & EUSHELS? & & \\
\hline 100 MATNE & 443 & ( & ) & 0 & 0 & 443 \\
\hline 300 UEFMMONT & 849 & C & 0 & 0 & 0 & 849 \\
\hline 600 CONNECTTCUT & 368 & C & 0 & 0 & 0 & 368 \\
\hline 903 FENNSYLUANIA & 48 & ( & 0 & 0 & 0 & 48 \\
\hline 2102 WISCONSIN & 0 & $\therefore 40$ & & 0 & 0 & 240 \\
\hline 2256 ILLINOTS & 0 & 300 & & 0 & 0 & 300 \\
\hline 7102 CHICAGO AFEA & 32159 & 602 & 53 & & 0 & 4392 \\
\hline 7201 NOFTH ATLANTIC & 700 & ( & 0 & 0 & 0 & 700 \\
\hline 7202 SOUTH ATLANTIC & 1502 & C & 0 & 0 & 0 & 1502 \\
\hline 7302 LOUTSIANA GULFF & 1.496 & ( & 681 & & 0 & 8310 \\
\hline 9000 EXPOFT & 0 & C & 5208 & & 0 & 52083 \\
\hline TOTAL VOLUME & 8665 & $11.4:$ & 5942 & & 0 & 69235 \\
\hline
\end{tabular}

TABLE 209. 1977 COFN KECETFTS FFOM UAFIOUS OFIOINS BY FTRMS IN AREA 7.103, TOLELO AREA

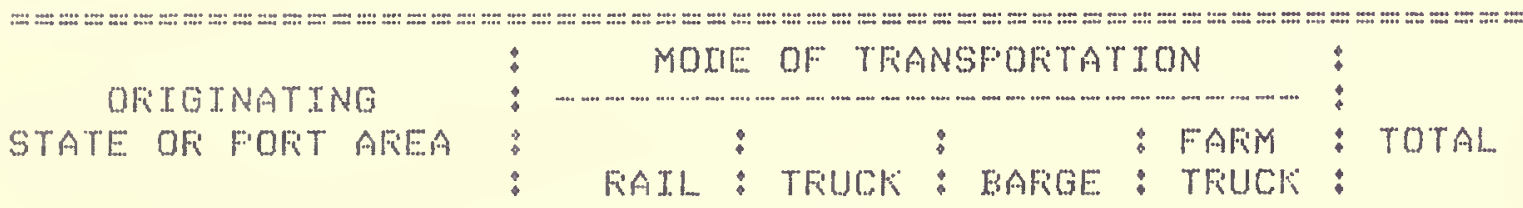

(THOUSANIS OF EUSHELS)

\begin{tabular}{|c|c|c|c|c|c|}
\hline 1825 OHIO & 18 in & 4634 & 0 & 0 & 4819 \\
\hline 1850 OHIO & 0 & 40800 & 0 & 3510 & 44310 \\
\hline 1901 INOIANA & 0 & 0 & 0 & 628 & 628 \\
\hline 1902 INIITANA & 0 & 7301 & 0 & 0 & 7301 \\
\hline 2000 MICHIGAN & 0 & 22720 & 0 & 5015 & 27735 \\
\hline
\end{tabular}


TALLE 210, $197 \%$ COFN SHTWMETS TO UARIOUS IESTTNATTONS EY

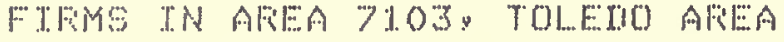

:

TESTINATTON

STATE OF FOFT AFEA
MOTE OF TFANSFORTATTON

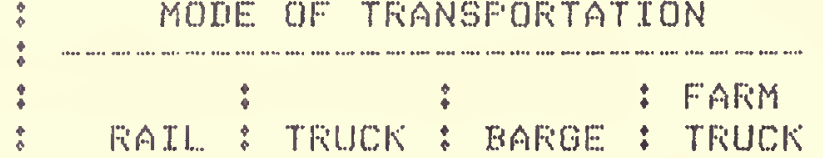

(TMOUSANRS OF BUSHELS)
9000 EXWOHT

TOTAL VOLUME
0

0

$0 \quad 84933$

$0 \quad 84933$

0

0

84933

$0 \quad 84933$

TABLE 211. 197\% COFN FECEFTS FROM UAFIOUS OFIGTNS BY FIVIS IN AREA 7104, SACINAW AREA

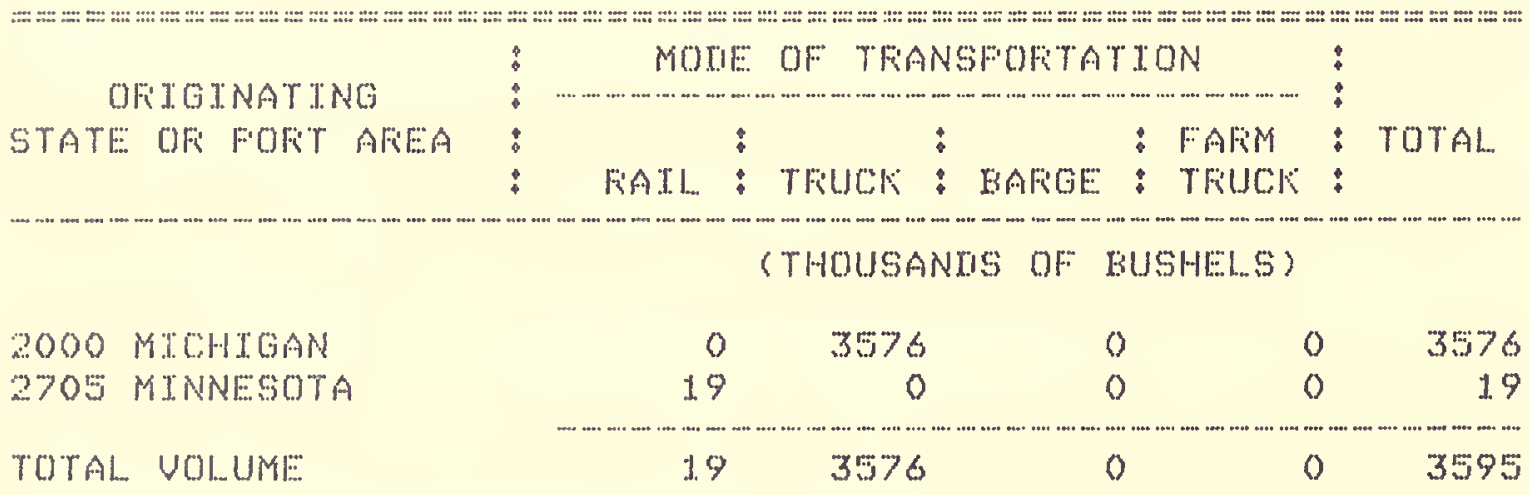

TABLE 2J2, 1977 COFN SHIFMENTS TO UAFIOUS IESTINATIONS RY FIFMS IN AREA 7104, SAGINAW AREA

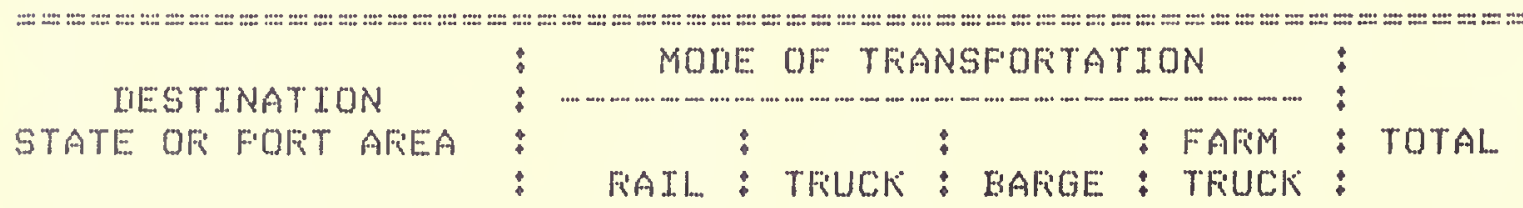

(THOUSANIIS OF EUSHELS)

9000 EXFOFT

$\begin{array}{ccccc}0 & 0 & 3576 & 0 & 3576 \\ 0 & 0 & 3576 & 0 & 3576\end{array}$

TOTAL VOLUME

(1)

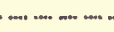


TABLE: 2.3. 1977 COFN FECETFTS FFOM UAFIOUS OFIGINS DY FIFMS TN AFEA 7201, NOFTH ATLANTTC

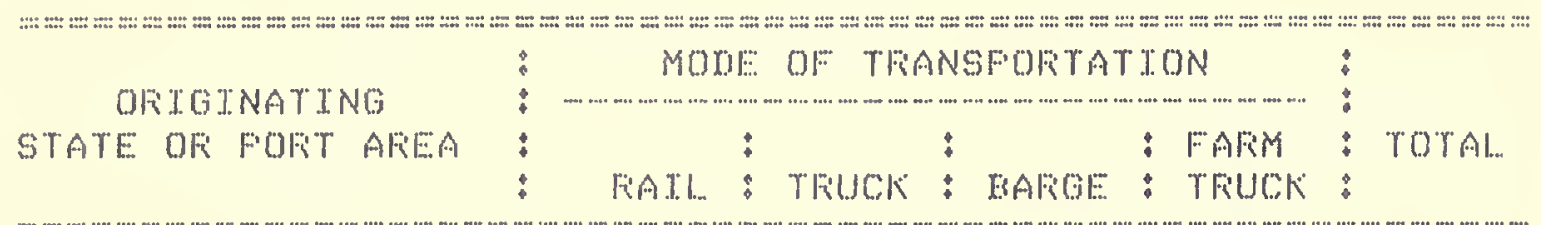

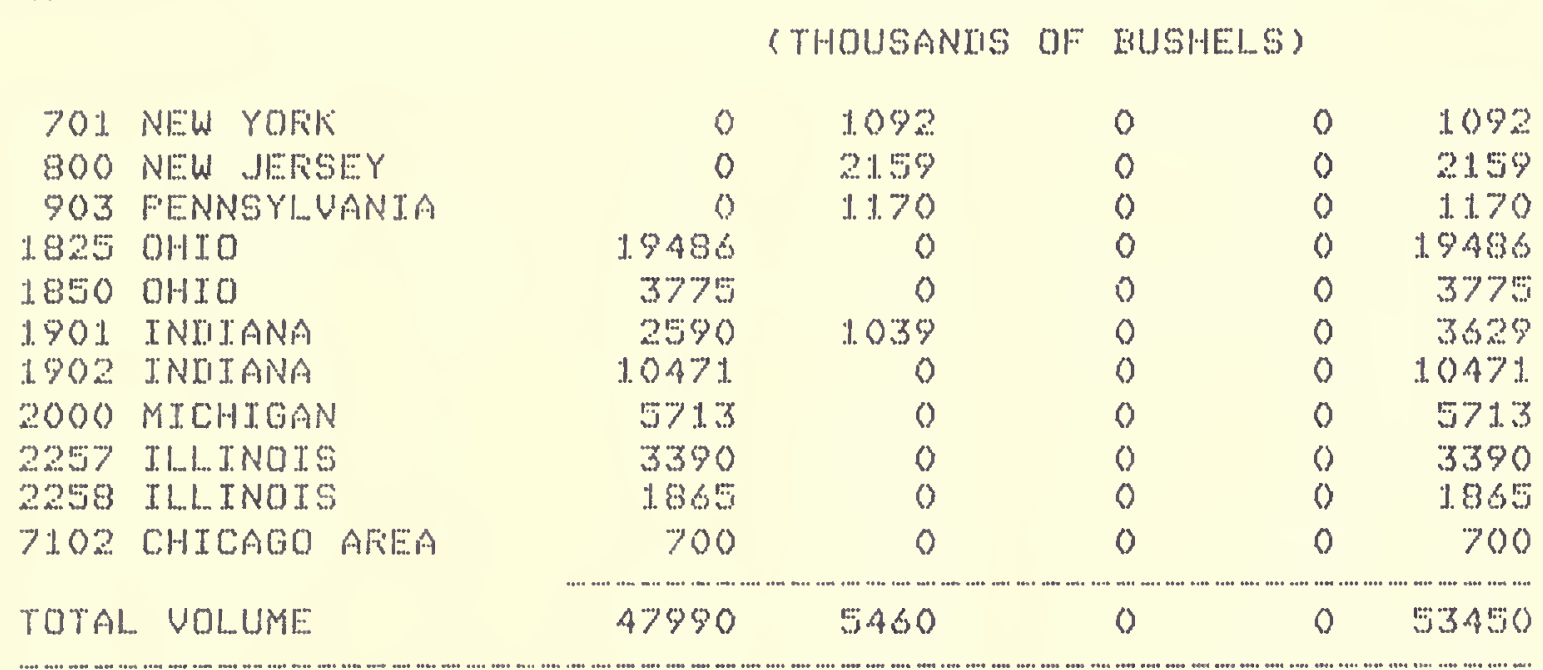

TALLE 21.4. 1977 COFN SHIFMENTS TO VAFTOUS DIESTINATIONS BY FIFIMS IN AFEA 7201. NOFTH ATLANTIC

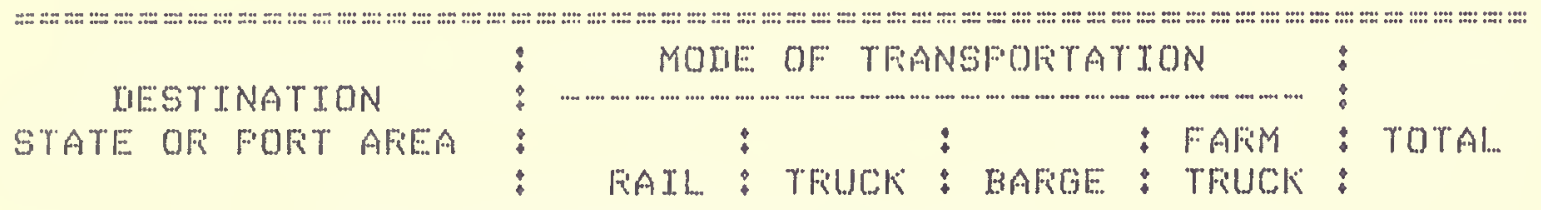

(THOUSANRS OF MUSHEISS)

$\begin{array}{lllccc}9000 \text { EXFOFT } & 0 & 0 & 56935 & 0 & 56935 \\ \text { TOTAL VOLUME } & 0 & 0 & 56935 & 0 & 56935\end{array}$


TABLE 215, 1977 COFN FECIIETS FFOM UAFIOUS OFTGINS BY FIEMS IN AFEA 7202, SOUTH ATI...ANTIC

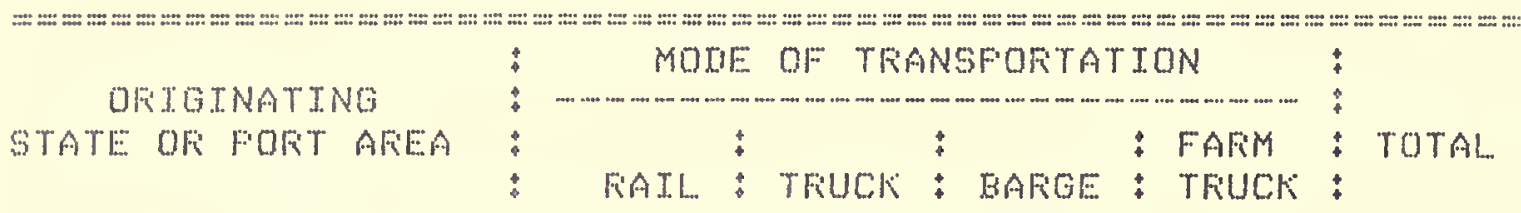

(THOUSANDIS OF EUSHELS)

903 FENNSYLUANTA

1000 DELAWWAFE

1100 MAFYLANI

1200 VIFGTNIA

1. 400 NOFTH CAFOLINA

1500 SOUTH CAROL JNA

1603 GEOFGTA

1825 OHTO

$1.8900 \% 100$

1901 J.NDI.ANA

1902 INIIANA

2000 MTCHITEAN

2257 TILI... TNOIS

220 TLLININOIS

7102 CHTCACO AREA

7202 SOUTH ATLANTIC

TOTAL.. VOL..UME

$\begin{array}{rrrrr}0 & 1197 & 0 & 0 & 1197 \\ 0 & 90 & 1307 & 0 & 1397 \\ 0 & 6605 & 71 & 1949 & 8625 \\ 0 & 0 & 1611 & 3623 & 5234 \\ 1904 & 16034 & 2348 & 0 & 20286 \\ 1129 & 3225 & 0 & 640 & 4999 \\ 0 & 215 & 0 & 0 & 215 \\ 49758 & 561 & 0 & 0 & 49319 \\ 42128 & 402 & 0 & 0 & 42530 \\ 44202 & 0 & 0 & 0 & 44202 \\ 105062 & 0 & 0 & 0 & 105062 \\ 1.4122 & 0 & 0 & 0 & 14122 \\ 18006 & 15 & 0 & 0 & 18021 \\ 12544 & 0 & 0 & 0 & 12544 \\ 1502 & 0 & 0 & 0 & 1502 \\ 0 & 95 & 0 & 0 & 95\end{array}$

28935728439

5337

6217

329350

TABLE 216.1977 COFN SHTFMENTS TO UAFITOUS IESTTNATTONS EY FIRMS IN AFEA 7202, SOUTH ATLANTIC

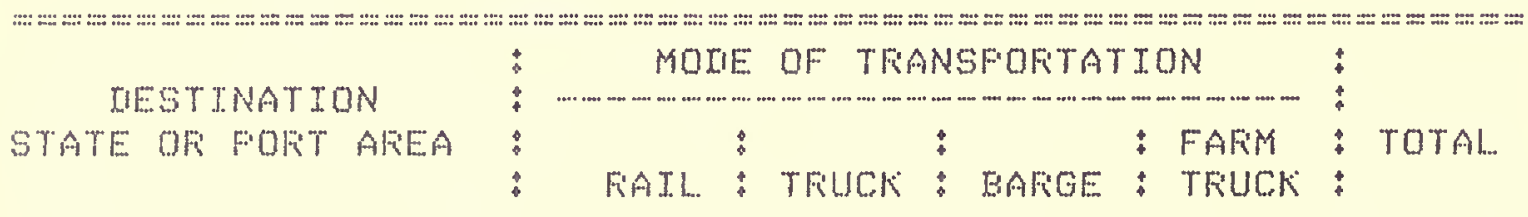

(THOUSANIS OF BUSHELS)

$\begin{array}{lrrrrr}903 \text { FENNGYLVANIA } & 0 & 194 & 0 & 0 & 194 \\ 1100 \text { MAFYLANI } & 0 & 81 & 118 & 0 & 199 \\ 1200 \text { VIFGINIA } & 0 & 221 & 359 & 0 & 580 \\ 1400 \text { NOFTH CARDI.INA } & 1423 & 1172 & 0 & 0 & 2595 \\ 7202 \text { SOUYH ATLANTTC } & 0 & 95 & 0 & 0 & 95 \\ 9000 \text { EXFOFT } & 0 & 0 & 273802 & 0 & 273802 \\ \text { TOTAL WOLUME } & 1.423 & 1763 & 274279 & 0 & 277465\end{array}$


TASLE 21\% 1977 COFN FECEIFTS FFOM UARIOUS ORTOINS BY

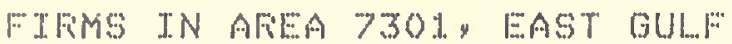

\begin{tabular}{|c|c|c|c|c|c|c|c|}
\hline \multirow{3}{*}{$\begin{array}{c}\text { OFICINATING } \\
\text { STATE OF FOHT AFEEA }\end{array}$} & \multirow{3}{*}{$\vdots$} & \multicolumn{2}{|c|}{ MOLE OF } & \multicolumn{2}{|c|}{ TFANSFOFTATION } & ; & \multirow{3}{*}{ TOTAL } \\
\hline & & : & 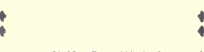 & $\vdots$ & : FAFM & : & \\
\hline & & FinJ.... & TFUCK & : BAFGE: & : TFUCK & : & \\
\hline & & \multicolumn{5}{|c|}{ (THOUSANIS OF BUSHELS) } & \\
\hline 1701 FI..OFInA & & 87 & 421 & 1.1 .7 & & 0 & 625 \\
\hline 1703 FLOFIIIA & & 564 & 0 & 0 & o & 0 & 56.4 \\
\hline 2256 ILIINOIS & & 0 & 0 & 300 & & 0 & 300 \\
\hline 2238 T.LI... INOTS & & 7650 & 0 & 0 & 0 & 0 & 7650 \\
\hline 2260 III... INOIS & & 0 & 0 & 2459 & & 0 & 2459 \\
\hline 2270 TLLINOIS & & 0 & 403 & 0 & 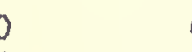 & 0 & 403 \\
\hline OZ1.8 KENTUCKY & & 0 & 0 & 626 & & 0 & 626 \\
\hline 2319 KEENTUCKY & & 2503 & 0 & 0 & 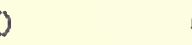 & 0 & 2503 \\
\hline 2503 MTSSTSSTFFT & & 0 & 216 & 0 & ) & 0 & 216 \\
\hline 2607 ALAFAMA & & 0 & 1.061 & 2.381 & 10 & & 3542 \\
\hline 2703 MINNESOTA & & 25 & 0 & 0 & ) & 0 & 25 \\
\hline 2705 MINNESOTA & & 0 & 0 & 1.96 & & 0 & 196 \\
\hline 2801 IOWA & & 308 & 0 & 0 & ) & 0 & 308 \\
\hline $2802 \quad 10 W A$ & & 267 & 0 & 0 & 0 & 0 & 267 \\
\hline 2900 MISSOUFT & & 0 & 0 & 1000 & & 0 & 1000 \\
\hline 3404 NEWHASKKA & & 135 & 0 & 0 & 0 & 0 & 135 \\
\hline 3AOS NEEIIASKIA & & 45 & 0 & 0 & 0 & 0 & 45 \\
\hline 3503 K゙ANSAS & & 120 & 0 & 0 & 0 & 0 & 120 \\
\hline TOTAL VOI...UME:. & & 11704 & 2101 & 7079 & 10 & & 20984 \\
\hline
\end{tabular}

TABLE 218. 1977 COFN SHIFMENTS TO VAFTOUS IESTINATIONS EY FIFIMS IN AFEEA 7301, EAST GULF

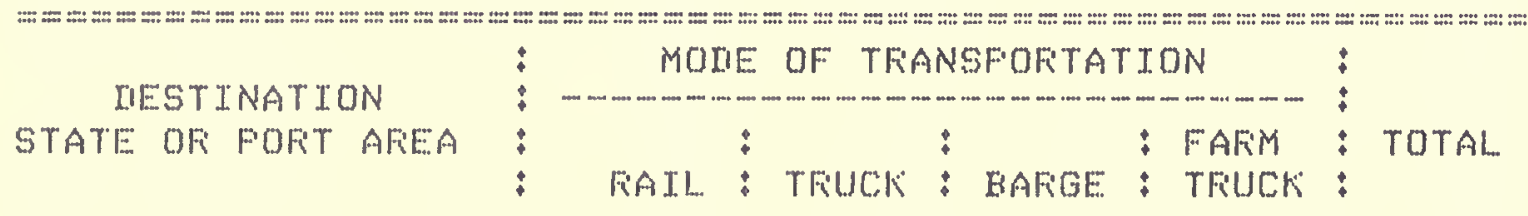

(THOUSANIS OF RUSHELS)

9000 EXFOFIT

$0 \quad 0 \quad 22320 \quad 0 \quad 22320$

TOTAL VOL.UME

$\begin{array}{ccccc}0 & 0 & 22320 & 0 & 22320 \\ -0 & 0 & 22320 & 0 & 22320\end{array}$


TAELE 219, 1977 COFIN FECEIFTS FFOM UARTOUS OFIGINS EY FTRMS TN AREA 7302, LOUTSIANA GULF

\begin{tabular}{|c|c|c|c|c|}
\hline & MOIIE: & TFANSFOFTAY & $\mathrm{TON}$ & : \\
\hline OFIGTNATTNG & 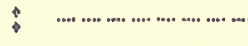 & (ב. & (n) & $:$ \\
\hline STATE OFI FOFT AFEA & RAIL. & TFUCK： BAFGE & $\begin{array}{l}\text { : FAFIM } \\
\text { :FFUCK }\end{array}$ & rotAl. \\
\hline
\end{tabular}

\begin{tabular}{|c|c|c|c|c|c|c|}
\hline \multirow[b]{2}{*}{1825} & \multirow[b]{2}{*}{ OHIO } & \multicolumn{5}{|c|}{ (THOUSANES OF BUSHELS } \\
\hline & & 0 & 0 & 28230 & 0 & 28230 \\
\hline 1.901 & INIIIANA & 271.2 & 0 & 0 & 0 & 2712 \\
\hline 1902 & INDIANA & 1.457 & 0 & 0 & 0 & 1457 \\
\hline 190.3 & TNIITANA & 234 & 0 & 10790 & 0 & 1.6024 \\
\hline 2103 & WTSCONSTN & 0 & 0 & 3350 & 0 & 3350 \\
\hline 2256 & TLI JNOIS & 0 & 0 & 2281.83 & 0 & 2281.85 \\
\hline 2057 & ILLINOIS & 46935 & 0 & 0 & 0 & 46935 \\
\hline 2258 & I.LINNOTS & $2386 \%$ & 0 & 0 & 0 & 23867 \\
\hline 2259 & J.LLINOIS & 0 & 0 & 7391 & 0 & $739 \%$ \\
\hline 2260 & ILLINOIS & 1086 & 0 & 203068 & 0 & 204154 \\
\hline 2261 & II..... TNOIS & 0 & 0 & 41624 & 0 & 41624 \\
\hline 2262 & TLLTNOIS & 3704 & 0 & 17684 & 0 & 21388 \\
\hline 2270 & TLLINOIS & 1.326 & 0 & 0 & 0 & 1. 1526 \\
\hline 2318 & KEENTUCKY & 0 & 0 & 38000 & 0 & 38000 \\
\hline 2319 & KENTUCKY & 0 & 0 & 5640 & 0 & 5640 \\
\hline 2412 & TENNESSEE & 0 & 0 & 2231 & 0 & 2231 \\
\hline 2704 & MINNESOTA & 20772 & 0 & 0 & 0 & 20772 \\
\hline 2705 & MINNESOTA & $68 \%$ & 0 & 75388 & 0 & 76085 \\
\hline 2801 & IOWA & 25314 & 0 & 2760 & 0 & 28074 \\
\hline 2802 & IOWA & 10235 & 0 & 0 & 0 & 10255 \\
\hline 2803 & IOWA & 768 & 0 & 1153689 & 0 & 154457 \\
\hline 2800 & MISSOUFI & 33 & 0 & 27450 & 0 & 27003 \\
\hline 3100 & LOUISTANA & 0 & .1. 80 & 0 & 0 & .180 \\
\hline 3404 & NEEFAASKA & 611 & 0 & 0 & 0 & 611 \\
\hline 3405 & NEEFIASKKA & 0 & 0 & 1825 & 0 & 1825 \\
\hline 3503 & KANSAS & 1644 & 0 & 0 & 0 & 1644 \\
\hline 3505 & KIANSAS & 132 & 0 & 0 & 0 & 132 \\
\hline 7102 & CHICAGO AFEA & 1.496 & 0 & 6814 & 0 & 8310 \\
\hline
\end{tabular}


TABLE 220. 1977 COFN SHIFMENTS TO UAFIOUS [IESTTNATIONS EY FIFMS IN AFEA 7302, LOUISIANA GULF

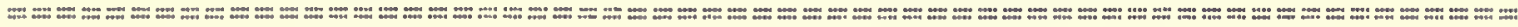

DESTINATION

STATE OFI FOFIT AFEA

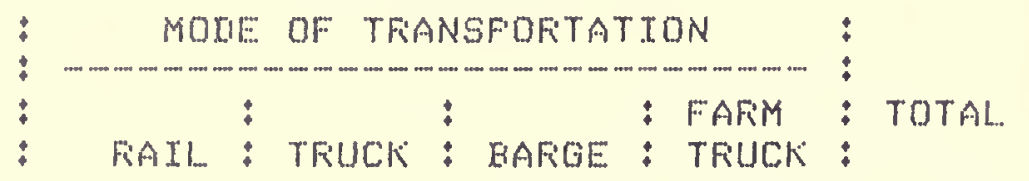

(THOUSANXS OF BUSHELS)
1705 FLOKIIAA

2502 MISSISSTFFI

2503 MISSISSIFFI

3100 LOUISIANA

9000 EXFOFTT
0

624

0

0

0

50

0

0

0

0

50

112

1.764

0

624

112

1764

0

0

953982

TOTAL VOLUME

953982

0

624

$1876 \quad 954032$

$0 \quad 956532$

TABLE: 221. 1977 COFN RECETFTS FFOM VARTOUS ORTGINS BY FTRMS IN AFEA 7303 Y NO. TEXAS GULF

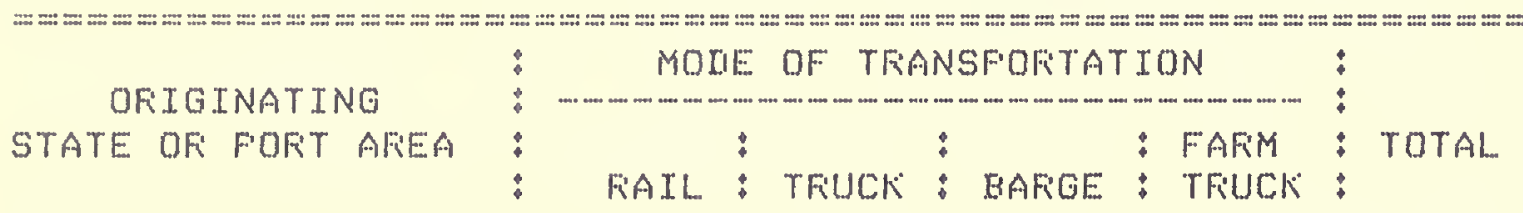

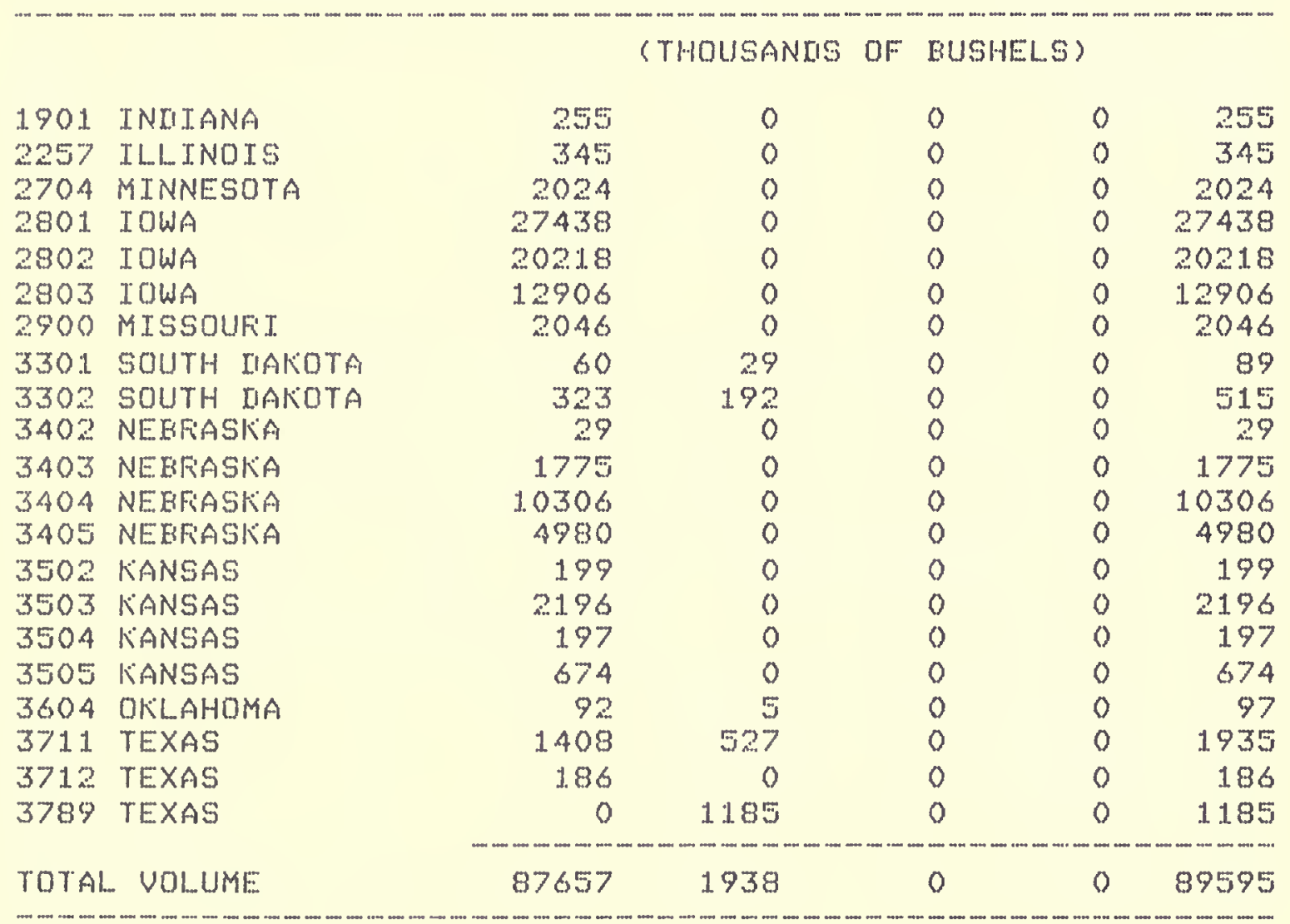


TABLE 222, $197 \%$ COFN SHIFHENTS TO UAFTOUS DESTINATIONS BY FRMS IN AFIEA 7303, NO. TEXAS GULF

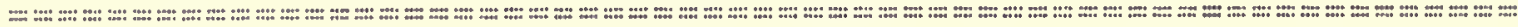

MESTINATION

GTATE: OR FOFT ARE:

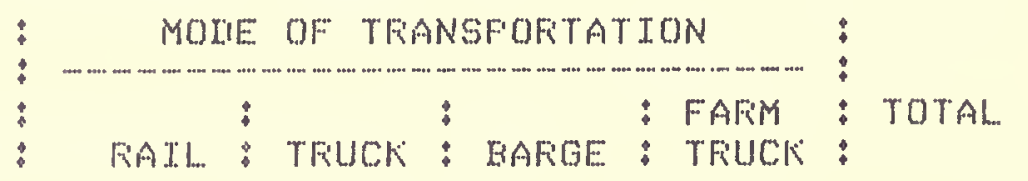

(THOUSANDS OF BUSHELS)
9000 EXFOFT

TOTAL. VOL.UME

$\begin{array}{ccccc}0 & 0 & 91908 & 0 & 91908 \\ 0 & 0 & 91908 & 0 & 91908\end{array}$

TABLE: 223. $197 \%$ COFN FECETFTS FFOM UARTOUS OFIGINS BY FIFMS IN AFEA 7304y SO. TEXAS GULF

OFTGINATING
STATE OF FOFT AFIEA

(THOUSANIS OF BUSHELS)

3404 NEEFIASKA

3405 NEEFASKIA

3503 バANSAS

3789 TEXAS

TOTAL VOI...UME

$\begin{array}{rrrrr}9 & 0 & 0 & 0 & 9 \\ 20 & 0 & 0 & 0 & 20 \\ 01 & 0 & 0 & 0 & 501 \\ 0 & 125 & 0 & 0 & 125\end{array}$

TABLE 224, 1977 COFIN FECETFTS FFOM UAFIOUS OFTGINS BY FIFMS TN AFEA 7401, COLUMEIA FITUEF

\begin{tabular}{|c|c|c|c|c|}
\hline OKIGINATING & : MOIIE & OF TFANSFOFTAT & ION & \\
\hline STATE OF FOFT AFEA & FIAIL & TFUUCK : BAFGE & $\begin{array}{l}\text { : FARM } \\
\text { : TFUCK }\end{array}$ & TOTAL \\
\hline
\end{tabular}

(THOUSANLIS OF EUSHELS)

3301 SOUTH IIAKOTA

3401 NEBFASKKA

3404 NEEFASSKA

3405 NEBFIASKKA
530

125

0

0

\begin{tabular}{rrrrr}
322 & 0 & 0 & 0 & 322 \\
38 & 0 & 0 & 0 & 38 \\
2111 & 0 & 0 & 0 & 2111 \\
412 & 0 & 0 & 0 & 412 \\
\hline 2883 & 0 & 0 & 0 & 2883
\end{tabular}


TABLE 225. 1977 COFN SHIFMENTS TO UAFIOUS DESTTNATIONS BY FIFMS IN AFEA 7401, COLLMEIA FITUEF

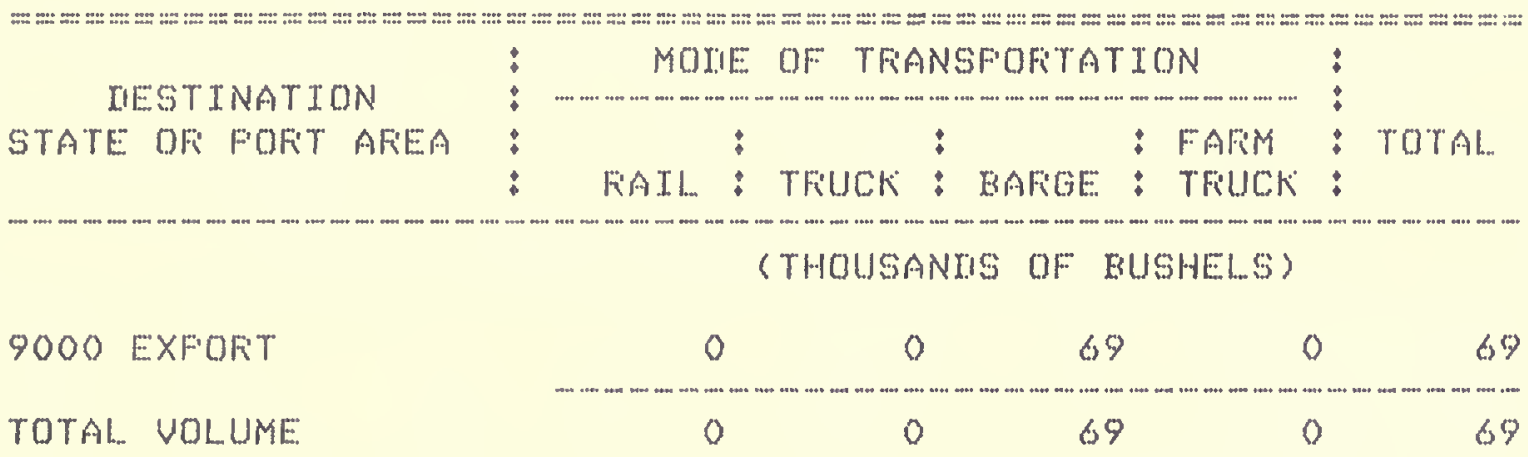

TABLE 226. 1.977 COFN FECETFTS FFOM UAFIOUS OFIGINS EY FIFMS IN AFIEA 7402, FUGET SOUNI

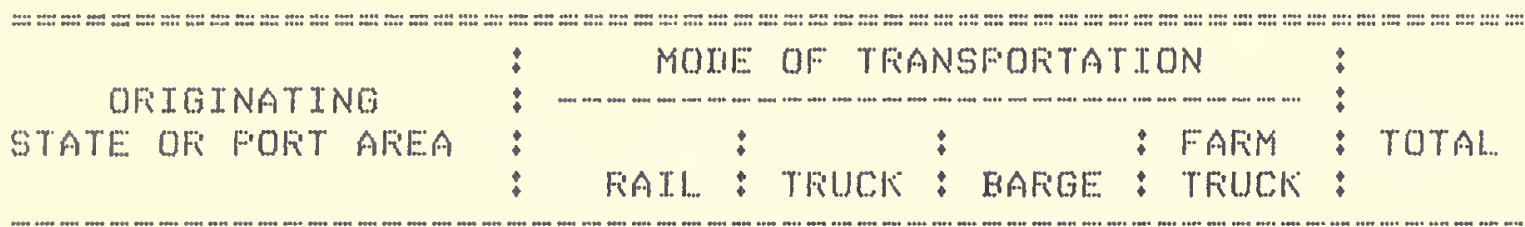

2801 IOWA

3302 SOUTH RAKOOTA

3404 NERFIASKA

3405 NEEFIASKIA

TOTAL VOLUME

(2)

\section{(THOUSANIIS OF EUUSHELSS}

\begin{tabular}{rcccc}
4388 & 0 & 0 & 0 & 4388 \\
136 & 0 & 0 & 0 & 136 \\
3532 & 0 & 0 & 0 & 3532 \\
421 & 0 & 0 & 0 & 421 \\
\hline 3477 & 0 & 0 & 0 & 8477
\end{tabular}

TARLE 227. 1977 COFN SHIFMENTS TO UAFIOUS UESTINATIONS RY FIFIMS IN AFEA 7AO2, FUGET SOUNI

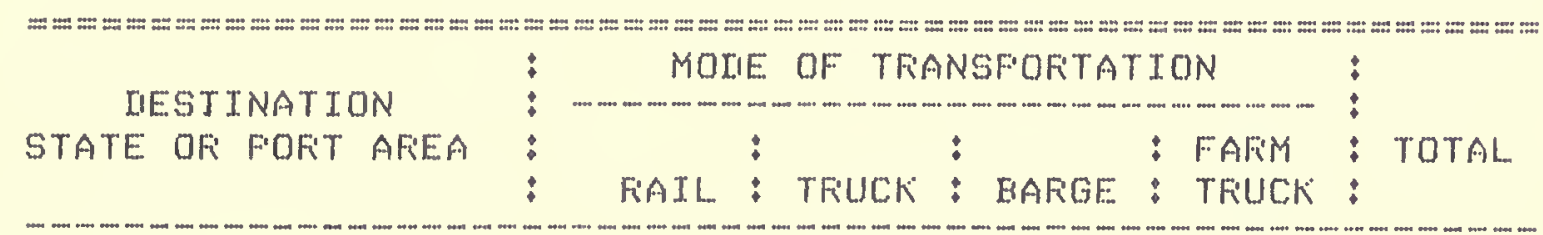

(THOUSANIIS OF EUSHELS)

9000 EXFGFT

TOTAL VOLUME

\begin{tabular}{ccccc}
0 & 0 & 18 & 0 & 18 \\
\hline 0 & 0 & 18 & 0 & 18
\end{tabular}


TARLE 228, 1977 CORN FECEIFTS FFOM UAFIOUS ORIGINS BY FIFMS IN AFEA 74OZ, CALIFERNIA

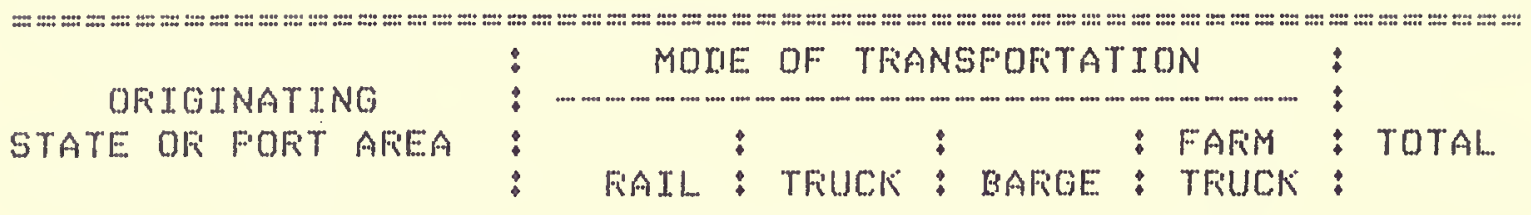

(THOUSANDS OF BUSHELS)

$\begin{array}{lrrrrr}3404 \text { NEEFIASKA } & 9708 & 0 & 0 & 0 & 9708 \\ 3405 \text { NEBFASKIA } & 5 \% 1 & 0 & 0 & 0 & 551 \\ 3504 \text { KANSAS } & 24 & 0 & 0 & 0 & 24 \\ 3505 \text { KKANSAS } & 68 & 0 & 0 & 0 & 68 \\ 4703 \text { CALIFOFNIA } & 0 & 429 & 0 & 5275 & 5704 \\ \text { TOTAL VOLUME } & 10351 & 429 & 0 & 5275 & 16055\end{array}$

TABLE 229. 1977 COFN SHIFMENTS TO UAFIOUS DIESTINATIONS BY FTFMS IN AFEA 7403, CALIFOFNIA

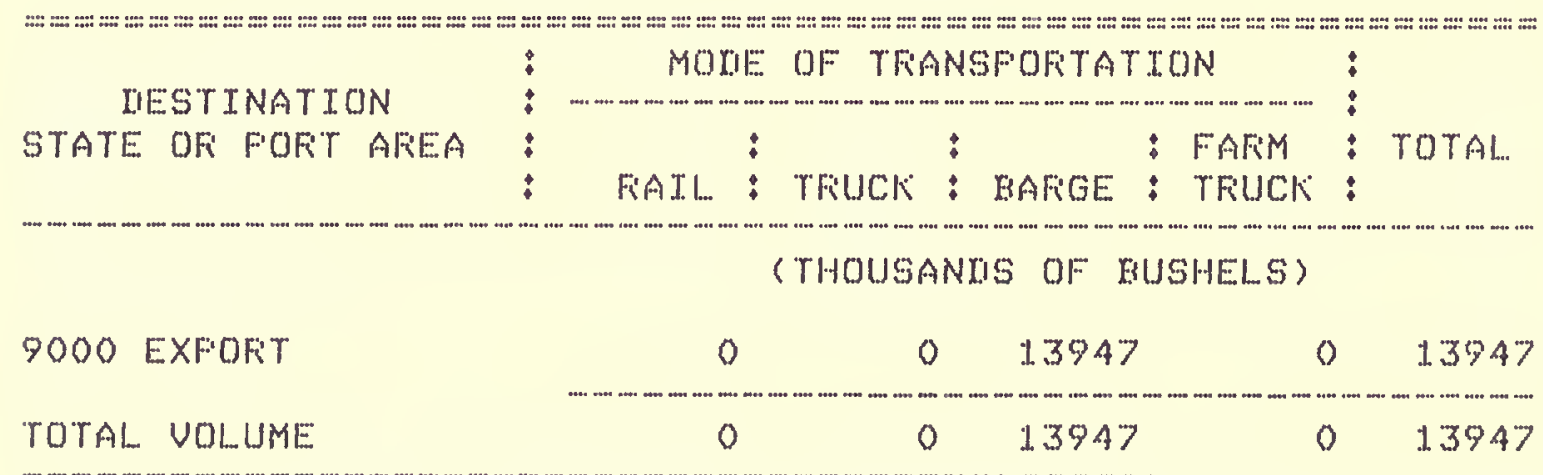






